Série Ensino, Aprendizagem e Tecnologias

\title{
Educação em Direitos Humanos
}

Rochele Fellini Fachinetto

Fernando Seffner

Renan Bulsing dos Santos

Organizadores

\section{2a edição}

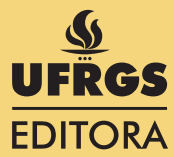




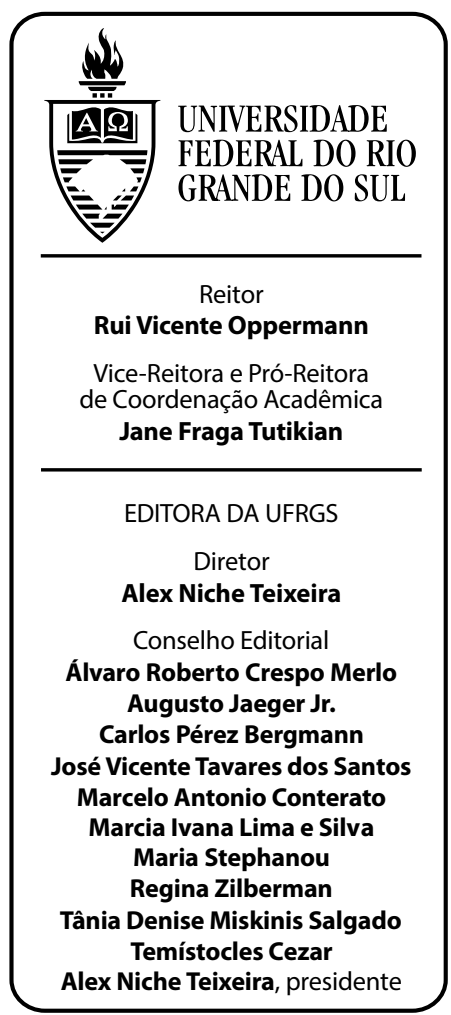




\section{Educação em Direitos Humanos}

Rochele Fellini Fachinetto Fernando Seffner Renan Bulsing dos Santos

Organizadores

2a edição

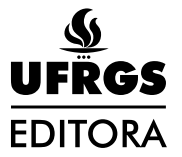


(C) dos autores

$1^{\text {a }}$ edição 2017

Direitos reservados desta edição:

Universidade Federal do Rio Grande do Sul

Coordenação da Série:

Laura Wunsch, Cínthia Kulpa, Tanara Forte Furtado e Marcello Ferreira

Coordenação de Editoração: Cínthia Kulpa e Ely Petry

Capa: Ely Petry

Editoração Eletrônica: Bruno Assis, Ellen Rosa, Francine Aires

Revisores da $1^{\text {a }}$ edição: Carolina Rodrigues e Moira Revisões

Esta obra é resultante do Curso de Aperfeiçoamento Educação em Direitos Humanos, financiado pelo Ministério de Educação (MEC) e Fundo Nacional de Desenvolvimento da Educação (FNDE) e ofertado pela Universidade Federal do Rio Grande do Sul (UFRGS) através do Centro de Formação de Professores (FORPROF) no ano de 2014.

O presente trabalho foi realizado com apoio da Coordenação de Aperfeiçoamento de Pessoal de Nível Superior - Brasil (CAPES) - Código de Financiamento 001.

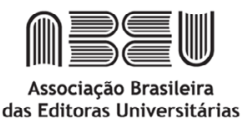

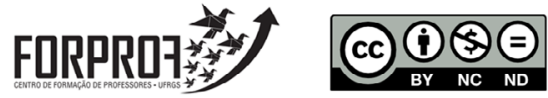

E24 Educação em Direitos Humanos [ recurso eletrônico] / organizadoras Rochele Fellini Fachinetto, Fernando Seffner [e] Renan Bulsing dos Santos ; coordenado pela SEAD/UFRGS. - 2. ed. - dados eletrônicos. - Porto Alegre: Editora da UFRGS, 2018.

254 p. ; pdf

(Série Ensino, Aprendizagem e Tecnologias)

Inclui referências.

1. Educação. 2. Direitos Humanos. 3. Cidadania. 4. Violência - Espaço escolar. 5. Conflitos - Cotidiano escolar. 6. Prática docente - Direitos Humanos. 7. Gênero - Escola - Democracia. 8. Dominação masculina. 9. Sexualidade - Juventude. I. Fachinetto, Rochele Fellini. II. Seffner, Fernando. III. Santos, Renan Bulsing dos. IV. Universidade Federal do Rio Grande do Sul. Secretaria de Educação a Distância. V. Série.

CDU 37:342.7

CIP-Brasil. Dados Internacionais de Catalogação na Publicação.

(Jaqueline Trombin- Bibliotecária responsável CRB10/979)

ISBN 978-85-386-0444-0 


\section{ADVERTÊNCIA}

Uma das principais preocupações deste trabalho é o uso de linguagem inclusiva de gênero. Porém, com o intuito de preservar a fluidez da leitura e evitar sobrecarga gráfica, optou-se pelo emprego do masculino genérico, quando não especificada a diferenciação de gênero. Os trechos em itálico reproduzem falas de estudantes, profissionais da educação e responsáveis, aqui apresentadas conforme a expressão de seus autores no momento das entrevistas.

\section{AGRADECIMENTOS}

Agradecemos ao empenho dos docentes, tutores e tutoras, coordenação, pessoal técnico administrativo da UFRGS, do MEC e dos quatro polos abrangidos pela Secretaria de Educação à Distância da UFRGS: Porto Alegre, Santo Antônio da Patrulha, São Francisco de Paula e Sapucaia do Sul, que tornaram possível a realização do curso de aperfeiçoamento em regime EAD Educação em Direitos Humanos, do qual resultou este livro. Em especial agradecemos aos cursistas, professores e professoras do ensino fundamental e ensino médio dos quatro municípios, que se dispuseram a rever suas práticas, a enfrentar delicadas questões de respeito à diferença no âmbito da docência e a modificar os regimes escolares, possibilitando abertura para novos caminhos pedagógicos pautados nos direitos humanos. 



\section{SUMÁRIO}

\section{Capítulo 1}

EDUCAÇÃO EM DIREITOS HUMANOS: COMPONENTE CURRICULAR INDISPENSÁVEL NA ESCOLA PÚBLICA BRASILEIRA CONTEMPORÂNEA .................................................. 9

Rochele Fellini Fachinetto, Fernando Seffner, Renan Bulsing dos Santos

\section{Capítulo 2}

DIREITOS HUMANOS: TUDO A VER COM A NOSSA VIDA 27

Paulo César Carbonari

\section{Capítulo 3}

CIDADANIA E DIREITOS HUMANOS: PARA TODOS

OU PARA ALGUNS?

Denise Dourado Dora

\section{Capítulo 4}

VIOLÊNCIAS E CONFLITUALIDADES

NO ESPAÇO ESCOLAR

Rochele Fellini Fachinetto

\section{Capítulo 5}

O COTIDIANO ESCOLAR COMO UM AMBIENTE

DE CONFLITOS E OS DIREITOS HUMANOS

COMO ESTÍMULO À SUA SOLUÇÃO PACÍFICA

.77

Renan Bulsing dos Santos

\section{Capítulo 6}

O INCREMENTO DA PRÁTICA DOCENTE A PARTIR

DA EXPERIÊNCIA DA TUTORIA PRESENCIAL:

PERCURSO DE (RE)SENSIBILIZAÇÃO ATRAVÉS

DA TEMÁTICA DOS DIREITOS HUMMANOS 
8. Capítulo 7

GÊNERO NA ESCOLA E DEMOCRACIA À BRASILEIRA:

LIMITES E DESAFIOS PARA UMA VIDA LIVRE

DE DISCRIMINAÇÃO E VIOLÊNCIA ..............................................103

Fabiane Simioni

\section{capítulo 8}

DOMINAÇÃO MASCULINA: A VIOLÊNCIA SIMBÓLICA NOSSA DE CADA DIA

Elisa Girotti Celmer

\section{Capítulo 9}

SEXUALIDADE E JUVENTUDE: PEGAR, FICARE NAMORO

Paula Pinhal de Carlos

\section{Capítulo 10}

EDUCAÇÃO PARA A SEXUALIDADE,

EQUIDADE DE GÊNERO E DIVERSIDADE SEXUAL:

APONTAMENTOS PARA FORMAÇÃO

DE PROFESSORES(AS) DA EDUÇCÇÃO BÁSICA

Alessandra Maria Bohm

\section{Capítulo 11}

EDUCAÇÃO A DISTÂNCIA: UMA FERRAMENTA

POSSÍVEL DE INCLUSÃO E REINSERÇÃO DE LGBTS

AO ESPAÇO EDUCACIONAL

175

Amilton Gustavo da Silva Passos

\section{Capítulo 12}

QUANDO AIDS, GÊNERO, SEXUALIDADE E DIREITOS

HUMANOS SE ENCONTRAM NO TERRITÓRIO ESCOLAR

Cláudio Nunes, Fernando Seffner

RESUMOS DOS TRABALHOS FINAIS DOS ALUNOS 207 


\section{EDUCAÇÃO EM DIREITOS HUMANOS: COMPONENTE CURRICULAR INDISPENSÁVEL NA ESCOLA PÚBLICA BRASILEIRA CONTEMPORÂNEA}

Rochele Fellini Fachinetto

Fernando Seffner

Renan Bulsing dos Santos

\section{NÃO SE TRATA DE MAIS UM MODISMO EDUCACIONAL}

Desde a promulgação da Constituição Brasileira de 1988, que estabeleceu a obrigatoriedade da escolarização no ensino fundamental, a escola pública brasileira passou não apenas por um forte processo de inclusão (materializada no slogan e no programa "todos na escola") como também tem sido assolada por uma avalanche de temas que se entendeu que ela deveria tratar. Câmaras de vereadores, assembleias legislativas, câmara federal, conselhos de educação e diretivas do executivo propuseram à escola a abordagem de educação sexual, educação para a paz, educação para o trânsito, noções do código do consumidor, direitos da criança e do adolescente, educação estética e musical, conhecimento de línguas estrangeiras para além do inglês, ensino religioso, preparação para o trabalho, educação ambiental, multiculturalismo, educação antirracista, ética e cidadania, educação para a saúde, educação para as competências e habilidades, conhecimentos 
e práticas da alimentação saudável, dentre outros temas de caráter mais episódico e pontual. Muitas vezes, delegar à escola o ensino de certos temas representa certa incompetência de outros órgãos e instâncias sociais que não têm sucesso em sua missão educativa e acabam por enxergar na escola a alternativa para efetivar o que não conseguem fazer. $\mathrm{O}$ ingresso dessa avalanche de conteúdos e questões na estrutura curricular tem se dado basicamente através de três formas: na criação de novas disciplinas (ensino religioso, ética e cidadania, educação para o trânsito, por exemplo); na abordagem via temas transversais dentro das disciplinas (educação sexual; educação para a paz; abordagens do multiculturalismo, por exemplo) ou na execução de projetos interdisciplinares com duração temporal variável e agregando certo número de disciplinas (educação antirracista, educação ambiental, conhecimentos e práticas da alimentação saudável, por exemplo).

Este movimento de delegar à escola uma série de novos conteúdos e funções deriva de uma conexão entre vários fatores: ampliação e aprofundamento do regime democrático brasileiro; a intensificação das lutas políticas e pelos direitos de comunidades e atores sociais; a inclusão obrigatória de todos e todas na escola de ensino fundamental; a ampliação da oferta de ensino médio tanto pelo acesso dos jovens quanto pelo retorno aos bancos escolares de indivíduos que haviam se evadido; o crescimento do acesso ao ensino superior; o ingresso na escola de grupos sociais marginalizados; o crescimento da oferta de escolas públicas em regime de turno integral, com a consequente ampliação do horário de cobertura escolar; a abertura das escolas aos finais de semana, através do Programa Mais Educação ${ }^{1}$ e de outras iniciativas, funcionando como locais de agregação e convívio das culturas juvenis. A forte ampliação da presença da rede escolar no Brasil em todo o território nacional se conjuga com demandas de integração e inclusão social que todas elas passam pela necessidade de formação escolar. Ir à escola não é mais algo opcional, é agora obrigatório por lei e exigência indispensável para inserção no mundo do trabalho e na sociedade do conhecimento e da informação.

1 Mais informações em: < http://portal.mec.gov.br/programa-mais-educacao > . Acesso em: out. 2015. 
Todo este conjunto de pressões afeta a escola, os gestores dos sistemas de ensino, os alunos e alunas, pais e famílias e principalmente professores e professoras, que têm estado no centro de intermináveis debates sobre quais conteúdos devem ser ensinados e quais os modos mais adequados de ensinar e se são competentes ou não para o exercício da docência. A isso, somaramse pelo menos dois outros fatores de estresse educacional: o primeiro são os exames e avaliações nacionais e internacionais rotineiros, que mensuram as competências, os conhecimentos e as habilidades do alunado, oportunizando comparações entre turmas de alunos, entre escolas e grupos de escolas, entre redes escolares de diferentes entes federativos, entre países e continentes, e gerando um impacto sem precedentes na mídia nacional, que deles se ocupa de modo insistente e em tom francamente alarmista. O segundo fator de estresse são as polêmicas acerca do financiamento da educação pública, que envolve gastos que vão da merenda escolar até a aquisição de equipamentos de informática, passando pelo transporte dos alunos, aquisição massiva de livros didáticos, ampliação de prédios, construção de quadras esportivas, dentre outras rubricas.

É necessário reconhecer que nas últimas décadas a profissão docente tem enfrentado desafios enormes, que vão desde os baixos salários, passando pela exigência de novos conhecimentos e chegando até a necessidade de gerência das situações de indisciplina e violência entre alunos e aquelas dirigidas aos próprios docentes, que são rotineiras nos espaços escolares no Brasil e no mundo; basta um exame aos noticiários diários. É nesse contexto que tem avançado a demanda por oportunidades de formação continuada para professores e professoras, feita pelos próprios docentes e por suas associações. Claro está que a formação continuada não vai resolver todos os problemas apontados acima, vários dos quais são decisões de gestores, mas ela pode colaborar para ampliar as oportunidades pedagógicas em sala de aula. Não é mais possível permanecer em atividade na sala de aula apenas com o que foi aprendido na formação inicial nas licenciaturas. É necessário ter espaços de aprendizagem constante para os professores acerca das culturas juvenis, dos impasses políticos da educação nacional, das novas teorias e métodos de ensino e aprendizagem, dos novos conteúdos 
e temas transversais, das possibilidades tecnológicas que se abrem a todo instante no cenário educacional. O dinamismo do sistema educacional, com a incorporação dos novos conhecimentos, efetivamente implica oportunizar aos professores boas condições de formação continuada.

No meio dessa realidade altamente dinâmica e cheia de conflitos e enfrentamentos entre os diferentes modos de conceber a natureza e funções da educação pública nacional, o objetivo deste texto é analisar a necessidade e importância da presença da Educação em Direitos Humanos na escola pública brasileira. Não se trata de inserir mais um componente, mas de agregar diversos conteúdos, objetivos e estratégias educacionais e políticas já presentes no ambiente escolar no interior de uma robusta preocupação com os direitos humanos. Para compreender a importância da Educação em Direitos Humanos na escola pública brasileira, é necessário discutir a função e propósitos que a escola assume na contemporaneidade e detalhar a nova feição de sua figura central, a saber, o corpo de professores e professoras, bem como conhecer a natureza do campo dos direitos humanos e o ordenamento jurídico que estabelece a obrigatoriedade de seu ensino em todos os níveis e graus de escolaridade no país. Nos tópicos seguintes abordamos estes itens e no final do texto apresentamos os artigos que compõem este livro, produto final de um curso para professores e professoras em Educação em Direitos Humanos. Mostramos também algo da estruturação e funcionamento do curso, o que permite perceber melhor nossa compreensão de como se organiza o campo dos direitos humanos.

\section{ESCOLA PÚBLICA E PROFESSOR PÚBLICO NO CENÁRIO POLITICO ATUAL ${ }^{2}$}

A função social da escola pública experimentou variações ao longo das diferentes conjunturas históricas nacionais, com reflexos nas disciplinas e no ordenamento curricular. Nenhuma instituição atravessa a história sem

\footnotetext{
2 A exposição de motivos feita neste item está mais bem desenvolvida no artigo "Escola pública e professor como adulto de referência: indispensáveis em qualquer projeto de nação", de autoria de Fernando Seffner, em fase de publicação na Revista Educação Unisinos. Disponível em: http://revistas.unisinos.br/index.php/educacao/index> .
} 
experimentar modificações, o que afeta também a representação de seus integrantes frente à sociedade. No cenário político atual, a escola pública brasileira pode ser mais bem compreendida quando tomada em dupla função: a tradicional tarefa de instituição para aquisição do conhecimento científico acrescida fortemente de local onde jogam importante papel os processos de sociabilidade e socialização. Frente à comunidade de pais e famílias, bem como sociedade em geral, a escola retira boa parte da legitimidade social pela função de alfabetização científica. Em outras palavras, para isso que a ela são encaminhadas as novas gerações, para aprender a ler, escrever, interpretar, realizar as operações matemáticas, conhecer os conteúdos fundamentais da história e da geografia do país e do mundo, dominar uma língua estrangeira, ter contato com as artes, com as novidades tecnológicas e desenvolver habilidades esportivas.

Embora todos admitam que o conhecimento hoje se encontra disseminado no mundo virtual, havendo mesmo quem defenda a tese de que uma criança deixada na frente de um computador conectado à web poderá aprender mais e melhor do que na escola, pais e famílias ainda percebem a escola como o melhor local para a aprendizagem. É visível, entretanto, que na sociedade atual o pressuposto de que "os mais velhos educam os mais jovens" se encontra fortemente sacudido e quando se trata do domínio de tecnologias de informação e comunicação parece haver amplo consenso de que são os mais jovens que ensinam os mais velhos. Todas essas constatações abalam de certa forma o prestígio da escola, mas claramente a sociedade ainda não inventou outra instituição capaz de educar as novas gerações e a escola segue com sua tarefa de acesso ao conhecimento, embora com o reconhecimento de que ela necessita se atualizar, o que é dito de modo constante por muitos e diferentes atores sociais.

Se por um lado se pede que a escola se atualize, a força da tradição indica que há um conjunto de procedimentos altamente valorizados para aquisição do conhecimento e que marcam o cotidiano escolar, dentre eles: as novas gerações precisam aprender a disciplina da leitura e interpretação de textos. A busca do conhecimento científico se dá via pesquisas e coleta de informações; é importante aprimorar o registro escrito dos aprendizados. 
14 Além de aprender novos conhecimentos, as novas gerações necessitam aprender a expor seu pensamento, debater com os colegas, confrontar pontos de vista divergentes, expressar-se em público e aprimorar as argumentações; o livro é elemento fundamental para o bom aprendizado. O professor desempenha importante papel de avaliação e monitoramento das aprendizagens; o bom professor é capaz de discorrer sobre os conteúdos que leciona e os bons alunos devem saber escutar o que ele diz. Os alunos também estão na escola para serem disciplinados e aprender a enfrentar testes e provas; é desejável que os alunos percebam conexões entre as diferentes disciplinas, compondo um quadro complexo do conhecimento, não restrito apenas ao conteúdo de cada disciplina.

Por fim, ainda no tópico conhecimento, a escola promove o acesso a um saber diferenciado daquele que se aprende no âmbito da família e este é um horizonte sensível para temas como questões de gênero e sexualidade, origem da espécie humana, filosofia da história, estudo da presença africana na cultura brasileira contemporânea, arqueologia, dentre muitos outros tópicos em que se alojam questões polêmicas. Dessa forma, vale lembrar que a educação é um bem público e a escola uma instituição que deve se pautar pelos princípios da laicidade do Estado, em particular enfatizando as liberdades laicas, a saber: o acesso ao conhecimento marcado pela mais ampla liberdade de crença, pela mais ampla liberdade de consciência e pela mais ampla liberdade de manifestação e exposição e debate dos pontos de vista, em clima de respeito e negociação das diferenças. O percurso escolar é caminho de entrada no espaço público, que funciona sob lógicas completamente diferentes do que o ambiente privado das famílias e isso é fundamental de ser lembrado quando dos processos de aquisição do conhecimento. Escola não é local para confundir educação com catequese ou doutrinamento, pois isso não é próprio da alfabetização científica, em que o convívio com a dúvida, a incerteza e os questionamentos constitui a regra.

A escola não se caracteriza, contudo, apenas pela marca do acesso ao conhecimento. Cada vez mais, no cenário contemporâneo, ela é local para os processos de sociabilidade e socialização. Entendemos aqui sociabilidade 
como o aprendizado de modo livre e espontâneo que acontece entre as crianças e jovens, testando os modos de relacionamento uns com os outros, ampliando seus círculos de relação, aprendendo o valor da amizade, que não se confunde com os laços de sangue da família, pois é livremente escolhida. Ao lado disso, a escola se pauta pelo aprendizado dos processos de socialização, ou seja, o conhecimento e experimentação de um conjunto de regras que marcam nosso convívio no espaço público e que são fortemente influenciadas pelas estratégias de negociação das diferenças. $\mathrm{O}$ espaço público é local de diversidade e convívio dos diferentes, portanto local regrado por códigos que nos fazem aprender que a vida em sociedade não é mera extensão das lógicas da vida familiar. Dessa forma, é na escola, em atividades simples, que alunos e alunas aprendem códigos de respeito às diferenças, que são as mais variadas: diferenças de pertencimento religioso; diversidade de modos de expressão de gênero e orientação sexual; diversidade dos modos de organização familiar das quais alunos e alunas provém; diversidade de classe social de origem dos alunos; diversidade de compreensões políticas acerca do mundo e de vinculações a instituições como partidos, associações e sindicatos; diversidade de códigos morais de conduta; diversidade de projetos de vida; diversidade de gostos musicais e estéticos em geral; diversidade de compreensão das questões de raça e etnia; etc. Toda essa diversidade necessita de códigos de convivência e isso marca então os processos de socialização, em que crianças e jovens aprendem a conviver e negociar pontos de vista para a vida em sociedade.

Com os fortes processos de inclusão de todos e todas na escola a partir do ordenamento jurídico posto pela Constituição de 1988, esta marca da vida escolar vem adquirindo grande importância. A escola pública brasileira foi historicamente reservada para as classes médias e parte da classe operária, basicamente de crença católica e cor branca, e com certa homogeneidade de gostos culturais. Hoje, basta circular pelos corredores, salas de aula e horários de recreios das escolas para perceber a enorme diversidade de culturas juvenis. Essa situação provoca complexos processos de negociação das diferenças, que tensionam a instituição. A escola conviveu historicamente com a simples expulsão dos diferentes e aqueles que ela em geral considerava 
16 inadequados para a aprendizagem, mas no cenário contemporâneo, com a escolaridade obrigatória, esse recurso não tem mais como ser utilizado. A noção do direito à aprendizagem educação é uma conquista importante do regime democrático brasileiro, que trouxe para a escola a necessidade de produção de estratégias de negociação das diferenças visando à garantia do acesso e da permanência nos bancos escolares.

Fruto dessa situação, cada vez mais as escolas organizam seus projetos político-pedagógicos e regimentos disciplinares com vistas a promover estratégias de boa convivência entre alunos e alunas, o que envolve necessariamente mediação de conflitos. É nesse campo que a Educação em Direitos Humanos cada vez mais se faz presente. O percurso escolar não é apenas um aprofundamento no conhecimento científico do mundo, ele é também a progressiva inserção dos jovens no espaço público, a compreensão de que os modos de gestão da vida que marcam a família não são suficientes para gerir o mundo. Em outras palavras, cabe à escola mostrar que a sociedade não é mera extensão da família, embora muito se afirme que “a família é a base da sociedade”. A família é o mundo do privado e seus códigos de funcionamento são insuficientes para pensar um ordenamento com justiça social. A escola é, em geral, a primeira instituição de natureza pública em que crianças e jovens se inserem de modo prolongado e ela é, dessa forma, como um laboratório para a inserção no mundo público. Essa dimensão da função escolar, que por vezes já foi chamada de construção da cidadania, vem ganhando cada vez mais relevo nas últimas décadas, em especial pelo recuo das famílias e de outras agências como educadoras para a vida em sociedade e por conta da ampliação da escola de turno integral, na qual crianças e jovens passam o dia todo e não apenas estudam, mas convivem, visitam museus, organizam grupos pelo gosto musical, namoram, constroem redes de amizade, fazem as refeições em conjunto, dispõem de horas para estudo em grupo ou individual, organizam festas, feiras e mostras, etc. E é neste terreno que a Educação em Direitos Humanos presta valiosa colaboração. Trata-se de acionar pedagogias culturais que visam à autonomia dos indivíduos para decidir sobre si, seu corpo, suas trajetórias, seus pertencimentos políticos; mas tudo isso em estreita conexão com 
o domínio das leis, da justiça, do direito, dos deveres e obrigações e do respeito para com os demais.

Pensada a escola nesta dupla chave - local de alfabetização científica e local de preparação para a vida no espaço público em sociedade - podemos refletir agora sobre as marcas identitárias dos professores, que constituem a alma das escolas, uma vez que eles são seu quadro permanente. Coerente com o que analisamos para a escola, seus docentes podem ser pensados também em dupla chave. A primeira marca identitária dos professores é o domínio dos conhecimentos de uma disciplina, que é de onde provém sua autoridade intelectual. Professor é o que ensina e ensina a partir do conhecimento de uma determinada disciplina, por vezes área do conhecimento mais ampla, como ocorre nas séries iniciais. Para além de entender de uma disciplina, é bastante desejável que o professor tenha uma relação de empatia e gosto pelo conhecimento daquela disciplina e pelo saber de modo geral. Ensinar não é apenas transmitir conhecimentos, ensinar é mostrar o gosto pelo conhecimento e isso só é possível se quem ensina gosta do que faz. É perceptível quando estamos frente a professores e professoras que têm um gosto genuíno pelo que ensinam ou frente a outros que desempenham essa tarefa de modo essencialmente burocrático. Em resumo, para dar boas aulas de História, a pessoa tem que, em primeiro lugar, gostar de História, não há solução possível para isso a não ser por uma disposição individual. Para além de gostar, é necessário desenvolver uma didática própria de ensino, mas, sem o gostar, todo o trabalho que se segue fica comprometido. Ensinar algo para as novas gerações é em parte estar convencido da legitimidade e da importância daquilo que se ensina e se o(a) professor(a) não está animada por esse espírito, todo seu trabalho experimenta comprometimento. Uma vez que se goste e se esteja convencido da importância daquela disciplina para a vida futura das novas gerações, entra em cena o aspecto propriamente profissional da docência, que é a produção de estratégias pedagógicas adequadas, o que distingue alguém que simplesmente gosta de História daquele profissional que não apenas gosta, mas gosta e sabe ensinar História, que são professores e professoras. 
A segunda marca identitária de professores e professoras, em sintonia com o que se falou da escola, é atuar como um adulto de referência frente às novas gerações. Um aluno precisa reconhecer no professor não apenas alguém que tem expertise em determinada disciplina, mas alguém que representa o mundo dos adultos e com quem ele pode conversar acerca de muitos temas a partir das lógicas já expressadas das liberdades laicas: desenvolvendo a mais ampla liberdade de manifestação de opiniões. O professor, como adulto de referência, aposta no diálogo acerca dos temas de interesse das culturas juvenis e na apresentação do mundo, sem fazer disso uma pregação religiosa, pois ele não lida com dogmas, mas reconhece que as novas gerações podem mudar elementos que estruturam o mundo ao mesmo tempo em que precisam reconhecer como o mundo se ordena. Essa dimensão do exercício da docência mistura elementos de ética, cidadania, capacidade de diálogo aberto e franco com as novas gerações e disposição para compreender os traços marcantes das culturas juvenis, como gostos musicais. Não se trata de gostar de tudo que os jovens gostam, mas de ter disposição para dialogar com eles acerca dos temas que surgem como foco de interesse, e orientar esse diálogo pelos princípios que regem o espaço público; basicamente, a capacidade de respeitar e conviver com as diferenças, não querendo transformar o mundo em uma extensão dos valores privados. Um professor atua como adulto de referência quando ele ajuda os alunos a entender que o mundo se organiza a partir de uma multiplicidade de pontos de vista e que a vida em sociedade exige um considerável grau de negociação das diferenças. E mais uma vez salientamos que todo esse esforço de convívio com a diferença deve ser feito no quadro dos direitos humanos e, para isso, as escolas devem se ocupar da Educação em Direitos Humanos.

\section{O CAMPO DA EDUCAÇÃO EM DIREITOS HUMANOS}

A compreensão moderna de direitos humanos está conectada com o postulado da dignidade humana universal: há um valor intrínseco à vida humana que a torna digna. E dessa dignidade, estendida a todos os seres humanos (independentemente de gênero, raça, credo ou nacionalidade), 
decorre um conjunto mínimo de direitos indivisíveis, inalienáveis e garantidos no âmbito global, escapando às fronteiras geográficas dos Estados nacionais. São direitos fundamentais à existência humana. É nessa direção que os direitos humanos vêm sendo definidos, pelo menos desde a criação da Organização das Nações Unidas em 1948. Desde então, vemos um progressivo engajamento da comunidade internacional no sentido de estabelecer com maior clareza e profundidade quais seriam esses direitos mínimos, bem como quais são os compromissos dos Estados nacionais em garantir a efetividade deles.

Um elemento imprescindível para que os indivíduos e os povos tenham seus direitos humanos efetivados é a consciência de sua existência. Por isso a importância da Educação em Direitos Humanos: é preciso ensinar a todos os destinatários desses direitos que eles existem e podem ser acionados, e que devem cobrar de seus Estados nacionais a sua efetivação e denunciar para a comunidade internacional as situações de violação. $O$ principal esforço da ONU em promover o tema ocorreu com a declaração da Década da Educação em Direitos Humanos, de 1995 a 2004. Com isso, os Estados compositores das Nações Unidas foram instados a promoverem o tema em âmbito interno, no intuito de estimular uma cultura de respeito e promoção dos direitos humanos. Como orientação para o cumprimento da tarefa, foi elaborado o Plano de Ação Internacional da Década das Nações Unidas para a Educação em Matéria de Direitos Humanos (1995-2004)³.

Aproveitando as iniciativas e trocas de experiências promovidas ao longo da década, em dezembro de 2004 a Assembleia Geral das Nações Unidas proclamou o Programa Mundial para Educação em Direitos Humanos (Resolução no 59/113-A). O objetivo foi oferecer orientações e subsídios para a construção de programas educacionais voltados ao tema. Enquanto a década foi prevista para ocorrer durante um determinado período, o Programa Mundial é uma proposta permanente que vem sendo aplicada em fases, sendo a primeira delas (2005-2009) voltada para a educação básica ${ }^{4}$,

\footnotetext{
3 Disponível em: < http://www.gddc.pt/direitos-humanos/serie_decada_1_b.pdf > . Acesso em: out. 2015.

4 Disponível em: <http://unesdoc.unesco.org/images/0014/001478/147853por.pdf> . Acesso em: out. 2015.
} 
a segunda (2010-2014) ${ }^{5}$ para a educação superior e a atual terceira (20152019) voltada para a mídia ${ }^{6}$. Ainda no âmbito internacional, cabe citar a aprovação, em março de 2011, da Declaração das Nações Unidas Sobre a Educação e Formação em Direitos Humanos (Resolução 16/1), adotada pela Assembleia Geral da ONU em dezembro do mesmo ano (Resolução 66/137).

Voltando-se ao plano interno do Brasil, a preocupação com os direitos humanos toma corpo a partir dos anos 1980, invocada pelos movimentos sociais na luta a favor do encerramento da ditadura militar e reinstauração do regime democrático republicano. Como afirma Sader (2007, p. 81), “[...] no período prévio à ditadura militar, o tema dos direitos humanos não fazia parte da pauta de debates políticos, nem dos programas educacionais, ficando reduzido aos currículos dos estudos jurídicos. Foi durante a ditadura militar que o tema dos direitos humanos ganhou espaço de destaque". No plano nacional, comissões de direitos humanos, compostas por juristas, membros da Igreja Católica, do meio universitário, de movimentos sociais, foram incorporados ao campo das lutas políticas, dos debates, das denúncias, das matérias de jornal, de teses acadêmicas. A temática passou a disputar espaço no discurso hegemônico, no plano nacional.

A Constituição Federal de 1988 consolida essa demanda, incluindo em seu texto diversos dispositivos relacionados à garantia de direitos fundamentais à dignidade humana. Especial destaque merecem os diversos incisos do Artigo $5^{\circ}$, que concentram a maior parte desses direitos. Com isso, os direitos humanos tornam-se o debate mais presente na agenda pública nas décadas de 1980 e 1990. O compromisso com o tema é reafirmado pelo Estado brasileiro em 1996, com a elaboração da primeira edição do Programa Nacional de Direitos Humanos I (PNDH). Uma segunda edição do programa foi elaborada em 2002, até chegarmos à terceira e mais recente versão, o PNDH III, em 2010. Nessa versão do Plano Nacional de Direitos Humanos há um eixo orientador dedicado com exclusividade à promoção e garantia da Educação em Direitos Humanos.

\footnotetext{
5 Disponível em: <http://unesdoc.unesco.org/images/0021/002173/217350por.pdf> . Acesso em: out. 2015.

6 Disponível em: <http://unesdoc.unesco.org/images/0023/002329/232922POR.pdf> . Acesso em: out. 2015.
} 
Com a Portaria no 98, em julho de 2003, ocorre a criação do Comitê Nacional para a Educação em Direitos Humanos, vinculado ao Ministério da Justiça. Esse grupo, em conjunto com a Secretaria de Direitos Humanos da Presidência da República e o Ministério da Educação, encarrega-se da elaboração do Plano Nacional de Educação em Direitos Humanos (PNEDH), Portaria $n^{0}$ 66/2003 da $\mathrm{SEDH}^{7}$. Esse plano foi revisto e sua versão final data de dezembro de $2006^{8}$. O PNEDH dialoga com o Programa Mundial de Educação em Direitos Humanos da ONU, contendo princípios e ações programáticas orientadoras da ação política do Estado voltadas para cinco eixos: educação básica, educação superior, educação não formal, educação dos profissionais dos sistemas de justiça e segurança e educação e mídia. Em abril de 2009, o Fundo Nacional de Desenvolvimento da Educação (FNDE) elabora a Resolução CD/FNDE $n^{\circ} 15$, que estabelece orientações e diretrizes para a produção de materiais didáticos e paradidáticos voltados para a promoção, no contexto escolar, da Educação em Direitos Humanos ${ }^{9}$. Em 2012, o Conselho Nacional de Educação, por meio do Parecer n 8/2012 e da Resolução n 1/2012, aprova as Diretrizes Nacionais para a Educação em Direitos Humanos (DNEDH) ${ }^{10}$. Não se trata de diretrizes curriculares, pois não tratam apenas de currículo, englobando também gestão da vida institucional educativa.

A aprovação da segunda versão do Plano Nacional de Educação em 2014 (Lei 13.005/2014) conferiu aos municípios o prazo de um ano para se adequarem, elaborando os seus respectivos Planos Municipais de Educação (PMEs), sob pena de restrição de repasses financeiros e da adesão a programas do governo federal voltados para a educação. $O$ não recebimento de tais recursos traria consequências negativas para as contas dos municípios, motivo pelo qual houve certa pressa na aprovação e sanção dos planos pelas autoridades municipais até 24 de junho de 2015. A pressa

\footnotetext{
7 Disponível em: < http://new.netica.org.br/prevencao/cartilha/plano-educdh.pdf> Acesso em: out. 2015.

8 Disponível em: <http://portal.mec.gov.br/index.php?option $=$ com_docman\&view $=$ download\&alias $=2191-$ plano -nacional-pdf\&category_slug=dezembro-2009-pdf\&Itemid=30192> . Acesso em: out. 2015.

9 Disponível em: <https:/www.fnde.gov.br/fndelegis/action/UrlPublicasAction.php?acao=abrirAtoPublico\&sgl_tipo= RES\&num_ato $=00000015 \& s e q \_$ato $=000 \& v l r \_$ano $=2009 \& s g l \_o r g a o=C D / F N D E / M E C>$. Acesso em: out. 2015. 10 Disponívelem: <http://portal.mec.govbr/index.php?option $=$ com_docman\&view $=$ download\&alias $=10889$-rcp001 -12\&category_slug=maio-2012-pdf\&Itemid=30192 >. Acesso em: out. 2015.
} 
22 dificultou a amplitude e profundidade dos debates locais com a sociedade civil e resultou em diversas cidades do país enfrentando forte lobby religioso das igrejas militando contra a inclusão do que foi chamado de "ideologia de gênero" nas escolas. As assembleias legislativas municipais se viram constrangidas a remover quaisquer referências ao enfrentamento do machismo e da homofobia, lesbofobia e transfobia nas escolas, bem como remover políticas voltadas à inclusão das minorias sexuais e compreensão sobre questões de gênero e sexualidade. De toda forma, esses temas estão postos para debate nas escolas através de um número de ações e programas, bem como de materiais didáticos e livros que já circulam nacionalmente. A necessidade de debater tais temas, bem como a compreensão da Educação em Direitos Humanos, leva à necessidade de formação docente continuada.

\section{FORMAÇÃO DOCENTE CONTINUADA EM EDUCAÇÃO EM DIREITOS HUMANOS}

A formação continuada dos professores da educação básica encontrase entre as prioridades do Ministério da Educação explicitadas no Plano de Desenvolvimento da Educação (PDE), para garantir uma educação de qualidade, centrada no aprendizado do educando. A criação da Política Nacional de Formação de Profissionais do Magistério da Educação Básica é uma das respostas a esse compromisso. Instituída pelo Decreto 6.755 de 29 de janeiro de 2009, a Política Nacional de Formação de Profissionais do Magistério da Educação Básica tem por finalidade apoiar, em regime de colaboração entre a União, os Estados, o Distrito Federal e os Municípios, a formação inicial e continuada dos professores das redes públicas da educação básica. Em consonância com o Plano de Desenvolvimento da Educação, que prioriza e fomenta a formação docente continuada, bem como pelo reconhecimento da complexidade do espaço da sala de aula no contexto contemporâneo, pelas razões anteriormente expostas, foi desenvolvido o curso de extensão "Educação em Direitos Humanos", no âmbito do Programa de FORPORF/UFRGS (Centro de Formação de Professores) da Universidade Federal do Rio Grande do Sul. 
O curso foi realizado no período de dezembro de 2014 a agosto de 2015, na modalidade semipresencial - com carga horária de 36 horas presenciais e 144 horas à distância - em quatro polos abrangidos pela Secretaria de Educação à Distância da UFRGS: Porto Alegre, Santo Antônio da Patrulha, São Francisco de Paula e Sapucaia do Sul. O principal objetivo do curso foi oferecer a professores(as) do Ensino Fundamental e a agentes jurídico-estatais conhecimentos sobre a construção histórica de afirmação e garantia de direitos humanos, estimulando reflexões sobre como trabalhar e fomentar o tema dos direitos humanos na sala de aula, bem como o desenvolvimento de práticas de convivência harmônica no espaço público por meio da mediação de conflitos no território escolar, efetivando assim uma formação para a cidadania. A equipe do curso era composta por professores, com mestrado ou doutorado em diversas áreas (Educação, Antropologia, Sociologia, Direito), bem como por tutores presenciais e à distância que acompanhavam as atividades realizadas, auxiliando os alunos nas suas dúvidas e no desenvolvimento dos trabalhos. Realizaram o curso sessenta e quatro professores que atuam no ensino fundamental da rede pública do estado do Rio Grande do Sul.

O curso foi organizado a partir de cinco módulos. No primeiro módulo, foi realizada uma introdução sobre o ambiente virtual Moodle tendo como objetivo capacitar os cursistas a utilizar a plataforma ao longo do curso, minimizando as dificuldades de manejo no ambiente virtual e possibilitando um bom aproveitamento e acompanhamento do curso. O segundo módulo, "Introdução aos Estudos de Direitos Humanos”, abordou a relevância teórica e política dos direitos humanos, em especial para o campo da educação, dando ênfase às legislações atuais que orientam as discussões de temas relacionados aos direitos humanos e seus reflexos nas práticas docentes e discentes, de modo a oferecer aos educadores instrumentos de formação para a cidadania, por meio do conhecimento dos direitos fundamentais e respeito à pluralidade humana. No terceiro módulo, propôs-se uma discussão acerca dos marcadores sociais da diferença que perpassam o espaço da sala de aula, como gênero, sexo, orientação sexual, classe social, raça/etnia, geração, entre outros. O reconhecimento das diversidades presentes em 
24 sala de aula possibilita a compreensão das diferentes sensibilidades jurídicas em direitos humanos e suas expressões no contexto escolar e curricular. Dessa forma, o objetivo desse módulo foi proporcionar discussões e análises de temas, tais como: sexismo, machismo, homofobia, racismo, e demais formas de intolerância, à luz dos estudos culturais e dos estudos de gênero no ambiente escolar.

No quarto módulo, intitulado "Mediação de conflitos no espaço escolar”, propôs-se uma reflexão sobre a complexidade do espaço escolar contemporâneo no qual numerosos conflitos sociais se manifestam. Partindo do reconhecimento da diversidade que perpassa a sala de aula, através de uma multiplicidade de códigos, trajetórias, identidades e assumindo que o conflito é inerente às relações sociais, o módulo procurou apresentar e discutir as diferentes possibilidades e estratégias de mediação de conflitos escolares a serem operacionalizadas nas atividades pedagógicas. Buscou-se também analisar os papéis dos diferentes agentes da comunidade escolar (alunos e alunas, responsáveis, professores e professoras, gestores, demais profissionais) na produção e resolução dos conflitos no espaço escolar, a partir do marco teórico e político de um projeto pedagógico escolar de afirmação e garantia de direitos humanos. O último módulo do curso foi o Seminário Integrador, cuja proposta era que os cursistas diagnosticassem uma situação violadora de direitos humanos nas escolas onde trabalham e elaborassem, para seu enfrentamento, uma dinâmica de intervenção em sala de aula. Nesse sentido, a atividade possibilitou que os educadores exercitassem, na prática, as reflexões e discussões desenvolvidas no decorrer do curso, tanto pela capacidade de observar e identificar as situações que configurassem uma violação de direitos humanos quanto pela iniciativa de elaborar uma atividade com os seus alunos que pudesse abordar o tema e mediar a situação em sala de aula.

A conclusão do Seminário Integrador ocorreu durante o encontro presencial de encerramento do curso, realizado no auditório da Faculdade de Educação da UFRGS, que possibilitou o contato pessoal entre seus diversos participantes (cursistas de todos os polos e a equipe pedagógica do curso). Nesse encontro, realizado ao longo de um dia, os sessenta e quatro alunos que 
concluíram o curso assistiram a uma conferência intitulada Direitos humanos e diversidade na escola e também apresentaram seus trabalhos finais elaborados para o módulo do Seminário Integrador. Os trabalhos finais dos alunos do curso versaram sobre diversos temas ligados aos direitos humanos, como raça/etnia, classes sociais, deficiência e acessibilidade na escola, gênero e sexualidades, geração e pertencimentos religiosos. Considerando-se que os temas partiram dos próprios alunos do curso e da produção de diagnósticos a partir da sala de aula, percebe-se como os temas dos direitos humanos fazem parte do cotidiano escolar e constituem, de forma muito intensa, as tramas das relações que se estabelecem tanto na sala de aula como na comunidade escolar de forma mais ampla. Os temas de direitos humanos não podem ser introduzidos na sala de aula, eles já estão nela, nas microrrelações cotidianas que atravessam sujeitos de múltiplos e diversos pertencimentos e, por essa razão, precisam ser trabalhados pedagogicamente em sala de aula, de modo que a própria escola não seja um espaço de reprodução de violações de direitos e invisibilidades. Os trabalhos dos alunos do curso também possibilitaram evidenciar o engajamento em sala de aula, a imensa capacidade criativa que mobiliza os professores do ensino fundamental a partir de diversas metodologias: da utilização de pesquisa em sala de aula, observações, aplicação de questionários, etc., e utilizando-se de múltiplos recursos como poesias, vídeos, músicas, legislações, relatos, experiências, brincadeiras, brinquedos. Os alunos do curso compartilharam as múltiplas possibilidades de trabalhar com direitos humanos em sala de aula.

Dessa forma, o encerramento do curso proporcionou um momento extremamente rico de trocas de experiências, de relatos e reflexões a partir de diversos contextos de sala de aula e das estratégias criadas pelos alunos do curso para, nas suas vivências de sala de aula, abordar com seus alunos do ensino fundamental os diversos temas de direitos humanos. O curso possibilitou observar também como os direitos humanos são significados nas práticas cotidianas dos sujeitos envolvidos nesse processo, o que permite ampliar esses sentidos para além do que estabelecem normativas e tratados internacionais de direitos humanos, dando contornos a partir das percepções 
26 vividas nos processos sociais por esses atores e contribuindo, assim, para a construção de uma educação com cidadania.

Em sintonia com esta trajetória, o conjunto de artigos que seguem aprofundam questões colocadas no curso, ao modo de um material para continuidade dos estudos. Nosso propósito é não apenas enfocar com mais cuidado alguns tópicos levantados ao longo do curso, como também abrir possibilidades de pensar a Educação em Direitos Humanos em outros temas, todos eles questões sensíveis em sala de aula. A meta de todas as ações é transformar a escola em um território de respeito à diversidade, de negociação entre muitos marcadores da diferença e convívio fraterno entre alunos e alunas. Todas as ações estão em sintonia com a noção de escola como espaço público, lugar de negociação dos pontos de vista particulares e de respeito pelas diferenças, possibilitando a todos boas oportunidades de aprendizado, sem exclusões ou discriminações. Não é tarefa fácil, e revela o empenho de tantos docentes em ir além das aulas de suas disciplinas, e fazer do percurso escolar uma formação para cidadania e justiça social. São temas sensíveis, abordados na sala de aula com sensibilidade e em sintonia com os direitos humanos.

\section{REFERÊNCIAS}

SADER, Emir. Contexto histórico e Educação em Direitos Humanos no Brasil: da ditadura à atualidade. In: SILVEIRA, Rosa Maria Godoy Silveira et al. Educação em direitos humanos: fundamentos teórico-metodológicos. João Pessoa: Editora Universitária, 2007. Disponível em: < http://www.dhnet.org.br/dados/livros/edh/br/fundamentos/06_cap_1_artigo_03.pdf>. Acesso em: set. 2015. 


\section{DIREITOS HUMANOS: TUDO A VER COM A NOSSA VIDA ${ }^{1}$}

\section{Paulo César Carbonari}

Tem assunto de todo tipo. Uns são importantes, outros nem tanto! Uns têm tudo a ver, outros nem tanto! Conversar sobre um assunto que tem tudo a ver com a vida, com a sua vida, com a vida de cada uma e de todas as pessoas, os direitos humanos, é ocupar-se daquilo que realmente vale a pena.

Como assim, se muitas pessoas falam que quem defende direitos humanos prefere os bandidos às pessoas "de bem"? Como assim, se quando se fala em direitos em geral se esquece dos deveres? Como assim, se já há tantos direitos proclamados e a vida continua muito difícil para a maioria das pessoas?

É exatamente para enfrentar questões como essas e várias outras que propomos esta conversa. Queremos apresentar algumas ideias para mostrar que direitos humanos têm tudo a ver com a vida, a sua vida, a vida de cada uma e de todas as pessoas, a vida daquelas pessoas que você conhece e até daquelas que você nunca viu, a vida das pessoas de quem você gosta e também daquelas de quem você não gosta.

1 Este texto foi originalmente publicado como um caderno de apoio pedagógico pela Comissão de Direitos Humanos de Passo Fundo (CDHPF), da qual o autor é associado e membro da coordenação geral. A publicação foi feita em 2012 no âmbito do Projeto Educação Popular em Direitos Humanos, com apoio da Secretaria dos Direitos Humanos da Presidência da República (Convênio nº 750325/2010 SDH/PR). O texto foi revisado e completado para esta edição. 
O motivo é simples: a vida não vale porque tem algum equivalente, ou porque pode ser trocada por qualquer coisa. A vida não tem preço, simplesmente vale! A vida humana, então, vale simplesmente porque as pessoas são seres com dignidade.

\section{OLHANDO A VIDA}

Para a maioria dos brasileiros e das brasileiras a vida é ainda muito difícil. Por quê? A pobreza e a violência estão presentes no cotidiano. Somase a elas a desigualdade, que põe milhões em situação de inferioridade, sem reconhecimento, em situações de discriminação, distantes do acesso aos bens públicos e também da possibilidade de ter acesso a eles. Em outras palavras, esse complexo de situações faz com que milhões de pessoas ainda não tenham os direitos humanos como conteúdo cotidiano e concreto em suas vidas. Pior, são facilmente transformadas em vítimas reais e/ou potenciais de violações.

Mas há esperanças! Passos vêm sendo dados no sentido de melhorar a vida das pessoas. Há garantias legais e programas de inclusão. Todavia, isso ainda é insuficiente para fazer frente às históricas escolhas que marcam a sociedade brasileira. Sim! São escolhas sociais, políticas, econômicas e culturais que fazem a vida ser melhor ou pior. No Brasil, as classes dirigentes historicamente escolheram mais a seu favor do que para efetivamente garantir condições de vida melhor às classes populares e ao conjunto da população. Escolheram pela desigualdade, pela violência e pelo conservadorismo. As transições políticas, econômicas e sociais são permanentes e duram décadas. Todavia, dificilmente se traduzem em efetiva inclusão em escala capaz de transformar profundamente as relações e promover o reconhecimento efetivo dos direitos humanos. Os abismos que separam as pessoas, mesmo com todo o esforço para superá-los, continuam imensos e, em alguns casos, se ampliam.

Reagindo a tudo isso, as pessoas que sentem na carne a opressão, a exploração, a expropriação, a escravidão, a pobreza, a desigualdade e a violência não se calam. Organizam-se e fazem lutas. É dessa maneira, 
organizando a resistência, que o povo organizado construiu condições melhores de vida, construiu e continua construindo direitos.

$\mathrm{Na}$ história recente do Brasil, foi através da luta popular que foi sendo construído o processo de democratização e de superação da ditadura militar; foi indo às ruas para colher assinaturas que foram garantidas emendas populares incorporadas à Constituição Federal de 1988; foi organizando o novo sindicalismo que conquistas de direitos foram reconhecidas e consagradas; foi reunindo mulheres e indo às ruas que o movimento feminista e de mulheres fez avançar a luta por seus direitos; foi ocupando e resistindo que os sem-terra ajudaram a realizar o pouco de reforma agrária que já foi feita; foi denunciando e exigindo respeito que negras e negros lutaram e ainda lutam contra o racismo e os resquícios de quase 400 anos de escravidão; foi com a educação popular, realizada nos recantos do país, que ONGs e movimentos sociais constituíram lideranças populares; foi nas comunidades de base que uma nova igreja brotou; foi nas ocupações de prédios abandonados e terrenos de especulação que a luta pela moradia ganhou status de direito humano; foi com organização que crianças e adolescentes passaram a ser reconhecidos como sujeitos de direitos; foi nas ruas e de cara pintada que a juventude movimentou o país, levando à destituição de um presidente; enfim, foi e continua sendo assim que os pobres do campo e da cidade constroem lutas por direitos. A vida mostra que os direitos humanos são um conteúdo concreto e que colabora para torná-la ainda melhor para todas as pessoas.

\section{SENTIDO DOS DIREITOS HUMANOS}

Mas afinal, de que falamos quando tratamos de direitos humanos? Falar de direitos humanos é tratar de um tema complexo, controverso e que tem vários sentidos. Isso porque são muito diversos os agentes e as posições assumidas pelas pessoas. Assumir um posicionamento sobre os direitos humanos não significa se opor a outras posições. Antes pelo contrário; isso 
30. é feito na expectativa de que haja incentivo a outros posicionamentos e ao debate.

A complexidade dos direitos humanos ocorre porque o tema se abre a abordagens de vários campos do conhecimento: filosofia, sociologia, psicologia, direito, teologia, entre outras; em consequência, exigindo preferencialmente posturas interdisciplinares e até transdisciplinares. O fato de direitos humanos ter vários sentidos deve-se à condição histórica e às várias concepções da dignidade humana, que é o objeto dos direitos humanos. A controvérsia, a polêmica, deve-se à presença de agentes diversos na arena de debates sobre o sentido dos direitos humanos e também do que significa atuação efetiva, o que exige abertura à diversidade e à pluralidade sem que isso leve a evitar posicionamentos.

Tomando em conta a experiência de atuação em direitos humanos e no contexto de uma compreensão histórico-crítica, os direitos humanos radicam na construção de reconhecimento, na relação, entre as pessoas antes de serem faculdade ou titularidade de indivíduos. São prerrogativas disponíveis a cada um dos indivíduos. E, além disso, os direitos humanos se constituem em construção feita na relação com os outros e que se traduz em processos de criação de condições de interação e reconhecimento em várias dimensões: interpessoal (singular), grupal-comunitária (particular), genérico-planetária (universal). Nesse processo se conjugam o cotidiano e a utopia, a cultura e a natureza, a ação e a reflexão. Em outras palavras, os direitos humanos nascem na e da relação de alteridade, das relações e das interações alternativas.

Os direitos humanos referenciam-se na dignidade humana como condição e possibilidade da produção e reprodução de sua vida material, da corporeidade, da identidade cultural e social, da participação política e da expressão livre; enfim, do ser sujeito de direitos. Isso porque a realização dos direitos humanos é um processo histórico, assim como é histórico seu conteúdo, a dignidade humana. Nesse sentido, o conteúdo dos direitos humanos está mais na materialidade das condições e possibilidades de humanização e menos no enunciado dos instrumentos e mecanismos que os explicitam como pactos de convivência e/ou regulação. Isso não significa desconhecer a força 
dos pactos; antes, indica que têm um lugar que não esgota o conteúdo dos direitos humanos.

A ética nos informa que os direitos humanos se constituem em exigências que estão referenciadas na dignidade humana dos sujeitos de direitos. Isso torna os direitos humanos não disponíveis a transações em qualquer das circunstâncias, ao mesmo tempo em que exigem condições da efetivação histórica. Ou seja, os direitos humanos têm uma dimensão de utopia que escapa à realização histórica, por um lado, mas que exige sua efetivação no cotidiano histórico, por outro.

A perspectiva histórica remete à realização e às escolhas, o que inaugura a dimensão política dos direitos humanos. A realização dos direitos humanos cobra da ação política que esteja centrada na presença de todos os agentes como sujeitos (autores, portanto, nunca somente atores) diversos, múltiplos, plurais, tanto na deliberação como na implementação. Subjetividades e instituições não substituem umas às outras; antes, têm perspectivas e responsabilidades distintas e complementares, sempre, porém, orientadas pelo conteúdo dos direitos, o parâmetro da ação. Escolhas pautadas por direitos humanos põem a primazia na pessoa (sem separá-la das condições culturais e naturais necessárias à sua reprodução), em detrimento das coisas, do patrimônio - o que significa afastar-se de dinâmicas econômicas, políticas, culturais e sociais que modelam as vontades para que entendam a escolha pelas coisas como uma escolha pelos direitos humanos. Em complemento, escolhas por direitos humanos demandam a promoção de todas e de cada pessoa, por um lado, e a proteção daquelas em situação de maior vulnerabilidade, além do reconhecimento de violações que geram vítimas, que cobram reparação, por outro.

Em suma, em traços rápidos e resumidos, desenhamos um sentido para os direitos humanos que tem na realização efetiva da dignidade de cada uma e de todas as pessoas o seu conteúdo fundamental, ao mesmo tempo em que se convertem em exigência para que nenhuma pessoa tenha seus direitos violados ou ainda não realizados. É isso que significa dizer que direitos humanos se constituem em construção crítica de e em condições históricas. 
E como nascem e se desenvolvem os direitos humanos? Eles nascem e se afirmam no processo histórico. É nas lutas populares que nascem os direitos humanos. É porque os que não têm direitos exigem reconhecimento, maior liberdade e distribuição equitativa dos bens públicos que os direitos humanos fazem lutas, "põem a boca no mundo", para que os direitos passem a ser garantidos. É porque as vítimas de violações dos direitos humanos reclamam reparação que os direitos precisam ser efetivados. É porque continuam na luta, mesmo contra todo tipo de "dono" e todo tipo de "cerca", enfrentando todo tipo de adversidade e repressão, que a sociedade toda passa a ter direitos. Por isso que os direitos humanos são uma construção histórica que nasce das lutas populares. Por isso que são afirmados historicamente na luta permanente dos povos, das pessoas, das vítimas, contra a exploração, o domínio, a vitimização, a exclusão e todas as formas que reduzem o ser humano.

Direitos humanos não nascem das declarações, dos tratados, dos pactos, em suma, das leis, sejam elas nacionais ou internacionais.

A positivação dos direitos gera condições, instrumentos e mecanismos para que possam ser exigidos publicamente, o que é muito importante, mas também tende a enfraquecer sua força constitutiva e instituinte, como processo permanente de geração de novos conteúdos, de novos direitos e de alargamento permanente do seu sentido. Ao serem institucionalizados em documentos jurídicos, os direitos humanos passam a ser exigência para todos. Ou seja, toda pessoa, toda organização social e, de modo particular, o poder público, estão comprometidos com o respeito e a promoção dos direitos de todas as pessoas.

Esse é um passo muito importante e significa que exigir que os direitos se tornem leis e que elas sejam cumpridas é fundamental para a efetivação dos direitos humanos. Mas, além disso, é preciso manter acesa a luta popular pelos direitos humanos, até porque é ela que está na raiz das leis e das lutas pela sua efetivação. Lutar por direitos humanos é lutar para que a lei esteja 
na vida concreta e também para que a vida concreta seja a fonte crítica de toda a lei.

\section{CARACTERÍSTICAS DOS DIREITOS HUMANOS}

Quais são as qualidades dos direitos humanos de modo específico? Eles não seriam parte do conjunto dos direitos em geral? A concepção ampla e aberta de direitos humanos que desenhamos entende que os direitos humanos têm as seguintes características centrais: “Todos os direitos humanos são universais, indivisíveis e interdependentes e estão relacionados entre si. A comunidade internacional deve tratar os direitos humanos de forma global e de maneira justa e equitativa, em pé de igualdade, dando a todos o mesmo peso" (ONU, Declaração e Programa de Ação de Viena, 1993, $\S 5^{\circ}$ ).

\subsection{Universalidade}

A universalidade dos direitos humanos radica na dignidade humana construída por processos históricos. Os seres humanos não nascem livres e iguais em dignidade e direitos, como diz a Declaração Universal dos Direitos Humanos (1948). Os seres humanos se tornam livres e iguais em dignidade e direitos porque estabelecem processos e dinâmicas que valorizam a liberdade, a igualdade e a dignidade. Por isso, é na vivência concreta que se pode (ou não) reconhecer em cada uma e em todas as pessoas, na diferença e na diversidade que lhe são constitutivas, um sujeito de direitos. A universalidade dos direitos humanos exige sempre reconhecimento da diversidade e da pluralidade, que são intrínsecas à dignidade humana. Dessa forma, a universalidade dos direitos humanos é uma construção que parte do reconhecimento da dignidade de cada pessoa, de sua singularidade, que é única, do reconhecimento de que as pessoas se fazem de diferentes formas e têm aspirações comuns e também diferentes. Dizer que direitos humanos 
são universais é querer que cada pessoa possa viver em condições concretas nas quais seja reconhecida como pessoa, simplesmente como pessoa.

\subsection{Indivisibilidade}

A indivisibilidade dos direitos aponta para a necessidade de superação das leituras geracionais dos direitos humanos, no sentido de que há direitos que vieram primeiro e por isso são mais importantes. Todos os direitos humanos, os civis e políticos; os econômicos, sociais e culturais; os de solidariedade, entre outros, constituem, juntos, um todo indivisível, o conjunto dos direitos humanos. A necessidade do compromisso e de responsabilidade pela garantia efetiva vale para todos os direitos, igualmente. Dessa forma, o conjunto dos direitos humanos constitui um todo que exige a construção de dinâmicas e processos concretos e adequados à efetivação de cada direito como direito humano e de todos os direitos humanos como realização da dignidade da pessoa humana.

\subsection{Interdependência}

A interdependência dos direitos complementa as duas noções anteriores para dizer que a realização de um direito exige a realização dos demais. Por exemplo, não há como realizar direitos civis e políticos sem que os direitos econômicos, sociais e culturais também sejam realizados. É claro que há procedimentos e instrumentos distintos para efetivar diferentes direitos. No entanto, é central que todos sejam realizados, mesmo que nem sempre de uma única vez, mas ao menos de tal forma a não admitir retrocessos. Nesse sentido, os direitos humanos se constituem em base que não pode ser ultrapassada nas relações interpessoais, na efetivação de políticas públicas, nas decisões judiciais, nas práticas culturais e educativas; enfim, os direitos humanos orientam o tipo de desenvolvimento e de democracia que se efetiva numa determinada sociedade, da mesma forma que os tipos de 
desenvolvimento e de democracia que se vive numa sociedade podem ser mais ou menos favoráveis aos direitos humanos.

As características dos direitos humanos esboçadas trabalham com a noção de ser humano como construção histórica, procuram superar a ideia de ser humano genérico e abstrato e abrem-se para compreendêlo na sua concretude. O desdobramento imediato é a necessidade de construção de dinâmicas e processos que tornem os direitos humanos uma realidade concreta. Por isso, acrescentamos as características que seguem: a irrenunciabilidade, a imprescritibilidade, a exigibilidade e a justiciabilidade.

\subsection{Irrenunciabilidade}

A irrenunciabilidade dos direitos humanos baseia-se na compreensão de que os direitos humanos não são concedidos à pessoa humana por um terceiro (o Estado, por exemplo) e também não são eleitos ou escolhidos por ela. A construção histórica de seu reconhecimento faz com que não seja possível abrir mão deles e nem deles possam ser retirados os direitos de forma unilateral. Ou seja, uma pessoa não pode renunciar a seus direitos; se pudesse fazer isso, seria como se estivesse abrindo mão de parte ou de toda a sua humanidade singular. Por outro lado, se a pessoa não pode renunciar a direitos humanos, também nenhum outro agente, de modo particular o Estado, tem qualquer justificativa legítima para subtraí-los. Isso faz com que os direitos humanos não estejam disponíveis ao Estado para que possa escolher realizá-los ou não. Considera-se, no entanto, que a existência jurídica dos direitos humanos implica sua presença no ordenamento jurídico de cada país, em sua constituição e na ratificação dos tratados internacionais. Isso faz com que muitos Estados não atuem no sentido de proteção da pessoa e por isso não incorporem juridicamente os direitos humanos. Esse fato somente demonstra que o Estado que age desta forma é omisso. O problema que se instala numa situação dessas trata da possibilidade de a pessoa invocar o direito internacional dos direitos humanos para sua proteção. Para alguns, se os direitos não estiverem reconhecidos na legislação do país, qualquer 
medida internacional seria uma intervenção externa, ferindo a soberania. Para outros, a soberania tem limites exatamente no que diz respeito aos direitos humanos. O risco, porém, é que há a possibilidade de uso dos direitos humanos como argumento geopolítico para intervenções ilegais e até guerras (há muitos exemplos disso na história recente), o que obviamente não é legitimado pelos direitos humanos. Em suma, mesmo considerando esses problemas, entender os direitos humanos como irrenunciáveis dá força e poder à pessoa e exige pôr as instituições a seu serviço.

\subsection{Imprescritibilidade}

A imprescritibilidade dos direitos humanos baseia-se na compreensão de que os direitos não cessam no tempo. Ou seja, os direitos humanos são valores ao mesmo tempo construídos historicamente e que transcendem às circunstâncias epocais e podem ser exigidos a qualquer tempo. Isso vale também para situações de violação: a vítima pode exigir reparação e justiciabilidade a qualquer momento. É por este motivo que os "crimes contra a humanidade" podem ser julgados a qualquer tempo. Essa característica dos direitos humanos ajuda a proteger as pessoas contra o arbítrio dos violadores, visto que, cessadas as circunstâncias de maior cerceamento dos direitos, as pessoas, sobretudo as vítimas, que estavam impedidas de promover ações para proteger seus direitos, podem exigir reparação. É também fundamental compreender que a imprescritibilidade compromete o Estado com a promoção e a proteção dos direitos humanos independente do governo. Ou seja, um governo que sucede a outro não pode alegar impossibilidade de responder às garantias dos direitos em caso de governos anteriores não terem agido dessa forma. A responsabilidade pela garantia dos direitos é do Estado e, portanto, todo governo está submetido a agir pela sua garantia. Assim que se, por exemplo, uma pessoa foi torturada durante o regime militar e o Estado for condenado a indenizá-la em período democrático, ele terá que pagar a indenização, não podendo alegar que o fato teria acontecido em outro período, em outro governo, e que não teria responsabilidade com isso. 
A exigibilidade reconhece que cada cidadão tem a possibilidade de demandar a realização dos direitos, cabendo ao Estado, sobretudo, e à sociedade civil, em complemento, a busca de condições para sua efetivação. Um dos instrumentos mais significativos que permitem a realização de condições para a exigibilidade dos direitos humanos é a efetivação de políticas públicas de direitos humanos e o posicionamento dos direitos humanos como parâmetro de todas as políticas públicas. A exigibilidade é uma das características mais significativas da historicidade dos direitos humanos, visto que dá à cidadania condições para se organizar, inclusive de forma coletiva, para realizar mobilizações e pressões sobre governos e agentes públicos do Estado, a fim de cobrar a proteção e a promoção dos direitos humanos e a reparação das violações.

\subsection{Justiciabilidade}

A justiciabilidade dos direitos humanos exige reconhecer que os direitos humanos podem ser demandados ao Poder Judiciário sempre que não forem realizados. Há muitos passos ainda a serem dados, especialmente no sentido de dotar a sociedade de conhecimento e de instrumentos concretos para demandar dos Tribunais o justo remédio para as violações dos direitos humanos. Há todo um trabalho a ser feito neste campo, de tal forma que o poder do Estado em matéria de direitos humanos possa ser também exercido pelo Judiciário que, infelizmente e em grande medida, ainda desconhece a possibilidade de tratar de direitos desta ordem. Exigir justiça em geral e em sentido de justiciabilidade é uma das principais lutas pelos direitos humanos.

\subsection{Historicidade}

A historicidade parte da constatação de que os direitos humanos são afirmados na história e que isso faz com que a compreensão do que são os direitos, quais são os tipos de direitos, bem como as maneiras e 
os mecanismos para efetivá-los, vá sendo modificada. Mesmo que se tenha uma compreensão "naturalista" dos direitos humanos, ainda assim se pode perceber a presença da historicidade, pois o sentido de natureza humana que lhe dá base vai recebendo influências e modificações. Admitir a historicidade é não partir da ideia de que os direitos são absolutos e, por isso, imodificáveis, o que levaria a uma postura que poderia contrastar com a finalidade principal dos direitos humanos, que é proteger a humanidade.

\section{DIMENSÕES DOS DIREITOS HUMANOS}

Os direitos humanos são todos iguais? Por que então se fala em várias listas de direitos? Afinal, se são universais, indivisíveis e interdependentes, por que dizer que existem diversos direitos? Identificar várias dimensões dos direitos humanos pode gerar classificação dos direitos. Isso, no entanto, em hipótese alguma pode significar determinar maior ou menor importância a uns ou a outros. Também não pode significar endossar uma leitura geracional evolucionista pela qual alguns direitos, por terem sido reconhecidos antes do que outros, já teriam sido superados pelos que vieram depois ou então têm mais importância.

\subsection{Direitos Civis e Políticos}

Os direitos civis e políticos estão presentes na Declaração Universal dos Direitos Humanos (1948) e foram proclamados pela ONU através do Pacto Internacional dos Direitos Civis e Políticos (PDCP) (1966), ratificados pelo Brasil em 1992 e também, entre outras, através da Declaração sobre a Proteção contra Tortura e outros Tratamentos ou Penas Cruéis, Desumanos ou Degradantes (1975).

Em termos gerais, poderíamos dizer que são aqueles direitos relativos às garantias e liberdades fundamentais. Apesar da dificuldade de consenso sobre sua classificação, poderíamos dizer que os direitos civis são, entre outros, o direito: ao reconhecimento e igualdade diante da lei; a um julgamento justo; 
de ir e vir; à liberdade de opinião, de pensamento e de religião. Os direitos políticos, entre outros, são o direito: à liberdade de reunião; à liberdade de associação; à participação na vida política. Muitos consideram que esses são os direitos individuais por excelência e que constituem garantias absolutas contra o Estado - direitos de prestação negativa.

O conceito atual de direitos humanos indica que não é suficiente essa concepção, já que os direitos civis e políticos implicam também responsabilidades do Estado na sua garantia, sem que isso diminua a responsabilidades de cada pessoa.

\subsection{Direitos Econômicos, Sociais e Culturais}

Os direitos econômicos, sociais e culturais estão presentes na Declaração Universal dos Direitos Humanos (1948) e foram proclamados pela ONU através do Pacto Internacional dos Direitos Econômicos, Sociais e Culturais (PIDESC) (1966), ratificados pelo Brasil em 1992.

Em termos gerais, poderíamos dizer que são aqueles direitos que os indivíduos demandam ao coletivo; por isso, acarretam a garantia de condições coletivas e estruturais de desenvolvimento, implicando não somente os indivíduos, mas toda a coletividade. Apesar da dificuldade de consenso na sua classificação, poderíamos dizer que os direitos econômicos são: os direitos a um desenvolvimento autônomo, a um meio ambiente sadio, a alimentação, ao trabalho e os direitos do trabalhador; os direitos sociais são relativos à segurança social, à família, à maternidade e à infância, à moradia e à cidade, o direito à saúde e à educação; os direitos culturais são relativos à participação da vida cultural e do progresso científico. Também incluem os direitos à nãodiscriminação e os direitos das mulheres e de outros grupos sociais vitimizados.

Muitos consideram esses direitos como sendo aqueles cuja ação do Estado deveria ser determinante para sua garantia - direitos de prestação positiva. O conceito atual, novamente, assim como no caso dos direitos civis e políticos, exige compromissos tanto do Estado quanto da cidadania. 
40. Esses direitos são de realização progressiva, o que não significa, em hipótese alguma, admitir retrocessos.

\subsection{Direitos Coletivos e de Solidariedade}

Também são conhecidos como direitos coletivos, meta-individuais, difusos ou de solidariedade. Os instrumentos internacionais que contêm estes direitos são: Declaração sobre Meio Ambiente e Desenvolvimento (1992), Declaração sobre Direito ao Desenvolvimento (1986), Declaração sobre Direitos dos Povos à Paz (1984), a Convenção sobre os Direitos da Criança (1990), a Convenção sobre a Eliminação de Todas as Formas de Discriminação contra as Mulheres (1983), a Convenção sobre Eliminação de Todas as Formas de Discriminação Racial (1967), a Convenção sobre Direitos das Pessoas com Deficiência (2006), a Declaração dos Direitos dos Povos Indígenas (2007) e vários outros.

Caracterizam-se por serem direitos que não têm titularidade individual e também não regulam a relação dos indivíduos com o Estado. São direitos públicos no sentido profundo do termo. Em geral, formam aquele conjunto de direitos que dizem respeito à garantia de um meio ambiente social e natural na perspectiva da proteção, preservação e recuperação das condições naturais pelo uso sustentável dos recursos naturais, ao desenvolvimento, à paz e à autodeterminação dos povos. Também incluem os direitos à proteção de grupos e segmentos e os direitos relacionados ao consumo.

Há ainda um conjunto de outros direitos que estão em disputa por reconhecimento e que poderiam ser chamados de "novíssimos" direitos. Trata-se dos direitos que protegem a vida humana e poderiam ser chamados de bioéticos, dos direitos advindos da realidade virtual e das tecnologias de informação (internet, por exemplo), além do debate sobre os direitos dos animais. Esse conjunto de direitos vem sendo discutido e já há instrumentos internacionais, porém ainda sem abrangência ampla como no caso dos demais. 
A quem cabe respeitar e reconhecer os direitos humanos? Ora, a todas as pessoas cabe respeitar e reconhecer os direitos humanos. Não por razões egoístas, ou seja, para que seus próprios direitos sejam respeitados e reconhecidos. Cabe a cada um(a) o dever de respeitar e reconhecer os direitos dos outros simplesmente porque os outros são seres humanos.

Esse compromisso não existe somente em relação a certos tipos de seres humanos, os "de bem", mas de todas as pessoas. Essa ideia de querer separar as pessoas, distinguindo aquelas que são boas das que não são é um discurso falso. Pior, a história nos mostra as consequências: foi isso que justificou o totalitarismo do nazismo e do fascismo que matou milhões de judeus; foi o que justificou a escravidão dos negros africanos na América e no Brasil; é isso que continua justificando a discriminação dos negros, das mulheres, dos homossexuais. Enfim, são pensamentos que acham que há certos tipos de gente mais gente do que outros que levaram e continuam levando ao desrespeito às pessoas, à falta de reconhecimento e de compromisso com os direitos humanos. Não se pode invocar os direitos humanos de uns poucos, por melhores que sejam, contra os direitos dos outros, sob qualquer argumento, sob pena de na verdade transformar direitos em conteúdo que depõe contra os direitos humanos.

Os direitos humanos não são somente para os "humanos direitos"; os direitos humanos são direitos de todos os seres humanos simplesmente porque são humanos. Superar posturas discriminatórias é o primeiro passo para se comprometer com a realização desses direitos.

Mas todos têm as mesmas responsabilidades com os direitos humanos? Sim, a responsabilidade é de todos, mas o tipo de responsabilidade é diferente. A uma pessoa individualmente cabe reconhecer o outro ser humano como sujeito de direitos, não agredindo e nem discriminando e, acima de tudo, respeitando-o em sua dignidade.

As organizações e movimentos sociais são agentes fundamentais no processo de luta por direitos, seja para criar novos direitos, seja para fazer com que aqueles que foram institucionalizados deixem de ser "letra 
morta" e se transformem em ação, em políticas públicas. As organizações e movimentos sociais populares têm a tarefa de mobilizar as pessoas e articular suas lutas para apresentar agendas novas e renovadas de direitos; para prestar atenção, vigiar, controlar, monitorar para que nem indivíduos, nem empresas e nem o poder público violem os direitos e, mais do que isso, para propor alternativas para avançar na efetivação dos direitos.

O Estado também é agente de garantia, promoção, proteção e realização dos direitos humanos de todas as pessoas e também de reparação das violações. O poder público, nas suas diversas esferas e poderes, tem a responsabilidade de atender às demandas sociais, de regular as relações e de gerar mediações de tal forma a garantir que os direitos sejam realizados e as violações sejam evitadas e, quando ocorrerem, sejam reparadas. A institucionalidade justa é aquela que tem nos direitos humanos não um recurso a mais, mas como conteúdo e método central de ação. Os direitos humanos não são somente uma finalidade a ser atingida com esforço, são exigências de constituição de mediações; portanto, de relações efetivas que também sejam pautadas por eles.

As empresas e grupos privados não podem transformar sua vocação para o lucro e a apropriação privada dos bens públicos em instrumentos de violação dos direitos. Cabem-lhes responsabilidades no sentido de cumprir a lei e respeitar os direitos humanos como qualquer outro agente. Os agentes econômicos não estão dispensados dos compromissos com os direitos humanos. Assim, contando com o compromisso de diversos agentes, os direitos humanos podem se tornar realidade. Até porque nenhuma pessoa e nenhuma instituição, organização ou agente econômico tem o direito de violar os direitos humanos. Os direitos humanos não estão disponíveis para serem violados. Pelo contrário, são parte da ação comum, compromisso de todos e de cada um. É por isso que nenhuma justificativa para a violação dos direitos humanos pode ser legítima e muito menos deveria ser legal. 


\section{REFERÊNCIAS}

CARBONARI, Paulo César. Direitos humanos: sugestões pedagógicas. Passo Fundo: IFIBE; Brasília: SDH, 2014.

. Realização dos direitos humanos. Passo Fundo: IFIBE, 2006a.

CARBONARI, Paulo César (Org.). Sentido filosófico dos direitos humanos: leituras do pensamento contemporâneo. Passo Fundo: IFIBE, 2006b. v. 1.

_._. Passo Fundo: IFIBE, 2009. v. 2.

.__. Passo Fundo: IFIBE, 2013. v. 3.

CDHPF. Direitos humanos desde Passo Fundo. Passo Fundo: CDHPF, 2002.

CPT; FIAN; MNDH. Direitos Humanos Econômicos: seu tempo chegou. Goiânia: CPT; FIAN; MNDH, 1997.

HERRERA FLORES, Joaquin. A (re)invenção dos direitos humanos. Trad. C.R.D. Garcia et al. Florianópolis: Fundação Boiteux; IDHID, 2009.

IIDH. Protección de derechos humanos. 2. ed. San José: IIDH, 2002.

MÜHL, Eldon et al. (Org.). Textos referenciais para a educação em direitos humanos. Passo Fundo: IFIBE; FAED/UPF; CDHPF, 2009.

SILVEIRA, Rosa Maria Godoy et al. (Org.). Educação em direitos humanos: fundamentos teóricometodológicos. João Pessoa: UFPB, 2007.

WOLKMER, Antônio Carlos. Direitos humanos: novas dimensões e novas fundamentações. Revista Direito em Debate, Ijuí, n. 16-17, p. 9-32, jan./jun. 2002. 



\section{CIDADANIA E DIREITOS HUMANOS: PARA TODOS OU PARA ALGUNS?}

\section{Denise Dourado Dora}

Em 1823, o Diccionario da Língua Portugueza conceituava o cidadão como "o homem que goza dos direitos de alguma cidade, das isenções, e privilégios, que se contêm no seu foral, posturas", ou "o vizinho de alguma cidade", ou, ainda, o "homem bom" (Santos; Ferreira, 2009, p. 44); ou seja, remetia a definição de cidadania à ideia de pertencimento a uma cidade. Os direitos humanos ou "direitos do homem"1 partem de uma sucessão de conceitos, dos direitos naturais aos direitos do homem e dos direitos do homem aos direitos humanos, a partir dos séculos XVII e XVIII na Europa. Inicialmente, como distinção do que era divino ou animal, direitos humanos e direitos do homem passam a ser utilizados ao lado de direitos de cidadãos (Hunt, 2009).

Portanto, cidadania e direitos humanos são ideias com significados muito aproximados, que surgem a partir de uma experiência humana histórica associada às grandes transformações ocorridas na passagem da Idade Média para o período moderno, especialmente na Europa, e que acaba expandindo-se para outros continentes. Hoje há vários esforços para entender e identificar quando, onde e como estes conceitos começam a ser

1 A linguagem tem gênero; chamar de "direitos do homem" já demonstra que, nos seus primórdios, os direitos humanos eram destinados a homens, excluindo mulheres, crianças e escravos. 
utilizados, e como se transformaram e criaram novos significados a partir de contextos diferentes.

Especialmente na história brasileira recente, cidadania e direitos humanos aparecem muito frequentemente associados, como se fossem mesmo uma só ideia ou conceito. "Esta é uma questão de cidadania e direitos humanos" parece ser uma frase muito comum de se ouvir em variados ambientes, tanto políticos e sociais quanto acadêmicos; convites para "seminários sobre cidadania e direitos humanos" também fazem parte do cotidiano dos movimentos sociais e organizações não governamentais, indicando que há uma forte inter-relação entre ambos os conceitos.

$\mathrm{Na}$ verdade, a combinação dos conceitos de direitos humanos e cidadania existe como uma adição de significados para reforçar a noção de que pessoas têm direitos e os governos têm deveres. Vamos analisar o percurso histórico dessa ideia.

\section{CIDADANIA}

Embora se possam encontrar referências de exercício de cidadania já na Antiguidade ocidental, em especial na Grécia e em Roma, vamos refletir sobre a experiência moderna de cidadania, fundada a partir do século XVIII. Em 1823, cidadão era "o homem que goza dos direitos de alguma cidade, das isenções, e privilégios, que se contêm no seu foral, posturas", ou "o vizinho de alguma cidade", ou, ainda, o "homem bom" ${ }^{2}$. Cidadania era muito ligada à ideia de território, cidade, vizinhança, e foi desta forma que as primeiras experiências de cidadania se revelaram. Conforme Santos e Ferreira, na passagem da Idade Média para a Idade Moderna os conceitos de vizinho e cidadão eram muito semelhantes, definidos por um "estatuto jurídico que definia o pertencimento de um indivíduo à comunidade local em termos de privilégios, deveres, isenções e costumes” (2009, p. 45). Assim, as primeiras noções de cidadania ainda estavam atreladas a uma ordem política e econômica medieval e foi o processo de mudanças políticas

\footnotetext{
2 Dicionário Houaiss.
} 
e sociais no século XVIII que permitiu a passagem desta compreensão hierárquica para uma de fundo mais igualitário. Esse processo acontece devido a vários fatores, mas especialmente dois são mais relevantes: o surgimento de uma forte noção de indivíduo como sujeito de direitos, e a construção dos Estados-nação.

O movimento de construção de identidades individuais, de uma pessoa que passa a se diferenciar um pouco de sua família e/ou comunidade, vai demarcar a passagem de sociedades tradicionais, baseadas em valores comunitários e religiosos, para sociedades modernas. Nessa passagem que percorre o mundo medieval por vários séculos há uma mudança profunda em relação às noções de integridade corporal, redefinição do espaço doméstico, da casa, dos cômodos, dos conceitos de higiene, da autoridade parental e das tradições familiares. Essa redefinição do uso do espaço físico e das relações pessoais leva a uma redefinição das relações com o poder constituído (Hunt, 2009, p. 28); de fato, essas profundas modificações no modo de vida têm implicações decisivas para reorientar a relação dos indivíduos com o país, com a nação e com seus direitos. É nesse momento de passagem do século XVII para o século XVIII que se desenvolve um forte sentimento de pertencimento a um país e de crescente interesse em participar e definir os rumos da política.

O conceito de indivíduo como motor da sociedade emerge do ambiente cultural do Renascimento europeu no qual a pessoa "renasce" em uma ordem econômica diferente com ideias de privacidade, passando da experiência de uma família coletiva para a vida mais solitária, e, por decorrência, solidária. Essa é a experiência histórica fundamental que permite enxergar o outro como outro, desenvolver empatia e solidariedade e criar alicerces para noções de igualdade e fraternidade que levam aos direitos fundamentais. Muitos autores afirmam que a cidadania moderna surge com as revoluções inglesa, americana e francesa do século XVIII, relacionadas à luta pela construção de uma nação com indivíduos livres e autônomos, os cidadãos. Portanto, o processo de construção de noções de indivíduos convive e dá elementos para uma nova concepção política de pertencimento a uma nação, a uma 
ordem de direitos e deveres e a um Estado que organiza a vida em sociedade (Mondaini, 2003).

O estabelecimento de Estados-nação é, portanto, uma invenção do mundo moderno que redefine a organização política de um país a partir dos elementos de território, língua comum (oficial) e leis que atingem todas as pessoas desse Estado. A experiência das revoluções acima mencionadas gerou um grande debate intelectual sobre noções de poder, criação de instituições e participação da sociedade a partir de critérios racionais e não mais baseados em tradições religiosas ou hierarquias comunitárias. Trata-se de uma disputa com os conceitos medievais, com o poder religioso anterior; em especial, a partir da ideia de que o poder não é natural e divino, mas sim decidido pelas pessoas.

Mesmo as bandeiras da Revolução Francesa - igualdade, liberdade e fraternidade - são bandeiras que surgem para responder e transformar uma sociedade feudal, fixa em castas e segmentos sociais na qual não havia mobilidade; com o avanço do conceito de indivíduos com direitos, essa estrutura de poder precisa ser modificada e é modificada com processos políticos de ruptura violenta com antigos regimes, rearranjo de forças e construção de novos modelos de governo.

As revoluções do século XVIII consolidam então as concepções de que os indivíduos nascem livres e iguais e que a garantia destes direitos é dada por um Estado nacional, no qual os direitos passam a ser regulados por lei. Esse Estado moderno necessita de uma autoridade central, um poder concentrado com monopólio da força mediante a lei. Ser cidadão nesse contexto é ter nacionalidade, é fazer parte de um Estado que protege seus direitos. E a palavra cidadão, como mencionado na introdução, remete à ideia de cidade. Por quê? Porque é a cidade que surge como definidora do espaço público; os direitos se exercem na cidade e não no campo; eis que o campo remetia ao mundo feudal, dos servos, dos sem direito, era um espaço da tradição. É, portanto, na cidade que estes novos direitos podem ser realizados, nas disputas entre setores econômicos e políticos e de afirmação de direitos. 
Pensar em cidadania é então refletir sobre esse primeiro marco de instalação de uma cidadania moderna, no qual os fatores constitutivos são o nascimento de um indivíduo com autonomia, de leis que regulam a vida em sociedade e de um Estado que se responsabiliza por implementar estas leis e proteger seus cidadãos. Entretanto, desde esse marco inicial, a noção de cidadania não foi inclusiva em relação ao povo a qual se dirigia, o que não é surpreendente. Saindo de uma sociedade marcada por hierarquias fortes, com exclusão econômica e política de camponeses, mulheres, crianças, estrangeiros e servos, ou seja, a maioria da população, essa construção de cidadania foi primeiramente dirigida a homens com propriedade e educação. As pessoas "livres e iguais" tinham, portanto, endereço certo; eram as novas elites econômicas que reorganizavam seus espaços de poder.

Essa nova organização da vida em sociedade não se deu sem conflitos intensos, ganhos e perdas, inclusive entre os setores que desejavam mudanças. Por exemplo, as mulheres do povo francês foram mobilizadas para participar da Revolução, mas da elaboração da Declaração dos Direitos do Homem e do Cidadão elas foram excluídas. Esse fato leva a uma forte crítica das lideranças femininas e inclusive à execução de várias delas, entre as quais Olympe de Gouges é a mais conhecida (Perrot, 1997). Como a história é um motor em constante movimento, a construção da cidadania moderna vai então passar por diversos confrontos e fases em que esses desafios de inclusão e participação, além da capacidade de garantir direitos por parte do Estado, vão ir redefinindo seus contornos.

T. H. Marshall, em seu artigo Cidadania e Classe Social (1967), mostra que houve um encadeamento lógico a partir da noção de direitos individuais e civis, em que as pessoas - em especial, os cidadãos - passavam a contar com a prerrogativa de ter suas vidas reguladas por leis e não por critérios arbitrários das hierarquias tradicionais. A vontade do senhor feudal, do duque ou do rei passa a ser substituída por um conjunto de normas que regulam a vida e protegem os indivíduos. Para sustentar o exercício desses direitos desenvolveram-se instituições, parlamentos e cortes judiciais. Esse modelo de cidadania poderia estar completo se não houvesse desigualdade econômica e social. As imensas desigualdades sociais criam obstáculos para o exercício 
desses direitos por parte de uma grande parcela da população, totalmente à margem desse sistema de direitos. Isso leva a demandas e lutas políticas por direitos sociais que exigem do Estado um conjunto de políticas de proteção social e novas instituições que possam reduzir as desigualdades e dar soluções a esses conflitos.

A cidadania precisa caminhar ao lado da democracia; eis que o encadeamento positivo de direitos, leis e instituições só é potencializado em Estados que realmente ouvem seus cidadãos, mas exige reconhecer as desigualdades econômicas e de poder (Reis, 1998). A cidadania, para que tenha efeitos substantivos, deve ser exercida por sujeitos em condições de paridade. A pobreza e as desigualdades educacionais excluem do exercício de direitos, assim como as discriminações contra grupos específicos também ameaçam e mesmo impedem a efetividade dos direitos. Como mencionado anteriormente, desde a Revolução Francesa há uma crítica feminista à noção limitada de cidadania; eis que o processo político e histórico de definição de cidadania construiu modelos de cidadão que excluía as mulheres de direitos civis e políticos básicos, como votar e ser votada, ter autonomia jurídica, receber herança e outros. Não por acaso, vários dicionários ainda mencionam "cidadão" como "o homem bom". A exclusão das mulheres e a escravidão de africanos e indígenas nos séculos XVIII e XIX são, sem dúvida, os limites óbvios dessa cidadania moderna, cuja promessa de igualdade não se realiza em muitos lugares pela permanência de desigualdades econômicas e sociais, heranças de preconceitos arraigados e discriminações estruturais. Como os indivíduos não são iguais e dessa forma não correspondem aos modelos tradicionais de cidadãos, há o desafio de atualização dos conceitos de cidadania e de sua efetividade. Reconhecer essas singularidades é condição para cidadania que, além de direitos formalmente normatizados, exige políticas e solidariedade social.

Outro fator que hoje desafia os conceitos clássicos de cidadania é a crescente integração de países e de culturas. O processo de integração econômica em larga escala leva a um comércio realmente global, com trânsito de capitais, empresas e pessoas. O processo de integração política e cultural tem alterado o cenário das políticas nacionais, passando a haver cada 
vez mais instituições, leis e procedimentos transnacionais. A globalização produz uma transição da concepção eminentemente nacional de cidadania para uma concepção de cidadania transnacional e continental. Esse é um fenômeno muito recente e que vai levar à necessidade de reflexão sobre o lugar no qual se produzem e se realizam os direitos de cidadania, considerados até então como direitos produzidos no âmbito dos Estados nacionais e implementados através de políticas por estes mesmos Estados. Esse debate nos leva a pensar sobre como e quando se estabelecem os direitos humanos com um caráter universal e sua relação com os direitos e o exercício da cidadania tradicionalmente exercidos desde o século XVIII.

\section{DIREITOS HUMANOS}

A ideia de que as pessoas têm direitos pelo simples fato de serem humanas pode ser encontrada em distintos períodos da história da humanidade, presente em doutrinas religiosas, filosofias, noções de respeito à lei, enfim, formas de organização de diferentes sociedades que remetem a uma ideia de direitos. Portanto, assim como cidadania, a expressão "direitos humanos" tem uma história que pode ser rastreada no tempo, mas que se cristaliza como afirmação de direitos humanos no final do século XVIII (Hunt, 2009, p. 18-19).

Thomas Jefferson, em 1776, ao rascunhar a Declaração de Independência Americana escreve que: "Consideramos estas verdades autoevidentes: que todos os homens são criados iguais, dotados pelo seu criador de certos direitos inalienáveis, que entre estes estão a Vida, a Liberdade e a busca da Felicidade" (Hunt, 2009, p. 13). Em 1789, o rascunho da Declaração Francesa dos Direitos do Homem e do Cidadão falava dos "direitos naturais, inalienáveis e sagrados do homem”. Esses dois documentos estavam diretamente relacionados à inauguração de uma nova ordem política em um contexto determinado, mas a linguagem presente nas duas Declarações acabou por transformá-las em documentos mais duradouros e mesmo universais ao propor uma ideia revolucionária: a da igualdade entre as pessoas. 
52 Essa noção de igualdade foi depois estabelecida em várias constituições nacionais, ficando claro então quem eram os beneficiários desta igualdade na prática e como mulheres, crianças, pessoas consideradas insanas, ciganos, estrangeiros e escravos africanos estavam fora do alcance dos direitos (Hunt, 2009). Posteriormente, houve um esforço do governo francês quando, em 1791, concede direitos aos judeus, em 1792 aos homens sem propriedade e em 1794 abole a escravidão (Hunt, 2009). Outro exemplo eloquente é a abolição da escravatura em todos os países ocidentais, sendo o Brasil o último a fazê-lo em 1888 .

Estabelecidos direitos de cidadania, as duas Guerras Mundiais, as independências africanas e asiáticas e as lutas contra ditaduras latinoamericanas no século XX colocam novos desafios. Os direitos, segundo alguns, não passam de uma expressão da vontade do Estado e, portanto, podem ser modificados e reduzidos se isto interessar ao Estado. Essa interpretação vai contribuir para uma relação instrumental com os direitos humanos e possibilitar a emergência e legitimação de regimes autoritários. Por exemplo, na Alemanha Hitler é eleito e vislumbra a possibilidade de realizar os fins do nazismo utilizando-se dos mecanismos formalmente estabelecidos pela Constituição. Dessa forma, o direito neutro serve de instrumento para um Estado nazista (Vieira, 2006). Um dos primeiros atos de Hitler foi destituir diversos grupos do seu status de nacionais. Os judeus foram os primeiros a ser desnacionalizados. Como não tinham mais vínculos com o Estado alemão e como não havia relações jurídicas que os ligassem a qualquer outra esfera de proteção de direitos, eles encontravam-se excluídos moral e juridicamente do sistema de proteção de direitos. Excluídos, judeus, ciganos, comunistas, homossexuais e outras minorias ficaram totalmente vulneráveis e passaram a ser tratados como objeto e não como sujeito de direitos, como descreve Hannah Arendt (Lafer, 1988).

Dessa forma, uma reinterpretação das noções de direitos fundamentais em um novo contexto político propiciou uma série de fatos que levam à II Guerra Mundial, quando milhões de pessoas foram assassinadas por seus próprios Estados, que deveriam ter a função primordial de protegê-las. A II Guerra Mundial (1939-1945) se diferencia das demais exatamente 
pelo fato de que as principais vítimas foram nacionais mortos pelos seus próprios Estados. No período que vai de meados dos anos 1930 até o final da II Guerra morreram cerca de 45 milhões de pessoas. Mais da metade desses mortos não foram soldados vitimados em combate, mas civis mortos pelos seus próprios Estados, principalmente na Alemanha e na União Soviética. Então esses mais de 20 milhões de seres humanos foram vítimas da instituição que a princípio deveria protegê-los. Esse é um fato novo e incompatível com os princípios de criação dos Estados modernos, que poderiam até ter cidadanias excludentes, mas que não assumiam um papel proativo no extermínio de seus próprios cidadãos. O Estado utilizando noções de direito formal e provocando a morte de grupos raciais, religiosos e dissidentes políticos, numa escala assustadora, é algo peculiar ao período da II Guerra (Hobsbawn, 1994).

Essa experiência de erosão de direitos que se materializou na II Guerra e o receio de outra guerra mundial com efeitos ainda mais devastadores cria a necessidade de construção de uma instituição transnacional com legitimidade para redefinir um corpo de direitos e responsabilidades dos Estados nacionais. Surge então a Organização das Nações Unidas, criada por 51 países em 1945, e a Declaração Universal dos Direitos Humanos, aprovada pela Assembleia Geral das Nações Unidas em 10 de dezembro de 1948.

Durante 200 anos, a Declaração Francesa foi a principal referência para um discurso sobre direitos humanos universais, mas foi com a aprovação da Declaração Universal em 1948 que essa promessa se materializa ao afirmar que "Todos os seres humanos nascem livres e iguais em dignidade e direitos" (Art. $1^{\circ}$ ) e que "Todo ser humano pode fruir de todos os direitos e liberdades apresentados nesta Declaração, sem qualquer distinção de raça, cor, sexo, língua, religião, opinião política ou de outra ordem, origem nacional ou social, bens, nascimento ou qualquer outro status" (Art. $2^{\circ}$ ). O longo período que separou a Declaração Francesa (1789) da Declaração Universal (1948) não é desprovido de leis de proteção a direitos, mas essas são basicamente nacionais. São constituições e leis nacionais que trataram dos direitos de categorias profissionais, grupos específicos e procedimentos 
estatais. A ideia dos direitos universais realmente só ganhou protagonismo a partir da necessidade de uma reação à violência contra seres humanos que foram perpetrados pelos Estados durante a II Guerra.

Logo após a sua criação, a ONU constituiu uma comissão para elaborar uma declaração universal de direitos humanos da qual fizeram parte, entre outros, Rene Cassin e Eleonor Roosevelt, representando respectivamente a França e os Estados Unidos. Essa comissão, que também contava com um representante libanês e um chinês, elaborou um documento que serviu de base para o debate na Assembleia Geral da ONU e foi aprovado em 1948. A Declaração Universal tem 30 artigos que tratam de direitos individuais, civis, políticos, sociais, econômicos e culturais e também um dispositivo que estabelece que nada na Declaração deve ser interpretado de forma a autorizar qualquer Estado, grupo ou pessoa a se engajar em atividade que violem direitos humanos (Glendon, 2001).

A Declaração Universal dos Direitos Humanos é aprovada como um marco ético e político pela qual a comunidade internacional deve zelar e os Estados nacionais devem seguir, mas não teve efeitos jurídicos imediatos. Foi o uso regular e constante dos artigos da Declaração nos últimos 60 anos, seja por terem sido adotados em Constituições e leis nacionais, mencionados em decisões judiciais sobre violações de direitos humanos e em pesquisas e publicações sobre o tema que fez com que a Declaração fosse progressivamente sendo incorporada ao arcabouço jurídico internacional (Piovesan, 1998). Muitas constituições nacionais elaboradas depois de 1948 incorporam formalmente os princípios e artigos da Declaração como preceitos jurídicos locais; isso acontece na África pós-colonial, na América Latina e países europeus, como Portugal e Espanha. A Constituição Brasileira de 1988 é um exemplo precioso desta incorporação jurídica dos princípios da Declaração (Vieira, 2006)

A Declaração também produziu efeitos no debate sobre autodeterminação dos povos, o que levou a uma expansão do debate sobre a independência de países africanos e de suas lutas políticas a partir dos anos 50 e criou bases morais ainda mais sólidas para a expansão do feminismo no mundo. Portanto, a Declaração surgida em um momento histórico de 
construção de novos consensos é, ao mesmo tempo, a cristalização de um longo caminho desde as revoluções do século XVIII e o início de uma nova época para a defesa dos direitos humanos. Conforme Lynn Hunt, "a Declaração Universal é mais o início do processo do que o seu apogeu” (Hunt, 2009, p. 209), e vai influenciar todo o movimento político no mundo pós II Guerra Mundial.

Do ponto de vista interno da Organização das Nações Unidas, o debate sobre direitos humanos segue depois de 1948. Sendo a primeira vez que uma "lista" de direitos é elaborada para ter caráter universal e considerando o ambiente da Guerra Fria nos anos 50 e 60, uma forte controvérsia é mantida dentro da ONU em relação à natureza desses direitos e à obrigação dos Estados em cumpri-los. Assim, em 1966, dois Pactos de Direitos Humanos são aprovados; um tratando dos Direitos Civis e Políticos e outro dos Direitos Econômicos, Sociais e Culturais, que respondem à divisão existente entre União Soviética, China e demais países comunistas e os Estados Unidos, Inglaterra e países “ocidentais”. De qualquer forma, esses pactos cumprem um papel muito importante, pois tratam de arrolar com mais precisão os direitos humanos e estabelecem os mecanismos de adesão dos Estados nacionais a obrigações jurídicas internacionais. Um país, para aderir ao pacto, deve ter aprovação do parlamento e do governo executivo, o que exige um debate nacional. Hoje, 164 nações fazem parte do Pacto de Direitos Civis e Políticos e 160 do Pacto de Direitos Econômicos, Sociais e Culturais, sendo sua mais notável exceção os Estados Unidos da América.

Nos últimos 60 anos, a ONU também aprovou Convenções Internacionais sobre diversos temas específicos, como a Convenção para Eliminação do Racismo, a Convenção para Eliminação da Discriminação contra a Mulher, a Convenção para Abolição da Tortura e Tratamento Degradante, a Convenção dos Direitos da Criança, entre outras. Cada Convenção criou um sistema de monitoramento da aplicação de seus preceitos pelos Estados membros da ONU; assim, há comitês especializados em requerer relatórios dos governos sobre o cumprimento das normas da Convenção, realizar audiências públicas e ouvir a sociedade civil dos diversos países. A partir dos anos 1960, a ONU estabeleceu procedimentos para 
denúncias que "aparentemente revelam um padrão consistente, repulsivo e confiavelmente atestado de violações de direitos humanos", ou seja, "graves violações de direitos humanos". Nessas situações, o Estado estaria violando obrigações contraídas com a Carta e poderia, assim, sofrer investigações, repreensões e mesmo sanções por parte da comunidade internacional (Vieira, 2006).

Fora da esfera das Nações Unidas e dos governos, a sociedade de diversos países passa a se organizar no âmbito local e também global através da criação de diversas organizações não governamentais, como a Anistia Internacional, criada em 1961, que dão voz a vítimas de violações no mundo inteiro. Em 1993, a ONU, como parte de seu ciclo de conferências mundiais, realiza a Conferência Mundial de Direitos Humanos em Viena, que recomenda a criação de um Alto Comissariado para Direitos Humanos e do Tribunal Penal Internacional, a partir das experiências dos Tribunais de Ruanda e da Ex-Iugoslávia. Em 1994, é criado o Alto Comissariado de Direitos Humanos e, em 1998, é criado o Tribunal Penal Internacional, que tem competência para julgar crimes de genocídio, crimes contra a humanidade e crimes de guerra, fortalecendo assim o sistema das Nações Unidas (Vieira, 2006).

Paralelos a esses esforços institucionais na Organização das Nações Unidas também houve desenvolvimentos no âmbito dos continentes. A Europa, a América e, mais recentemente a África desenvolveram seus sistemas de proteção aos direitos humanos dentro de suas estruturas institucionais regionais, como a Organização dos Estados Americanos e a União Europeia. Os sistemas regionais são fundados a partir de tratados internacionais que definem normas jurídicas e criam sistemas de monitoramento e julgamento de casos, como as Comissões e as Cortes de Direitos Humanos.

O sistema interamericano de direitos humanos foi estabelecido a partir de 1948, com a adoção da Declaração dos Direitos e Deveres do Homem pela Organização dos Estados Americanos. Em 1959, a OEA criou a Comissão Interamericana de Direitos Humanos para acompanhar a situação de direitos humanos no continente. Dez anos depois, em 1969, é aprovada a 

apenas em 1978, com consequências jurídicas de tratado internacional ${ }^{3}$. Quando da aprovação da Convenção Interamericana, é criada a Corte Interamericana de Direitos Humanos, e a Comissão de Direitos Humanos passa a ter novas funções, o que lhe permite ocupar um espaço relevante no monitoramento de violações de direitos humanos durante os regimes autoritários e ditatoriais na América Latina nas décadas de 1970 e 1980. É notória a visita in loco que a Comissão de Direitos Humanos da OEA fez à Argentina durante o regime repressivo que ensejou milhares de denúncias contra torturas e desaparecimentos, até então represadas pela ditadura.

A Comissão Interamericana organiza audiências temáticas, analisa relatórios de países, recebe denúncias individuais e faz investigações in loco, ouvindo testemunhas e coletando evidências. Na verdade, a Comissão funciona como o local de reclamação de cidadãos e cidadãs em relação a seus Estados. Se um país não cumpre com o disposto nas convenções de direitos humanos e não faz nada para reparar o dano causado, pode ser denunciado no sistema internacional de direitos humanos, regional ou global.

A sociedade civil organizada dos mais diversos países costuma usar estratégias combinadas, que vão da elaboração de relatórios, demonstrando o caráter regular de determinadas violações que configuram um padrão de desrespeito aos direitos humanos, a casos individuais no qual há provas evidentes de abuso. Por exemplo, o uso de tortura no sistema prisional no Brasil que já foi objeto de várias denúncias através de organizações como Justiça Global, Conectas ou Movimento Nacional de Direitos Humanos, que se utilizaram de variados mecanismos como audiência temáticas, relatórios, apresentação de casos e convite para visitas da Comissão a presídios brasileiros. Um desses casos, o do presídio Urso Branco em Rondônia, resultou no pedido de intervenção federal no estado por continuado abuso aos direitos humanos.

\footnotetext{
3 Existe uma diferença entre declaração e convenção no âmbito do direito internacional, sendo que a declaração é considerada uma carta de princípios e de intenções a que os Estados aderem de forma política, e as convenções são realmente leis internacionais que exigem procedimentos técnico-jurídicos para a adesão dos Estados. A ratificação de um Estado membro à convenção passa a vinculá-lo juridicamente, podendo inclusive receber sanções pelo seu descumprimento.
} 
Outro caso conhecido no Brasil foi o da farmacêutica Maria da Penha, que foi vítima de severa violência doméstica e tentativa de homicídio e não teve por parte das instituições públicas brasileiras nenhuma resposta, seja na investigação ou condenação do agressor. Após mais de uma década sem solução, Maria da Penha, que ficou paralítica em função das agressões, entrou com uma petição individual na Comissão Interamericana de Direitos Humanos, afirmando que o governo brasileiro nada fazia efetivamente para proteger suas cidadãs contra a violência doméstica. $O$ governo brasileiro foi instado a investigar e punir o agressor e condenado a pagar uma indenização e rever sua legislação e política para contemplar medidas de proteção à vida e integridade das mulheres ${ }^{4}$.

A decisão do caso Maria da Penha levou efetivamente à mudança da legislação nacional com a adoção da Lei Maria da Penha de prevenção e combate à violência contra as mulheres que cria, entre outras medidas, juizados especiais para investigação e punição de agressores.

Em 60 anos, partiu-se de uma Declaração de direitos para a existência de tratados jurídicos internacionais e instituições criadas para implementálos. Esse arcabouço de leis e instituições tem muitos limites para exercer suas funções - desde questões de legitimidade até de sustentabilidade -, mas sem dúvida se criou uma possibilidade, antes inexistente, de que cidadãos e cidadãs reclamem de seus Estados e não estejam inexoravelmente submetidos a dinâmicas nacionais. Governos, parlamentos e judiciário podem ser criticados em esferas superiores de jurisdição, o que obviamente gera muita controvérsia e exige um trabalho constante de análise e inovação (Piovesan, 1997). A questão que se coloca é se a existência destes procedimentos em escala global impacta sobre as concepções nacionais de cidadania, quais os novos desafios e como se estabelecem as conexões entre as tórias e as práticas na vida real.

Os direitos de cidadania estão relacionados a ser cidadão de um determinado Estado nacional, o que garante prerrogativas, leis e políticas de proteção, assim como responsabilidades e deveres. Ser cidadão e cidadã é ter identidade nacional, poder votar e ser votado, ter acesso a políticas 4 O relatório e a decisão podem ser encontrados em: <www.cidh.oas.org > 
de proteção social e à justiça, pagar impostos e ter documentos oficiais, entre outros. Ter direitos humanos, por outro lado, não está relacionado ou restrito a um Estado nacional ou a uma nacionalidade; pelo contrário, diz respeito a um conjunto de direitos que devem ser respeitados por qualquer pessoa ou Estado, em qualquer lugar do mundo - estão vinculados à condição humana de sujeitos de direitos. Assim, uma brasileira de férias na Espanha não pode emitir um passaporte espanhol, nem se candidatar ou votar nas eleições locais, mas pode e deve ter a proteção do Estado espanhol em casos de violência ou risco de vida. Esse é um exemplo que ilustra as diferenças e complementaridades entre direitos de cidadania e direitos humanos. Como afirmam Maia e Pereira,

[...] de modo geral, pode-se dizer que todos os indivíduos pertencentes a um Estado-nação têm direitos e deveres inscritos numa ordem jurídico-política sob a vigência de uma constituição. Com a consolidação das identidades nacionais no século XIX, percebe-se que esses direitos e deveres variam de país para país. Ao contrário dos direitos humanos, que visam a universalidade, na medida em que são direitos da pessoa humana na sua dignidade, a cidadania refere-se especificamente a um Estado (Maia; Pereira, 2009, p. 40).

A cidadania, por estar mais vinculada a um contexto nacional e local, pode ser mais dinâmica eis que o processo de mobilização de um país, ou de um grupo específico de pessoas, em torno de demandas de direitos pode alterar a condição de cidadania de forma mais rápida. As transformações ocorridas no Brasil entre final dos anos 1970 e início dos anos 1980 são evidência dessa dinâmica de mudanças sociais: o país saiu de uma ditadura para um regime civil (1985), alterou sua Constituição Federal (1988), estabeleceu eleições diretas para presidente da República (1989) e renovou seu marco legal. A aprovação de uma nova lei internacional de direitos humanos, por outro lado, exige um processo de mobilização global, com o convencimento 
de vários países, inúmeros debates no âmbito da ONU e pode levar décadas. Entretanto, quando aprovada, essa Convenção ou Tratado reifica os direitos em uma escala universal, para qualquer pessoa em qualquer lugar do mundo. Muitas vezes, a existência de leis internacionais de direitos humanos ajuda a redefinir e ressignificar a cidadania nacional, seja porque funciona como um elemento de resistência à opressão de regimes autoritários, seja como inspiração para o estabelecimento de direitos nacionais.

A combinação dos processos de construção de cidadania nacional com o de definição e expansão dos direitos humanos levanta um grande desafio sobre quem são os sujeitos destes direitos. As exclusões históricas de mulheres, escravos e seus descendentes, crianças, prisioneiros, grupos étnicos, limitam o exercício destes direitos. A obstrução do gozo dos direitos, por exemplo, no acesso à justiça, ou à terra, ou ao direito à saúde, especialmente para grupos que foram e são discriminados pelo Estado e pela sociedade inviabiliza um Estado democrático. O fato de que as instituições funcionam para alguns empoderados econômica e socialmente apenas reproduz o funcionamento de uma sociedade de privilégios, uma sociedade medieval que as noções de cidadania e direitos vieram para transformar. Portanto, a construção de um lugar no mundo para todos, de acesso ao debate político e de expansão da base da cidadania, local ou global, é ainda um grande desafio (Jelin, 2006).

Direitos de cidadania e direitos humanos são diferentes, mas é bom que caminhem juntos. A cidadania, como um processo político, ajuda a democratizar o Estado, a promover mudanças legais, a instaurar políticas públicas, a monitorar sua execução e, neste processo, a fortalecer novas vozes e novos sujeitos. Se esse processo acontece influenciado por um discurso ético de respeito aos direitos humanos, melhor ainda. Teremos, ao final, sociedades menos racistas e mais feministas, menos discriminatórias e mais igualitárias. 
CARVALHO, José Murilo de. Cidadania no Brasil: o longo caminho. Rio de Janeiro: Civilização Brasileira, 2004.

GLENDON, Mary Ann. A World Made New: Eleanor Roosevelt and the Universal Declaration of Human Rights. New York: Random House, 2001.

HOBSBAWN, Eric. A Era dos Extremos, O Breve Século XX 1914-1991, São Paulo: Companhia das Letras, 1996.

HOUAISS, Antonio. Dicionário da Língua Portuguesa. Rio de Janeiro: Editora Objetiva, 2004.

HUNT, Lynn. A Invenção dos Direitos Humanos, uma história, São Paulo: Companhia das Letras, 2009.

JELIN, Elizabeth. Cidadania Revisitada: Solidariedade, Responsabilidade e Direitos. In: Construindo a Democracia: Direitos Humanos, Cidadania e Sociedade na América Latina, São Paulo: EDUSP, 2006.

LAFER, Celso. A reconstrução dos Direitos Humanos: um diálogo com o pensamento de Hannah Arendt. São Paulo: Companhia das Letras, 1988.

LAVALLE, Adrián Gurza. Cidadania, Igualdade e Diferença. Lua Nova: Revista de Cultura e Política, n. 59, 2003.

MAIA, João Marcelo Ehlert; PEREIRA, Luiz Fernando Almeida. Pensando com a Sociologia. Rio de Janeiro: Editora FGV, 2009.

MARSHALL, T. H. Cidadania e Classe Social. In: Cidadania, Classe Social e Status, Rio de Janeiro: Zahar, 1967.

MONDAINI, Marco. O Respeito aos Direitos dos Indivíduos. In: PINSKY, Jaime; PINSKY, Carla. História da Cidadania, São Paulo: Editora Contexto, 2003.

PERROT, Michele. Mulheres Públicas. São Paulo: Editora Unesp, 1997.

PINHEIRO, Paulo Sergio. Os Sessenta Anos da Declaração Universal: atravessando um mar de contradições, in: SUR, Revista Internacional de Direitos Humanos, ano 5, n. 9, São Paulo, 2008.

PINSKY, Jaime; PINSKY, Carla. História da Cidadania. São Paulo: Editora Contexto, 2003.

PIOVESAN, Flavia. O Direito Internacional dos Direitos Humanos e a Redefinição da Cidadania no Brasil. In: Temas de Direitos Humanos, São Paulo: Editora Max Limonad, 1998. 1997.

. Direitos Humanos e o Direito Constitucional Internacional. São Paulo: Editora Max Limonad,

REIS, Elisa Pereira. Sobre a Cidadania. In: REIS, Eliza Pereira. Processos e escolhas, estudos de sociologia política, Rio de Janeiro: Contracapa Livraria, 1998. 

Conceitos Políticos do Brasil, Belo Horizonte: Editora UFMG, 2009.

VIEIRA, Oscar Vilhena. Direitos Fundamentais, uma leitura da jurisprudência do STF. São Paulo: Malheiros Editores, 2006.

; DUPREE, Scott. Reflexões Acerca da Sociedade Civil e dos Direitos Humanos. In: SUR,

Revista Internacional de Direitos Humanos, ano 1, n. 1, São Paulo, 2004. 


\title{
VIOLÊNCIAS E CONFLITUALIDADES NO ESPAÇO ESCOLAR
}

\author{
Rochele Fellini Fachinetto
}

\section{INTRODUÇÃO}

Vivemos num contexto social em que os fenômenos da violência atravessam nosso cotidiano: são imagens, cenas, relatos, notícias, estatísticas, episódios que ocorrem com conhecidos ou ainda quando nós mesmos estamos envolvidos. São inúmeras situações cotidianas veiculadas em jornais, revistas, noticiários, redes sociais, entre outros, em que nos vemos absorvidos e, por assim dizer, assustados, com uma multiplicidade de fenômenos que podem ser caracterizados como violentos e que se manifestam nos mais variados espaços sociais.

De forma geral, é mais comum sermos “capturados” por fenômenos de violência explícita, que possuem uma dimensão material, como os episódios de violência física que deixam no corpo sua marca. Entretanto, para nos acercarmos um pouco mais da complexidade desses fenômenos, torna-se pertinente refletirmos sobre outras formas de manifestação das violências.

Para Zizek (2009, p. 9), num primeiro plano, a violência emerge para nós a partir de seus traços mais evidentes: do crime, do terror, dos confrontos civis e internacionais, mas: 
Deveríamos aprender a ganhar recuo, a desenredarmo-nos do engodo fascinante desta violência "subjectiva" diretamente visível, exercida por um agente claramente identificável. É necessário sermos capazes de nos aperceber dos contornos dos antecedentes que engendram essas explosões. O recuo permitir-nos-á identificar uma violência que subjaz aos nossos próprios esforços que visam combater a violência e promover a tolerância.

O trecho do autor traz alguns aspectos que são fundamentais para iniciarmos a reflexão sobre este tema. O primeiro deles convida a um distanciamento dessa violência explícita, direta, que se torna visível e se utiliza de uma dramatização da dor para sensibilizar, comover e envolver. Essa comoção e envolvimento funcionam como uma "armadilha" ao olhar crítico, pois concentram nossos esforços à dimensão mais explícita e visível da violência - ao horror dos crimes violentos, mortes, torturas e outras tantas violações que acabam limitando nosso posicionamento ao medo, à revolta ou - o que pode ser pior - à própria ideia de vingança e de que algo precisa ser feito agora e já para conter esses episódios. Essa violência explícita, ou demasiadamente explicitada, é para Zizek (2009, p. 9) somente a parte mais visível de um processo que envolve outras formas de violência e que, via de regra, não são tematizadas ou mesmo visibilizadas.

Essa urgência que se coloca diante dos fatos é justamente aquilo que nos impede de fazer uma análise mais aprofundada e cuidadosa dos fenômenos da violência. Somos chamados a nos posicionar e agir imediatamente quando é justamente isso que nos impede de pensar, de refletir e de lançar um olhar analítico sobre a violência, porque estamos demasiadamente envolvidos pelo terror, pela face sangrenta e dolorosa da violência. Essa é uma primeira consideração importante sobre as reflexões que pretendemos pontuar neste texto.

O segundo aspecto a ser destacado com relação ao trecho do autor atenta para a necessidade de olharmos não apenas para uma violência que consideramos externa, distante, longe e fora de nós. Ao contrário, instiga a 
pensar numa violência que subjaz aos nossos próprios esforços que visam combater a violência e promover a tolerância (Zizek, 2009, p. 9). Este se constitui num exercício interessante na medida em que nos faz olhar para diferentes formas pelas quais a violência pode ser manifestar; muitas vezes, a partir de nossas próprias práticas, quando nos dizemos contrários à violência e defensores da tolerância. Há fissuras que nos passam despercebidas e que revelam formas de violência que manifestamos sem nos apercebemos que constituem, elas próprias, também outras formas de violência, porém invisibilizadas.

É justamente nesse sentido que se coloca a importância do recuo e do distanciamento para compreensão de tais fenômenos, pois, ao sermos absorvidos por essa violência explícita, visível, acabamos por desconsiderar outras dimensões que subjazem estas dinâmicas.

Há razões para olharmos obliquamente a violência. A premissa subjacente que parto é a de que há qualquer coisa de intrinsecamente mistificador numa consideração directa: a alta potência do horror diante dos actos violentos e a empatia com as vítimas funcionam inexoravelmente como um engodo que nos impede de pensar (Zizek, 2009, p. 11).

O exercício de distanciamento dessas formas mais explícitas de violências e da comoção que ela nos provoca tensiona nosso olhar para um posicionamento analítico em relação a esses fenômenos, um olhar capaz de explorar os múltiplos significados contidos nesses atos e que podem não estar assim tão visíveis e explícitos ou mesmo que podem ocorrer em espaços que, via de regra, não são pensados como locus da violência, como o espaço doméstico, o local de trabalho ou instituições como a escola. Por outro lado, também somos provocados a refletir justamente sobre as diferentes percepções acerca da violência: o que é violência para alguns, pode assim não se constituir para outros. Podemos nos opor, de forma muito enfática, a determinadas formas de violência e, ao mesmo tempo, reproduzirmos práticas violentas que assim não se constituem aos nossos olhos. 
Acercar-se da violência não apenas como problema social mas como conceito, como uma questão sociológica constitui, sempre, um grande desafio, tendo em vista tanto a complexidade desses fenômenos quanto a necessidade de um distanciamento, de modo a possibilitar um olhar analítico sobre a questão. Nesse sentido, este texto propõe uma reflexão acerca do conceito de violência e sua relação com as noções de crime e conflito a partir de uma sociologia das conflitualidades, cuja abordagem busca reconstruir tais fenômenos, atentando para suas especificidades. Aprofundar a reflexão acerca do que é violência, conflito e crime constitui um exercício fundamental para complexificar e compreender os diversos processos conflitivos que tomam lugar na escola e na sala de aula, espaços para os quais este texto busca lançar um olhar a partir de uma sociologia das conflitualidades.

\section{VIOLÊNCIAS, CONFLITOS E CRIMES: APROXIMAÇÕES CONCEITUAIS}

Qualquer exercício de compreensão e interpretação dos fenômenos da violência na sociedade contemporânea não pode abdicar de uma postura epistemológica que parta do reconhecimento da complexidade do fenômeno que considere tais processos nas tramas sociais e históricas nas quais eles estão inseridos. Por essa razão, Tavares-dos-Santos (2009, p. 17) propõe a complexidade como uma primeira ideia-elemento para construção do olhar sociológico sobre a conflitualidade social contemporânea.

O caminho sociológico para se compreender a violência social segue a reconstrução da complexidade das relações sociais e de poder, as quais se exercem por múltiplas formas, de um modo transversal a vários eixos de estruturação do social. Tais eixos podem ser dispostos em cinco conjuntos relacionais de conflitualidades: classes sociais, relações étnicas, relações de gênero; processos disciplinares; dispositivos da biopolítica; e os processos mentais inconscientes. 
Em cada conjunto de relações sociais reconhecemos relações de força entre a ordem e a desordem, macro e micro poderes; e tensões sociais, algumas das quais originam conflitos sociais, outras geram lutas sociais, em diversas expressividades. (Tavares-dosSantos, 2009, p. 17)

Ao partir de uma ideia-elemento da complexidade social, Tavares-dosSantos (2009) propõe a reconstrução desses fenômenos e das múltiplas dimensões que os compõem e traça uma diferenciação fundamental de algumas noções que perpassam esse campo temático.

A reconstrução da complexidade desses múltiplos fenômenos constitui um exercício imprescindível para nos aproximar da sua compreensão; isso se torna bastante visível quando, em uma determinada situação em sala de aula, por exemplo, nos deparamos com uma resposta grosseira, um gesto ou ato violento, uma reação agressiva e a consideramos apenas por aquele momento, como se ela representasse a totalidade da vida daquele sujeito. A sociologia das conflitualidades nos provoca a reconstruir a complexidade das tramas sociais que culminam na ação representada à nossa frente, considerando o contexto histórico e social onde essa cena e esse sujeito estão inseridos, de modo a compreender quais os códigos que estão sendo acionados nessa interação.

O reconhecimento dessa complexidade também implica que aprofundemos um pouco mais algumas noções que, vez ou outra, são tratadas como equivalentes: violências, crimes e conflitos. Quando falamos em crime, estamos nos referindo a uma categoria jurídica, ou seja, trata-se de um código, estabelecido na forma de uma lei, que não apenas tipifica um determinado tipo de comportamento como crime, mas também prescreve uma pena, uma sanção àqueles que o praticarem. Cada sociedade ou grupo estabelece para si quais são os comportamentos considerados ofensivos àquela coletividade. Desse modo, numa acepção sociológica, o crime consiste numa ofensa aos sentimentos coletivos de determinada sociedade e não há o crime em si, mas sim as diversas formas pelas quais as diferentes 
sociedades definem quais são essas ofensas (Durkheim, 1978). Essa ideia contribui para compreendermos como há diferentes concepções de crimes e o que é considerado crime em uma determinada sociedade não o é em outra, já que esses sentimentos coletivos variam em diferentes contextos históricos e sociais.

Essa definição do crime é interessante para compreendermos justamente que não há o crime em si, mas diferentes modos pelos quais as diversas sociedades definem quais são as práticas e condutas que ameaçam esses sentimentos coletivos. Por outro lado, pensar nessa noção de crime para as sociedades complexas contemporâneas nos impõe novos olhares, justamente considerando que há uma multiplicidade de sentimentos coletivos - por vezes opostos, contraditórios, que entram em conflito na trama social. Um bom exemplo para provocar a reflexão é pensar nos casos de linchamentos, bastante comuns no cenário brasileiro, quando a própria sociedade legitima atos de violência em nome de determinados sentimentos coletivos e acaba também infringindo a lei, cometendo crimes contra outros indivíduos que supostamente também cometeram algum crime.

A violência, por sua vez, não encontra seu substrato ou fonte de legitimação numa tipificação jurídica. Ela está disseminada no tecido social, tanto através de formas mais visíveis, das marcas físicas deixadas nos corpos, quanto nas suas dimensões veladas e simbólicas. A violência seria a relação social, caracterizada pelo uso real ou virtual da força ou coerção que impede o reconhecimento do outro - pessoa, classe gênero ou raça -, provocando algum tipo de dano, configurando o oposto das possibilidades da sociedade democrática (Tavares-dos-Santos, 2009, p. 16).

A compreensão dos múltiplos fenômenos de violência que atravessam a sociedade contemporânea não pode ser buscada sem uma historicização desses processos sociais. Ao situar o contexto atual, sobretudo a partir do início do século XXI, Tavares-dos-Santos (2009, p. 15) faz referência ao chamado processo de mundialização, que é marcado pela globalização dos processos econômicos e pela mundialização das novas questões sociais mundiais. Dentre essas novas questões sociais que marcam o processo 
de mundialização, destaca-se a violência nas suas mais diversas formas de expressão.

Os fenômenos da violência adquirem novos contornos, passando a disseminar-se por toda sociedade contemporânea: a multiplicidade das formas de violência - violência política, costumeira, violência de gênero, violência sexual, racista, ecológica, simbólica e violência na escola, configuram-se como um processo de dilaceramento da cidadania (Tavares-dos-Santos, 2009, p. 16).

É interessante perceber que o autor não trabalha a partir de um conceito geral de violência - como se fosse um fenômeno único, passível de uma definição universal -, mas sim com uma noção mais complexa de que há "fenômenos da violência" que expressam uma rede de poderes que se sobrepõem, estão continuamente em circularidade e se manifestam nos microprocessos cotidianos da vida social. Portanto, para compreendermos os fenômenos da violência, precisamos buscar compreender como se estabelece essa rede de múltiplos poderes, que sujeitos estão nela envolvidos e mediante quais dinâmicas se dão esses fenômenos.

O autor identifica uma multiplicidade de fenômenos da violência ligados a questões políticas, raciais, sexuais, de gênero, às relações na escola, nas famílias e outras instituições que evidenciam a chamada violência difusa, pois ela está disseminada por todo o tecido social. Essa violência difusa coloca desafios à sociedade contemporânea e às suas instituições que se veem, hoje, diante da necessidade de reconhecer essas formas de violência e pensar estratégias para enfrentá-las.

Nesse sentido, ao correlacionarmos estas primeiras noções - de crime e de violência -, já é possível identificarmos algumas especificidades em relação a cada uma. A noção de crime implica uma tipificação jurídica, precisa estar explicitada em códigos para que possa ser acionada e reconhecida pelos mecanismos da justiça. $\mathrm{O}$ crime não é sinônimo de violência. Há alguns crimes que são executados sem violência, como o furto, quando 
algum pertence da vítima é subtraído sem que ela perceba. Os fenômenos da violência, por sua vez, não são tão fáceis de categorizar; trata-se de processos complexos e multifacetados que envolvem uma multiplicidade de fatores, não podendo ser "encapsulados" numa categoria jurídica.

Essa distinção é interessante e nos possibilita incursionar pela complexidade que envolve cada noção. A temática da violência de gênero nos fornece um exemplo interessante para pensarmos essa distinção. A promulgação da Lei Maria da Penha, em 2006, expressa uma aposta política que os movimentos sociais têm feito na revisão jurídica e nas instituições da justiça criminal como forma de enfrentar a violência contra a mulher, processo que tem sido chamado de judicialização das relações sociais (Debert; Gregori, 2008, p. 165).

Para as autoras, este recurso ao direito penal deixa evidente o que elas denominam de "encapsulamento da violência pela criminalidade" (Debert; Gregori, 2008, p. 165). Isso contribui justamente para evidenciar que essas duas noções expressam processos sociais distintos que precisam ser compreendidos dentro de suas complexidades e das teias de relações que as compõem. Nesse âmbito, o encapsulamento da violência pela noção de crime pode vir a representar a ideia de que apenas a produção de uma categoria jurídica acerca do fenômeno pudesse dar conta do que é a complexidade da violência de gênero. A tipificação jurídica da violência contra a mulher tem uma importância política que não se pode deixar de considerar, pois ela estabelece uma fronteira e sinaliza que isso não é possível, que a violência contra a mulher não é algo natural ou aceitável no âmbito das relações sociais. Entretanto, apenas estabelecer que se trata de um crime e que seu o autor receberá uma punição não é suficiente para dar conta da complexidade do que é a violência de gênero. Seja porque os efeitos (psicológicos, psíquicos, materiais, corporais, subjetivos) dessa violência não são simplesmente "apagados" com a punição do agressor, seja porque apenas o recurso ao direito penal não contribui para tensionar, problematizar ou descontruir os termos pelos quais essa violência se constrói. Dito de outra forma, apenas a tipificação jurídica do fenômeno não garante ou resolve o problema da violência de gênero, que envolve uma multiplicidade de dimensões, tem 
como substrato um conflito de gênero que é histórico e que demanda uma mudança cultural de longa data nas representações acerca dos papéis de gênero.

Assim, para as autoras, é também pertinente essa diferenciação entre o crime e a violência.

Da mesma forma, o significado de violência - que atribui o sentido de danos, abusos e lesões a determinadas ações - é construído historicamente e depende do poder de voz daqueles que participam do jogo democrático. É, portanto, de importância fundamental empreender distinções entre os significados de processos de violência e daqueles processos que criminalizam abusos. (Debert, Gregori, 2008, p. 166).

Outra noção chave que compõe o quadro interpretativo de uma sociologia da conflitualidade, conforme proposta por Tavares-dos-Santos (2009), é a ideia do conflito. O autor retoma a linhagem sociológica da sociologia do conflito, cujo principal argumento não é simplesmente o de que a sociedade consiste em conflito, mas o de que, quando o conflito não é explícito, ocorre um processo de dominação (Collins, 2009, p. 49) ${ }^{1}$. Para os teóricos dessa tradição, a ordem social é constituída por grupos e indivíduos que tentam impor seus próprios interesses sobre os outros, sendo que podem ou não irromper conflitos abertos nessa luta para obter vantagens.

Portanto, partindo dessa abordagem, o conflito não constitui um processo necessariamente desagregador da sociedade, mas inerente às relações sociais e potencialmente criador de outras relações sociais. Da mesma forma, o conflito não implica necessariamente violência, mas pode refletir uma pluralidade de diferentes tipos de normas sociais, padrões de códigos de orientação de conduta que são divergentes e incompatíveis (Tavares-dos-Santos, 2009, p. 19).

1 Randall Collins (2009) apresenta na obra Quatro Tradições Sociológicas as principais tradições do pensamento sociológico clássico e seus desdobramentos no pensamento sociológico contemporâneo. As quatro tradições trabalhadas no texto do conflito, a racional-utilitarista, a durkheiminiana e a microinteracionista. 
Desse modo, seguindo a proposta de uma sociologia das conflitualidades, que instiga a olhar e traçar a complexidade dos fenômenos, propomos agora uma reflexão sobre o espaço escolar, buscando evidenciar de que forma essa diferenciação entre os fenômenos da violência, os conflitos e os crimes nos ajuda a compreender a complexidade das relações que se estabelecem na escola.

\section{POR UMA SOCIOLOGIA DAS CONFLITUALIDADES NA ESCOLA}

A busca por uma compreensão dos processos conflitivos e violentos que se dão no espaço escolar não pode abdicar de uma reflexão mais ampla que situe as mudanças que marcam a sociedade contemporânea. São transformações que manifestam dimensões econômicas, políticas, sociais e culturais, impactando nos padrões de sociabilidade e de interação social. A escola, enquanto uma instituição central no processo de socialização das novas gerações, afeta e também é afetada por essas transformações.

O imaginário social sobre a escola esteve marcado por um bom tempo como um lugar do aprendizado, do conhecimento, da sociabilidade entre alunos e professores e não como um espaço de violências, mesmo considerando que era comum a utilização de castigos físicos como forma de educar; isso não era percebido como violência, mas naturalizado como parte do processo educativo.

O contexto contemporâneo, marcado pela violência difusa e por uma multiplicidade de novas conflitualidades, coloca a escola diante de uma nova configuração de relações sociais e escolares, trazendo-a à tona também como um lugar de produção de violências.

Para Tavares-dos-Santos (2009), a violência no espaço escolar constitui uma nova questão social mundial, considerando-se que o fenômeno começa a ser reconhecido e visibilizado em um conjunto expressivo de sociedades nos últimos 10 anos, com alcance global e não apenas nos países periféricos. 
Em seus estudos sobre o fenômeno na cidade de Porto Alegre (Tavaresdos-Santos, 1999), o autor não identifica algo como uma "violência na escola", mas antes uma multiplicidade de fenômenos que dizem respeito a violências, conflitos e crimes, que expressam dinâmicas, motivações e significados distintos que precisam ser decodificados.

Para o autor, faz-se necessário distinguir as diferentes formas de "violência na escola". Em primeiro lugar, há uma violência que se origina "fora da escola" e que acaba adentrando ou influenciando as relações dentro do espaço escolar. Essa dinâmica violenta possui relação estreita com outras dinâmicas criminais, como o tráfico de drogas.

A outra forma de violência na escola está relacionada às formas de sociabilidades violentas entre os jovens que se produzem no tecido social. Essas formas de violência estão atreladas a uma socialização marcada por códigos violentos que, numa situação de conflito, podem se transformar em atos violentos.

Neste último caso, podemos observar a violência configurandose como linguagem e como norma social para algumas categorias sociais (Tavares-dos-Santos, 2009, p. 19). Nesse ponto de vista, a violência não é percebida necessariamente como um dano, mas como uma forma possível de expressão, de comunicação, ainda que produza danos materiais, subjetivos, simbólicos. A violência como norma social expressa uma internalização de códigos violentos que podem ser manifestados nas mais variadas formas verbais, corporais, gestuais, simbólicas - em que, muitas vezes, o próprio autor de atos violentos não reconhece estar produzindo um dano, mas ao contrário, está manifestando-se, expressando-se de alguma forma. Essas diferenças somente podem ser percebidas e tensionadas considerando como os conflitos e as violências são relacionalmente produzidos, ao ponto de que o que é violência para alguns, para outros é uma forma de manifestação, uma forma de perceber e de estar no mundo. Nesse aspecto, é preciso que se problematize justamente a forma como se constroem os processos de socialização que acabam tornando possível que a violência venha a se configurar como um código social, como uma forma de linguagem. 
E, por fim, o autor destaca a violência que emerge na própria instituição escolar, no intuito de preservar a ordem, de manter o disciplinamento dos alunos. Essa forma de violência pode emergir como forma de resolução de conflitos a partir de divergências de códigos de orientação de conduta.

Talvez fosse mais adequado denominarmos as incivilidades como um conflito de civilidades, pois entre professores e alunos há portadores de diferentes normas de conduta, o que se manifesta por formas menores, moleculares e cotidianas de violência no espaço escolar, indicando a difícil questão da convivência entre grupos sociais que utilizam diversos códigos culturais nas relações de sociabilidade. (Charlot; Emin, 1997 apud Tavares-dos-Santos, 2009).

A maneira como a escola resolve seus conflitos pode, por exemplo, atenuar ou agravar uma determinada situação.

Esse último aspecto é fundamental para a argumentação desenvolvida neste texto: a proposta de uma sociologia das conflitualidades no espaço escolar provoca justamente a construção de um olhar complexo sobre essa realidade que busque reconstruir os conflitos que se dão nesse espaço, traçando as tramas pelas quais os sujeitos são atravessados de modo a compreender quais os significados dos atos de violência, das divergências entre os códigos mobilizados. Para que essa comunicação e compreensão se efetivem no espaço da sala de aula, os professores precisam conhecer seus alunos, conhecer suas realidades, suas identidades, os contextos sociais de suas famílias e comunidades.

A reconstrução da conflitualidade que perpassa esse espaço também é fundamental para que se possam distinguir as situações que estão em jogo e quais os encaminhamentos mais adequados para cada uma. Nem todos os conflitos que tomam lugar na escola levam necessariamente à violência. Por outro lado, um conflito que não é visibilizado e solucionado pode culminar numa situação de violência mais grave ou mesmo num crime. 
É preciso reconhecer que a escola e a sala de aula são espaços de conflitos. Isso não é necessariamente prejudicial às rotinas escolares e ao aprendizado. É fundamental olhar para esse espaço tendo como horizonte não uma sociedade da harmonia ou do consenso, mas ao contrário, a possibilidade de vivermos numa sociedade em que os conflitos sociais possam vir à tona, possam ser socialmente visibilizados, tensionados e solucionados. Ao levarmos em conta que os conflitos fazem parte da realidade social, das relações sociais, estamos dando vazão à complexidade do tecido social e podemos, assim, esperar uma sociedade menos violenta, na qual os conflitos sociais não culminem em atos de violência. Se nosso horizonte for uma sociedade harmônica a consensual, os conflitos - que fazem parte do tecido social - acabam sendo vistos como problemas sociais e não como a expressão da diversidade ou da multiplicidade de códigos culturais e sociais.

\section{CONSIDERAÇÕES FINAIS}

A violência na escola figura hoje como uma das novas questões sociais mundiais (Tavares-dos-Santos, 2009) e precisa ser compreendida nas suas mais variadas formas de expressão. Por outro lado, é preciso reconhecer que a escola é um espaço multicultural, diverso, complexo e marcado por múltiplos conflitos sociais que não implicam necessariamente formas de violência. Os conflitos presentes na escola trazem consigo um potencial de transformação, de criação de novos laços sociais e por essa razão podem ser trabalhados pedagogicamente, por meio de estratégias de mediação que passam por procedimentos de escuta e de fala. A mediação de conflitos é hoje uma prática extremamente necessária no espaço escolar, tanto por possibilitar momentos de fala e de escuta quanto porque implica os sujeitos na resolução dos seus conflitos, empoderando-os para que eles próprios encontrem uma solução para suas divergências. O enfrentamento das violências e a resolução dos conflitos que perpassam o espaço escolar passam necessariamente pelo protagonismo dos sujeitos envolvidos nesse processo, ou seja, a comunidade escolar: professores, alunos, pais, diretores, funcionários e comunidade. 
A sociologia das conflitualidades nos desafia à construção de um olhar complexo sobre a realidade escolar, buscando reconstruir e compreender os significados dos fenômenos da violência e dos conflitos sociais que se manifestam nesse espaço.

\section{REFERÊNCIAS}

COLLINS, Randal. O surgimento das Ciências Sociais. Quatro tradições sociológicas. Petrópolis, Rio de Janeiro: Vozes, 2009.

DEBERT, Guita Grin; GREGORI, Maria Filomena. Violência e gênero: novas propostas, velhos dilemas. Rev. bras. Ci. Soc. [online]. 2008, v. 23, n. 66, p. 165-185.

DURKHEIM, Emile. As regras do método sociológico. São Paulo: Editora Nacional, 1978.

TAVARES-DOS-SANTOS, J. V. A palavra e o gesto emparedados: a violência na escola. Porto Alegre: Secretaria Municipal de Educação, 1999. 176p.

. Violências e Conflitualidades. Porto Alegre: Tomo Editorial, 2009.

ZIZEK, Slavoj. Violência: seis notas à margem. Lisboa: Relógio D’Água Editores, 2009. 


\section{O COTIDIANO ESCOLAR COMO UM AMBIENTE DE CONFLITOS E OS DIREITOS HUMANOS COMO ESTÍMULO À SUA SOLUÇÃO PACÍFICA}

Renan Bulsing dos Santos

Ao analisarmos a história da formação do Brasil, restringindo nosso foco a observarmos como nosso sistema educacional foi construído, é possível concluir que o objetivo inicial das instituições escolares era a alfabetização de uma camada bastante restrita da população: homens, brancos, cristãos, heterossexuais, membros das classes altas. Muita coisa mudou desde então: a Educação é compreendida hoje como um direito humano universal, motivo pelo qual o acesso à escolaridade é um dever de todos os Estados em relação às suas populações. Em especial nas últimas décadas, o Brasil tem feito diversos esforços no sentido de erradicar o analfabetismo, ampliando vagas e estendendo o acesso ao ensino básico e médio. Nesse processo, grupos tradicionalmente excluídos da escola vêm, enfim, tendo acesso a ela.

Em razão disso, os educadores têm-se deparado com mudanças no perfil do alunado: é cada vez mais frequente a presença de estudantes que destoam dos demais em razão de algum marcador social de diferença. Seja em termos de classe social, raça, religião, gênero, sexualidade, ou outras características, o fato é que nunca antes o ambiente escolar no Brasil foi tão 
marcado pela diversidade de identidades dos estudantes. O país apresenta uma configuração multicultural, e essa pluralidade tem sido uma tendência em todo o planeta.

Esse grande conjunto de diferenças entre as pessoas muitas vezes resulta em discordâncias. A divergência é um efeito inevitável da convivência coletiva, e não é em si algo negativo. Não é preciso encará-la como uma ameaça, pois o conflito tem um potencial construtivo: ao me deparar com posicionamentos distintos do meu, posso descobrir caminhos que antes eu sequer cogitava. Ao ver minhas verdades questionadas, posso me permitir fazer novas perguntas, e a partir delas, repensar minhas opiniões. Muitas vezes, apenas quando sou desafiado pelo outro enfim faço o esforço de enxergá-lo e reconhecer suas demandas.

Contudo, Hicks salienta:

Uma consequência destrutiva do conflito é o processo de alienação e o isolamento entre as partes, criando a distância e a falta de comunicação que resultam no processo de desumanização. Informações precisas sobre a outra parte são substituídas por distorções e estereótipos que alimentam e agravam o conflito. O outro deixa de ser importante, o que justifica o impulso para humilhar e aniquilar. (Hicks, 2007, p. 152)

Propomos aqui uma sutil diferença entre as palavras conflito e confronto, mais em termos de grau do que de natureza; o conflito pode resultar em confronto (e, muitas vezes, uma tentativa mal calculada de resolução de conflito pode ser justamente o gatilho de um confronto). O conflito pode se manifestar de modo intenso, porém, conforme ficar mais evidente a dimensão da violência, mais ele se configura em um confronto. A violência pode se manifestar tanto pela via física (danos ao corpo), material (dano 
a objetos), psicológica (provocar medo ou ansiedade) ou moral (espalhar mentiras ou calúnias, constranger o outro publicamente) ${ }^{1}$.

A importância dessa distinção é apenas para que possamos compreender que o conflito (ou, digamos, um confronto numa etapa muito inicial) contém um potencial positivo, que deve ser explorado; não apenas para resolver a situação tensa em específico, como também pode servir para o futuro. Um conflito bem administrado pode servir para modificar comportamentos, tanto dos envolvidos, como de outros atores ao redor deles. Essa é uma perspectiva similar, em muito menor escala, a de uma diplomacia preventiva, proposta pelo ex-secretário-geral da ONU, Boutros Boutros-Ghali, no documento "Uma Agenda Para a Paz" (apud Hicks, 2007, p. 157): "ação para evitar que surjam disputas entre as partes, para evitar que disputas existentes cresçam e se tornem conflitos, e para limitar que o conflito se espalhe."

\section{A MEDIAÇÃO COMO ESTRATÉGIA DE SOLUÇÃO DE CONFLITOS}

A escola é um espaço público, ou seja, é um ambiente em que eu não tenho uma garantia de antemão de que não conviverei com essa pessoa ou aquela. Espaços públicos são ambientes de livre circulação, que somos obrigados a compartilhar, mesmo com pessoas portadoras de características com as quais não estamos acostumados, ou mesmo das quais não gostamos. Sendo o Brasil uma república democrática, comprometida com diversos pactos de direitos humanos assinados diante da comunidade internacional, nós, cidadãos, somos todos comprometidos com uma convivência harmoniosa e pacífica, a despeito de nossas diferenças.

Nesse sentido, afirma Hicks:

O impulso de distanciar-se um do outro e de atacar psicologicamente, pelo abuso verbal, ou fisicamente,

1 Cabe aqui o lembrete de Reardon: "a violência, em todas as suas formas, é uma agressão à dignidade humana" (2007, p. 64). 
com danos corporais, deve ser contido. Atualmente, este impulso teve maus resultados nas instâncias em que a violência pode ser observada em todos os níveis de interação humana: na família, nas escolas, nas comunidades e entre os países. (Hicks, 2007, p. 161)

É importante destacar que não são as diferenças em si que resultam em conflitos, e sim as desigualdades sociais construídas em cima dessas diferenças. Por exemplo: ainda hoje encontramos indicadores estatísticos apontando que as mulheres costumam receber salários menores que os homens (mesmo quando possuem a mesma formação, contratadas para desempenharem as mesmas funções $)^{2}$. Isso não significa que haja qualquer problema em nascer mulher; significa que há um problema cultural ainda não resolvido, presumindo haver uma diferença entre as capacidades laborais de um e de outro.

Houve uma longa e árdua luta dos movimentos de mulheres para conquistarem o direito de serem tratadas com os mesmos direitos que os homens sempre detiveram, e é uma luta que infelizmente ainda não venceu por completo as discriminações das quais as mulheres permanecem sendo vítimas. Pensamento similar pode ser aplicado aos demais marcadores sociais da diferença, que, como dito no início, cada vez mais são expressos e reconhecidos no ambiente escolar. E, espelhando os conflitos relacionados às desigualdades da sociedade como um todo, também na escola eles acontecem.

É bastante comum que os educadores, quando se deparam com situações de conflito na escola, costumem adotar dois comportamentos: ou tentam conter o fato e dispersar os sujeitos o mais rápido possível (objetivando apenas evitar que o evento piore e se alastre), ou se esquivam de resolvê-lo, requisitando a intervenção de terceiros (outros profissionais

\footnotetext{
2 "O salário médio de uma mulher brasileira com educação superior representa apenas $62 \%$ do de um homem com a mesma escolaridade, apontou um relatório divulgado nesta terça-feira, 24, pela Organização para Cooperação do Desenvolvimento Econômico (OCDE), com dados de 46 países. A porcentagem posiciona o Brasil, empatado com o Chile, no primeiro lugar do ranking de maior discrepância de renda entre gêneros no mercado de trabalho." (Fonte:<http://noticias.uol.com.br/ultimas-noticias/agencia-estado/2015/11/24/brasil-tem-maior-diferenca-salarialentre-homens-e-mulheres.htm >, acesso: dez. 2015).
} 
da própria escola, ou profissionais externos, como psicólogos, médicos, policiais, juízes, ou mesmo os pais/responsáveis).

Transferir a responsabilidade é sempre problemático, pois, ao fazê-lo, abre-se margem para críticas: falta de capacidade, comprometimento e/ou interesse do educador e/ou da escola. Fora o fato de que a transmissão de responsabilidade nem sempre significa que o problema será resolvido, muito menos que o será de forma satisfatória - em especial, quando a escola requer que os pais ou familiares resolvam o problema (as famílias resolverão como lhes parecer mais adequado e, como não possuem nenhum treinamento específico, podem fazê-lo de modo ineficaz).

A escola existe para transmitir conhecimentos, mas não apenas em termos do conteúdo técnico das disciplinas. A escola não transmite apenas conhecimento intelectual; também ensina a convivência coletiva. Os educadores que não enxergam como sendo sua essa responsabilidade estão fazendo um trabalho incompleto e contraproducente, pois se esquivar de resolver os conflitos entre os alunos contribui para mantê-los mais displicentes, barulhentos e resistentes ao aprendizado técnico. Procurar resolver os conflitos também é envolver os alunos, participar da vida deles, demonstrar uma preocupação não apenas passageira com eles, reconhecêlos e respeitá-los como indivíduos, e tudo isso reverbera em uma relação mais consistente também no plano da aprendizagem.

\section{A ESCOLA COMO UM ESPAÇO DE CONFLITOS}

Estamos de acordo quanto à importância de uma atuação ativa por parte dos educadores na resolução dos conflitos escolares. Permanece, porém, a dúvida: como fazê-lo? Uma das principais razões que explicam o comportamento esquivo dos educadores em tentar administrativas situações de tensão é a sensação de despreparo: não sabem exatamente que caminho adotar pra lidar com determinados eventos. Algumas vezes, ocorrem situações conflituosas por meio de piadas ou brincadeiras entre os alunos, e alguns professores preferem enxergá-las como se não contivessem nenhum 
conteúdo conflituoso, quando muitas vezes essas piadas são feitas em cima de característica dos envolvidos centrais às suas identidades (ser muito gordo, muito magro, muito baixo, muito míope, muito lento, muito rápido, muito feminino, muito masculina, muito branco, muito escuro, etc.).

Uma estratégia que vem tendo bastante eficácia em resolver conflitos em sala de aula é pela via da mediação ${ }^{3}$. Na mediação, as partes divergentes são chamadas a empreender um verdadeiro diálogo, no qual cada uma terá sua oportunidade de verbalizar seus motivos, ao mesmo tempo em que se disporá a escutar a outra parte. O objetivo aqui é desestabilizar a tensão por meio da fala, permitindo que as partes se expliquem, apresentem sua posição, e ao mesmo tempo possam escutar o outro e visualizar o evento por uma perspectiva diferente, muitas vezes nem cogitada.

\section{ESCUTAR O OUTRO É RECONHECER SUA DIGNIDADE}

Cabe aqui recuperar parte da argumentação dos direitos humanos para justificar o porquê de uma técnica tão simples e aparentemente ineficaz como o diálogo é, na verdade, tão produtiva. Como afirma Spector (2007, p. 279): “Os direitos humanos não são abstrações ou ideais isolados, mas são, no final, aquilo que acordamos uns com os outros no contexto de nossas culturas e de nosso cenário político".

O cerne do debate sobre direitos humanos é o reconhecimento da dignidade universal de todos os seres humanos. Importante destacar o quão extraordinário é pautar-nos pela universalidade da dignidade: ao postularmos uma dignidade universal, estamos reconhecendo que o mero pertencimento à humanidade nos torna dignos, nos confere direitos, nos assegura um tratamento igualitário. Nenhuma característica física, social, histórica ou geográfica é necessária: basta nascer humano. A dignidade universal foi acordada pela ONU apenas na década de 1950. Ao pensarmos

3 Para maiores informações sobre a mediação de conflitos em escolas, o Conselho Nacional do Ministério Público desenvolveu e disponibilizou excelente material voltado aos educadores: < http://www.cnmp.mp.br/portal/images/ stories/Comissoes/CSCCEAP/Di\%C3\%A1logos_e_Media\%C3\%A7\%C3\%A3o_de_Conflitos_nas_Escolas_-_Guia_ Pr\%C3\%A1tico_para_Educadores.pdf $>$. 
no contexto histórico, percebemos uma mudança de paradigma bastante radical em termos de como a humanidade vinha se portando até ali.

No caso do Brasil, o período escravocrata, no qual todo um grupo humano foi destituído por completo de sua dignidade, havia sido encerrado em 1888 (menos de cem anos antes). A origem dos conflitos raciais deve muito a uma oposição à ideia de igualdade universal: um grupo humano, tecnologicamente dominante, postulou uma divisão de todos os demais grupos humanos do mundo em raças - sendo que a sua própria era considerada a única legítima. As demais eram versões inferiorizadas dela, daí a legitimidade de conquistá-las e escravizá-las.

A transição de um momento histórico em que a humanidade era dividida em raças superiores e inferiores para o reconhecimento da igualdade universal não foi sem conflitos, nem se resolveu por completo. Não é à toa que ainda hoje o racismo se faz muito presente no cotidiano. Contudo, o reconhecimento da universalidade da dignidade, inerente a todos os homens e mulheres pelo simples fato de serem humanos, foi uma grande conquista coletiva, que deve ser disseminada e estimulada. Quanto mais defendermos essa ideia, maiores serão as chances de concretizarmos condições de vida mais igualitárias.

Se todos nós humanos compartilhamos uma mesma dignidade, então toda a vida humana tem o mesmo valor, e então todos merecemos o mesmo respeito. Todos merecemos ser reconhecidos como sujeitos dotados de conhecimento e autodeterminação, capazes do pensamento crítico e de definir o próprio caminho. Todos merecemos ter nossa experiência reconhecida e nossa opinião ouvida. Todos merecemos a chance de participar do debate, expressando nosso ponto de vista.

\section{PROMOVENDO UM AMBIENTE DE APRENDIZADO PACÍFICO}

Há um aspecto da instituição escolar que transmite aos alunos uma ideia de desigualdade de legitimidades: a tradicional divisão de tarefas do processo educacional, na qual os alunos estão lá apenas para aprender, os 
professores apenas para ensinar. Nessa perspectiva, o conhecimento segue uma via unilateral, saindo da cabeça dos professores para ser assimilado pelos alunos, que ou são considerados vasos vazios a serem preenchidos, ou vasos recheados com porcaria, cabendo aos professores tirá-la e substituí-la pelo verdadeiro conhecimento.

Como afirma Meintjes:

Tratar os estudantes simplesmente como receptáculos a serem preenchidos com ideias e informações úteis é privá-los de sua consciência crítica e iludi-los, fazendo-os acreditar que o conhecimento é mais um objeto a ser recebido do que um processo contínuo de investigação e reflexão. (Meintjes, 2007, p. 122)

O aprendizado é um processo de trocas, no interior do qual os alunos também aportam conhecimentos. Ocorre um ganho de qualidade na assimilação da novidade quando ela é transmitida a partir do que os estudantes já conhecem. Ainda segundo Meintjes:

O ambiente educacional mais desejável para uma pedagogia que objetive o pleno exercício da cidadania é aquele em que as relações tradicionais entre os estudantes e os educadores, por um lado, e estudantes e conhecimento, por outro lado, são transformadas. [...] qualquer hierarquia de instrução preexistente deve ser substituída por relações de diálogo horizontais. (Meintjes, 2007, p. 136)

A despeito de os educadores estarem operando a partir desse novo paradigma, o senso comum tradicional descrito antes segue muito presente na cabeça dos alunos: muitos chegam à escola numa atitude defensiva, entendendo-se numa posição de inferioridade em relação aos professores, diretores efuncionários da escola. A isso, somam-se as inúmeras desigualdades do mundo "lá fora", que, por óbvio, também se fazem presentes na escola. As diferentes marcas identitárias perpassam todos os sujeitos, e não é possível 
deixá-las nesse mítico "lá fora”. Tudo isso serve para explicar o porquê de serem tão comuns os conflitos no espaço escolar.

Diante disso, cabe aos educadores o papel fundamental de atuarem na promoção de um ambiente de aprendizado pacífico, e os direitos humanos podem ser uma ferramenta muito útil nesse processo. Nesse sentido, Flowers e Shiman afirmam:

Quaisquer que sejam, injustiças e intolerâncias existentes em uma sociedade também estarão presentes em suas escolas. Os professores são fundamentais para mostrar aos estudantes como analisar eventos em suas próprias vidas através de uma "lente dos direitos humanos”. Os estudantes podem ver que linguagem abusiva, que sugere estereótipos, provocadora, intimidadora e outras formas de discriminação tem uma relação direta com os direitos humanos, assim como manifestações sociais de intolerância, tais como sexismo, racismo e homofobia. (Flowers e Shiman, 2007, p. 266)

É inviável em absoluto que os educadores se responsabilizem para intervir em todas as inúmeras desigualdades presentes na escola (motivadoras dos conflitos). No entanto, os educadores precisam estar atentos para intervirem quando essas desigualdades estiverem operando de modo a prejudicar ou impossibilitar que as partes em conflito manifestam seu ponto de vista. Em toda situação conflitiva há um desequilíbrio de comunicação; em regra, alguma das partes (a que detiver maior quantidade de marcadores sociais da diferença) estará em piores condições de se manifestar e ser ouvida (e, portanto, reconhecida como digna). Daí o porquê de a mediação ser um caminho eficaz, ao apostar numa solução na qual todas as partes são colocadas em igualdade em relação umas às outras, conferindo a cada uma a chance de expressarem seus pontos de vista. Cada parte poderá manifestar a razão pela qual está se sentindo agredida em sua dignidade pelo comportamento do outro, sem chance da recusa deste a escutá-la. 
Como afirma Hicks (2007, p. 149), "a resolução dos conflitos exige uma análise das necessidades humanas não atendidas que estão na raiz da luta", e para descobri-las, é preciso empreender o diálogo. O autor oferece uma orientação mais prática sobre como mediar:

[...] o diálogo deveria começar com uma "avaliação de necessidades", e seria seguido por um período de avaliação conjunta, durante o qual os próprios participantes trariam propostas de como lidar com as necessidades expostas por ambas as partes e quais as restrições que cada parte teria. (Hicks, 2007, p. 153)

Ao ter a oportunidade de se manifestar e ser ouvida, a parte agredida vivencia um lugar de legitimidade para expressar a sua experiência de vida. $\mathrm{O}$ ato de ouvir a experiência do outro permite se colocar no lugar dele e reconhecê-lo como alguém que também sofre, e também merece não sofrer. Nesse processo, contar a própria história confere validação e reconhecimento à violência sofrida ${ }^{4}$, e escutar a história do outro permite o desenvolvimento da empatia para com o sofrimento alheio. Estabelecem-se aí as bases para uma conexão emocional, capaz de neutralizar e/ou ressignificar a relação conflituosa.

Hicks salienta:

A hipótese básica de que necessidades humanas não atendidas precisam ser tratadas nas relações de conflito traz implícita outra crença fundamental, a de que as necessidades humanas não são negociáveis. Assim, o processo de resolução de conflitos que lida com o nível de necessidades não pode ser baseado em acordos ou barganhas, que sempre caracterizam técnicas de negociação que tratam dos "interesses" de cada parte. Ao contrário, o processo envolve ado-

4 Segundo Hicks (2007, p. 155): "Este tipo de reconhecimento é um passo significativo no processo de cura dos que se tornaram vítimas, e pode contribuir para a reconstrução de sua autoestima como membro de um grupo com a mesma identidade ao qual são negados os direitos civis.” 
tar uma abordagem "analítica", por meio da qual se cria o ambiente para a "resolução do problema", atacando as raízes do conflito. O propósito é analisar as necessidades de cada parte sem discussões, para ter ideia da perspectiva de cada uma. Nas relações de conflito, as informações que cada parte tem uma da outra são quase sempre baseadas em preconceitos e estereótipos, uma vez que as partes normalmente não tem a oportunidade de conversar diretamente. (Hicks, 2007, p. 151)

Em suma: se os conflitos ocorrem em razão das diferenças que marcam os alunos, mediá-los por meio do diálogo permite reestabelecer uma sensação de igualdade a despeito das diferenças. Não se trata aqui de reduzir as diferenças ou fazê-las sumirem; trata-se de fazer as partes sentirem que, a despeito de serem diferentes, têm ambas o dever e o direito de se tratarem como iguais, conferindo-se mútuo respeito.

\section{REFERÊNCIAS}

FLOWERS, Nancy; SHIMAN, David. A.. “10. Educação de Professores e a Visão de Direitos Humanos”. In: CLAUDE, P. Richard; ANDREOPOULOS, George (orgs.). Educação em Direitos Humanos para o Século XXI. São Paulo: Editora da Universidade de São Paulo: Núcleo de Estudos de Violência, 2007, p. 253-273.

HICKS, Donna. "06. Resolução de Conflitos e Educação em Direitos Humanos: Ampliação da Agenda”. In: CLAUDE, P. Richard; ANDREOPOULOS, George (orgs.). Educação em Direitos Humanos para o Século XXI. São Paulo: Editora da Universidade de São Paulo: Núcleo de Estudos de Violência, 2007, p. 141-163.

MEINTJES, Garth. "05. Educação em Direitos Humanos para o Pleno Exercício da Cidadania: Repercussões na Pedagogia”. In: CLAUDE, P. Richard; ANDREOPOULOS, George (orgs.). Educação em Direitos Humanos para o Século XXI. São Paulo: Editora da Universidade de São Paulo: Núcleo de Estudos de Violência, 2007, p. 119-140.

REARDON, Betty. “02. Direitos Humanos como Educação para a paz”. In: CLAUDE, P. Richard; ANDREOPOULOS, George (orgs.). Educação em Direitos Humanos para o Século XXI. São Paulo: Editora da Universidade de São Paulo: Núcleo de Estudos de Violência, 2007, p. 61-80. 

LOS, George (orgs.). Educação em Direitos Humanos para o Século XXI. São Paulo: Editora da Universidade de São Paulo: Núcleo de Estudos de Violência, 2007, p. 275-299. 


\section{O INCREMENTO DA PRÁTICA DOCENTE A PARTIR DA EXPERIÊNCIA DA TUTORIA PRESENCIAL: PERCURSO DE (RE)SENSIBILIZAÇÃO ATRAVÉS DA TEMÁTICA DOS DIREITOS HUMANOS}

Rúbia Aparecida Cidade Borges

Prezado Professor, sou sobrevivente de um campo de concentração. Meus olhos viram o que nenhum homem deveria ver. Câmaras de gás construídas por engenheiros formados. Crianças envenenadas por médicos diplomados. Recém-nascidos mortos por enfermeiras treinadas. Mulheres e bebês fuzilados e queimados por graduados de colégios e universidades. Assim tenho minhas suspeitas sobre a Educação. Meu pedido é: ajude seus alunos a tornarem-se humanos. Seus esforços nunca deverão produzir monstros treinados ou psicopatas hábeis. Ler, escrever e saber aritmética só são importantes se fizerem nossas crianças mais humanas. (Texto encontrado na parede de Campo de Concentração, após a Segunda Guerra Mundial.) 
Para exercer a tutoria - presencial ou à distância - o profissional precisa possuir, além do domínio do conteúdo (e das ferramentas que viabilizam o acesso a esses conteúdos pelos cursistas), a habilidade de estimular a busca por respostas pelos alunos do curso. É tentador "transmitir” o conhecimento e direcionar as respostas, mas cabe ao tutor exercer um papel de mediação, de facilitador da aprendizagem, sendo alguém que se propõe a trilhar o caminho do conhecimento com os tutorados e não por eles.

Para que a função da tutoria presencial seja efetiva, o profissional que ocupa essa função precisa elaborar sua práxis pedagógica como mediador dos processos de aprendizagem, incentivando e investigando conhecimentos de própria prática e da aprendizagem individual e coletiva. É essa a pessoa que se relaciona diretamente com os alunos, auxiliando-os na compreensão e na aproximação dos assuntos trabalhados, utilizando-se de meios para o ensino e acompanhamento dos conteúdos, inclusive daqueles que dizem respeito às novas tecnologias de informação e comunicação. É quem estabelece a parceria com o(a) cursista na trajetória a ser cumprida. Cabe a mediação pedagógica do tutor ajudar o(a) aluno(a) a construir seu conhecimento por meio da investigação, exploração, pesquisa, trocas com os demais, elaboração e reelaboração dos processos de aprendizagem.

O tutor presencial atua no polo e tem como finalidade fazer a orientação síncrona para os alunos que estudam na modalidade de EaD (Educação à Distância), enfatizando a necessidade de se adquirir autonomia de aprendizagem. A função do tutor presencial, dentre outras, é a de contribuir para o sucesso de um curso por meio da criação de ações articuladas que envolvam aluno-professor-tutor em um sistema de orientação e de trocas em prol de um trabalho que se constrói e reconstrói mediante esquemas didáticos, oportunizando a construção do conhecimento em um caráter multidimensional.

A tutoria presencial no Curso de Extensão em direitos humanos da UFRGS teve, para mim, uma grata especificidade: éramos eles (os cursistas) e eu professores da rede pública de ensino! Por isso, muito mais do que uma 
relação dicotômica ou hierárquica de professor $\mathrm{X}$ alunos, estabelecemos uma parceria baseada na troca de experiência, no diálogo e no entendimento mútuo dos desafios diários da prática docente. Dessa forma, os cursistas nunca me viram como aquela que fiscalizava e cobrava o cumprimento das tarefas ou como o ser que materializava o sistema de controle e avaliação do curso, mas como alguém que, como eles, partilhava das mesmas dificuldades comuns à vida de quem se propõe ser um bom professor: pouco tempo para planejamento e estudo, dificuldades em estabelecer alianças pedagógicas nas escolas, pouca valorização profissional.

Esse exercício de empatia para com os interlocutores é uma das características que identifico como importante na atuação do tutor presencial. Além disso, verifico ser necessário ter uma concepção clara da aprendizagem e dos objetivos do curso, ser organizado(a), ter boa comunicação, domínio do conteúdo e postura que facilite a construção de conhecimento através da reflexão, do intercâmbio de experiências e informações.

Mais do que ter relação direta com os cursistas, auxiliando o manuseio e aproximação dos conteúdos, o tutor presencial precisa administrar situações de conflito, de euforia, desânimos e rotinas, tentando manter o aluno motivado em seus estudos. Ele precisa manter uma atitude positiva, compreensiva e flexível em relação às demandas dos cursistas, que são também adultos e colegas professores.

O que se vislumbra é um papel ativo para o tutor presencial que seja intercambiável com o papel do tutor à distância, com os professores do curso, com os demais membros da coordenação e com os professorescursistas, mas que tenha suas singularidades e, ainda, que esse profissional tenha uma representação social construída pela própria condição concreta do seu trabalho. É necessário reconhecer que a construção da identidade docente (e nesse caso também da identidade do tutor) é um processo sóciohistórico que tem existência não apenas determinada pela experiência e formação do profissional selecionado para essa função.

Em meu caso, minha atuação como tutora foi influenciada pela minha condição de trabalhadora da educação, funcionária pública há alguns anos, 
92 licenciada em uma ciência humana (Geografia). Fosse outra minha trajetória, diferente também seria minha atuação como tutora presencial, apesar de idênticas as funções solicitadas pelas necessidades do curso. Enfim, minha atuação, muito mais do que em aspectos técnicos, esteve embasada naquilo que me constitui como pessoa: meus valores, minha formação, minhas leituras, minha visão de mundo. $\mathrm{Na}$ interação com os cursistas também e principalmente me constituí como tutora presencial. Afinal, a interação é de extrema importância no processo mútuo de aprendizagens, pois estamos juntos e envolvidos num projeto de interesse comum. A relação de afetividade e empatia entre o grupo é um dos fatores que tornou agradável a jornada pelo curso.

\section{COMO A EXPERIÊNCIA DE TUTORIA "RESPINGOU" EM MINHA CONSTITUIÇÃO E PRÁTICA DOCENTE}

Esses "respingos" em minha prática docente advieram especialmente de duas fontes: da interação com a equipe (demais tutores, professores, coordenação) e cursistas e do meu envolvimento com o conteúdo do curso. Essa interação primeiro citada possibilitou repensar algumas práticas e posturas presentes no ambiente escolar e que passam despercebidas em razão da familiaridade gerada pela rotina. Por vezes nos falta um estranhamento para perceber práticas injustas, discriminatórias, segregadoras em nossos discursos e práticas na escola. Através das conversas nos encontros presenciais com os colegas cursistas e nas reuniões com a equipe, essas situações foram grifadas, enfatizadas e geraram certo "policiamento" sobre a minha fala e atuação docente para contribuir para a erradicação dessas violências para com os alunos.

O papel político do professor é um dos eixos principais da sua formação. Além do domínio dos conteúdos e das práticas pedagógicas, cabe a ele ter uma atuação no ambiente escolar afinado com seu discurso e ambos discurso e práxis precisam estar afinados com um projeto de sociedade cada vez mais justa e igualitária. O educador deve defender um projeto de sociedade e 
atuar tendo como orientação esse projeto. Direção e intencionalidade são necessárias para suas ações, tendo em vista a transformação da sociedade rumo a novos caminhos, a novos propósitos. Por isso, deve-se fazer a vigilância constante da nossa prática, daquilo que é transmitido nas entrelinhas da rotina escolar, na escolha dos conteúdos, na seleção daquilo que é dito, de como é dito e daquilo que é silenciado. Das coisas e pessoas que são vistas ou invisíveis no cotidiano da sala de aula.

A rotina e a familiaridade com as situações fazem com que, por vezes, enxerguemos sem ver, sem perceber. Dessa forma, o bullying, o deboche, a segregação e a violência presentes na escola deixam de chocar o professor e passam a ser "normais" e corriqueiros. Muitas vezes o cotidiano da instituição de ensino anestesia os profissionais em relação às violências a que os alunos são submetidos, muitas delas causadas pelos próprios professores e gestores da escola.

E é refletindo sobre esse lugar chamado escola que podemos dialogar sobre as práticas que fazem brotar os contextos de violências, tais como: as avaliações classificatórias; a homogeneização das diferenças, pelas ações disciplinares e normativas; a coação pelo exagero da autoridade; a desvalorização e as péssimas condições do trabalho dos(as) professores(as); a exclusão de educandos(as) pela seleção meritocrática, entre outros, como zonas de manutenção do poder. Tudo isso fortalece os contextos institucionais e públicos, que são geradores de violências. (Zapelini, 2010, p. 106)

Tenho a certeza de que o professor não deve ser visto apenas como um técnico em questões de ensino, mas como pessoa em processo de construir mudanças em sua identidade e no "sentido de si". Assim, a experiência da tutoria agregou elementos à minha identidade que, obviamente, modificaram minha atuação docente, da mesma forma como as minhas vivências como 
94 professora interferiram e agregaram um olhar diferenciado em minha atuação como tutora presencial.

A constituição pessoal e profissional docente decorre de um processo complexo, que é tecido conforme ele se posiciona em relação a múltiplas e, por vezes, contraditórias situações. Para tanto, contribuem diferentes pontos de vista, valores morais, crenças, discursos elaborados por vários interlocutores em variados contextos sociais, nos vários campos científicos, nas legislações, nas experiências sindicais, etc. No caso, a experiência no Curso de Extensão em Direitos Humanos modificou e acrescentou elementos não só pela interação com outros agentes, mas também, como já dito, pelo conteúdo do curso.

A leitura dos textos propostos para as atividades ressaltou o caráter excludente da escola no Brasil durante séculos. A universalização do ensino nas últimas décadas expôs a escola e nós professores a um grupo de alunos que antes era excluído do ambiente formal de ensino: os deficientes, os miseráveis, os não brancos e não cristãos, ou seja, todos os que fogem dos padrões predominantes até então. Esses novos contingentes de estudantes trouxeram à tona, para os ambientes educacionais, a questão da diversidade de grupos e sujeitos que sempre foram excluídos do direito à educação e dos demais direitos. Essa exposição tencionou e modificou as relações no ambiente educativo e trouxe aos professores novos desafios que fogem muito da preocupação somente com os conteúdos. O estudo desses textos trouxe para mim os mesmos questionamentos que aos cursistas: minha atuação docente contribui para uma sociedade mais justa ou para perpetuar o sofrimento e a segregação de um grupo? Estou sendo omissa e negligente em relação a alguma situação de discriminação? Enfim, sou parte do problema ou da solução? 


\section{SOBRE POR QUE A INTERAÇÃO COM A TEMÁTICA DOS DIREITOS HUMANOS "INUNDOU" MINHAS ESCOLHAS CURRICULARES E METODOLÓGICAS}

Sou professora de séries finais do ensino fundamental de Geografia, licenciada nessa disciplina pela Universidade Federal do Rio Grande do Sul. Atuo há quinze anos na rede pública de ensino, primeiro estadual e atualmente pelo município de Porto Alegre. O que trabalhar nas minhas aulas é uma preocupação minha e de todos os professores. A seleção do currículo acontece através das orientações dos Parâmetros Curriculares Nacionais, pelas recomendações da mantenedora e dos Planos de Estudos da escola e também pelos pressupostos teóricos vistos durante minha formação e em leituras posteriores. No entanto, os assuntos tratados em minhas aulas também precisam respeitar minha constituição como docente e as demandas vindas da realidade dos alunos, para que oportunize aprendizagens significativas. O ensino de geografia não precisa ser útil, mas deve ter sentido.

Cotidianamente, vários segmentos da população e inclusive muitos de nossos alunos estão submetidos a uma série de violações de direitos. Trabalhar a temática dos direitos humanos se faz necessário para "desnaturalizar" essas violações, desenvolver uma visão crítica da realidade e levá-los a questionar vários preconceitos e ideias pré-concebidas sobre assuntos que estão sendo discutidos pela sociedade. Frequentemente a mídia apresenta e as redes sociais disseminam ideias discriminatórias e injustas a respeito de negros, mulheres, "menores de idade", imigrantes, gays. Questões como a maioridade penal, política de cotas, linchamentos, emancipação feminina, direitos civis aos homossexuais, vinda de haitianos para o Brasil ou liberdade de credo suscitam opiniões muitas vezes baseadas somente no senso comum, em conceitos preconceituosos resultantes da intolerância e da falta de conhecimento sobre os temas.

A escolha por trabalhar direitos humanos em minhas aulas de Geografia se justifica pela quantidade de violações (muitas vezes justificadas por uma grande parcela da sociedade) a que muitos alunos de escolas públicas de 
96 periferia estão submetidos, mesmo sem se darem conta. Vale enfatizar, no entanto, que ao trabalhar questões referentes à igualdade, liberdade e cidadania, que são de importância social inquestionável, não se pode abrir mão dos pressupostos teóricos, curriculares e metodológicos das diferentes áreas do conhecimento. A Geografia, por suas características, desenvolve habilidades e competências que não podem ser desprezadas no planejamento. É preciso conciliar a discussão das questões sociais com o bom uso da cartografia, com a análise da espacialização de fenômenos, com o estudo da distribuição das desigualdades socioeconômicas no espaço, com a consideração da interferência das questões culturais e religiosas no modo de vida das populações, entre outros temas previstos pela disciplina. Privar o aluno de áreas de vulnerabilidade social daquilo que a Geografia (ou de qualquer oura disciplina) pode acrescentar em seu desenvolvimento é contribuir para a sua permanência em uma situação de carência e desigualdade em relação a outros jovens que terão melhores oportunidades. A escola tem o papel de acolhimento, de desenvolvimento da cidadania e da reflexão social, mas tem como objetivo, sobretudo, a aprendizagem dos alunos. Abrir mão desse papel é contribuir para que se perpetuem condições de desvantagem da maioria da população em relação a uma minoria privilegiada.

Os direitos humanos são fruto da luta pelo reconhecimento da dignidade humana apesar das diferenças que nos constituem. É a legitimação de direitos e garantias pelo simples fato de, apesar de tudo e de qualquer coisa, sermos humanos, nós todos. As profundas desigualdades que marcam nossa sociedade são mais efetivas e implacáveis em áreas populares e pobres, como a comunidade onde está inserida a escola onde eu e os cursistas lecionamos. As contradições presentes nessas localidades indicam a existência de graves violações de direitos em razão da exclusão social, econômica, política e cultural, que promovem a pobreza, as desigualdades, as discriminações, os autoritarismos, enfim, múltiplas violências contra a pessoa humana.

A participação como tutora presencial no Curso de Extensão em Educação em Direitos Humanos motivou-me a abordar essa temática nas minhas aulas. Pesquisamos o contexto em que foi feita a Declaração Universal dos Direitos Humanos; elencamos garantias/violações desses direitos no 
ambiente escolar e na comunidade, utilizamos os Objetivos do Milênio alcançados em várias regiões do globo para determinar os desafios em relação à garantia de alguns direitos em diferentes continentes e mapeamos no mundo as regiões que precisam avançar em relação à superação de variadas desigualdades. Finalmente, através de pesquisas e fotos da comunidade onde está inserida a escola, determinamos os maiores desafios para a garantia dos direitos humanos nessa localidade. Ou seja, conseguimos trabalhar simultaneamente com o global e o local e aproximar a temática da vida dos alunos, trazendo-lhes motivação e sentido.

A opção por trabalhar a temática em Geografia veio da percepção de que, por estarem em uma área de vulnerabilidade social, esses alunos têm seus direitos negligenciados e violados constantemente. Estão em permanente risco de violação de suas integridades físicas, não têm acesso a boa saúde, educação de qualidade, infraestrutura, moradias dignas. Mesmo assim, também são agentes de violações de direitos ao fazerem bullying com colegas, compartilharem em redes sociais postagens racistas, machistas e homofóbicas. Pensar essas questões em aula aproxima a disciplina da vida dos estudantes, melhora a interação entre eles e com os professores e, principalmente, cumpre na escola o papel de incentivar a cidadania, a busca por melhores condições de vida e a criticidade. A vida, ainda que dura, precisa entrar para a escola.

Ensinar a condição humana. Conhecer o humano é, antes de mais nada, situá-lo no universo, e não separá-lo dele. Como vimos, todo o conhecimento deve contextualizar seu objeto, para ser pertinente. "Quem somos" é inseparável de “onde estamos", “de onde viemos", "para onde vamos". Interrogar nossa condição humana implica questionar primeiro nossa posição no mundo (Tonini, 2014, p. 239).

Paulo Freire, no trecho a seguir, destaca a necessidade de uma educação para além dos conteúdos e dos pressupostos curriculares e metodológicos das disciplinas. Assim, articulado com o desenvolvimento das habilidades 
próprias da Geografia, não posso como educadora me abster de tratar de temas que possibilitem a construção (mesmo que utópica) da sociedade igualitária, justa e fraterna que motiva minha prática:

[s]ó somos porque estamos sendo. Estar sendo é a condição, entre nós para ser. Não é possível pensar os seres humanos longe, sequer, da ética, quanto mais fora dela. Estar longe, ou pior, fora da ética, entre nós, mulheres e homens, é uma transgressão. É por isso que transformar a experiência educativa em puro treinamento técnico é amesquinhar o que há de fundamentalmente humano no exercício educativo: o seu caráter formador. Se respeita a natureza do ser humano, o ensino dos conteúdos não pode dar-se alheio à formação moral do educando. Educar é substantivamente formar (2007, n. 33, grifo nosso).

Não é a prática docente em si que é formadora, mas a capacidade de refletir sobre essa prática. Esse entendimento motivou os cursistas a realizarem o curso em questão e me motiva a refletir a partir da experiência da tutoria. Compartilhamos o entendimento de que, enriquecidos pela tensão da convivência e da aprendizagem, nos conhecemos melhor. Só podemos descobrir quem somos olhando para os outros. Só nos entendemos como homens ou mulheres quando vemos ao nosso lado o outro gênero. Só somos brancos ou negros porque, ao nosso lado, há outras etnias. A escola, seus alunos e professores não podem ver o diferente como ameaça ou anomalia. O outro é sempre uma possibilidade de aprendizagem.

\section{AO FINAL: UMA MULHER/ESTUDANTE/PROFESSORA DIFERENTE DAQUELA DO INÍCIO DA JORNADA}

A educação autêntica proposta por Freire (2002) não se faz de A para B ou vice-versa, mas de A com B, de forma horizontal, mediada pelo mundo. Assim, aprendemos eu e os cursistas-professores no convívio e na nossa 
interação, bem como através dos textos e propostas do curso em si. E, se o desafio em EaD é oportunizar a educação em detrimento da distância, encurtá-la e ampliar ideias, é esse o sentido da transformação pensada pela educação libertadora na concepção de Freire. É possível construir conhecimentos sólidos, com sentido, pelas vias da interação, em ambientes virtuais de aprendizagem, se a ação do tutor, marcada pelo caminho da comunicação dialógica, se estabelecer pelo diálogo verdadeiro entre as pessoas. O tutor presencial pode ser esse link entre professores, alunos e conteúdo.

O crescimento e a aprendizagem se dão no diálogo de homens e mulheres comprometidos com a transformação das coisas em prol da melhoria da vida humana, na capacidade de criar e recriar. Acreditar nas pessoas, nos alunos, na capacidade inerente a todos de melhorar é fundamental para uma Educação em Diretos Humanos. A educação, seja a que distância for, pode isso, porque é fruto da intencionalidade e da ação humana. Como ensina Freire (2002, p. 68), "ninguém educa ninguém, ninguém educa a si mesmo, os homens se educam entre si, mediatizados pelo mundo”.

Somos em um só tempo parte e totalidade. Trazemos dentro de nós - alunos e professores - todas as contradições da sociedade. Somos professores constituídos pela nossa interação, nossas crenças, ideologias, vivências, leituras e personalidades. Cada oportunidade de convívio, de exposição a novas experiências, agrega em nós componentes distintos que aprimoram nossa prática docente. Assim como acredito ter contribuído com o crescimento dos cursistas, tenho plena percepção do que se agregou em mim a partir de tudo o que vivenciei nesse período como tutora presencial do Curso de Extensão em Direitos Humanos.

Trata-se de significações culturais constituidoras da gramaticalidade social que permeia e torna possível a vida em sociedade. É esse repertório de experiências, de saberes, que orienta o modo como o professor pensa, age, relaciona-se consigo mesmo, com as pessoas, com o mundo, e vive sua profissão. Enten- 
demos, pois, que o professor traz para sua prática profissional toda a bagagem social, sempre dinâmica, complexa e única. (Cavalcanti, 2012, p. 22)

Tratar de direitos humanos implica uma postura de compreensão e tolerância para com a diferença, mas de intolerância a quem discrimina o diferente. Não é possível ter os direitos humanos no discurso desarticulado da prática.

Ensinar e, enquanto ensino, testemunhar aos alunos o quanto me é fundamental respeitá-los e respeitarme são tarefas que jamais dicotomizei. Nunca me foi possível separar em dois momentos o ensino dos conteúdos da formação ética dos educandos. A prática docente que não há sem a discente é uma prática inteira. $\mathrm{O}$ ensino dos conteúdos implica o testemunho ético do professor. A boniteza da prática docente se compõe do anseio vivo de competência do docente e dos discentes e de seu sonho ético. Não há nesta boniteza lugar para a negação da decência, nem de forma grosseira nem farisaica. Não há lugar para puritanismo. Só há lugar para pureza (Freire, 2007, p. 95).

Ao final da Segunda Guerra Mundial foi encontrada, em um campo de concentração, escrita em uma parede, a epígrafe que abre esse texto. Destaca a importância de, além dos conteúdos, privilegiar aquilo que nos faz humanos: a solidariedade e a capacidade de nos colocarmos na pele do nosso semelhante. Tantos anos depois e ainda vemos desigualdades e violações de direitos humanos na escola, local do cuidado e do bom senso por excelência. Gostaria de finalizar minha contribuição com outro escrito, desta vez de Bertolt Brecht, amplamente disseminado nas redes sociais. Ele enfatiza essa necessidade da empatia entre os seres e o compromisso de todos, principalmente de nós educadores, em zelar pela dignidade e justiça através da defesa dos direitos humanos: 
Primeiro levaram os negros

Mas não me importei com isso

Eu não era negro

Em seguida levaram alguns operários

Mas não me importei com isso

Eu também não era operário

Depois prenderam os miseráveis

Mas não me importei com isso

Porque eu não sou miserável

Depois agarraram uns desempregados

Mas como tenho meu emprego

Também não me importei

Agora estão me levando

Mas já é tarde.

Como eu não me importei com ninguém

Ninguém se importa comigo. 
CAVALCANTI, Lana. O ensino de geografia na escola. Campinas: Papirus, 2012.

CRUZ, Sônia; INFORSATO, Edson; STEFANINI, Maria Cristina. Formação de professores à luz de Meirieu: interação reflexiva sobre a prática educativa. Revista Brasileira de Política e Administração da Educação. Porto Alegre, v. 25, n. 2. 2009. Disponível em: < http://seer.ufrgs.br/rbpae/ article/view/37410>. Acesso em: 29 set. 2015.

COSTA, Maria Luiza. As representações sociais do trabalho do tutor presencial: limites e possibilidades. Educar em Revista. Curitiba: n. 4. 2014. Disponível em: < http://ojs.c3sl.ufpr.br/ojs/ index.php/educar/article/view/38660>. Acesso em: 29 set. 2015.

FREIRE, Paulo. Pedagogia da Autonomia. São Paulo: Paz e Terra, 2007

Pedagogia do Oprimido. São Paulo: Paz e Terra, 2002.

PERRENOUD, Philippe. Utilizar novas tecnologias. Dez novas competências para ensinar. Porto Alegre: Artmed, 2000, p. 125-140.

TONINI, Ivaine et al. O ensino de geografia e suas composições curriculares. Porto Alegre: Mediação, 2014.

ZAPELINI, Cristiane. Violências, Rede de Proteção e Sistema de Garantia de Direitos. Florianópolis: NUVIC-CED-UFSC, 2010. 


\section{GÊNERO NA ESCOLA E DEMOCRACIA À BRASILEIRA: LIMITES E DESAFIOS PARA UMA VIDA LIVRE DE DISCRIMINAÇÃO E VIOLÊNCIA}

Fabiane Simioni

\section{INTRODUÇÃO}

A partir da experiência como professora-formadora em um curso de aperfeiçoamento de Educação em Direitos Humanos para educadoras e educadores de quatro municípios do Rio Grande do Sul, realizado pela Faculdade de Educação da Universidade Federal do Rio Grande do Sul, trago algumas ponderações sobre o debate de gênero no espaço escolar.

Esse curso atingiu sessenta e quatro professoras e professores, durante seis meses do ano de 2015 (março a setembro), com atividades presenciais e à distância. Nesse período, acompanhei as discussões em fóruns virtuais, as produções e as análises sobre os temas de cada um dos módulos que compunham o curso: da historicidade dos direitos humanos, passando pela introdução teórica dos marcadores sociais de diferenças (gênero, raça/etnia, orientação sexual, geração, deficiências físicas e intelectuais, pertencimento regional e religioso) ao papel da escola na mediação e solução de conflitos. 
Neste artigo, apresento algumas reflexões sobre as implicações trazidas pelos retrocessos legislativos decorrentes da retirada do termo "gênero" do Plano Nacional de Educação, seguido dos estaduais e municipais.

O Plano Nacional de Educação (PNE - 2014/2024) é o dispositivo normativo que estabelece metas e estratégias desde a educação infantil até o ensino superior e a pós-graduação, incluindo a formação e a valorização das educadoras e educadores e o financiamento da educação, que deverá atingir, no mínimo, 10\% do Produto Interno Bruto (PIB) até o fim de vigência dessa lei. Após a aprovação do plano nacional, estados e municípios tiveram até o dia 24 de junho de 2015 para aprovar os seus respectivos planos, sendo que nem todos o fizeram ${ }^{1}$.

Foi nesse contexto de mobilização parlamentar e da opinião pública para aprovação dos planos nacional, estaduais e municipais que vimos um intenso debate sobre a (im)pertinência das diferenças sociais e culturais que são trazidas para dentro do ambiente escolar por estudantes, educadoras e educadores, funcionárias e funcionários, pais e mães. De acordo com Anna Paula Vencato (2014, p. 20), há uma série de singularidades trazidas de fora para dentro da escola junto com diferentes pessoas que por ali circulam; mas estas, em geral, são tidas como exóticas e/ou inapropriadas ao contexto escolar e, portanto, como algo que não pode pertencer àquele espaço. A escola, o sistema de ensino e todas as pessoas que fazem parte dele têm historicamente dificuldades em lidar com a questão das diferenças. Essa dificuldade é reflexo da sociedade a que pertencemos e de sua lógica cultural hierarquizada e excludente.

Os efeitos dessa lógica cultural excludente também perpassaram o debate no parlamento e nas tribunas, em que profissionais da educação, comunidade escolar e leigos tiveram oportunidade de opinar sobre o tema. Observamos o apego, a defesa de ideias essencialistas sobre o que é ser mulher ou ser homem e a reivindicação da liberdade de expressão como argumentos para a exclusão de quaisquer referências ao termo "gênero"

1 O Ministério da Educação tem um portal virtual em que é possível acompanhar o mapa de estados e municípios que já aprovaram seus respectivos planos e aqueles que ainda não o fizeram. Ver: < http://pne.mec.gov.br/planos-de-educacao/situacao-dos-planos-de-educacao > . Acesso em: 25 jan. 2016. 
das diretrizes político-pedagógicas da educação brasileira, mais de 45 anos depois de pesquisadoras e pesquisadores das ciências sociais começarem a problematizar as relações de gênero no Brasil ${ }^{2}$, mais de 27 anos de um regime democrático de Estado ${ }^{3}$.

Importante registrar que esse discurso de naturalização das condições de socialização dos gêneros não é novidade no contexto brasileiro recente. No segundo turno para as eleições presidenciais em 2010 vimos grupos religiosos (católicos e evangélicos) ameaçarem a retirada de apoio à candidata Dilma Roussef, caso ela manifestasse uma posição favorável ou tomasse qualquer iniciativa legislativa sobre a descriminalização do aborto, o que se repetiu na campanha de reeleição em 2014 . Em maio de 2011, depois que fora produzidos, sob demanda do Ministério da Educação, materiais audiovisuais para subsidiar o combate à homofobia nas escolas, a presidenta Dilma Roussef vetou a distribuição do referido material (kit anti-homofobia), pressionada pelas bancadas religiosas da base aliada de seu governo.

Os exemplos acima citados são sintomáticos de um discurso que pretende "privatizar" os temas relativos à sexualidade e ao gênero no sentido de retirar desse cenário qualquer interveniência do Estado.

Dessa forma, meu objetivo é demonstrar que a discussão dos temas relacionados à pedagogia dos gêneros no contexto escolar deve estar em acordo com os preceitos normativos constitucionais e de direito internacional dos direitos humanos e, portanto, o Estado tem um papel a cumprir quando se trata de dar efetividade ao direito a uma vida livre de violência e discriminação.

2 Ver CORRÊA, Mariza. Do feminismo aos estudos de gênero no Brasil: um exemplo pessoal. Cadernos Pagu, n. 16, 2001, p. 13-30.

3 A partir da promulgação da Constituição Federal de 1988, o Estado brasileiro se auto reconhece como um Estado Democrático de Direito.

4 Ver BRUM, Eliane. O aborto na fogueira eleitoral. Disponível em: <www.brasil.elpais.com/m/brasil/2014/04/28/opinion/1398692471_063651.html >. Acesso em: 25 jan. 2016. 
Os impactos sociais e culturais posteriores à aprovação do Plano Nacional de Educação (PNE - 2014/2024) ainda estão em processo de elaboração e reflexão. De outra forma, os impactos políticos nos planos estaduais e municipais já podem ser quantificados. Até o momento da escrita deste texto, ao menos oito estados brasileiros eliminaram referências à discussão de gênero: Pernambuco, Paraíba, Tocantins, Acre, Distrito Federal, Espírito Santo, Paraná e Rio Grande do Sul. Aprovaram os respectivos planos e mantiveram o termo gênero: Mato Grosso do Sul, Mato Grosso, Maranhão e Amapá. Estados como São Paulo, Rio de Janeiro, Minas Gerais, Bahia e Ceará ainda não aprovaram seus planos estaduais ${ }^{5}$.

Em alguns municípios, a mobilização da sociedade civil e dos movimentos sociais alcançou a maioria dos membros das Câmaras de Vereadores no sentido de manter o registro do termo gênero no plano de educação, embora a tendência seja de acompanhar o silêncio do Plano Nacional de Educação. Como qualquer debate democrático, cada uma das partes interessadas deveria ter a oportunidade e a representatividade para argumentar sobre o seu ponto de vista. Sabemos que, em localidades onde há pouca organização da sociedade civil, a discussão é muito menos democrática e participativa e, portanto, as decisões políticas são tomadas com base no pressuposto da legitimidade da representatividade do sistema eleitoral $^{6}$. Essa ausência de organização social impacta na exigibilidade de políticas públicas e no monitoramento daquelas já implementadas. Mas não basta ter voz, é preciso que o parlamento também tenha espírito democrático e zelo pelos valores, princípios e normas constitucionais e internacionais

\footnotetext{
5 Ver: <http://www1.folha.uol.com.br/educacao/2015/06/1647528-por-pressao-planos-de-educacao-de-8-estadosexcluem-ideologia-de-genero.shtml>. Acesso em: 25 jan. 2016.

6 Representatividade eleitoral e representatividade social são coisas distintas. Os movimentos de mulheres negras, por exemplo, há tempos insistem que há muita diversidade de experiências entre as mulheres e é preciso reconhecer que há diferenças e implicações importantes entre ser uma mulher negra e uma mulher branca. Nesse sentido, o sistema eleitoral brasileiro está longe de acolher a diversidade de grupos e interesses daqueles apontados como vulneráveis ou minorias: mulheres, negros, indígenas, deficientes intelectuais ou físicos, homossexuais, entre outros. No contexto atual, a chamada bancada BBB (Boi, Bíblia e Bala) representa um esforço de oposição e de resistência às transformações sociais e culturais pelas quais o país vem passando no período recente.
} 
para rever posições, quando for o caso, diante dos argumentos vindos da tribuna e/ou do plenário.

Onde o conservadorismo atuou sem uma oposição igualmente potente, os vetos dos respectivos parlamentos se direcionaram às metas de combate à discriminação racial, de orientação sexual ou de identidade de gênero, pesquisas sobre a permanência de transexuais ou transgêneros na escola, bem como sobre programas de formação continuada para professoras e professores em gênero, diversidade e orientação sexual.

Os membros desses parlamentos, alinhados a diferentes partidos políticos, mas aglutinados em torno de crenças religiosas dogmáticas, consideraram que esses temas representam um problema para a "família tradicional brasileira", porque subverteriam os conceitos de mulher e de homem, de matrimônio e de maternidade.

Prevaleceu a ideia de que discutir sobre esses temas no cotidiano escolar é perigoso e, possivelmente, contaminador para crianças, jovens e adultos, apoiada no equivocado pressuposto de que determinados aspectos relativos às identidades de sujeitos em formação não devem ser explorados dentro do universo escolar, cabendo somente às famílias oferecer a correta orientação quanto aos aspectos relacionados à pedagogia do gênero.

Para além de ser contra ou favor, o que é um equívoco maniqueísta, é preciso compreender o que está em disputa quando se fala em gênero, pedagogias do gênero, relações de gênero, entre outras expressões: gênero é um conceito que permeia e organiza a vida de todo mundo; é tão presente que naturalizamos seus efeitos (Pelúcio, 2014, p. 97).

Segundo Débora Diniz (2014, p. 11-12), gênero é um regime político, cuja instituição fundamental é a família reprodutora e cuidadora, e o patriarcado, uma tecnologia moral. A autora reconhece que existe uma variedade de críticas à ideia de patriarcado, da mesma forma que não seria possível afirmar sua universalidade ou existência desde sempre. Entretanto, reivindica a precedência do patriarcado para a compreensão daquilo que denomina pedagogias do gênero: "As pedagogias do gênero garantem a reprodução do poder patriarcal. As instituições o oficializam como regra de 
governo. As leis são o registro de sua legalidade e de sua potência para o uso da força perante as insubordinadas" (Diniz, 2014, p. 12).

É somente aparente a simplicidade com que a autora enquadra o conceito de gênero. Mas vale a pena o esforço de compreendê-lo. De início, poder patriarcal é aquele que organiza um sistema jurídico-político no qual a autoridade e os direitos sobre os bens e as pessoas obedeciam a uma regra de filiação patrilinear, tendo como titular e representante exclusivo o homem (o pai, o senhor de escravos, o marido - o pater). A reação ao patriarcado seria o seu duplo oposto, o matriarcado. De acordo com Roudinesco (2003, p. 35), no final do século XIX julgava-se necessário reorganizar a soberania patriarcal, uma vez que estava ameaçada por uma "feminilização do corpo social" em que o pai deixava de ser o único vetor de transmissão dos bens culturais e a mulher-mãe, por sua vez, passava a concorrer por um espaço nessa disputa intrafamiliar. Dessa forma, as teses desenvolvidas em torno do matriarcado e do patriarcado se prestariam a densificar o "medo do transbordamento feminino", ou seja, para reafirmar a dominação masculina sobre a feminina como única regra a partir da qual era possível construir as relações entre os sexos (Roudinesco, 2003, p. 36).

Assim, ensinar a pedagogia dos gêneros a partir do poder patriarcal é reforçar a essencialidade do poder de dominação masculino e da subjugação feminina, mas esse reforço à essencialidade das diferenças e hierarquias entre mulheres e homens se ensina e se concretiza a partir das convenções sociais e culturais construídas pelas instituições pedagogizantes (família, escola, igrejas, etc.) e dos modos pelos quais essas convenções governam nossas representações (aquilo que pensamos/elaboramos/descrevemos sobre alguma coisa) e práticas (como nos comportamos). Essas instituições pautam suas normatizações pelos valores hegemônicos do seu tempo e lugar, cuja desobediência ou inconformidade pode ser solvida através do uso (pragmático e simbólico) da força perante aquelas e aqueles que experimentam outras formas de vivências dos gêneros.

Gênero, portanto, é um conceito que afirma o caráter social e plural do feminino e do masculino em termos de tempo, espaço e de diversidade dos grupos sociais (étnicos, religiosos, raciais, de classe). Tem a intenção de 
se afastar de proposições essencialistas ao dirigir-se em uma perspectiva de processo em construção, e não algo que exista (ou sempre existiu) a priori (Louro, 1997, p. 23).

Nesse sentido, as instituições pedagogizantes, entre as quais a família, têm um papel e um dever importante: promover uma vida livre de discriminação e violência para cada um de seus membros. Não é demais repisar que todo o esforço de trazer para dentro da escola o debate de gênero foi e tem permanecido ativo porque as alunas e os alunos estão imersos em relações familiares permeadas por processos de exclusão e violência, sobretudo para aquelas e aqueles que não atendem às expectativas em relação ao seu gênero. Nessas situações, foi a escola que, de alguma forma, passou a prestar atenção nessa aparente invisibilidade. Suspeito que as tentativas de abandono dos estereótipos de gênero na escola tenham se realizado porque o assédio, em geral, e a homofobia, em especial, tivessem se transformado em algo escancaradamente insuportável, elevando cada vez mais os níveis de evasão "involuntária" de estudantes e de professoras. Afirmar que a família, e não a escola, deve ser a única responsável pela pedagogia do gênero, é sugerir que estamos tratando de assuntos pessoais, individuais. $\mathrm{O}$ que estamos postulando é que sexo e gênero são, antes, questões de Estado e, portanto, públicas, não de foro privado; são questões políticas (Pelúcio, 2014, p. 114).

Conforme Cook e Cusack (2009, p. 42), quando um Estado aplica, executa ou perpetua um estereótipo de gênero em suas leis, políticas públicas ou práticas, o institucionaliza dando-lhe a força e a autoridade do direito e do precedente e, portanto, gera uma atmosfera de legitimidade e normalidade. Quando um Estado não adota medidas legais para eliminar e remediar a perpetuação de um estereótipo de gênero por outros meios, tais como os meios de comunicação, as escolas e os currículos, um estereótipo de gênero também é institucionalizado e se lhe outorga a força e autoridade da lei. Quando um Estado legitima assim um estereótipo de gênero, ele estabelece um marco que facilita a perpetuação e discriminação no tempo e através de diferentes setores da vida e da experiência social. 
A ideia de que a família, e não a escola, deva tratar desse assunto é equivocada porque está sustentada em uma falsa dicotomia entre o mundo público, personificado na escola, e o doméstico, na família. Alguns autores identificam, a partir do Estado de Bem-Estar Social (Welfare State) do século XX, uma tendência de redução do espaço da autonomia privada para a garantia da tutela jurídica daqueles considerados mais vulneráveis, implicando uma certa intervenção dos poderes do Estado em setores da vida privada, antes interditados à ação pública, notadamente em Estados liberais (Lôbo, 1999; Carbonnier, 2001).

$\mathrm{Na}$ legislação brasileira, temos vários exemplos dessa tutela jurídica e da opção pela interferência do Estado quando aprovamos leis que pró́bem e punem ações consideradas "privadas" sobre os corpos de mulheres, crianças, idosos ou deficientes para protegê-las da violência doméstica - Lei Maria da Penha, Estatuto da Criança e do Adolescente, Estatuto do Idoso, Estatuto dos Deficientes.

As diferenças entre o público e o doméstico subsistem; porém elas são meramente "quantitativas", pois há situações em que prevalecem os interesses individuais, embora também estejam presentes interesses da coletividade, e outras em que predominam os interesses da sociedade, ainda que funcionalizados à realização dos interesses existenciais das pessoas (Facchini Neto, 2003).

Muito frequentemente, os termos "público" e "privado" são usados com pouca preocupação em relação a sua clareza e sem uma definição precisa, como se todos soubessem o que querem dizer, independentemente do contexto. Há, no entanto, como os estudos feministas têm tornado cada vez mais explícito, ao menos duas ambiguidades envolvidas na maioria das discussões sobre o público e o privado. Público/privado é usado tanto para referir-se à distinção entre Estado e sociedade (como em propriedade pública e privada) quanto para referir-se à distinção entre vida não-doméstica e vida doméstica. Nessas duas dicotomias, o Estado é (paradigmaticamente) público 
e a família, a vida íntima e doméstica são (também paradigmaticamente) privadas.

Para Susan Okin (2008, p. 307-308), a dicotomia público/doméstico é produzida como esferas separadas, de modo a invisibilizar as formas de dependência econômica e as estruturas de poder inerentes na família e na divisão sexual do trabalho produtivo e reprodutivo. A vida familiar é pressuposta ao invés de discutida e a divisão do trabalho entre os sexos não é considerada uma questão de justiça social (Okin, 2008, p. 309-310).

A reprodução dessa dicotomia torna possível a invisibilidade da natureza política da vivência familiar, a relevância da justiça na vida pessoal e, consequentemente, de uma parte central das desigualdades entre mulheres e homens, entre jovens, adultos e idosos. De acordo com a autora, no centro dessa discussão está a análise crítica dos desdobramentos da divisão sexual do trabalho doméstico para a participação das mulheres em outras esferas da vida. A crítica feminista, a partir da politização daquilo que era tido como restrito à privacidade do doméstico, estabeleceu conexões entre a subordinação das mulheres aos homens e a definição dos papéis de umas e outros nas diferentes esferas sociais (Okin, 2008, p. 307).

Mulheres devem exercer sua afetividade (natural e intrínseca, se supõe) no âmbito doméstico e os homens, por sua vez, devem promover a sustentabilidade material, financeira, a partir de sua inserção na esfera não-doméstica. Desde seus primórdios teóricos, toda a divisão sexual do trabalho é fundamental para a dicotomia e a separação entre as esferas públicas e privadas. Os homens são vistos, sobretudo, como ligados às ocupações da esfera da vida econômica e política e responsáveis por elas, enquanto as mulheres seriam responsáveis pelas ocupações da esfera privada da domesticidade e reprodução. As mulheres têm sido vistas como "naturalmente" inadequadas à esfera pública, dependentes dos homens e subordinadas à família. Esses pressupostos, como se poderia esperar, têm efeitos de grande alcance na estruturação da dicotomia e de cada uma das esferas que a compõem. 
Como os estudos feministas descreveram, tanto os direitos políticos quanto os direitos pertencentes à concepção moderna liberal de privacidade $\mathrm{e}$ do privado têm sido defendidos desde os princípios do liberalismo no século XVII como direitos dos indivíduos; mas esses indivíduos foram supostos e com frequência explicitamente definidos como adultos, chefes de família, do sexo masculino. Assim, os direitos desses indivíduos a serem livres de intrusão por parte do Estado, da igreja ou da vigilância curiosa de vizinhos, eram também os direitos desses indivíduos a não sofrer interferência no controle que exerciam sobre os outros membros da sua esfera de vida privada - aqueles que, seja pela idade, sexo ou condição de servidão, eram vistos como legitimamente controlados por eles e tendo sua existência limitada à sua esfera de privacidade. Não há qualquer noção de que esses membros subordinados das famílias devessem ter seus próprios direitos à privacidade (Okin, 2008, p. 307-308).

Quando as escolas foram interpeladas por seus próprios estudantes com situações de negligência, violência, assédio e abuso, na maior parte das vezes promovidos por aqueles que tinham o dever legal de proteger crianças e adolescentes, se viram sem ferramentas para acolher, proteger e tampouco prevenir todo o tipo de discriminação e violência contra mulheres e meninas, contra lésbicas, gays, bissexuais, transexuais e transgêneros. $\mathrm{O}$ que faz uma educadora ou educador quando sua aluna ou aluno relata em detalhes um estupro praticado pelo pai ou outro familiar contra si, sua irmã ou mãe? O que deveria fazer quando no meio de uma aula explode uma confusão causada pela proximidade física entre dois meninos ou duas meninas no fundo da sala de aula? Qual banheiro deve usar o aluno que na lista de presença é identificado por um nome masculino, mas que solicita que seja tratado como uma garota ${ }^{7}$ É possível à escola ignorar a pluralidade de estilos de vida ou de cosmovisões de mundo presente nas sociedades contemporâneas ou no interior das próprias famílias de origem dos estudantes?

\footnotetext{
7 Compartilho da posição de Larissa Pelúcio (2014, p. 118), para quem "nossa pedagogia de gênero insiste que banheiros precisam ser separados porque ensinamos às meninas que meninos são perigosos e elas são presas fáceis; $\mathrm{e}$ ensinamos aos meninos que eles devem ser perigosos e ousados sexualmente. Portanto, a discussão sobre banheiros não é sobre banheiros para homo ou heterossexuais, mas sobre como ocupamos os espaços públicos a partir de um lugar de gênero".
} 
Se essas situações não foram adequadamente acolhidas e mediadas no âmbito doméstico, é na escola, diante de educadoras e educadores e dos demais colegas, enquanto alguns daqueles estudantes ainda permanecem por lá, que são explicitados os pedidos de ajuda e reivindicado o reconhecimento e a escuta dessas demandas.

A teoria liberal tomou o "privado" como a esfera da vida social nas quais a intrusão ou interferência em relação à liberdade requer justificativa especial, e o "público" como uma esfera geralmente ou justificadamente mais acessível e, portanto, com maior tolerância à incidência ou influência externas (Okin, 2008, p. 306). Quando a escola, um espaço de características públicas, em que a autonomia privada é relativizada em função do convívio entre múltiplos e divergentes interesses, é constrangida a fazer de conta que as pedagogias do gênero não adentram nos seus portões, é porque a sociedade, através de seus agentes políticos, optou por "privatizar" aquele espaço, no sentido de torná-lo intolerante quanto à diversidade e às violações de direitos ocorridas dentro e fora do seu ambiente.

Dito de outro modo, a vingar a intervenção do Estado nas escolas para banir o debate de gênero, estaremos, no limite, legitimando a discriminação e a violência contra meninas, mulheres, lésbicas, gays, transexuais e transgêneros em flagrante negação da força normativa da ordem constitucional brasileira, notadamente naquilo que aponta para a centralidade da dignidade humana e a garantia de direitos fundamentais, especialmente de grupos em situação de vulnerabilidade social.

\section{ESTADO DEMOCRÁTICO DE DIREITO}

A Constituição Federal de 1988, fundante do Estado Democrático de Direito, veicula consensos mínimos, essenciais para a dignidade das pessoas e para o funcionamento do regime democrático e que não deveriam ser afetados por maiorias políticas ocasionais. Uma constituição em um Estado Democrático de Direito tem duas grandes funções: (i) proteger valores fundamentais básicos contra a ação predatória das maiorias e (ii) garantir o 
funcionamento adequado da democracia e do pluralismo político (Barroso, 2014, p. 232-233).

A ação predatória da maioria no sistema eleitoral revelou, no debate dos planos de educação, uma reação a algumas conquistas jurídicas e sociais em termos de representatividade e de garantia de direitos para segmentos historicamente invisibilizados em uma sociedade hierárquica e desigual como a brasileira. É como se houvesse uma disputa para a retomada daquilo que se convencionou como tradicional e foi construído como hegemônico para conter "o outro", aquele considerado desviante, subversivo, impuro ou abjeto.

Entretanto, essa nova cruzada contra corpos/sujeitos específicos (porque nem todos são dotados dos mesmos privilégios no acesso aos modos de distribuição de bens, recursos e prestígio) revela uma faceta antidemocrática que acabou por acalentar as mentes e os corações mais conservadores daqueles que não compartilhavam os mesmos compromissos políticos com quaisquer práticas religiosas. Nesse caso, a democracia, como valor e como bem público, é atacada, porque a regra do igual respeito e igual consideração é deturpada para dar lugar a reminiscências de um projeto de heteronormatividade compulsória.

A abordagem das relações de gênero no contexto escolar, entretanto, está inscrita em um marco de combate a todas as formas de violência e de discriminação, como também em normas nacionais e internacionais ratificadas pelo Estado brasileiro. De acordo com a Constituição Federal de 1988, a proteção de direitos fundamentais tem como fundamento a proibição de discriminação em razão de sexo, de gênero ou de orientação sexual. Não por acaso, o texto constitucional de 1988 permitiu ao Brasil a ratificação e consequente incorporação no âmbito doméstico de uma série de tratados internacionais de direitos humanos, os quais servem de instrumentos para a denúncia de práticas discriminatórias e a promoção de não-violência.

A tentativa de negar vigência a normas nacionais e internacionais através da retirada de quaisquer referências à palavra "gênero" é inconstitucional, 
anti-democrática e ilegal, porque pretende a exclusão da proteção jurídica contra a discriminação e a violência a que estão mais facilmente submetidos determinados grupos sociais. Em uma democracia à moda brasileira, os parlamentos perderam uma ótima oportunidade para promoção de uma cultura de respeito às diferenças e de não-violência.

Outro argumento frequentemente veiculado é o de cerceamento à liberdade de expressão. No contexto de uma pretensão de formar todos os sujeitos para serem heterossexuais ou organizarem suas vidas a partir do modelo supostamente coerente, superior e "natural" da heterossexualidade ${ }^{8}$, a oposição sistemática a quaisquer outras possibilidades de orientação sexual seria, na visão desses grupos religiosos e conservadores, um direito fundado na liberdade de expressão. De novo, não se trata de ser contra ou favor, se trata da regra democrática de igual respeito e igual consideração a qualquer sujeito, independentemente de raça, sexo, cor, orientação sexual, etc. Tal reivindicação, baseada em uma noção de segregação de determinados grupos sociais, não pode ser admitida, tendo em vista que a Constituição Federal consagra a construção de uma sociedade livre, justa e solidária, isenta de quaisquer preconceitos.

Lourdes Bandeira e Anália Soria Batista (2002, p. 120-121) afirmam que, quando o Poder Público, através da elite política, favorece ou desfavorece determinados grupos identificados por sua etnia, raça, religião, sexo, região, etc., ele nega a legitimidade de existência e de expressão de outros segmentos, deixando as portas abertas às práticas preconceituosas e discriminatórias. Em outras palavras, nega a possibilidade do outro (da diferença) ter acesso à igualdade e à equidade:

Do ponto de vista jurídico, uma sociedade que prega a construção diferenciada e não-plural de seus membros, como signo do preconceito, que admite o acesso particularizado de alguns, seja aos bens materiais, seja aos bens culturais, que dá valoração

8 Sobre heterossexualidade compulsória, ver: MISKOLCI, Richard. A Teoria Queer e a Sociologia: o desafio de uma analítica da normalização. Sociologias, Porto Alegre, a. 11, n. 21, p. 150-182, jan./jun. 2009. De acordo com o autor, a heteronormatividade é um conjunto de prescrições que fundamentam processos sociais de regulação e controle de quaisquer práticas sexuais (Miskolci, 2009, p. 157). 
positiva à desigualdade substantiva de seus membros está fadada à instauração da violência nas suas variantes materiais e simbólicas (Bandeira; Batista, 2002, p. 121, grifos meus).

O sistema normativo constitucional brasileiro veda a censura de natureza política, ideológica ou artística às diversas formas de manifestação do pensamento (liberdade de expressão). A liberdade de expressão é um direito fundamental, decorrente da conjunção de diferentes dispositivos constitucionais. O Artigo $5^{\circ}$, inciso IV, dispõe que "é livre a manifestação do pensamento, sendo vedado o anonimato", e o inciso IX, que "é livre a expressão da atividade intelectual, artística, científica e de comunicação, independentemente de censura ou licença”. O Artigo 220, caput, garante que "a manifestação do pensamento, a criação, a expressão e a informação, sob qualquer forma, processo ou veículo não sofrerão qualquer restrição, observado o disposto na Constituição" e $\S 2^{\circ}$, diz que é "vedada toda e qualquer censura de natureza política, ideológica e artística”.

O fundamento do direito à liberdade de expressão, positivado no texto constitucional, está relacionado ao período de ditadura militar experimentado no Brasil em que havia uma violenta repressão a qualquer manifestação contrária ao regime político autoritário. Daí porque a ênfase do legislador constituinte na proibição a qualquer censura de natureza política, ideológica e artística.

Nesse sentido, afirmar que

a vitória da ideologia de gênero significaria a permissão de toda perversão sexual (incluindo o incesto e a pedofilia), a incriminação de qualquer oposição ao homossexualismo (crime de "homofobia"), a perda do controle dos pais sobre a educação dos filhos, a extinção da família e a transformação da sociedade em uma massa informe, apta a ser dominada por regimes totalitários (Zenit, 2014). ${ }^{9}$

9 Matéria do blog Zenit - o mundo visto de Roma: $O$ exemplo da Suécia, um país totalmente contaminado pela ideologia de gênero. Disponível em: < http://pt.zenit.org/articles/o-exemplo-da-suecia-um-pais-totalmente-contaminado-pelaideologia-de-genero/>. Acesso em: 25 jan. 2016. 
é se opor à implementação de políticas públicas educacionais de combate à violência ou à discriminação de gêneros, pactuadas pelo Estado brasileiro, a partir da Constituição Federal e da adesão a uma série de tratados e convencionais internacionais de direitos humanos. Muito longe do exercício regular da liberdade de manifestação, esse discurso está mais próximo de um hate speech (discursos de incitamento ao ódio) contra toda e qualquer pessoa que não se enquadra às normalizações de identidade de gênero e/ou de orientação sexual.

O Supremo Tribunal Federal foi chamado a se manifestar sobre um caso paradigmático para a compreensão do direito à liberdade de expressão (Habeas Corpus/RS, $\mathrm{n}^{\mathrm{o}}$ 82.424, conhecido como caso Ellwanger). Nesse julgado, o STF decidiu que a ordem constitucional impõe limites à liberdade de expressão, porque nenhum direito é absoluto e porque ninguém tem o direito de invocar a liberdade de expressão para emitir discursos racistas, antissemitas, xenófobos, etc. A seguir, selecionei alguns trechos que resumem o inteiro teor dessa decisão:

HABEAS-CORPUS. PUBLICAÇÃO DE LIVROS: ANTI-SEMITISMO. RACISMO. CRIME IMPRESCRITÍVEL. CONCEITUAÇÃO. ABRANGÊNCIA CONSTITUCIONAL. LIBERDADE DE EXPRESSÃO. LIMITES. ORDEM DENEGADA. 1. Escrever, editar, divulgar e comerciar livros "fazendo apologia de ideias preconceituosas e discriminatórias" contra a comunidade judaica (Lei 7716/89, artigo 20, na redação dada pela Lei 8081/90) constitui crime de racismo sujeito às cláusulas de inafiançabilidade e imprescritibilidade (CF, artigo $\left.5^{\circ}, \mathrm{XLII}\right)$. [...] 3. Raça humana. Subdivisão. Inexistência. Com a definição e o mapeamento do genoma humano, cientificamente não existem distinções entre os homens, seja pela segmentação da pele, formato dos olhos, altura, pêlos ou por quaisquer outras características físicas, visto que todos se qualificam como espécie humana. Não há diferenças biológicas entre os seres 
humanos. Na essência são todos iguais. 4. Raça e racismo. A divisão dos seres humanos em raças resulta de um processo de conteúdo meramente político-social. Desse pressuposto origina-se o racismo que, por sua vez, gera a discriminação e o preconceito segregacionista. 5. Fundamento do núcleo do pensamento do nacional-socialismo de que os judeus e os arianos formam raças distintas. Os primeiros seriam raça inferior, nefasta e infecta, características suficientes para justificar a segregação e o extermínio: irreconciabilidade com os padrões éticos e morais definidos na Carta Política do Brasil e do mundo contemporâneo, sob os quais se ergue e se harmoniza o estado democrático. Estigmas que por si só evidenciam crime de racismo. Concepção atentatória dos princípios nos quais se erige e se organiza a sociedade humana, baseada na respeitabilidade e dignidade do ser humano e de sua pacífica convivência no meio social. Condutas e evocações aéticas e imorais que implicam repulsiva ação estatal por se revestirem de densa intolerabilidade, de sorte a afrontar o ordenamento infraconstitucional e constitucional do País. 6. Adesão do Brasil a tratados e acordos multilaterais, que energicamente repudiam quaisquer discriminações raciais, aí compreendidas as distinções entre os homens por restrições ou preferências oriundas de raça, cor, credo, descendência ou origem nacional ou étnica, inspiradas na pretensa superioridade de um povo sobre outro, de que são exemplos a xenofobia, "negrofobia”, "islamafobia” e o anti-semitismo. 7. A Constituição Federal de 1988 impôs aos agentes de delitos dessa natureza, pela gravidade e repulsividade da ofensa, a cláusula de imprescritibilidade, para que fique, ad perpetuam rei memoriam, verberado o repúdio e a abjeção da sociedade nacional à sua prática. [...] 9. Direito comparado. A exemplo do Brasil as legislações de países organizados sob a égide do estado 
moderno de direito democrático igualmente adotam em seu ordenamento legal punições para delitos que estimulem $e$ propaguem segregação racial. Manifestações da Suprema Corte Norte-Americana, da Câmara dos Lordes da Inglaterra e da Corte de Apelação da Califórnia nos Estados Unidos que consagraram entendimento que aplicam sanções àqueles que transgridem as regras de boa convivência social com grupos humanos que simbolizem a prática de racismo. [...] 13. Liberdade de expressão. Garantia constitucional que não se tem como absoluta. Limites morais e jurídicos. $O$ direito à livre expressão não pode abrigar, em sua abrangência, manifestações de conteúdo imoral que implicam ilicitude penal. 14. As liberdades públicas não são incondicionais, por isso devem ser exercidas de maneira harmônica, observados os limites definidos na própria Constituição Federal $\left(\mathrm{CF}\right.$, artigo $5^{\circ}, \S$ $2^{\circ}$, primeira parte). $O$ preceito fundamental de liberdade de expressão não consagra o "direito à incitação ao racismo", dado que um direito individual não pode constituir-se em salvaguarda de condutas ilícitas, como sucede com os delitos contra a honra. Prevalência dos princípios da dignidade da pessoa humana e da igualdade jurídica. 15. [...] No estado de direito democrático devem ser intransigentemente respeitados os princípios que garantem a prevalência dos direitos humanos. Jamais podem se apagar da memória dos povos que se pretendam justos os atos repulsivos do passado que permitiram e incentivaram o ódio entre iguais por motivos raciais de torpeza inominável. 16. A ausência de prescrição nos crimes de racismo justifica-se como alerta grave para as gerações de hoje e de amanhã, para que se impeça a reinstauração de velhos e ultrapassados conceitos que a consciência jurídica e histórica não mais admitem. Ordem denegada. (STF, Pleno, HC 82424, Relator: Min. Moreira Alves, Relator p/ Acórdão: 
Afirmar que gênero na escola é ensinar "perversão" para crianças e adolescentes é, além de ignorância (no sentido de desconhecimento de fatos), uma forma de inculcar um estereótipo às defensoras e defensores de uma escola não indiferente à discriminação e à violência. Somos todos "pervertidas ou pervertidos" por que queremos uma escola que reconheça e respeite as diferenças?

Os discursos públicos de incitamento ao ódio contra mulheres, gays, lésbicas, travestis e transexuais violam o Estado Democrático de Direito, porque desrespeitam os princípios republicanos que garantem a prevalência dos direitos humanos, porque atentam contra o respeito à dignidade humana e o dever de igual respeito e igual consideração de todas e todos.

\section{CONSIDERAÇÕES FINAIS}

As demandas de reconhecimento das diferenças (de gênero, de raça/ etnia, de sexo, de orientação sexual, de classe, de pertencimento religioso, de origem territorial, das deficiências) se inserem em um contexto de ruptura com os processos de invisibilização e exclusão social e cultural. Dos debates nos parlamentos (federal, estadual e municipal) sobre os planos de educação emergiram questões muito importantes que vão além da suposta oposição entre escola (mundo da vida pública) e família (mundo da vida doméstica). Revelaram implicações para pensarmos sobre dignidade humana, igualdade e democracia no contexto contemporâneo brasileiro.

No campo legislativo, as recentes alterações nos planos de educação introduzem uma pseudo-neutralidade da escola quanto às pedagogias de gênero. Trata-se de uma forma de mascarar os problemas decorrentes dos processos de exclusão e violência reproduzidos no interior das famílias sobre corpos/sujeitos não conformados às convenções de gênero.

A inclusão dos debates de gênero no contexto escolar faz parte de legítimos anseios pela promoção da equidade de gênero, de uma vida livre 
de discriminação e de violência para meninas e meninos, jovens e adultos.

Os discursos de incitamento ao ódio estão na contramão dos esforços locais, regionais e globais de proteção e efetivação dos direitos humanos: violam marcos normativos, a partir dos quais reivindicamos igual respeito e consideração, reconhecimento do direito à existência digna, à liberdade e ao desenvolvimento para todas e todos.

\section{REFERÊNCIAS}

BANDEIRA, Lourdes; BATISTA, Anália Soria. Preconceito e discriminação como expressões de violência. Revista Estudos Feministas, v. 10, n.1, p. 119-141, 2002.

BARROSO, Luis Roberto. Curso de Direito Constitucional Contemporâneo: os conceitos fundamentais e a construção do novo modelo. 3.ed. São Paulo: Saraiva, 2011.

BRUM, Eliane. O aborto na fogueira eleitoral. Disponível em: <www.brasil.elpais.com/m/ brasil/2014/04/28/opinion/1398692471_063651.html>. Acesso em: 25 jan. 2016.

CARBONNIER, Jean. Flexible droit. 10 édition. Paris: LGDF, 2001.

COOK, Rebecca J.; CUSACK, Simone. Gender Stereotyping: transnational legal perspectives, University of Pennsylvania, 2009. Disponível em: < http://www.profamilia.org.co/images/stories/libros/estereotipos-de-genero.pdf $>$.

CORRÊA, Mariza. Do feminismo aos estudos de gênero no Brasil: um exemplo pessoal. Cadernos Pagu, n. 16, p. 13-30, 2001.

DINIZ, Débora. Perspectivas e articulações de uma pesquisa feminista. In: STEVENS, Cristina; OLIVEIRA, Susane Rodrigues de; ZANELLO, Valeska. Estudos feministas e de gênero: articulações e perspectivas. Florianópolis: Ed. Mulheres, p. 11-21, 2014.

FACCHINI NETO, Eugênio. Reflexões histórico-evolutivas sobre a constitucionalização do direito privado. In: SARLET, Ingo W. Constituição, Direitos Fundamentais e Direito Privado. Porto Alegre: Livraria do Advogado, p. 11-60, 2003.

LÔBO, Paulo Luiz Netto. Constitucionalização do direito civil. Revista de Informação Legislativa, Brasília, a. 36, n. 141, p. 99-109, jan./mar. 1999.

LOURO, Guacira Lopes. Gênero, sexualidade e educação: uma perspectiva pós-estruturalista. Petrópolis: Vozes, 1997.

MISKOLCI, Richard. A Teoria Queer e a Sociologia: o desafio de uma analítica da normalização. Sociologias, Porto Alegre, a. 11, n. 21, p. 150-182, jan./jun. 2009. 
OKIN, Susan. Gênero, o público e o privado. Estudos Feministas, Florianópolis, v. 16, n. 2, p. 305-312, maio/ago. 2008.

PELÚCIO, Larissa. Desfazendo o gênero. In: MISKOLCI, Richard; LEITE JUNIOR, Jorge (Orgs.). Diferenças na Educação: outros aprendizados. São Carlos: EdUFSCar, p. 97-148, 2014.

ROUDINESCO, Elisabeth. A família em desordem. Rio de Janeiro: Jorge Zahar Ed., 2003.

VENCATO, Anna Paula. Diferenças na escola. In: MISKOLCI, Richard; LEITE JUNIOR, Jorge (Orgs.). Diferenças na Educação: outros aprendizados. São Carlos: EdUFSCar, p. 19-56, 2014. 


\title{
DOMINAÇÃO MASCULINA: A VIOLÊNCIA SIMBÓLICA NOSSA DE CADA DIA
}

\author{
Elisa Girotti Celmer
}

\section{CONSIDERAÇÕES INICIAIS}

A partir dos estudos para a elaboração deste texto foi possível verificar que, embora a maioria dos estudos sobre violência contra as mulheres desenvolva conceitos a esse respeito, eles apresentam uma indistinção terminológica, fazendo certa confusão entre os termos "violência contra a mulher", "violência doméstica", "violência familiar" e "violência conjugal", os quais muitas vezes são utilizados como sinônimos, mesmo não o sendo. Conforme a Convenção de Belém do Pará, violência contra mulher é "qualquer ação ou conduta baseada no gênero, que cause morte, dano ou sofrimento físico, sexual ou psicológico à mulher, tanto no âmbito público como privado". O termo "violência contra a mulher", portanto, engloba a violência doméstica, a violência familiar e a violência conjugal.

Por violência doméstica deve-se entender aquela conduta que cause dano físico, psíquico ou sexual não só à mulher como a outras pessoas que coabitem na mesma casa, incluindo empregados e agregados. Já a violência familiar é mais específica, abrangendo apenas as agressões físicas ou psicológicas entre membros da mesma família. Por fim, violência conjugal 
deve ser entendida como todo tipo de agressão praticada contra cônjuge, companheira(o) ou namorada(o).

Não se deve restringir a violência conjugal àquela praticada pelo marido contra a esposa, pois sabidamente essas agressões alcançam também os casais de namorados, além de recentes pesquisas demonstrarem a existência de violência conjugal entre lésbicas, o que desnatura essa violência como sendo cometida exclusivamente pelos homens contra as mulheres (esposas, companheiras ou namoradas). Ademais, embora sejam poucos os casos registrados, existe também a violência conjugal praticada pela mulher contra o homem.

A Lei 11.340/06, conhecida como Lei Maria da Penha, nos incisos do Art. $5^{\circ}$, define violência doméstica ou familiar contra a mulher como sendo toda ação ou omissão, baseada no gênero, que cause morte, sofrimento físico, sexual ou psicológico e dano moral e patrimonial, no âmbito da unidade doméstica, da família e em qualquer relação íntima de afeto, em que o agressor conviva ou tenha convivido com a agredida. Ainda, no parágrafo único do referido artigo, há a ressalva de que as relações íntimas mencionadas independem de orientação sexual, do que se pode entender a possibilidade de o "agressor" também ser mulher, caso se trate de uma relação homossexual.

Da leitura do Art. $5^{\circ}$ da Lei 11.340/06 depreende-se que os dispositivos dessa lei deverão abarcar não só condutas que importem em delitos de lesão corporal (Art. 129, $\S 9^{\circ}$ do CP), mas todos os delitos praticados contra a mulher no âmbito doméstico ou familiar. Em suma, a apuração de qualquer tipo de violência em que a vítima seja mulher, desde que o(a) suposto(a) autor(a) do fato tenha com ela relações íntimas de afeto, deve ser regulada pela lei supracitada. Ademais, a Lei Maria da Penha, ao enumerar o dano moral e patrimonial como consequências da violência doméstica e familiar, engloba os casos de apropriações indébitas, furtos e outros delitos de cunho patrimonial praticados contra a mulher no âmbito doméstico, abrindo a possibilidade para se pleitear, inclusive, indenizações pelo dano moral. 
A expressão violência tem origem na palavra latina violentia, que significa ferocidade, arrebatamento, veemência, e no verbo violare, ultrajar, profanar, prejudicar, ferir (Faria, 1967, p. 1067).

Pensadores das mais diversas áreas, psicologia, filosofia, antropologia, sociologia, direito, etc., conceituam o que seja violência. Contudo, essa tarefa não é nada simples, pois a realidade que transborda das inúmeras expressões do constrangimento não consegue ser apreendida em um único conceito. Nesse sentido, seria mais adequado falar em violências, utilizando o plural, para uma aproximação do caráter multifacetado dos fenômenos violentos.

A antropóloga Alba Zaluar, ao tratar da expressão violência, diz o seguinte:

O termo violência vem do latim violentia, que remete a vis (força, vigor, emprego de força física, ou recurso do corpo para exercer sua força vital). Essa força torna-se violência quando ultrapassa um limite ou perturba acordos tácitos e regras que ordenam relações, adquirindo assim, carga negativa, ou maléfica. É a percepção do limite e da perturbação (e do sofrimento causado), que vai caracterizar um ato como violento, percepção que varia cultural e historicamente (Zaluar, 1999, p. 28).

A autora traz à baila a ideia de que há um grau aceitável de agressividade e que a percepção desse nível varia conforme o contexto histórico e a cultura da sociedade e dos indivíduos envolvidos nas violências. Sendo assim, a agressividade é inerente ao ser humano. As manifestações dessa agressividade, em maior ou menor grau, poderão ser aceitas socialmente, sendo muitas vezes consideradas "normais". Nesse sentido, pode-se "dizer que a violência é um elemento estrutural, intrínseco ao fato social e não um resto anacrônico de uma ordem bárbara em vias de extinção" (Gauer, 2003, p. 13).Por muito tempo as violências contra a mulher foram socialmente aceitas, o que impregnou as identidades culturais de homens e mulheres de 
um grau elevado de tolerância para com tais manifestações de agressividade. Essa aceitação sociocultural das violências contra a mulher foi tão bem alicerçada ao longo dos tempos que, até nos dias atuais, quando inclusive a legislação reprova essa forma de violência, as mulheres vitimizadas possuem dificuldade de reconhecer as agressões sofridas como sendo violência ${ }^{1}$.

A violência de gênero é a tradução das imposições baseadas na divisão sexual. Ao estabelecer o gênero masculino (e sua heteronormatividade) como medida de todos os gêneros, tal qual esse fosse neutro, a sociedade impõe sutilmente comportamentos, raciocínios, hábitos, gostos, espaços, profissões, lugares, etc. Essas formas de anulação (ou redução) identitária configuram o que pode ser chamado de violência de gênero, que vai da tênue determinação das cores das roupas de meninos e meninas até as agressões físicas fatais.

São as espécies mais sutis de constrangimento que serão abordadas adiante neste trabalho, por meio do estudo do conceito de violência simbólica de Pierre Bourdieu. Se agressões físicas e os abusos sexuais não são fáceis de serem reconhecidos como expressões de violência, o que dizer da violência simbólica nossa de cada dia!

\section{A MULHER EM SITUAÇÃO DE VIOLÊNCIA}

Interessante é analisar a etimologia dos vocábulos vítima e mulher, para perceber a origem da ligação entre eles. Uma das explicações diz que a palavra vítima adviria de vincere, que significaria vencer, ser vencedor, sendo a vítima aquele vencido, o derrotado, o abatido; e mulher teria derivado de mulier, que designaria a pessoa tímida, frágil, fraca. Nota-se que a associação feita entre vítima e mulher está calcada no significado dessas duas palavras. Dessa maneira, a mulher é vista e vê a si mesma como a fraca, a submissa; ou seja, a dominada.

\footnotetext{
1 Sobre a dificuldade do reconhecimento da violência pela mulher, ver SCHAIBER, Lilia Blima et al. Violência dói e não é direito: A violência contra a mulher, a saúde e os direitos humanos. São Paulo: Editora UNESP, 2005. p. 46-49.
} 
Tamanha é a preocupação do movimento feminista com a mulher na condição de vítima que há quem diga ser a vitimologia, uma questão exclusivamente feminina (Fernandes, 1995, p. 38). Reivindica-se maior proteção penal às mulheres, por meio de penas mais rigorosas, isto é, pena de prisão, restrições na progressão de regime, duração maior das condenações para os homens que praticam violência contra a mulher.

O termo mulher em situação de violência foi criado justamente para tentar desvincular as mulheres com a posição de eternas vítimas. Ademais, tal expressão é utilizada para designar mulheres que estão inseridas em um ambiente onde agressões são constantes.

Nos últimos vinte anos, o reconhecimento da violência contra a mulher como sendo um problema público vem ocorrendo na sociedade brasileira. Durante esse período, aconteceu uma politização do discurso relativo às práticas de violência contra a mulher, resultando em correntes de opinião que tendem a recorrer à criminalização e à punição dessas formas de violência. Simultaneamente, esse discurso punitivo dos movimentos de mulheres, em um cenário mais amplo, tem se confrontado com dois aspectos importantes da contemporaneidade: a crise do sistema de justiça criminal brasileiro e a falência do sistema punitivo. Contudo, quando um movimento social conhece um certo sucesso e perdura durante algumas décadas, mudanças, obviamente, acontecem. O entusiasmo inicial diminui, o "sucesso" do movimento não é estável: determinados temas levantados podem, às vezes, ser retomados e incorporados pela sociedade, esvaziando o caráter de tabu de tais assuntos e fazendo com que o discurso deixe de ser marginal e se torne dominante.

Por sua vez, o Estado, no intuito de se mostrar politicamente correto, encampou a defesa dos Direitos das Mulheres, institucionalizando alguns espaços de discussão dos movimentos feministas e de mulheres. Em decorrência dessa aproximação do movimento social com os órgãos estatais, está ocorrendo uma tendência maior de o Estado incorporar à legislação reivindicações feministas, mormente no que se refere à violência doméstica e familiar contra a mulher. 
Dentro desse contexto existem, em especial, duas leis: a Lei 10.886/2004, a qual inseriu no Código Penal o agravamento da lesão corporal em decorrência de violência doméstica, e a recente Lei 11.340/2006, que instituiu os Juizados da Violência Doméstica e familiar contra a mulher e, entre outras modificações, aumentou a pena do delito de lesão corporal decorrente de violência doméstica, bem como vedou a utilização do rito da Lei 9.099/95 para a apuração do referido delito.

A intenção aqui não é debater a Lei 11.340/2006 (Maria da Penha), nem os reflexos de sua implementação, mas levantar alguns tópicos mais polêmicos da referida legislação que são pertinentes para uma reflexão sobre as condições das mulheres em situação de violência. Será dado destaque à busca por entender as racionalidades que permeiam os atos dessas mulheres submersas em um contexto violento e que apresentam tanta dificuldade de se movimentar para fora desses ambientes opressores.

O fato de a maioria das mulheres em situação de violência não denunciar às autoridades seus agressores ou não manter as acusações quando, após a denúncia, fazendo o primeiro movimento para sair do contexto violento, retrata o então desejo de representar criminalmente contra o acusado é comportamento que causa grande incômodo e incompreensão entre quem se depara com o tema. Especialmente quando passam a existir instrumentos legais que, embora muitas vezes não sejam adequados ou suficientemente eficazes para seus intuitos, visam a proteção das mulheres em situação de vulnerabilidade.

Duas são as razões mais aventadas para explicar esse comportamento reiterado por mulheres em situação de violência: a dependência econômica do suposto agressor e as ameaças feitas pelo agressor caso elas denunciem ou continuem com o processo criminal.

Apesar de a dependência econômica ser aspecto relevante que leva inúmeras mulheres em situação de violência a retratarem-se da representação criminal, a dependência emocional, com seus múltiplos fatores, normalmente é a razão principal pela qual as mulheres não registram o fato ou desistem de processar o agressor. Viver sem um homem a lhes respaldar, a lhes dar 
a sensação de proteção, muitas vezes, é um temor suficiente para a mulher calar-se e manter a relação conjugal. Não obstante as mudanças e conquistas formais de direitos, a sociedade, aqui particularmente a brasileira, ainda exige o cumprimento de papéis de gênero pré-estabelecidos.

As mulheres, na sua maioria, ainda são educadas para serem esposas (boas esposas!); com isso, no íntimo dessas mulheres, o que passa é que se foram agredidas por seus companheiros é porque fizeram algo que não lhes agradou, frustraram a expectativa que seus papéis de esposa lhes impunha. Nessa linha, denunciar a violência às autoridades corresponde a reconhecer publicamente o fracasso de sua relação conjugal ${ }^{2}$. Daí vislumbra-se que a resistência das mulheres em situação de violência em denunciar essa condição não é despropositada, nem devida apenas à dependência econômica. $\mathrm{O}$ cuidado que se deve ter é de não se criarem mecanismos que, embora com o intuito de proteger, dificultem ainda mais às mulheres uma atitude de denunciar a situação de violência em que estão inseridas. Ainda, há que se investigar quais esquemas psicossociais estão relacionados a essa atitude de não denunciar o agressor, buscando compreender as racionalidades dessas mulheres e não as tratar como seres irracionais.

O argumento no sentido de que a vítima desiste da representação coagida por agressões e por isso deve o Ministério Público, incondicionalmente, ser o titular da ação penal para apurar esses casos leva à seguinte indagação: não continuará ela sendo agredida e ameaçada assim que seu suposto agressor tomar conhecimento de que está sendo processado criminalmente? Não se estará apenas transferindo o momento da coação, ou até piorando, pois o que antes era ameaça agora será agressão de fato? O processo penal não é instrumento adequado para dar proteção à mulher vítima. Não se discorda que sendo a violência contra as mulheres um problema, inclusive de saúde pública, o Estado deva dispor de mecanismos que as protejam contra tal violência. Contudo, isso deve ocorrer através de políticas públicas e da aplicação das medidas protetivas previstas na Lei 11.340/06. Da análise do modo como se opera esse tipo de violência, percebe-se que pouco, ou

2 Sobre esse tema específico, ler: LARRAURI, Elena. ¿Por qué las mujeres maltratadas retiran las denuncias? In: Mujeres y Sistema Penal: violência doméstica. Montevidéu: B de F, 2008. p. 127. 
nada, irá ajudar a ação penal ser de iniciativa pública incondicionada se não aplicadas a ela medidas efetivas de proteção, pois o suposto agressor continuará coabitando com a vítima e sendo pai de seus filhos, vínculo que não cessa nunca.

O tema é complexo e delicado, já que as consequências são maiores do que um reflexo apenas processual. Raros são os casos de violência doméstica e familiar contra a mulher que ocorrem sob os olhares de terceiros alheios ao conflito que possam denunciar o fato; a maioria esmagadora dessa espécie de violência acontece ao abrigo da publicidade e só é denunciada às autoridades se a vítima o fizer. A dificuldade de fazer a denúncia é imensa devido ao vínculo que possui com o agressor, mesmo sabendo da possibilidade de não processar ou "desistir do processo" mais tarde. Ao se instituir a prescindibilidade da representação e a inevitabilidade do processo penal com o registro da noticia criminis, certamente a atitude de denunciar a situação de violência em que estão inseridas será muito mais difícil de ser tomada pelas mulheres.

\section{DOMINAÇÃO MASCULINA E VIOLÊNCIA SIMBÓLICA}

A dominação masculina, para Bourdieu (2005), é um fenômeno decorrente da violência simbólica construída historicamente de forma autoritária, mas um tanto sutil. Isso porque a separação e a hierarquização entre os sexos foram infiltradas de tal maneira na ordem das coisas, que se apresentam como se naturais fossem, sendo introjetadas e reproduzidas por homens e mulheres por meio do que Bourdieu chama de habitus.

O habitus seria a trama resultante da mediação entre as estruturas sociais e as disposições individuais; da articulação entre essas duas dimensões sociais são produzidas disposições duráveis. As estruturas sociais tornam-se estruturas cognitivas; dessa forma, objetiva e subjetivamente, a ordem social se reproduz pelos modos de sentir, pensar e agir, os quais estão em um esquema de percepção. O habitus não é, contudo, algo estático, uma vez que 
é criado socialmente, sendo resultado de um longo e intenso processo de incorporação de significados nos corpos e mentes das pessoas.

A ideia de habitus é útil para pensar que existe uma matriz cultural que propicia aos indivíduos fazerem suas escolhas, ou seja, que as escolhas nunca são totalmente livres e individuais. Na conformação dessa matriz cultural possuem papel relevante as instituições sociais como a família, as igrejas, a escola e, na atualidade, especialmente, a mídia. Bourdieu (2005) critica, principalmente, a Escola, pois essa deveria promover uma socialização capaz de superar desigualdades sociais - dentre as quais a de gênero -, porém não o faz, reproduzindo as desigualdades ao não habilitar suficientemente os(as) jovens a transpor os obstáculos sociais e culturais.

A partir de sua pesquisa etnográfica na comunidade camponesa da Cabília, situada no norte da África, Bourdieu (2005) estabelece as bases para sua explicação da dominação masculina, destacando os conceitos de habitus e socialização. Estudar o comportamento dos camponeses e das camponesas da Cabília trouxe para o autor a conclusão de que estes indivíduos mantinham estruturas representativas da perspectiva androcêntrica habituais em todas as sociedades mediterrâneas. Com base nas observações da dinâmica social da comunidade Cabilia, Bourdieu (2005) compreende e explica a dominação masculina nas sociedades contemporâneas.

A divisão (e hierarquização) entre os sexos é naturalizada, aparenta ser inevitável e neutra. Uma vez incorporada essa organização natural das coisas, a justificação da força da ordem masculina é dispensável. Essa ordem masculina como medida para todas as coisas é a principal face da dominação masculina, que muitos dizem estar superada, mas persiste no cotidiano de mulheres e homens.

Instituições sociais tais como o Estado, a Igreja e a Escola são as principais responsáveis pela dinâmica de retroalimentação das estruturas objetivas e subjetivas da dominação masculina. Quando os(as) dominados(as) desenvolvem seus pensamentos e suas percepções em consonância com as mesmas estruturas da relação de dominação que lhes foi imposta seus atos de 
conhecimento são, invariavelmente, atos de reconhecimento da submissão (Bourdieu, 2005, p. 22).

Há brechas nesta correspondência entre as realidades e as divisões que lhes são aplicadas que possibilitam aos(às) dominados(as) resistirem, disputando o sentido das relações de gênero. A definição dos órgãos sexuais, assim, não é algo dado pela simples descrição de características naturais, mas produto de uma construção social realizada pela acentuação de algumas diferenças e a ocultação de algumas semelhanças. O falo, então, é instituído como símbolo de virilidade pela perspectiva de mundo que se alicerça na divisão e hierarquização dos gêneros.

Ao tratar da relação entre os sexos, Bourdieu (2005) mostra que a designação do masculino-ativo e do feminino-passivo extrapolou o âmbito da intimidade e alcançou todas as áreas da vida social. Essa divisão, que se tornou um princípio, acabou sendo aplicada no sentido de direcionar o desejo masculino para a posse e o desejo feminino para uma subordinação erotizada. Existe um processo coletivo de socialização difusa que inscreve nos corpos as relações sociais de dominação; portanto, são as diferenças biológicas que são explicadas pelas diferenças sociais - e não o contrário.

Apesar das liberdades formais, tais como direito ao voto, à educação, o acesso ao mercado de trabalho, bem como da popularização dos métodos anticoncepcionais, os corpos e mentes das mulheres continuam submissos ao olhar masculino. Bourdieu (2005) alerta para essas permanências dentro das mudanças; as mulheres conseguem se profissionalizar, mas as ocupações "feminilizadas" são desvalorizadas. Ainda que as mulheres, atualmente, tenham acesso às funções públicas, constantemente são posições desprestigiadas, além de terem remunerações menores do que a dos homens, mesmo desempenhando as mesmas tarefas.

As profissões majoritariamente ocupadas pelas mulheres, nos dias atuais, ainda estão situadas nas áreas dominadas pela lógica tradicional do modelo de divisão masculino/feminino. Assim, as ocupações das mulheres no espaço público permanecem sendo extensões de suas tarefas domésticas, ou seja, funções relacionadas ao cuidado: magistério do ensino 
básico, enfermagem, serviços de limpeza. Ocupações muito relevantes, porém extremamente desprestigiadas socialmente, tanto em relação ao status quanto à remuneração.

Outra área profissional bastante ocupada por mulheres que também é uma ampliação do âmbito doméstico é a de apresentação, representação e acolhida: recepcionistas, modelos, propagandistas, aeromoças, hostess. Nesses casos, Bourdieu (2005) destaca a atenção extrema que essas mulheres precisam dispensar para com a aparência física, pois tais profissões ou papéis sociais que lhes são reservados importam em uma boa dose de sedução explícita ou implícita.

As categorias construídas desde a lógica da dominação masculina são aplicadas pelas mulheres às relações sociais, fazendo com que tais categorias sejam percebidas como naturais, neutras e indiscutíveis. Nesse sentido,

A violência simbólica se impõe por intermédio da adesão que o dominado não pode deixar de conceder ao dominante (e, portanto, à dominação) quando ele não dispõe, para pensá-la e para se pensar, ou melhor, para pensar sua relação com ele, mais que instrumentos de conhecimento que ambos têm em comum e que, não sendo mais que a forma incorporada da relação de dominação, fazem esta relação ser vista como natural; ou, em outros termos, quando os esquemas que ele põe em ação para se ver e se avaliar, ou para ver e avaliar os dominantes (elevado/baixo, masculino/feminino; branco/negro etc.), resultam da incorporação de classificações, assim naturalizadas, de que seu ser social é produto (Bourdieu, 2005, p. 47).

Essas incorporações alcançam também os homens, que acabam sendo prisioneiros das representações da dominação masculina. A virilidade é a principal dessas representações; ela precisa ser conservada a qualquer custo pelos homens. A virilidade se desdobra para além do aspecto físico ou 
reprodutivo, se traduz em constante coragem moral. A exigência de que os homens exerçam habilidades reprodutivas, sociais e tenham disposição para a agressividade é algo que sobrecarrega muitos homens. Com isto, notase que Bourdieu (2005) destaca a questão relacional da problemática da dominação entre os homens e as mulheres.

A percepção que grande parte das mulheres possui do próprio corpo segue os ditames da moda; o padrão imposto pela moda é uma força simbólica que parece natural, mas é produto da dominação masculina. De acordo com Bourdieu (2005, p. 50), uma força simbólica pode ser caracterizada como uma forma de poder que é exercida sobre os corpos e mentes sem nenhuma coação física, tal qual espécie de magia que só é eficaz porque se vale do apoio das predisposições incorporadas historicamente nos pontos mais profundos dos indivíduos. Assim, a força simbólica das coisas, dos atos e das emoções se exerce por meio de um gasto muito pequeno de energia, pois ela encontra respaldo no contínuo trabalho prévio de produção de disposições duradouras que ela desperta.

Se a noção de virilidade tem a força simbólica de ser associada ao poder, a feminilidade, por oposição, remete à ideia de tudo o que não se refere ao poder. Isso coloca as mulheres, frequentemente, em uma posição hesitante: se demonstram atributos viris para acessarem o poder, se afastam dos requisitos da feminilidade, mas se não o fazem são taxadas de inaptas para lidar com situações que envolvam poder.

Tendo em conta a profunda inscrição da força simbólica da dominação nos corpos, Bourdieu (2005) previne que, para a mudança das predisposições do habitus, não basta apenas uma tomada de consciência a respeito da dominação, pois tais forças estão inculcadas no mais íntimo dos corpos, sob as formas das vocações e desejos. Contudo, a tomada de consciência é o primeiro passo para uma mudança, pois não há como transformar um problema, sem antes reconhecer a sua existência. 


\section{CONSIDERAÇÕES FINAIS}

A violência simbólica pode ser entendida como expressões de crenças historicamente construídas para fundamentar relações de dominação e a peculiaridade dessa forma de violência é que as(os) dominadas(os) são parte essencial na reprodução das situações de opressão às quais estão submetidas(os). Assim, comportamentos que inibem a criatividade podem ser considerados simbolicamente violentos, pois restringem a liberdade de expressão ao se basearem em papéis sociais de gênero (homem/mulher) pré-fixados (Bourdieu, 2005).

Situações de violência simbólica são as mais corriqueiras no cotidiano das mulheres. Ainda que jamais tenham sido vítimas de agressões físicas ou psicológicas, dificilmente passaram ilesas a um episódio de violência simbólica. A clássica frase “isso não é coisa de menina” é expressão clara de violência simbólica. Outros exemplos podem ser descritos, tais como o estabelecimento de tarefas domésticas a serem desempenhadas exclusivamente por mulheres; o privilégio na escolha de homens para ocuparem cargos de chefia ou o pagamento de salários mais baixos às mulheres quando elas ocupam tais cargos.

O tema da violência é extremamente complexo. As manifestações agressivas envolvem fatores biopsicossociais; especificamente em relação à violência contra as mulheres, os aspectos psicológicos e sociais imbricados entre si são os que ganham maior evidência. Contudo, as articulações desses fatores são mecanismos muito sutis, embora muitas vezes suas expressões sejam bem contundentes quando se tornam marcas físicas e essa sutileza com que esses aspectos se encadeiam de modo a produzir violências faz desse assunto algo complexo, tal qual um novelo de lã multicolorido totalmente emaranhado que precisa ser desenredado para então poder se começar a tecer; pensar em soluções para a violência contra as mulheres passa por descobrir as pontas do novelo. Tentar identificar quais comportamentos (comissivos ou omissivos) importam violência é o percurso inicial no caminho para compreensão do fenômeno da violência contra as mulheres. 
Ao se compreender o fenômeno da violência contra as mulheres com suas peculiaridades, especialmente no que diz respeito à violência doméstica, nota-se que, quanto menor a intervenção estatal de cunho penal, menos traumas ocorrerão. Não se trata de privilegiar o suposto agressor, mas de pensar segundo a perspectiva da redução de danos para a vítima, que nesses casos está intimamente envolvida com o acusado.

Certo é que uma abordagem mais adequada da violência doméstica deve levar em conta também a agressão como uma relação de poder, entendendo o poder não como algo absoluto e estático, exercido invariavelmente pelo homem sobre a mulher, mas como algo fluído que perpassa a dinâmica relacional, exercido ora por homens, ora por mulheres. Ainda, é importante reconhecer os limites do Direito Penal para alcançar resultados efetivos no combate à violência contra a mulher, a fim de viabilizar a construção de novas possibilidades de enfretamento dos conflitos de gênero de acordo com novos modelos de justiça.

Os aspectos socioculturais influenciam na construção dos aspectos psicológicos dos seres humanos; esses aspectos, por sua vez, auxiliarão na reprodução da cultura. Enquanto as violências estiverem arraigadas nos seres como maneira preponderante de comunicação, as situações de violência irão continuar. Transformar padrões culturais é uma das mais árduas tarefas de serem operadas, pois desestruturam certezas até então consolidadas.

A busca de mecanismos para diminuir a violência contra a mulher passa por identificar os elementos que compõem esses esquemas de reprodução de contextos violentos. Assim, como as instituições, segundo Bourdieu (2005), possuem responsabilidade na reprodução do habitus que produz a dominação masculina, elas também têm papel relevante para a sua desconstrução. A escola é, talvez, a instituição com maior potencial de ensejar transformações, mas para tanto é preciso que os agentes que compõem os espaços de ensino percebam a sutileza da violência simbólica e promovam ações políticas que levem em conta o maior número possível dos efeitos da dominação masculina, para que, em longo prazo e paulatinamente, tal dominação vá desaparecendo. Assumir uma postura em sala de aula de não reiterar desigualdade de gênero e promover o debate sobre as formas de 
violência de gênero, obviamente, com os recursos pedagógicos adequados a cada faixa etária, é um bom começo dessas transformações.

\section{REFERÊNCIAS}

BOURDIEU, Pierre. A dominação Masculina. Traduzido por: Maria Helena Kühner. 4. ed. Rio de Janeiro: Bertrand Brasil, 2005.

CONVENÇÃO INTERAMERICANA para prevenir, punir e erradicar a violência contra a mulher - Convenção de Belém do Pará, 1994.

FARIA, Ernesto (Org.). Dicionário Escolar Latim-Português. 4. ed. Rio de Janeiro: Departamento Nacional de Educação/Ministério da Educação e Cultura, 1967.

FERNANDES, Antônio Scarance. O papel da vítima no processo penal. São Paulo: Malheiros, 1995.

GAUER, Ruth Chittó. Fenomenologia da violência. Curitiba: Juruá, 2003.

LARRAURI, Elena. ¿Por qué las mujeres maltratadas retiran las denuncias? In: Mujeres y Sistema Penal: violência doméstica. Montividéu: B de F, 2008.

SCHAIBER, Lilia Blima et al. Violência dói e não é direito: A violência contra a mulher, a saúde e os direitos humanos. São Paulo: Editora UNESP, 2005.

ZALUAR, A. M. Violência e Crime. In: Sergio Miceli. (Org.). O que ler na Ciência Social brasileira (1970-1995). São Paulo: Editora Sumaré/ANPOCS, 1999, v. 1, p. 15-107. 



\title{
SEXUALIDADE E JUVENTUDE: PEGAR, FICAR E NAMORO
}

\author{
Paula Pinhal de Carlos
}

\section{INTRODUÇÃO}

Este texto é um extrato de minha tese de doutorado, intitulada 'Sou para casar' ou 'pego, mas não me apego': práticas afetivas e representações de jovens sobre amor, sexualidade e conjugalidade, orientada por Miriam Pillar Grossi, coorientada por Mara Coelho de Souza Lago e defendida em 2011 no Programa de Pós-graduação Interdisciplinar em Ciências Humanas da Universidade Federal de Santa Catarina. Tratou-se de uma pesquisa multissituada (MARCUS, 1995) realizada com jovens de 13 a 18 anos, de ambos os sexos, alunos de escolas públicas. Parte dela foi desenvolvida em Florianópolis e na cidade de São José, pertencente à Região Metropolitana.

A partir de oficinas, observações e entrevistas, foi possível perceber que, dentre as práticas afetivas de jovens, três conceitos eram muito importantes: pegar, ficar e namoro. O pegar e o ficar parecem exemplificar muito bem aquilo que Bauman (2004) denomina de "amor líquido", devido à fluidez e à instabilidade, unidas ao desapego e mesmo a uma noção de descartabilidade das relações. Neste texto, procuro traçar considerações acerca do conceito de juventude e sua relação com a sexualidade, para 
então adentrar nas categorias específicas da sexualidade juvenil estudadas, privilegiando as noções de pegar e ficar.

\section{CONSIDERAÇÕES SOBRE O CONCEITO DE JUVENTUDE}

Para tratar dessa temática, faz-se necessário compreender de que forma surge o conceito de juventude. Além disso, é preciso refletir sobre a relevância de estudá-la. Para Peralva (2007, p. 25),

[...] enquanto o adulto vive ainda sob o impacto de um modelo de sociedade que se decompõe, o jovem já vive em um mundo radicalmente novo, cujas categorias de inteligibilidade ele ajuda a construir. Interrogar essas categorias permite não somente uma melhor compreensão do universo de referências de um grupo etário particular, mas também da nova sociedade transformada pela mutação.

Também Novaes (2007) entende que estudar a juventude auxilia na compreensão dos valores da contemporaneidade. Tendo por base tais entendimentos, acredito que pesquisar práticas afetivas de jovens permite não só averiguar as vivências relacionadas à sexualidade juvenil, mas também entender as modificações ocorridas nos relacionamentos amorosos na atualidade.

Para situar historicamente o conceito de juventude, é preciso inicialmente remeter à invenção da infância, a qual, segundo Ariès (1981), estaria situada nos fins do século XVIII. O autor demonstra que, anteriormente a tal período, as crianças eram vistas como adultos em miniatura, não sendo reservados a elas cuidados especiais. A infância é representada como categoria construída socialmente no momento em que as crianças passaram a ser vistas como seres frágeis e vulneráveis que, por esse motivo, possuíam necessidades específicas. Tomando-se como exemplo sua obra, é possível deduzir que também a categoria juventude inexistia nesse momento histórico. Não havendo uma diferenciação entre crianças e 
adultos, tampouco poderia estar presente a juventude, etapa intermediária entre a vida infantil e adulta.

Também se torna imperativo falar de Mead (1961) e o texto publicado em 1928 no qual compara a juventude de Samoa. Em sua pesquisa, a antropóloga compara as vivências juvenis de Samoa com as dos jovens americanos. Um dos destaques é dado justamente à questão da sexualidade, já que os jovens e as jovens de Samoa desfrutavam de uma liberdade sexual, algo muito diferente da situação dos Estados Unidos na época.

Em que momento histórico se situa, então, o advento da noção atual de juventude? Segundo Reguillo (2003), a categoria juventude, da forma como a conhecemos atualmente, consiste numa invenção operada após a Segunda Guerra Mundial, contexto no qual tomavam forma um discurso jurídico, um discurso escolar e uma indústria que reivindicava que crianças e jovens fossem tidos como sujeitos de direitos ${ }^{1}$ e, especialmente no caso dos jovens, de consumo.

Seguindo esses autores, se a invenção da infância pode ser localizada no final do século XVIII, a da juventude pode ser identificada na metade do século XX. É após a Segunda Guerra Mundial e diante do reconhecimento do holocausto nazista que se busca o reconhecimento da universalidade dos direitos humanos. Em virtude da discriminação operada durante o conflito, que diferenciava judeus, ciganos, homossexuais, deficientes físicos, crianças e idosos, por exemplo, como seres que não mereciam viver, a Organização das Nações Unidas, com a promulgação da Declaração Universal dos Direitos Humanos, busca a extensão e a garantia desses direitos a todas as pessoas e, portanto, também a crianças e jovens.

Nesse momento, com as economias abaladas pela participação na guerra, era preciso também a reestruturação, o que foi operado inclusive pelo consumo. Ser jovem, nesse momento, passou também a significar poder adquirir bens de consumo específicos para essa faixa etária. Isso é ressaltado por Louro (2000), que afirma que, no Brasil dos anos 1950, a juventude tinha como base os padrões de referência e estética da juventude

1 O sujeito de direitos pode ser compreendido como ente (individual ou coletivo) que é titular de direitos e deveres conferidos pelo ordenamento jurídico. 
estadunidense, que nesse momento se tornava um mercado de consumo distinto do mercado adulto.

A noção de juventude criada no pós-guerra também possui reflexos muito importantes para a geração de jovens dos anos 1960, lembrada pela quebra de diversos paradigmas no que diz respeito a gênero, sexualidade e preconceito racial, por exemplo. Para Cardoso (2005), a geração dos anos 1960 é crucial para o desenvolvimento do que a autora chama de “entronização do modo jovem de ser como estilo de vida” (p. 93), que é uma de suas características. Ela é oriunda, também, segundo a socióloga, da flexibilização das hierarquias e da autoridade, a qual gerou novas relações entre adultos e jovens.

Salienta-se que essas novas relações, com a flexibilização da autoridade adulta, também estão profundamente conectadas ao reconhecimento dos jovens como sujeitos de direitos. Reconhece-se, dessa forma, que jovens possuem direitos que são universais e devem ser respeitados, motivos pelos quais a autoridade adulta, independentemente de sua origem, se familiar ou educacional, por exemplo, não é ilimitada.

A juventude passa a ser, portanto, também uma referência, inclusive com padrões específicos de estética. Ela não é mais apenas uma faixa etária e, muito menos, um período da vida disposto entre a infância e a vida adulta. Ser jovem é poder questionar e quebrar barreiras. Por esse motivo, no século XX, a juventude é também um ideal a ser alcançado (Ariès, 1981).

Nota-se que a noção de juventude não está restrita à delimitação de uma faixa etária. Segundo os ensinamentos de Groppo (2000), ela não pode ser compreendida apenas sob esse prisma. A juventude deve ser tida também como representação social e cultural, bem como situação social. Dessa maneira, embora o fator idade seja importante para sua definição, a noção de juventude é muito mais ampla, envolvendo aspectos sociais e culturais.

O que caracteriza, então, a juventude? Como defini-la? Entendo que, para tanto, é preciso primeiramente remeter à noção sociológica clássica de Foracchi (1965), que caracteriza a juventude a partir do reconhecimento de 
que se trata de uma fase da vida, da constatação de sua força social renovadora

e da percepção de que vai além de uma etapa cronológica, constituindo-se também como um estilo próprio de existência.

Estão presentes em seu conceito elementos já apontados aqui, quais sejam: a juventude é também, mas não só, uma fase cronologicamente datada da vida das pessoas. Ela possui um estilo próprio (ser jovem não é apenas possuir determinada idade, mas ser de determinado jeito). Há, por fim, o caráter de mudança social que a juventude carrega consigo, tão visível, por exemplo, na geração dos anos 1960. É esse caráter de quebra de paradigmas, de renovação, que muitas vezes faz com que, nos dizeres de Giroux (1996), a juventude possua um caráter paradoxal, pois ao mesmo tempo em que é exaltada, é também demonizada.

Segundo Galland (1997), a juventude seria o período da vida que se estenderia até que eventos como o advento de um emprego em período integral, da conjugalidade, da parentalidade ou da constituição de uma residência autônoma da família de origem ocorram. Nota-se, aqui, que trabalho e família seriam dois norteadores importantes da vida adulta. Logo, é a admissão em um emprego, e em período integral, que poderia caracterizar o término da juventude.

Sobre a delimitação da juventude, Magnani (2005, p. 174) também afirma que "essa etapa pode ser marcada tanto por fatores biopsicológicos como por rituais de passagem, de mudança de status e ingresso em esferas específicas, como o mercado de trabalho, a constituição de família, o pertencimento a grupos, etc.”. No entanto, ele propõe que a juventude não seja tomada como categoria explicativa, mas como o ponto de partida empírico para os recortes efetuados nas pesquisas.

Ponto de vista semelhante possui Weller (2005, p. 112), que afirma que,

[...] se quisermos entender o que vem a ser juventude e como ela é vivida de fato pelos adolescentes e jovens de ambos os sexos, será necessário dedicar maior importância às descrições e narrativas dos atores en- 
volvidos, associada à reflexão teórico-metodológica e à análise rigorosa dos dados empíricos.

Também Foracchi (1965, p. 302) já apontava para a necessidade de se pensar a juventude como um fenômeno plural, ao sinalizar que "cada sociedade constitui o jovem à sua imagem”, bem como que uma sociedade pode produzir diversos tipos de jovens.

Percebe-se dessa forma que, por possuir contornos extremamente complexos e limiares tênues, é preciso sempre ter o cuidado de tratar de juventude de forma plural. É preciso compreender que a juventude não é uma experiência única e que, pelo contrário, possui diversas matizes que variam de época para época, de sociedade para sociedade e, ainda, dentro de uma mesma época e de uma mesma sociedade, variam por fatores como gênero, etnia, classe social, etc.

A categoria juventude está fortemente atrelada às ciências sociais, uma vez que difundida como

[...] momento de transição no ciclo de vida, da infância para a maturidade, que corresponde a um momento específico e dramático de socialização, em que os indivíduos processam a sua integração e se tornam membros da sociedade, por meio da aquisição de elementos apropriados da 'cultura' e da assunção de papéis adultos (Abramo, 2007, p. 79).

Esse conceito contrasta em certa medida com o de adolescência, mais difundido no campo da Psicologia. É preciso frisar que o conceito nativo utilizado pelos jovens pesquisados é adolescente, ou seja, é como adolescentes que eles se denominam, o que denota a aceitação desse conceito no meio social. Lago (1998, p. 262) assim o descreve:

A adolescência é a etapa da vida que tem início com as mudanças fisiológicas da puberdade - quando as glândulas sexuais começam a produzir os hormônios que vão desenvolver as características sexuais secun- 
dárias, reforçando biologicamente a diferenciação sexual - e termina somente quando se atinge um certo nível de maturação psicológica e social, que pressupõe a relativa independência do adulto jovem. Em nossas sociedades, caracteriza-se como um período de crise psicossocial, um tempo em que o jovem deve realizar a passagem da infância para a vida adulta.

Os conceitos de juventude e adolescência são também semelhantes. Em ambos os casos procura-se demarcar uma fase compreendida entre a infância e a vida adulta. Além disso, ressalta-se que a noção de crise também se faz presente tanto na ideia de juventude quanto na de adolescência. Por fim, também se faz presente nos dois casos a questão da aquisição de maturidade, seja psicológica ou social.

\section{PEGAR, FICARE NAMORO COMO MANIFESTAÇÕES DA SEXUALIDADE JUVENIL}

No intuito de tratar da sexualidade juvenil, torna-se imperativo primeiramente realizar algumas considerações sobre a sexualidade. Neste trabalho, a sexualidade será concebida como uma construção social, portanto determinada histórica e culturalmente. Nesse sentido, considera-se, com Vance (1995), que aquilo que é aceitável, ou seja, aquilo que é considerado normal ou natural é variável conforme a época, o local e a cultura.

Para Foucault (1988, p. 100), a sexualidade deve ser vista como um dispositivo histórico:

Não se deve concebê-la como uma espécie de dado da natureza que o poder é tentado a pôr em xeque, ou como um domínio obscuro que o saber tentaria, pouco a pouco, desvelar. A sexualidade é o nome que se pode dar a um dispositivo histórico: não à realidade subterrânea que se apreende com dificuldade, mas à grande rede da superfície em que a 
estimulação dos corpos, a intensificação dos prazeres, a incitação do discurso, a formação dos conhecimentos, o reforço dos controles e das resistências, encadeiam-se uns aos outros, segundo algumas estratégias de saber e poder.

No mesmo sentido são os dizeres de Weeks (2001), para quem a sexualidade só pode ser compreendida num contexto histórico específico, sendo preciso, ainda, compreender as relações de poder que interferem nos comportamentos considerados normais ou aceitáveis. Também Louro (1997) entende que a sexualidade é uma invenção social, constituída historicamente e a partir de discursos reguladores sobre o sexo. Logo, segundo a autora, é a partir dos processos culturais que é definido o que é ou não natural em determinada sociedade e em determinada época.

Esses autores, baseados em Foucault, tratam da sexualidade como uma construção e como circunscrita às relações de poder; conforme afirma Giddens (1993, p. 33), "a sexualidade é uma elaboração social que opera dentro dos campos do poder, e não simplesmente um conjunto de estímulos biológicos que encontram ou não uma liberação direta”. Rubin também rejeita o que chama de "essencialismo sexual" (2010, p. 10), compreendendo que a sexualidade é histórica e socialmente construída e não biologicamente determinada: "[i] sso não significa que as capacidades biológicas não são pré-requisito para a sexualidade humana. Significa que a sexualidade humana não é compreensível em termos puramente biológicos" (Rubin, 2010, p. 11).

A esse conjunto de autores também se une Ferrand (2004), que entende a sexualidade como aquilo que compreende as práticas sexuais físicas e corporais, bem como as relações e interações sociais provocadas por ela. Nesses significados, estariam inseridos as representações e os afetos, dentre outros. Para Bozon (2009), é a sociedade que produz a sexualidade humana, a qual, diferentemente da dos animais, não é instintiva, mas culturalmente construída. A sexualidade é compreendida ainda como sendo relacionada aos atos, às relações e às significações. 
É também Bozon (2009) quem traz importantes elementos para a compreensão da sexualidade juvenil. Para o sociólogo, a adolescência consistiria num período de preparação e aprendizagem da sexualidade, sendo que a juventude seria considerada como uma nova etapa para a qual a passagem à sexualidade genital seria decisiva. A construção da autonomia, que seria central na adolescência, se basearia na constituição de uma esfera pessoal, constituída por relações que escapam às instituições familiar e escolar: as relações com os amigos e as relações amorosas e sexuais. Numa entrevista concedida sobre gerações e sexualidade (Bessin, 2009), Bozon também assevera que após os anos 1980 a sexualidade juvenil passa a ter um estatuto diferenciado, pois a vida sexual regular é tida como um estabilizador da vida dos jovens. Por esse motivo, estaria presente uma cumplicidade dos pais em relação à vida sexual dos filhos (Bozon, 2009), modificando as normas de passagem à sexualidade adulta (Bozon, 2001).

\subsection{Pegar e Ficar}

No que se refere à prática de pegar, apenas um trabalho tratando do tema foi encontrado: o artigo científico de Oliveira et al (2007), publicado na Revista Brasileira de Enfermagem com o título Pegar, ficar e namorar: representaçôes sociais de relacionamentos entre adolescentes. Esse texto traz os resultados de uma pesquisa realizada com 130 estudantes de duas escolas públicas estaduais do Rio de Janeiro. De acordo com os jovens que participaram da pesquisa, o pegar é algo geralmente associado ao beijo, ainda que possa resultar inclusive numa relação sexual. Essa prática seria baseada, ainda, na espontaneidade e no descompromisso.

Já sobre o ficar há diversos trabalhos. Se a noção do ficar emerge no final dos anos 1980 (Schuch, 2002, p. 282), é principalmente na segunda metade da década de 1990 que estão concentrados os trabalhos acadêmicos sobre o tema. Cabe aqui citar as dissertações de mestrado de Giongo (1998) sobre jovens estudantes de uma escola de classe média alta de Porto Alegre, e de Schuch (1998) sobre jovens universitários da mesma localidade. Destaco 
ainda os artigos de Weingartner et al (1995) sobre as diferenças entre ficar e namorar, e de Guareschi (1999) sobre ficar e relações de gênero.

Esses trabalhos não cessam nessa década e há também nos anos 2000 referências sobre o ficar. São eles a pesquisa GRAVAD, realizada em Porto Alegre, Rio de Janeiro e Salvador (Heilborn et al., 2006) e a pesquisa de Jesus (2005), sobre adolescentes de Aracaju. Ambas tratam do ficar e do namoro. Há ainda o artigo científico de Justo (2005), que traz questões oriundas da Psicologia sobre o ficar, e a dissertação de Diógenes (2007) sobre o ficar entre adultos de Fortaleza.

Assim como no pegar, também no ficar o beijo é central (Almeida, 2006). Para Rieth (2001), que desenvolveu uma pesquisa de doutorado em Pelotas, no ficar há um envolvimento afetivo sem compromisso e por isso ele se torna uma maneira de conhecer pessoas diferentes. No mesmo sentido é o trabalho de Giongo (1998), para quem essa ausência de compromisso também faz com que a fidelidade não seja um requisito. Esse descomprometimento e essa efemeridade do ficar são considerados por Clair (2008) como um divertimento, expresso na categoria "fun" ".

Heilborn et al (2006, p. 165) demonstram em sua pesquisa a difusão dessa prática, já que 76\% das mulheres e 90\% dos homens declararam já ter tido a experiência de ficar, sendo que, dentre os entrevistados de Porto Alegre, os números eram ainda mais elevados: 88\% das mulheres e $94 \%$ dos homens revelaram já ter ficado. Nesse trabalho, o ficar é descrito como uma “experiência, em geral não sexualizada”, que "constitui o primeiro elemento de familiarização com a vida amorosa para os indivíduos dos dois sexos". Bozon e Heilborn (1996) salientam, além disso, que o ficar geralmente ocorre num lugar público.

Nessa análise do ficar, é preciso atentar para as diferenças de gênero. Elas estão presentes tanto no que diz respeito ao número de pessoas com que se fica quanto no que se refere ao ato de tomar a iniciativa. Clair (2008) assevera que, no caso das meninas, o "fun” possui limites, o que é também corroborado por Abramovay et al (2004), que alertam para o valor positivo

\footnotetext{
2 Diversão, em inglês.
} 
que é atribuído aos meninos que possuem uma variação de parceiras, enquanto que para as meninas na mesma situação pode gerar a atribuição de um valor negativo.

Por fim, um último elemento a respeito do ficar, também conexo a essa ideia de conhecer pessoas diferentes, é relevante aqui. Trata-se da ocorrência de práticas não-heterossexuais entre os jovens. Piloni (2010), em seu trabalho de conclusão de curso sobre jovens alternativos em Florianópolis, analisa festas nas quais os universitários ficam com pessoas do mesmo sexo. Aqui, além da ideia da diversão, estaria presente também a noção de liberação.

\subsection{Namoro}

Em diversos dos estudos citados, a prática do ficar aparece de forma contrastante à do namoro. Por esse motivo, a questão da demarcação de fronteiras entre uma prática e outra é algo constante. A dificuldade enfrentada pelos jovens para definir seu próprio status de relacionamento (se se trata de ficar ou namorar) é algo descrito tanto por Rieth (2001) quanto por Giongo (1998). E isso ocorreria principalmente porque o namoro, segundo Oliveira et al (2007), em geral decorre da continuidade e repetição do ficar com a mesma pessoa.

Diferentemente do ficar, a relação de namoro é publicizada para família e amigos, além da maior intensidade de sentimento dos envolvidos (Rieth, 2001; Oliveira et al, 2007; Leal, 2003). Além disso, no namoro há um elo mais forte entre os jovens do que no ficar, estabelecendo-se uma relação afetiva caracterizada pelo compromisso e pela durabilidade (Jesus, 2005). O namoro é tido como uma relação séria, na qual a fidelidade seria uma exigência (Rieth, 2001).

Por fim, outro ponto importante no que se refere ao namoro juvenil é a manutenção de relações sexuais. Embora não obrigatórias, a sua ocorrência se dá com frequência nessa prática (Heilborn et al, 2006), motivo pelo qual alguns jovens a compreendem como inclusive inevitável (Rieth, 2001). 
Pegar, ficar e namoro aparecem na literatura estudada como práticas e manifestações da sexualidade na juventude. Seriam, dessa maneira, formas de iniciação sexual e componentes da transição entre a vida afetiva juvenil e adulta. Nesse sentido, sua diferenciação é demarcada, mesmo que as fronteiras entre o pegar e o ficar sejam mais tênues, e que sobre a prática do pegar não existam muitos registros. No entanto, se no meio científico o pegar não é muito difundido, é a partir das falas dos próprios jovens que é possível apreender o seu sentido, diferenciando-o da prática de ficar, o que será feito a seguir.

\section{DIFERENÇAS E SEMELHANÇAS ENTRE AS NOÇÕES DE PEGARE FICAR}

As práticas do pegar, do ficar e do namoro encontram-se, de acordo com Oliveira et al (2007, p. 500), num "continuum que vai da liberdade absoluta à responsabilidade formalizada”. O pegar estaria num dos extremos, o da liberdade absoluta, enquanto que o namoro encarnaria a responsabilidade formalizada. Para os jovens da pesquisa de Oliveira et al (2007), no pegar há instantaneidade, ausência de compromisso e de repetição, bem como uma predominância no interesse físico, o que em geral resulta em beijos e não em relação sexual. O beijo, segundo Almeida (2006), ocupa um papel central nessas relações tão efêmeras.

Nas entrevistas realizadas sobre esse tema com os estudantes do Colégio Rose Marie Muraro, foi mencionada por praticamente todos os jovens a existência de diferenças entre pegar e ficar. Para Thaíse (16 anos), pegar e ficar consistem apenas de termos diferentes para designar a mesma prática, sendo que o termo pegar seria mais utilizado por meninos. Assim, tanto pegar quanto ficar envolveriam beijos e carícias a título de experimentação, sem qualquer tipo de compromisso com o outro que implicasse a continuidade da relação ou mesmo a repetição da prática em outro momento. Já para Laura (17 anos) em ambos os casos se trata da "mesma bobagem". A jovem 
criticou essa necessidade que alguns jovens têm de pegar todo mundo ou ficar com todo mundo.

Para os demais jovens que participaram das entrevistas, trata-se de práticas diferentes. Sofia (17 anos) fala das diferenças entre as práticas de pegar e ficar, descrevendo a sua ocorrência em uma festa. Para ela, pegar alguém é beijar e "sair fora”, ou seja, nunca mais olhar para a cara da pessoa; "pegar é só dá um peguinha bem rapidinho e era só isso".

Embora trate apenas do ficar, Almeida (2006, p. 150) esclarece-nos muito bem o papel que o beijo ocupa nessas relações tão efêmeras: "nos regimes que compõem as novas semióticas afetivas em torno do 'ficar', o beijo assume a condição de performance, de intransitividade, fisicalidade, arma corporal, descarga rápida da emoção. Princípio e fim. Ubiquidade do ato".

Eduardo (16 anos) fala ainda de uma questão corporal envolvendo o pegar, fato que também é evidenciado por Ana Carolina (16 anos). Logo, o pegar não incluiria apenas o beijo: "pegar é pegar... tem todo o jogo e vai... e... que é um lance mais quente”.

O jovem também afirma que para pegar é preciso ter pegada e que o pegar envolve agarramentos, ou seja, carícias mais íntimas, que não estariam tão presentes no ficar. A pegada consiste, portanto, num atributo do indivíduo. Ela não parece ser algo que possa ser adquirido, ou seja: ou tem pegada ou não tem.

José (16 anos) define o pegar como "aquela coisa só de uma tarde assim, uma coisa pouca assim, sabe. Só uma coisa momentânea”. A efemeridade dessa prática também é descrita por Ana Carolina (16 anos): "parece que pegar é aquela coisa mais do momento, de 'ah, tô a fim de pegar, peguei e deu'. Pegar e largar. É uma coisa mais, sei lá, desapego total assim. ${ }^{3}[\ldots]$ Pegar até sugere objeto, uma coisa mais corpo, uma coisa mais de contato.” Para ela, quando se fica com alguém em uma festa, a denominação utilizada deve ser o pegar: "eu acho que numa festa tu vai ter pegado a pessoa... não vai

3 Esse desapego é descrito em várias comunidades do Orkut, cujo título faz um trocadilho com as palavras pegar e apegar. É o caso de "Eu pego... mas não me apego", comunidade destinada "a todos aqueles que gostam de uma boa aventura sem qualquer compromisso". 
ter ficado”. Essa efemeridade também está presente no esclarecimento que Laura (17 anos) presta em sua entrevista: para a jovem, o termo pegar nunca é usado no presente. Logo, os jovens sempre falariam eu peguei.

O pegar envolve, ainda, além do beijo sem qualquer compromisso, do elemento corporal (a pegada) e do desapego, um desejo de estar com diversas pessoas. Para Natália, o pegar é “tipo 'ah, vou pegar todos hoje””. A prática de ficar sem compromisso ou de ficar com várias pessoas também é vista como forma de diversão e, por isso, é frequentemente exemplificada pelos jovens como algo que ocorre em uma festa. Ana Clara (17 anos) fala da prática de pegar como sendo "aquela coisa assim mais na diversão, sabe, quando tu tá numa festa 'ah, vou pegar' assim, meio sem compromisso, [...] nem tá preocupado com o que vai acontecer depois assim, ou com o sentimento".

Diante do que foi descrito por esses jovens, a prática do pegar parece se encaixar muito bem no modelo de amor líquido. Se as experiências amorosas constituem-se de "episódios intensos, curtos e impactantes" (Bauman, 2004, p. 20), o que poderia ser mais intenso, curto e impactante do que o pegar? Além disso, se o amor contemporâneo é visto como um desejo a ser saciado, também isso se aplica ao pegar.

A prática do pegar também pode ser associada à "relação de bolso" descrita por Bauman (2004). Isso porque o pegar encarna a instantaneidade e a disponibilidade presentes nesse tipo de relação. Não há compartilhamento, não há entrega e não há trocas. Não há paixão, sendo apenas necessário estar a fim, o que levaria a dar uns pega. A conveniência que Bauman (2004) diz estar presente nesse tipo de relação é personificada pela diversão descrita pelos jovens pesquisados. Pegar é, acima de tudo, divertir-se, curtir, aproveitar, sem envolvimento emocional e afetivo.

Para a grande maioria dos jovens participantes da pesquisa, portanto, há diferenças significativas entre pegar e ficar. Na prática do pegar, a noção de desapego assume extrema importância, pois aquilo que se pega com facilidade também se larga. $\mathrm{O}$ ato de pegar também é fortemente associado pelos interlocutores às festas realizadas em locais públicos, como em danceterias, nas quais a quantidade de pessoas desconhecidas geralmente supera a de 
conhecidas. É na festa que se pega, que é possível exercitar essa prática na qual as palavras (saber o nome do outro e conversar com ele) não se fazem necessárias.

Essa instantaneidade também permite que, numa mesma situação - a da festa, por exemplo - eles peguem várias pessoas, contabilizando, inclusive, recordes que são compartilhados posteriormente com os amigos. Pedro (17 anos) afirma que “pegar é tipo 'quantas tu pegou?' Peguei três, peguei dez”. Extremamente associada à diversão e à ausência de compromisso, a prática do pegar caracteriza também pela sua não continuidade, ou seja, pela não repetição: não se pega várias vezes a mesma pessoa. Quando se trata da mesma pessoa, aquela que o jovem já conhece, a relação adquire um outro status: o de ficar. Pedro (17 anos) informa que "ficar é mais tipo tá ficando" e que se fica com alguém que já se pegou antes.

No que tange à instantaneidade, é interessante notar que os jovens, quando pegam a mesma pessoa a festa inteira, ou seja, quando permanecem durante toda a festa com a mesma pessoa, afirmam que casaram na festa. Esse termo foi utilizado tanto por Pedro (17 anos), quanto por Natasha (16 anos). Pedro (17 anos) esclarece que prefere ficar com meninas que ele já conhece (por isso utiliza o termo ficar, e não pegar), mas que não necessariamente casa com elas nas festas. Ele esclarece que nesses casos conversa um pouco com a menina, fica com ela, mas depois vai "dar uma volta" com os amigos e, num outro momento, eles podem se encontrar novamente na mesma festa. Logo, o termo casar, utilizado nas festas, pode ser aplicado tanto a conhecidos quanto a desconhecidos, mas se dá com quem se fica e não com quem se pega, já que se trata de uma relação mais duradoura. A ideia de curtir a festa com os amigos é apontada tanto por Pedro (17 anos) quanto por Natasha (16 anos) como um empecilho a esse casar. Natasha (16 anos) inclusive afirma que, quando saía com as amigas para curtir, elas faziam uma espécie de pacto entre elas, o de que nenhuma delas casaria na festa.

As características do amor líquido elencadas também estão presentes na prática do ficar, embora a instantaneidade e o desapego não sejam tão extremos. Também a duração da relação pode se estender, não sendo restrito apenas a alguns pega, a um ou alguns beijos e a carícias de apenas alguns 
minutos. Rieth (2001) define o ficar como uma "forma descomprometida de envolvimento afetivo, ou como uma forma comum e prática de conhecer outras pessoas" (2002, p. 90).

Esse descomprometimento que é associado frequentemente pelos jovens à diversão está presente na prática. Ao tratar da experiência amorosa entre jovens da periferia de Paris, Clair (2008) apresenta a categoria "fun", ou seja, diversão. Para a autora, as relações de diversão são necessariamente efêmeras, já que a diversão só seria possível quando se escapa de relações longas e da gestão e dos aborrecimentos que estão presentes em relações mais sérias.

Como já foi afirmado anteriormente, há muito mais referências de pesquisas sobre o ficar. Para Bozon e Heilborn (1996), o ficar contrasta fortemente com o namoro e consiste num relacionamento que ocorre geralmente num lugar público, envolvendo normalmente beijos e carícias, sem que isso implique comprometimento entre os envolvidos. Outra característica importante do ficar seria a de prescindir de contato verbal. Os jovens de Aracaju associam ficar a "beijar sem compromisso", "relacionamento momentâneo" e "conhecer alguém" (Jesus, 2005, p. 70). A caracterização de Justo (2005, p. 71) vai no mesmo sentido:

Embora a palavra "ficar" tenha o sentido genérico de parada e permanência, sugerindo uma certa fixação em algum lugar, seu uso pelos adolescentes, ao contrário, designa um relacionamento episódico e ocasional, na maioria das vezes com a duração de apenas algumas horas ao longo de uma noitada de festa e diversão. A prática mais comum envolve beijos, abraços e carinhos. Outra característica importante é que o "ficar" não implica compromissos futuros e é visto como um relacionamento passageiro, fortuito, superficial, sem maiores consequências ou envolvimentos profundos. 
Em relação à comparação com o namoro, é possível afirmar que o ficar não possui nem as formalidades e nem a visibilidade social presentes no primeiro tipo de relacionamento, encontrando-se "em uma região definitória mediana entre a liberdade e a responsabilidade" (Oliveira et al, 2007, p. 500-501). Para Giongo (1998), o compromisso e a fidelidade não estão presentes no ficar mesmo quando se está ficando, ou seja, ainda que esse ficar não esteja restrito à troca de alguns beijos em uma festa.

José (16 anos) fala na divisão existente entre pegar e ficar em categorias. Ele afirma que ficar seria "uma coisa que vai dar... que pode desencadear um namoro". Ficar possui, segundo o jovem, um compromisso que não está presente na prática de pegar. Ele ainda esclarece: "se tu conhece a pessoa, tu já tem tipo uma intimidade com a pessoa, e na festa tu pegou ela... eu considero ficar”, fato que é também corroborado por Natália, para quem o ficar envolve alguém que já se conhece anteriormente. Pedro (17 anos) diz que, nesse caso, não se utiliza o termo pegar porque ele é "meio chulo". Esse maior comprometimento existente na prática do ficar também aparece na fala de Laura (17 anos).

Para Ana Clara (17 anos), além do conhecimento prévio da pessoa, há uma continuidade na prática de ficar que não está presente na de pegar:

acho que é mais aquela coisa que já vinha de antes, já tinha meio que combinado... meio que conversado por MSN, alguma coisa assim. Daí tu fica com a pessoa, daí no outro dia tu vai lá, fica com ela de novo assim. É uma coisa mais contínua, sabe... que vai além do que só uma noite.

As falas dos jovens pesquisados contrariam, portanto, as noções de "desinvestimento" e de ausência de escolha no ficar, descritas por Giongo (1998, p. 146-147). Para a psicóloga, além da efemeridade, da ausência de compromisso e da necessidade de fidelidade do ficar, haveria também um “desinvestimento" na pessoa com quem os jovens ficam: "o outro é tratado como objeto descartável, como 'coisa', passível de ser escolhida entre outras, ou para ser 'largada fora”'. Ela também fala que não haveria uma escolha em 
relação à pessoa com quem os jovens ficam e que ficar com qualquer pessoa consiste numa possibilidade: "não importa com quem se fique, desde que se possa ficar".

Essa combinação prévia, esse conhecimento anterior da pessoa com quem os jovens ficam revelam um investimento e uma escolha prévia. Portanto, a fala de Giongo, a partir do que é dito pelos jovens, poderia ser aplicada à prática do pegar, mas não à do ficar. Natália diz que o termo ficar é mais utilizado por ela "quando é gente conhecida assim, quando... não que tu vá ficar várias vezes, sabe? Mas é uma pessoa, é mais próxima de ti”. A jovem também afirma que o ficar não está ligado à consideração que se tem em relação à pessoa com que se fica, mas com o conhecimento prévio: "por ela ser uma pessoa conhecida daí tu sabe mais ou menos o que tu vai fazer, sabe? Tu não vai, não é uma coisa... sei lá, totalmente desprogramada”.

No entanto, é preciso corroborar as palavras de Giongo (1998, p. 147) quando diz que "o ficar é uma relação que não possui início, meio e fim", embora discorde de que ele "não permite vínculo, ou troca", já que isso também seria mais aplicável ao pegar, em virtude do maior envolvimento presente no ficar. Além disso, Giongo (1998, p. 148) tem razão quando afirma que "gostar, no ficar, não é necessário". Basta, como foi dito no início do capítulo, estar a fim. No entanto, o ficar também está associado ao que se sente em relação à pessoa com quem se fica. Para Ana Carolina (16 anos), há uma diferença de intensidade entre o pegar e o ficar: "esse negócio de pegar e ficar pode ser considerado muito como intensidade. Talvez pegar tenha uma intensidade menor, do que se diz... de sentimento, de sentir [...] intensidade menor, e o ficar é uma intensidade maior. Isso só sentindo pra tu saber a diferença".

Sofia (17 anos) diz que o ficar tem uma duração maior, já que se estende por mais tempo; geralmente durante toda a festa. Ainda que exista um compromisso maior envolvendo a prática do ficar, Sofia alerta-me de que tanto pegar quanto ficar podem estar restritos a apenas uma festa. Ou seja, ficar é apenas ficar naquele momento. Se o relacionamento se estende, podese dizer que o casal está ficando, que pode evoluir para o ficar sério, quando já pode existir um compromisso de fidelidade, e para um namoro, desde que 
exista um acordo entre o casal de que eles estão namorando, ou desde que exista um pedido de namoro.

É interessante notar a diferença existente entre o descrito por Sofia (17 anos) sobre o início do namoro e a análise de Azevedo (1986, p. 9) sobre o namoro no Brasil de meados do século XX. Segundo o antropólogo,

o namoro costumava passar por duas ou três fases [...]: a da troca dos primeiros e furtivos sinais de interesse recíproco e da exploração das possibilidades de aproximação e de comunicação interpessoal direta e próxima, a da associação deliberada ou namoro em sentido exato e a do compromisso preliminar ao noivado formal.

Embora os jovens pesquisados também façam uma associação entre as práticas de pegar, ficar, namorar e casar, colocando-as, às vezes, como diferentes etapas de uma relação afetiva, pode-se dizer que essa "troca dos primeiros e furtivos sinais de interesse recíproco" e "a exploração das possibilidades de aproximação e de comunicação interpessoal direta e próxima" sequer são mencionadas como uma prática afetiva em si. Elas são tidas, na realidade, como demonstrações do estar a fim e como formas de aproximação. Além disso, a duração dessa etapa prévia ao pegar e ao ficar é bastante restrita e muitas vezes ela pode nem ocorrer.

É preciso salientar ainda que o pedido de namoro ao qual Sofia (17 anos) se referiu na entrevista provavelmente muito pouco se assemelha ao “compromisso" do qual fala Azevedo (1986). Em primeiro lugar, porque quem pede em namoro não é necessariamente o menino e porque esse pedido também está muito mais próximo do acordo sobre o namoro que a mesma jovem descreve. O início do namoro se dá apenas após a etapa do ficar e a etapa do ficar sério, o que significa que os sujeitos envolvidos já se conhecem e, no mínimo, já trocaram diversas vezes beijos e carícias, ou mesmo mantiveram relações sexuais.

Para ficar ou pegar, segundo Sofia (17 anos), é preciso que ocorra beijo de língua: 
o ficar, por exemplo, tu pode transar com um guri que tu não ficou com ele ... entendeu? Mas ficar ... é, tem que beijar de língua. Não adianta nem selinho. Tipo, tu pode dar pro guri que tu não ficou com ele. Ao meu ver é isso, tipo ... se tu dá um selinho tu não ficou, foi só um selinho. Se tu deu, tu não ficou, tu só deu.

Ana Carolina (16 anos) diz que "o ficar, envolve talvez uma vontade maior das duas pessoas, não é só... aquela coisa mais corporal, já pegar. [...] o ficar eu acho que é menos... não tanto quanto só corporal”. Para a jovem, o ficar seria um segundo momento do relacionamento, que viria depois do pegar: "eu acho que o ficar é... pode ser evolução, tipo tu pegou a pessoa e depois tu pode vir a ficar com ela. Eu acho que... o segundo passo". Também para Ana Clara (17 anos) o pegar pode se transformar num ficar: "pode acontecer claro, a gente pode se apegar àquela pessoa, curtir, ter ficado e tal, acho que pode acontecer, normal”.

Embora também centralizado na figura do beijo e ainda caracterizado pela instantaneidade, o ficar apresenta alguns aspectos diferenciais em relação ao pegar. Em primeiro lugar, para ficar, não é preciso antes pegar. O ficar é caracterizado pelos jovens principalmente por três características: o conhecimento prévio da pessoa com quem se fica, um sentimento mais intenso envolvido (ainda que o estar a fim seja suficiente para ficar, o desapego não está tão presente aqui) e uma maior duração em relação ao pegar, ainda que o ficar também possa durar apenas uma festa. Nesse caso, quem pega o faz apenas por um momento e quem fica o faz por toda ou quase toda a festa. Essa maior duração do ficar pode gerar inclusive outras duas situações, a de estar ficando e a de ficar sério, quando pode estar presente inclusive um compromisso de fidelidade, à semelhança da relação de namoro. Nota-se, portanto, que pegar e ficar podem estar situados no extremo da linha de evolução dos relacionamentos afetivos, na qual estariam ainda presentes o namoro e a conjugalidade. 
Se "compreender a juventude atual é desvendar o mundo de hoje" (Novaes, 2007, p. 253), também as práticas afetivas desses jovens auxiliam na compreensão da sexualidade, do amor e da conjugalidade contemporâneos. Afinal, os jovens pegam e não se apegam ou são para casar? Acredito que eles pegam e não se apegam, pegam e se apegam, ficam e namoram. Se, para a geração dos anos 1990, oficar se apresentou como uma prática revolucionária, a noção de pegar demonstra que o ficar pode adquirir dimensões ainda mais fluidas e instáveis. Pegar é pegar e largar, é não ter apego. Os jovens pegam sobretudo desconhecidos em festas, sem perguntar o nome. É o beijo que sela essa prática, acrescido ou não de outras carícias. No entanto, não se pode pegar durante muito tempo e o ideal é pegar mais de uma pessoa na mesma festa, às vezes até algumas pessoas ou mesmo dezenas delas.

Já o ficar seria para o pegar o que o namoro já foi para oficar. Ficar envolve um conhecimento prévio do outro e também um sentimento: o de estar a fim. Fica-se com quem já se conhece (colega, amigo etc.), fica-se com quem se tem uma certa consideração, fica-se com a pessoa de quem se está a fim. Ficar seria, portanto, pegar e se apegar. Não há tanta fluidez, não há tanta descartabilidade, não há tanto desapego quanto no pegar.

\section{REFERÊNCIAS}

ABRAMO, Helena W. Considerações sobre a tematização social da juventude no Brasil. In: FÁVERO, Osmar et al. (Orgs.). Juventude e contemporaneidade. Brasília: UNESCO, MEC, ANPEd, 2007, p. 73-92.

ABRAMOVAY, Miriam et al. Juventude e sexualidade. Brasília: UNESCO, 2004.

ALMEIDA, Maria Isabel Mendes de. "Zoar" e "ficar": novos termos da sociabilidade jovem. In: ___ EUGENIO, Fernanda (Orgs.). Culturas juvenis: novos mapas do afeto. Rio de Janeiro: Jorge Zahar, 2006, p. 139-157.

ARIÈS, Philippe. História social da criança e da família. 2.ed. Rio de Janeiro: LTC, 1981.

AZEVEDO, Thales de. As regras do namoro à antiga. São Paulo: Ática, 1986. 
BAUMAN, Zygmunt. Amor líquido: sobre a fragilidade das relações humanas. Rio de Janeiro: Jorge Zahar, 2004.

BOZON, Michel; HEILBORN, Maria Luiza. Les caresses et les mots. Terrain: revue d'ethnologie de l'Europe, Paris, n. 27, p. 2-25, set. 1996. Disponível em: <http://terrain.revues.org/index3382.html>. Acesso em: 10 dez. 2009.

CARDOSO, Irene. A geração dos anos de 1960: o peso de uma herança. Tempo Social, São Paulo, v. 17, n. 2, p. 93-107, nov. 2005.

CLAIR, Isabelle. Les jeunes et l'amour dans les cités. Paris: Armand Colin, 2008.

DIÓGENES, Kátia Muniz. O "ficar": um estudo fenomenológico sobre os novos vínculos afetivos entre mulheres e homens adultos na cidade de Fortaleza. 156f. Dissertação (Mestrado em Psicologia), Universidade de Fortaleza, Fortaleza, CE, 2007.

FORACCHI, Marialice Mencarini. O estudante e a transformação da sociedade brasileira. São Paulo: Cia. Editora Nacional, 1965.

FOUCAULT, Michel. História da sexualidade. v.1. Rio de Janeiro: Graal, 1988.

GALLAND, Olivier. Sociologie de la jeunesse. Paris: Armand Collin, 1997.

GIDDENS, Anthony. A transformação da intimidade: sexualidade, amor e erotismo nas sociedades modernas. São Paulo: Unesp, 1993.

GIONGO, Ana Laura. O "ficar" e sua função na adolescência: um estudo em uma escola de classe média-alta de Porto Alegre. Universidade Federal do Rio Grande do Sul, Instituto de Psicologia, Pós-graduação em Psicologia do Desenvolvimento. 1998. $194 f$.

GIROUX, Henry. O filme Kids e a política de demonização da juventude. Educação e Realidade, Porto Alegre, v. 21, n. 1, p. 123-136, jan./jun. 1996.

GROPPO, Luís Antonio. Juventude: ensaios sobre sociologia e história das juventudes modernas. Rio de Janeiro: DIFEL, 2000.

GUARESCHI, Neuza. O "ficar": novas perspectivas nas relações de gênero de meninas e meninos. Psico, Porto Alegre, n. 30, v. 2, p. 81-94, jul./dez. 1999.

HEILBORN, Maria Luiza et al (Orgs.). O aprendizado da sexualidade: reprodução e trajetórias sociais de jovens brasileiros. Rio de Janeiro: Garamond; Fiocruz, 2006.

JESUS, Jardel Oliveira de. Ficar ou namorar: um dilema juvenil. Revista de Psicologia da Vetor Editora, São Paulo, v. 6, n. 1, p. 67-73, jan./jun. 2005.

JUSTO, José Sterza. O "ficar" na adolescência e paradigmas de relacionamento amoroso da contemporaneidade. Revista do Departamento de Psicologia - UFF, v. 17, n. 1, p. 61-77, jan./jun. 2005. 
LAGO, Mara Coelho de Souza. Gênero e gerações na Ilha de Santa Catarina. In: PEDRO, Joana

Maria; GROSSI, Miriam Pillar (orgs.). Masculino, feminino, plural: gênero na interdisciplinaridade. Florianópolis: Mulheres, 2006, p. 259-271.

LOURO, Guacira Lopes. Gênero, sexualidade e educação: uma perspectiva pós-estruturalista. Petrópolis: Vozes, 1997.

. O cinema como pedagogia. In: LOPES, Eliana, MENDES, Luciano, GREIVE, Cynthia (Orgs.). 500 anos de educação no Brasil. Belo Horizonte: Autêntica, 2000, p. 423-446.

MAGNANI, José Guilherme Cantor. Os circuitos dos jovens urbanos. Tempo social, São Paulo, v. 17, n. 2, p. 173-205, nov. 2005.

MARCUS, G. E. Ethnography in/of the world system: the emergence of multi-sited ethnography. Annual Review Anthropology, Palo Alto, v. 24, p. 95-117, 1995.

MEAD, Margaret. Adolescencia y cultura en Samoa. Buenos Aires: Paidós, 1961.

NOVAES, Regina. Políticas de juventude no Brasil: continuidades e rupturas. In: FÁVERO, Osmar et al. (Orgs.). Juventude e contemporaneidade. Brasília: UNESCO, MEC, ANPEd, 2007, p. 253-281.

OLIVEIRA, Denize Cristina de et al. "Pegar", "ficar" e "namorar": representações sociais de relacionamentos entre adolescentes. Revista Brasileira de Enfermagem, Brasília, v. 60, n. 5, p. 497 502, set./out. 2007.

PERALVA, Angelina T. O jovem como modelo cultural. In: FÁVERO, Osmar et al. (orgs.). Juventude e contemporaneidade. Brasília: UNESCO, MEC, ANPEd, 2007, p. 13-28.

PILONI, Nayara Uber. Jovens alternativos em Florianópolis: sexualidades, festas e estilos de vida. Florianópolis, 2010. 109f. Trabalho de Conclusão de Curso (Graduação em Ciências Sociais) - Curso de Ciências Sociais, Universidade Federal de Santa Catarina, Florianópolis, SC, 2010.

REGUILLO, Rossana. Las culturas juveniles: un campo de estudio; breve agenda para la discusión. Revista Brasileira de Educação, Rio de Janeiro, p. 103-118, maio/ago. 2003.

RIETH, Flávia. A iniciação sexual na juventude de mulheres e homens. Horizontes Antropológicos, Porto Alegre, ano 8, n. 17, p. 77-91, jun. 2002.

Sexo, amor e moralidade: a iniciação na juventude de mulheres e homens, Pelotas (RS). 2001. 311f. Tese (Doutorado em Antropologia Social) - Programa de Pós-graduação em Antropologia Social, Universidade Federal do Rio Grande do Sul, Porto Alegre, RS, 2001.

RUBIN, Gayle. Pensando o sexo: notas para uma teoria radical das políticas da sexualidade. 2010. Disponível em: < http://www.miriamgrossi.cfh.prof.ufsc.br/pdf/gaylerubin.pdf > . Acesso em: 15 out. 2011. 
SCHUCH, Patrice. Carícias, olhares e palavras: uma etnografia sobre o "ficar" entre jovens universitários de Porto Alegre/RS. 1998. 213f. Dissertação (Mestrado em Antropologia Social) Programa de Pós-graduação em Antropologia Social, Universidade Federal do Rio Grande do Sul, Porto Alegre, RS, 1998.

"Ficar" ou namorar: eis a questão: relações de gênero, afeto e corpo entre jovens universitários de Porto Alegre. Revista Brasileira de Sociologia da Emoção, João Pessoa, v. 1, n. 3, p. 282-302, dez. 2002.

VANCE, Carole S. A antropologia redescobre a sexualidade: um comentário teórico. Physis: Revista de Saúde Coletiva. Rio de Janeiro, v. 5, n. 1, p. 7-31, 1995.

WEEKS, Jeffrey. O corpo e a sexualidade. In: LOURO, Guacira Lopes (org.). O corpo educado: pedagogias da sexualidade. 2.ed. Belo Horizonte: Autêntica, 2001, p. 47-64.

WEINGARTNER, Carmen Lisboa et al. O ficar e o namorar vistos pelos adolescentes. Psicologia: reflexão e crítica, Porto Alegre, n. 8, v. 1, p. 181-203, jan./jul. 1995.

WELLER, Wivian. A presença feminina nas (sub)culturas juvenis: a arte de se tornar visível. Estudos Feministas, Florianópolis, v. 13, n. 1, p. 107-126, jan.-abr. 2005. 


\section{EDUCAÇÃO PARA A SEXUALIDADE, EQUIDADE DE GÊNERO E DIVERSIDADE SEXUAL: APONTAMENTOS PARA FORMAÇÃO DE PROFESSORES(AS) DA EDUCAÇÃO BÁSICA}

Alessandra Maria Bohm

\section{PALAVRAS INICIAIS}

O presente texto tem por objetivo contribuir para o desenvolvimento de habilidades e competências para que professores(as) da educação básica possam atuar em sala de aula, inserindo nos currículos escolares as temáticas de educação para sexualidade, relações de gênero e diversidade sexual. As instituições escolares são fértil terreno para exercitar a cidadania e a Educação em Direitos Humanos, muito embora se reconheça que no Brasil contemporâneo ainda persistam inúmeras situações ilustrativas da violação dos mesmos. Seguindo o argumento de Melissa Pimenta (2015), a violação dos direitos implica a "desumanização e coisificação do outro", que, embora seja também um ser humano, nunca é visto como tal.

Saber ser e saber conviver com as diversidades e as diferenças são os grandes desafios de educadores que apostam na importância da prática educativa enquanto instrumento para a formação das futuras gerações. 
Gerações essas que compreendam o significado de cidadania e direitos humanos para além de um entendimento imediato, que não contempla, de fato, seus significados.

O texto propõe problematizar a importância da Educação em Direitos Humanos e Cidadania a partir da educação para as relações de gênero, sexualidade e diversidade sexual. Tais iniciativas se constituem como um esboço que aponta algumas das temáticas necessárias e que possibilitam rabiscar rotas provisórias para o desenvolvimento do texto.

A construção de um currículo que valorize o indivíduo e o coletivo deve articular e problematizar a representação de diferentes marcadores identitários, entre eles raça/etnia, gênero, classe social, sexualidade, geracionalidade e diferenças físicas e cognitivas, contribuindo assim para o respeito e valorização da multiplicidade de sujeitos que compõem nossa sociedade. Através da implementação de projetos didáticos, se faz possível o desenvolvimento de práticas educativas significativas e que objetivam uma formação integral do sujeito, vinculando a aprendizagem dos conhecimentos escolares à capacitação das habilidades afetivas e sociais. Para tal, a capacitação continuada de professores é um dos elementos centrais para que sejam possíveis práticas de Educação para os Direitos Humanos e para o exercício da cidadania.

Antes de qualquer coisa, é necessário sensibilizar os docentes para que estes identifiquem a necessidade de comprometimento com a Educação em Direitos Humanos e Cidadania, pois só assim será possível a elaboração de um trabalho educativo que contemple tais temáticas. Admite-se que, como nas discussões de raça e etnia (Rocha, 2009), as temáticas indicadas neste texto, na maioria das vezes, passam pela fase da invisibilidade e da negação (ilustrativas em frases como "isso não é competência da escola, além disso, esse tipo de problema não existe aqui”), para chegar à necessária etapa do reconhecimento e do avanço. 


\section{A IMPORTÂNCIA DAS INSTITUIÇÕES ESCOLARES NA CONSTRUÇÃO DE APRENDIZAGENS ATITUDINAIS}

Os(as) pesquisadores educacionais estão apenas começando a compreender que a escolarização produz não apenas formas de conhecimento e relações particulares de desigualdade, ao longo de divisores de raça e de gênero, mas, imediatamente, produz e organiza, de forma coincidente, as identidades raciais, culturais e generificadas dos(as) estudantes.

O que essa coisa chamada amor? (Britzman, 1996, p. 72).

A partir da assertiva de que as instituições educacionais ocupam lugar central na formação de valores e de construção de referenciais de inter-relações humanas é possível argumentar que é fundamental a busca intermitente de valorização e qualificação dos profissionais que ali atuam, além da instituição de currículos e práticas educativas que visem a uma educação para além dos conhecimentos disciplinares. Nesse sentido:

A capacidade de uma pessoa para se relacionar depende das experiências que vive, e as instituições educacionais são um dos lugares preferenciais, nesta época, para estabelecer vínculos e relações que condicionam e definem as próprias concepções pessoais sobre si mesmo e sobre os demais (Zabala, 1998, p. 28).

Valores éticos e que desenvolvam valores de justiça e cultura da paz devem abarcar todas as práticas educacionais através de debates e discussões, vivências que instiguem a importância da valorização dos direitos humanos desde a educação infantil. Solidariedade, empatia, apreço às diferenças, respeito a si e aos outros são conhecimentos atitudinais que merecem destaque e que, se inseridos nos diferentes níveis de ensino, possibilitam a 
construção de futuras gerações mais preocupadas com a coletividade e com a formação de uma sociedade mais justa e solidária e menos desigual.

Em se tratando da Educação em Direitos Humanos (EDH) esta compreende todo o processo educativo, indo além da aprendizagem cognitiva, considerando o aspecto social e emocional do desenvolvimento humano, de forma que as dimensões da ética, da justiça, dos direitos humanos como um todo devem estar presentes neste processo. Portanto, a educação consiste em um instrumento indispensável para o fortalecimento da cidadania (Santos et al., 2010, p. 4).

Os currículos educacionais ocupam nesse cenário uma importância central que define os saberes e conhecimentos que serão ou não desenvolvidos e valorizados dentro de um determinado modelo de sociedade. É recorrente a seleção de conhecimentos conceituais e procedimentais que visam à transmissão de conteúdos fragmentados, pontuais e desconectados da realidade na qual os sujeitos estão inseridos. Dentro dessa lógica, a fragmentação de matérias escolares e a falta de interdisciplinaridade atuam como um modelo de educação tradicional, desconsiderando as necessidades cognitivas e intelectuais que constituem os seres humanos. Tais práticas dificultam o entendimento e a assimilação dos saberes, já que muitas vezes não existe um fio condutor que facilite a compreensão sequencial dos aprendizados. Da mesma forma, as disciplinas são organizadas de forma descontextualizada e em raras situações é possível acompanhar quais conhecimentos não foram construídos para serem retomados na etapa seguinte, o que sugere o estabelecimento de lacunas de construção de saberes que geralmente não atendem à demanda do aluno fora dos muros escolares.

O currículo é sempre o resultado de uma seleção: de um universo mais amplo de conhecimentos e saberes seleciona-se a parte que vai construir, precisamente o currículo. [...] na medida em que as teorias 
de currículo deduzem o tipo de conhecimento considerado importante justamente a partir de que descrições sobre o tipo de pessoa que elas consideram ideal. Qual é o tipo de ser humano desejável para um tipo de sociedade? (Silva, 2000, p. 15).

Cabe problematizar: dentro de uma hierarquia de seleção de saberes que são valorizados ou não nos currículos escolares, quais valorizam a construção de valores éticos e voltados à educação para os direitos humanos? Quais conhecimentos de ser e saber conviver estão imersos nas pautas curriculares? As aprendizagens desenvolvidas contemplam e valorizam a construção de uma sociedade mais humanitária, igualitária e solidária? Existem práticas educativas que ensinam sobre a educação para sexualidade, para a equidade entre os gêneros e para o respeito às diversidades sexuais?

Se admitirmos que a escola não apenas transmite conhecimentos, nem mesmo apenas os produz, mas que ela também fabrica sujeitos, produz identidades étnicas, de gênero, de classe; se reconhecermos que essas identidades estão sendo produzidas através de relações de desigualdade; se admitirmos que a escola está intrinsecamente comprometida com a manutenção de uma sociedade dividida e que faz isso cotidianamente, com nossa participação ou omissão; se acreditarmos que a prática escolar é historicamente contingente e que é uma prática política, isto é, que se transforma e pode ser subvertida; e, por fim, se não nos sentimos conformes com essas divisões sociais, então, certamente, encontrarmos justificativas não apenas para observar, mas especialmente, para tentar interferir na continuidade dessas desigualdades (Louro, 1997, p. 85).

Por meio de uma proposta de formação continuada de professores, é possível qualificar o processo de ensino-aprendizagem através da sensibilização e qualificação docente para que os(as) professores(as) estejam 
capacitados(as) a inserir tais temáticas enquanto elementos transversais na interação escolar. Trata-se ainda de uma proposta baseada em experiências em formação de professores(as) e revisão teórica norteada em referenciais teóricos e metodológicos voltados à educação para a sexualidade e igualdade de gênero.

\section{EDUCAÇÃO PARA A SEXUALIDADE: PRESSUPOSTOS PARA A FORMAÇÃO DE PROFESSORES(AS)}

Uma das premissas necessárias para o desenvolvimento da educação para a sexualidade na escola diz respeito à desconstrução de verdades absolutas e de paradigmas (hetero) normativos relativos à sexualidade e às relações de gênero e da compreensão do caráter sócio-histórico-cultural. Isso corrobora com a ideia de que a construção de saberes biológicos sobre o funcionamento corporal, as doenças sexualmente transmissíveis e os contraceptivos são apenas fragmentos da pluralidade de temáticas que envolvem a educação para a sexualidade.

Deborah Britzman (1996), ao problematizar as formas pelas quais a sexualidade é representada nas instituições escolares, constrói concepções disciplinadoras e hegemônicas e argumenta que é:

Precisamente um dos locais onde a heterossexualidade é normalizada. Quando chega a ser tratado, o conhecimento de sala de aula sobre sexualidade é tipicamente sinônimo de reprodução heterossexual, embora até mesmo esse conhecimento seja banalizado (Britzman, 1996, p.78).

Jimena Furlani (2003) atenta para a importância da construção de uma proposta continuada de educação para a sexualidade nos espaços escolares, argumentando que:

Quando falo em Educação sexual não me refiro a atividades pontuais e descontínuas. [...] Insisto que 
deve se caracterizar pela continuidade. Uma continuidade baseada em princípios claros de um processo permanente - porque o bombardeamento midiático de informações recebidas por crianças e jovens é permanente... porque as situações de exclusão social, decorrentes de sexismo e da homofobia, são constantes (Furlani, 2003, p. 68).

Em outra abordagem, as pedagogias feministas dão subsídio à educação da sexualidade na medida em que promovem a reflexão e rompem com as hierarquias hegemônicas que estão inseridas no cotidiano escolar:

Pensada como um novo modelo pedagógico construído para subverter a posição desigual e subordinada das mulheres no espaço escolar, a pedagogia feminista vai propor um conjunto de estratégias, procedimentos e disposições que devem romper com as relações hierárquicas presentes nas salas de aula tradicionais (Louro, 1997, p. 113).

Organizo a seguir as temáticas necessárias em seis subtítulos, ainda que outros tantos elementos derivados destas temáticas possam fazer parte da proposta:

\subsection{Desconstrução de Representações Sexistas em Busca da Equidade no Exercício dos Papéis de Gênero: Mídias}

Desconstruir representações sexistas como os papéis de gênero estereotipados (as brincadeiras, as tarefas domésticas, as profissões, etc.) contribui para promoção de relações igualitárias.

É importante questionar os padrões de beleza hegemônicos e estimular a construção de autoimagem positiva, além de problematizar a representação estética hegemônica apresentada por diferentes artefatos culturais e midiáticos (revistas, filmes, televisão, livros infantis, desenhos animados, etc.). Argumentar favoravelmente frente às diferenças (peso, raça/etnia, 
idade, aparência) e reconhecer que existem imposições de modelos de beleza que são cotidianamente apresentados pelos diferentes artefatos culturais são também essenciais para a desconstrução desses padrões. Valorizar a própria estética corporal para a construção da imagem positiva de si mesmo(a) e respeitar as diferenças físicas e estéticas das demais pessoas se inserem nesse mesmo contexto.

Sobre o papel da mídia e dos artefatos culturais:

Quanto aos contos e fábula que permearam nossa infância, sendo um dos recursos para elaborarmos nossa psique na representação do feminino/masculino, há algumas metáforas em comum: a mulher é sempre frágil, insegura e insuficiente, sempre à espera do herói travestido em príncipe, caçador, cavaleiro... portadores de instrumentos falocráticos (espadas, lanças, fuzis) e detentores de beijos mágicos, ressuscitadores (Teixeira; Alcântara, 2010, p. 15).

\subsection{Questões Biológicas, Conhecimento do Próprio Corpo E do(a) Outro(a), Exercício Saudável da Sexualidade, Prevenção de DSTS/ AIDS e Uso de Preservativos e Contraceptivos}

É importante conhecer o próprio corpo, o corpo do outro e desenvolver consciência corporal no que tange à questão biológica/orgânica: aparelhos sexuais e reprodutores, menstruação, gravidez etc. e debater sobre o exercício responsável da sexualidade, incluindo o conhecimento de preservativos e contraceptivos e a prevenção às DSTs, incluindo HIV/AIDS.

\subsection{Respeito às Diversidades Sexuais e de Gênero}

É fundamental o conhecimento e a construção de práticas de respeito às diversidades identitárias e sexuais através da problematização de noções preconceituosas e estereotipadas que muitas vezes fazem parte da dinâmica 
escolar. Silva (2004), ao argumentar sobre como os diferentes discursos escolares naturalizam e reiteram a heterossexualidade como o referencial dominante da sexualidade, diz que "[a]s identidades homossexuais são representadas como sujas, imorais, nojentas, aberrações, desviantes, ilegítimas, e em expressões simpáticas ou politicamente corretas como alternativas" (Silva, 2004, p. 89).

Capacitar professores(as) para que possam educar para a diversidade significa fornecer subsídios de apropriação e conhecimento sobre as tantas variações existentes das formas de vivências de afetividade e sexualidade. Portanto, conceituar e diferenciar as articulações e rupturas relativas aos conceitos de gênero, orientação sexual, sexo biológico e identidade de gênero é premissa básica para o reconhecimento de elementos relativos à expressão da sexualidade humana, possibilitando uma educação que exercite o convívio pacífico e respeitoso às multiplicidades identitárias de gênero e de orientações sexuais nos espaços escolares e na sociedade.

\subsection{Prevenção de Abuso e Exploração Sexual e Uso Responsável de Mídias Eletrônicas}

Abordar temáticas que envolvam a construção de uma cultura preventiva com relação ao reconhecimento e prevenção de violência de gênero, do abuso sexual e da exploração sexual é fundamental, além de argumentar sobre o uso responsável das mídias eletrônicas para a prevenção de crimes sexuais e fornecer informações para reconhecê-los e saber proteger a própria intimidade.

3.5 Incentivo à Criação de Projeto de Vida e ao Desenvolvimento de Subsídios para o Exercício Planejado de Possível Maternidade e/ou Paternidade

Um currículo preocupado com as formas pelas quais os(as) alunos(as) construirão e executarão o planejamento de vida deve incluir subsídios para discussões acerca da importância dos projetos de vida enquanto elementos 
que possibilitarão projetar um esboço de um mapa do caminho que deseja percorrer. Isso ajuda os(as) alunos(as) a exercitar a construção de um projeto para a própria vida, especialmente relativo aos aspectos afetivos e de constituição familiar.

\subsection{Reconhecimento e Valorização de Diferentes Configurações Familiares}

Compreender que existem diferentes configurações familiares, inclusive não heteronormativas, e argumentar para o respeito à diversidade são posturas essenciais para reconhecê-las e valorizá-las. As diferentes configurações incluem, por exemplo, casais homoafetivos que adotam crianças e adolescentes, tios e tias que criam os sobrinhos devido a uma reorganização na relação dos pais, mães que criam sozinhas seus filhos (sem a ajuda e o convívio do pai), filhos LGBTTs.

\section{CONSIDERAÇÕES FINAIS}

O caminho à educação da sexualidade, equidade de gênero e respeito às diversidades sexuais passa pela desconstrução de concepções que foram concebidas ao longo da trajetória pessoal de cada indivíduo, através do que foi ensinado pela família, escola, religiões, artefatos culturais e todos os demais dispositivos que formam a subjetividade e resultam em atitudes e comportamentos pessoais e coletivos.

A partir da inserção transversal de conhecimentos sobre o próprio corpo, das relações de gênero e das derivas que constituem a sexualidade humana, torna-se possível o planejamento e a qualificação das relações afetivas, sexuais e sociais que constituirão a vida dos jovens em formação. O fortalecimento da estima e a oferta de subsídios colaboram para que desfrutem dos próprios prazeres com responsabilidade

Não existem "receitas prontas". É necessário experimentar, arriscar, criar. A proposição de debates e discussões pode (e deve) envolver as 
famílias e elucidar muitas dúvidas. O uso de dinâmicas, jogos, vídeos e livros paradidáticos é necessário e poderá complementar as atividades desenvolvidas em sala de aula.

Educar para a cidadania e para o exercício e respeito aos direitos humanos requer conhecimento e reconhecimento da relevância da formação de valores que refletem as práticas sociais das futuras gerações.

\section{REFERÊNCIAS}

BRASIL. Secretaria de Educação Fundamental. Parâmetros Curriculares Nacionais: pluralidade cultural, orientação sexual. Brasília: MEC/SEF, 1997. Disponível em: < http://portal.mec.gov.br/ seb/arquivos/pdf/livro101.pdf>. Acesso em: 26 set. 2015.

BRITZMAN Deborah P. O que é essa coisa chamada amor: identidade sexual, educação e currículo. Educação e Realidade, Porto Alegre, v. 21, n.1, p. 71-96. jan./jun. 1995.

FURLANI, Jimena. Educação sexual na sala de aula: relações de gênero, orientação sexual e igualdade étnico-racial numa proposta de respeito às diferenças. Belo Horizonte: Autêntica, 2011.

LOURO, Guacira Lopes. Gênero, sexualidade e educação: Uma perspectiva pós-estruturalista. Petrópolis: Vozes, 1997.

PIMENTA, Melissa de Matos. Cidadania e Direitos Humanos. In MEIRELLES, Mauro, RAIZER, Leandro, MOCELIN. Cidadania e Direitos Humanos. Porto Alegre: LAVIECS/CirKula, 2015 .

ROCHA, Rosa Margarida de Carvalho. Pedagogia da diferença. A tradição oral africana como subsídio para a prática pedagógica brasileira. Belo Horizonte: Nandyala, 2009.

SANTOS, Angela M. et al. Orientações Curriculares para Educação em Direitos Humanos, Gênero e Diversidade Sexual. Secretaria de Estado de Educação. Mato Grosso. 2010.

SERRÃO, Margarida. Aprendendo a ser e a conviver. São Paulo: FTD, 1999.

SILVA, Rosimeri Aquino da. O ponto fora da curva. In: MEYER, Dagmar Estermann; SOARES, Rosângela de Fátima Rodrigues (Orgs.). Corpo, gênero e sexualidade. Porto Alegre: Mediação, 2004. cap. 6, p. 85-94.

. Notas sobre o sexo da educação. In: PENALVO, Claudia; BERNARDES, Gustavo (Orgs.). Tá difícil falar sobre sexualidade na escola? Porto Alegre: SOMOS, 2009. p. 18-25.

SILVA, Tomaz Tadeu da. Teorias de identidade: uma introdução às teorias do currículo. Belo Horizonte: Autêntica, 2000.

ZABALA, Antoni. A prática educativa: como ensinar. Porto Alegre: Artmed, 1998. 



\section{EDUCAÇÃO A DISTÂNCIA: UMA FERRAMENTA POSSIVEL DE INCLUSÃO E REINSERÇÃO DE LGBTS AO ESPAÇO EDUCACIONAL}

Amilton Gustavo da Silva Passos

"Hoje decidi fazer algo de diferente. Decidi ficar na minha casa, na minha piscina, bebendo meus bons 'drink', na Europa, Espanha, e dividindo com vocês esses momentos meus”. Essas são as primeiras frases de um vídeo que ficou muito conhecido no Brasil no ano de 2010². A situação dizia respeito a uma travesti banhando-se em uma piscina em uma mansão na Espanha. O vídeo, tornado público inicialmente pela rede social YouTube, foi a origem de um jargão utilizado até hoje: "Se isso é estar em uma pior... P*rra! O que quer dizer estar bem?”.

Quando nos colocamos a pensar sobre o que é ser homem e/ou o que é ser mulher em nossa sociedade e em nosso tempo elencamos uma série de características disponíveis para nós e montamos uma imagem mental dessa figura generificada. Esses parâmetros, que geralmente, estão fundamentados em matrizes normativas de corpo, gênero e sexualidade recaem sobre a existência LGBT. Partimos de parâmetros culturais presentes nas formas com que a linguagem se refere a essas pessoas, bem como na maneira que

1 Vídeo disponível em: <https:/www.youtube.com/watch?v=ikzC29rV75A>. Acesso em: 16 nov. 2015. 
essas pessoas se tornam visíveis para nós em um dado momento histórico. Talvez o vídeo citado seja um bom exemplo. Nesse caso, a travesti que protagoniza o vídeo foi capturada por uma visibilidade caricata, um retrato de si inclinado para a comédia. O massivo compartilhamento desse vídeo certamente corroborou para a vinculação da identidade travesti à condição de caricatura; algo que devemos achar engraçado, uma pessoa que não devemos levar a sério.

Certamente as travestis se tornam visíveis na nossa sociedade de uma série de outras formas, como por exemplo a vinculação à pobreza, à prostituição, à criminalidade, à condição de não-humanidade. Incidem sobre gays, por sua vez, vinculações com a promiscuidade, transmissão de HIV, conduta amoral. Enfim, cada letra da sigla LGBT é alvo de uma série de construções históricas reiteradas atualmente sobre sua existência. Tais vinculações têm efeito sobre a trajetória de vida dessas pessoas. Ser identificado como LGBT pode carregar consigo um altíssimo grau de vulnerabilidade. Essa população carrega nas suas histórias de vida e nos seus corpos duras experiências de violência psicológica, simbólica e, por vezes, física. Para entender melhor como a identidade LGBT pode conferir uma situação de vulnerabilidade, é importante conhecer alguns conceitos relacionados ao gênero e à sexualidade e como eles se relacionam.

Sexo e gênero são conceitos que acompanham os estudos feministas desde muito tempo; entretanto, a forma como entendemos cada um desses parâmetros e a maneira como eles se relacionam e nos tornam sujeitos dessa relação têm sido tema de fortes debates, atualizações, novas abordagens, divergências e convergências. Aproximo meus olhares para as relações de gênero através da perspectiva cunhada pela filósofa americana Judith Butler (2003). Segundo a autora, retomando em primeiro momento os pensamentos de Luce Irigaray e Monique Wittig, gênero é um ato, uma série de práticas cotidianas respaldadas pelos parâmetros normativos produzidos pelas matrizes estabilizadoras do sexo biológico. Em outras palavras, o gênero é performativo, e seus efeitos são produzidos no momento em que ele é praticado. O que compreendemos como o que é “ser mulher", por 
exemplo, se torna visível na prática cotidiana dos elementos atribuídos ao feminino em determinada cultura e tempo.

Butler alerta também para como os binarismos biológicos atuam como produtores dos parâmetros de gênero. Historicamente, as teóricas feministas têm investido no esforço de ressaltar o fundamento cultural do gênero, negando sistematicamente qualquer determinismo biológico. Para a autora, gênero e sexo são, sim, categoria distintas, embora se posicionem em uma relação de produção simultânea em que o que se pensa sobre o sexo produz parâmetros de gênero, e a performance de gênero também reitera o binarismo do sexo. Pensar no sexo como inequivocamente binário, sendo que cada polo seria idêntico a si mesmo, é, segundo a autora, mais uma produção discursiva que torna o sexo sujeito de um saber biológico contemporâneo. Ela não nega a materialidade dos corpos; entretanto, argumenta que pensar no sexo como algo dado, ontológico e suspenso de qualquer análise crítica é mais um efeito de uma discursividade atual.

Nessa ambientação, o que identificamos como homem/mulher é o produto da inteligibilidade que exigimos uns dos outros e praticamos em nós mesmos. Digamos que uma pessoa, por ser dotada de um pênis, tenha seu corpo designado como do sexo masculino no nascimento, perceba a si mesmo como um homem nos parâmetros do que é "ser homem" na nossa cultura/tempo e pratique o desejo pelo sexo/gênero oposto. Essa pessoa seria então dotada de inteligibilidade, ao passo que o sexo, o gênero e o desejo estariam em "linearidade", estabeleceriam uma relação "coerente". Vale ressaltar que o que chamo aqui de linearidade ou coerência são apenas construções arbitrárias que se relacionam com os saberes de nossa época.

As leis culturais hoje, produzidas através de ligações entre sexo biológico, gênero culturalmente construído e a expressão do afeto e do desejo sexual tratam de fiscalizar, proibir e punir através de estratégias enunciativas, práticas e instituições qualquer incoerência nessa linearidade. Ao passo que se instituem certas formas de se viver o trinômio sexo/gênero/ desejo como culturalmente inteligíveis, torna-se inevitável a disseminação de outras identidades de gênero e sexualidades, bem como suas múltiplas possibilidades de combinação, como dissidentes e/ou desviantes. 
Nesse ponto é importante definir o que entendo por identidade de gênero. Voltando ao pensamento que dá início a este texto, com a pergunta “o que é ser mulher?”, imediatamente iniciamos a montagem mental de um corpo generificado e para tal nos valemos dos parâmetros disponíveis no nosso tempo e cultura para a construção dessa imagem. A identidade de gênero se dá na percepção singular e pessoal de como o sujeito se relaciona com elementos atribuídos a esse ou àquele gênero (Jesus, 2012). O conceito de identidade de gênero, além de enfatizar o caráter cultural-histórico do gênero, traz consigo o elemento da autoidentificação, ou seja, o que determina o gênero com o qual alguém se identifica é a percepção de si posta em relação aos parâmetros do que é "ser homem” ou o que é "ser mulher".

Entretanto, somos seres culturais e como tal estamos inseridos em relações de poder. Enquanto uma pessoa cujo corpo foi designado como feminino e apresenta uma identidade de gênero feminina é lida socialmente como uma existência coerente a partir dos parâmetros de sexo/gênero, uma pessoa cujo corpo foi designado como masculino e apresenta uma identidade de gênero feminina é lida como incoerente e desviante a partir desses mesmos parâmetros ${ }^{2}$. Existe uma série de práticas que operam em todas as esferas do cotidiano que atuam como reguladores do corpo, da identidade de gênero e da sexualidade de todos nós. Vale ressaltar que muitas dessas práticas são intencionais, ao passo que outras estão muito mais no âmbito do discurso. Ambas produzem efeitos sobre nós em certa medida e em certas situações.

Somos ensinados nas escolas, em aulas de ciências nas séries iniciais, por exemplo, que a categoria "ser vivo" pode ser delimitada por aqueles indivíduos que nascem, crescem, reproduzem e morrem. O que pode parecer uma enunciação banal carrega um aprendizado produzido no interior da normatividade em que vivemos. Afinal, está presente no saber

\footnotetext{
2 As pessoas que percebem a si mesmas dentro dessa coerência ou inteligibilidade construída socialmente entre o sexo ao qual foi designada ao nascer e o gênero com o qual se identificam são denominadas pessoas cisgênero ou pessoas cis*. Por outro lado, uma pessoa que não apresenta uma linearidade entre o sexo e o gênero é denominada travesti, transexual, transgênero ou pessoa trans*. Existem diferenças conceituais entre essas quatro últimas categorias que podem ser esclarecidas nos textos $O$ que é cissexismo? e Trans* como termo guarda-chuva, disponíveis em: <http://transfeminismo.com>. Último acesso em: 19 nov. 2015.
} 
coletivo que pessoas homossexuais não são capazes de se reproduzir ${ }^{3}$. Perceba que talvez não exista a intencionalidade de marcar um "desvio" no modo de vida das pessoas homossexuais; entretanto, o efeito desencadeado por essa enunciação, reiterada infindavelmente na vida escolar, torna gays, lésbicas, enfim, qualquer pessoa dotada de um desejo não-heterossexual, sujeito desse saber.

Borrillo (2010) entende que homofobia são práticas de hostilidade que têm como alvo pessoas homossexuais. Entretanto, essas práticas se dispersam em diversos níveis da nossa sociedade, de diferentes formas, agindo diferentemente de pessoa para pessoa. É uma modalidade de violência que possui muitas facetas, estratégias e efeitos. O autor diferencia algumas das formas pelas quais tais práticas se manifestam. O fenômeno da homofobia - ainda que esse conceito tenha surgido muito recentemente da maneira que o conhecemos - pode ser identificado em diversas esferas de nossa sociedade.

O Brasil, mesmo que legalmente falando seja considerado um país laico, permanece atravessado por diversos saberes produzidos no interior das crenças culturalmente presentes. Ainda segundo Borrillo (2010), a aversão cristã aos homossexuais procuraria justificativa na condição de suas práticas estéreis. Segundo a doutrina, para esse autor, a prática sexual para fins não reprodutivos configuraria algo antinatural ou pecaminoso. Dessa forma, considerando a prática sexual entre pessoas do mesmo sexo como estéril, manter práticas homossexuais seria algo a ser combatido.

O caráter patológico da homossexualidade produzido a partir de construções de saberes médicos também atua como uma modalidade de violência. Ancorado não somente nas noções de esterilidade reprodutiva das práticas sexuais entre pessoas do mesmo sexo, mas, sobretudo, no surto de HIV/AIDS, no passado chamada "peste gay", o saber médico tem sistematicamente convertido em patologia as identidades não heterossexuais.

3 Mesmo esse pensamento não está correto. Se pensarmos em uma relação entre um homem trans* homossexual e um homem cis* homossexual, a reprodução em que o óvulo do primeiro indivíduo é fecundado pelo espermatozoide do segundo indivíduo é perfeitamente possível. 
O termo homofobia pode dar nome a práticas que variam desde um xingamento, à não admissão de alguém em uma vaga de emprego, à exclusão de grupos sociais na escola, até a violência física à qual essas pessoas estão vulneráveis. Obviamente, as práticas de violência que acabo de descrever são, sim, do âmbito do intencional. Violências que muitas vezes são motivadas e fundamentadas nos saberes normativos difundidos em meio aos discursos médicos, religiosos, entre outros. São práticas que ferem, marcam, matam e ensinam. Ensinam a quem sobreviveu a uma violência desse tipo que a expressão "desviante da norma” o deixa vulnerável à violência, que a pessoa não deve se sentir segura. Ensinam a quem nunca viveu esse tipo de violência, mas está ciente dela, que pode sofrer uma agressão a qualquer momento, em qualquer lugar, seja nas ruas, na escola ou até mesmo em casa.

A violência parece ser uma prática produzida como estratégia que se vale de tentativas sistemáticas e reiterativas de posicionar certo sujeito enquanto desviante da norma. Em outras palavras, não há como sugerir que a violência contra diferentes sujeitos, mesmo sendo considerados dissidentes à norma, atue sobre eles da mesma forma. A homofobia é uma modalidade de violência que tem um sujeito aparentemente bem delimitado: o homem cis homossexual. As estratégias táticas de poder que são exercidas sobre esses indivíduos se configuraram, a partir de um campo de saber construído, sobre uma representação desse alvo. Ou seja, as estratégias de violência homofóbica se configuram de uma maneira muito específica, referente à trajetória também muito singular do seu sujeito-alvo.

Partindo desse raciocínio, é possível sugerir que a violência contra uma mulher cis lésbica, por exemplo, possa, em primeira análise, parecer semelhante à praticada contra um homem gay. Entretanto, o atravessamento de gênero parece tornar essa primeira modalidade de violência ligeiramente diferente da segunda. A misoginia e o sexismo são componentes muito comuns nas modalidades de violência praticadas contra mulheres cis homossexuais, muito mais do que para homens cis gays. Talvez seja insuficiente tentar enquadrar as práticas de violência contra mulheres cis lésbicas no escopo da homofobia. Uma lesbofobia que contemple as especificidades do sujeito- 
alvo dessa violência poderia, em primeira análise, servir de maneira mais completa.

Certamente, as modalidades de violência vividas por pessoas que se identificam como travestis diferem das vividas por homens cis gays e mulheres cis lésbicas. Primeiramente, há uma diferença crucial entre essas modalidades de violências: enquanto as práticas hostis contra homens cis homossexuais, por exemplo, parecem estar vinculadas a uma aversão à prática do desejo desviante, as práticas hostis cujo alvo é a travesti, por sua vez, têm origem na identidade de gênero. Dessa forma, práticas de violência que têm como alvo travestis ou pessoas transgênero são denominadas transfobias.

Assim como a homofobia e a lesbofobia, a transfobia também é o nome dado a uma série de práticas que podem ser mais ou menos visíveis e que tomam pessoas trans*, em especial travestis, como alvo das regulações normativas sobre o corpo, identidade de gênero e desejo. Essas práticas estão dispersas no cotidiano, nas instituições e na forma com que essas pessoas são retratadas. Perceba que imaginar que todas as travestis são caricatas, violentas ou prostituem-se é por si uma prática transfóbica por tomar como referência um modo de visibilidade que não compreende a multiplicidade desse grupo.

No nível institucional, uma série de práticas é desferida e torna as pessoas trans* sujeito dos efeitos da norma. Enquanto que por um lado os saberes médicos sobre a existência trans* parecem se concentrar nas tentativas sistemáticas de patologizar essas identidades, por outro existe um vácuo absoluto sobre as necessidades básicas em saúde específicas dessa população. Um exemplo infeliz de como essa normatividade reverbera nas instituições é a inexistência de profissionais da saúde genital que possam atender de forma minimamente satisfatória uma mulher trans* que foi submetida a uma readequação ou cirurgia transexualizadora ${ }^{4}$.

4 Embora eu não concorde com esse termo, "cirurgia transexualizadora" é o termo utilizados nos manuais médicos (Machado, 2008). 
A instituição escolar certamente tem papel fundamental como ferramenta de reiteração e atualização das normas sexuais e de gênero que governam nossos corpos. Tornamo-nos sujeitos de uma série de práticas disciplinares que agem sobre nossos corpos, modelando-os através de uma tecnologia eficiente, regular, incessante e respaldada nas normas culturais do nosso tempo.

O corpo humano entra numa maquinaria de poder que o esquadrinha, o desarticula e o recompõe. [...] Ela define como se pode ter domínio sobre o corpo dos outros, não simplesmente para que façam o que se quer, mas para que operem como se quer, com as técnicas, segundo a rapidez e a eficácia que se determina. A disciplina fabrica assim corpos submissos e exercitados, corpos "dóceis". [...] A "invenção" dessa nova anatomia política não deve ser entendida como uma descoberta súbita. Mas como uma multiplicidade de processos muitas vezes mínimos, de origens diferentes, de localizações esparsas, que se recordam, se repetem, ou se imitam, apoiamse uns sobre os outros, distinguem-se segundo seu campo de aplicação, entram em convergência e esboçam aos poucos a fachada de um método geral. Encontramo-los em funcionamento nos colégios, muito cedo; mais tarde nas escolas primárias; investiram lentamente o espaço hospitalar; e em algumas dezenas de anos reestruturam a organização militar. (Foucault, 1998, p. 165)

Ensinam-nos como devemos viver, como devem usar nossos corpos, quais partes podemos usar, quais partes devem ser renegadas, quais partes não devem ser citadas. Aprendemos que qualquer outra forma de operar com nosso corpo, qualquer identidade de gênero diferente da escolhida para nós, torna-nos indivíduos dotados de uma vida que ninguém gostaria de 
viver, uma vida não vivível. Todas as vezes que os(as) professores(as) das séries iniciais dividem uma turma de crianças em um grupo de meninos e um grupo de meninas eles(as) dizem, mesmo que não intencionalmente, que existem apenas essas duas possibilidades e que não cabe a você escolher o grupo ao qual você deverá se juntar.

$\mathrm{Na}$ vida cotidiana e em especial na escola, um dos elementos que conferem vulnerabilidade a quem não se compreende dentro da norma é a passabilidade ${ }^{5}$. Bohm (2009) relata a experiência de vida de pessoas trans* na escola; segundo a autora, são absolutamente corriqueiras as práticas de desrespeito à identidade de gênero das pessoas trans* na escola. Uma das interlocutoras que participaram da pesquisa da autora relata que no momento da matrícula o ato de expor o nome designado a ela no nascimento, um nome que remete a uma identidade masculina, causava estranhamento, repulsa, piadas, violência simbólica.

Também está presente na pesquisa uma situação muito frequente nas falas das pessoas trans*: o uso do banheiro. Para pessoas cis*, usar um banheiro pode parecer um ato intuitivo, pré-reflexivo, livre de qualquer contestação. Para pessoas trans*, por outro lado, essa prática pode ser um espaço de exposição à vulnerabilidade. Uma interlocutora é categórica ao dizer que "preferia ficar sem fazer xixi, apertada a manhã toda, a entrar em um dos banheiros" (Bohm, 2009, p. 59). Os relatos são convergentes em dizer que o uso desse espaço é um momento de tensão e medo, afinal no banheiro masculino elas se tornam vulneráveis à violência dos homens cis* e no banheiro feminino elas se tornam vulneráveis à violência das mulheres cis*.

\footnotetext{
5 Passabilidade é um termo cunhado pelas teóricas transfeministas e diz respeito à capacidade de parecer estar dentro da norma. Uma passabilidade cis*, por exemplo, está relacionada com uma pessoa trans* que passaria despercebida como tal. Em outras palavras, quando a condição de pessoa trans* não é identificada imediatamente ou de forma alguma. Torna-se fundamental tencionar esse conceito a partir do momento em que a passabilidade surge como um marco normativo, entendido como um lugar comum onde todas as pessoas trans* têm o objetivo de chegar. Grande parte da força normativa que a passabilidade adquiriu pode ser vinculada ao fato de que os grandes ícones presentes na mídia e retratados com uma existência trans* bem-sucedida são, via de regra, pessoas dotadas de alta passabilidade. Outro ponto é que muitas vezes essa característica está ligada ao acesso a intervenções cirúrgicas e hormonais sobre o corpo, o que adiciona um recorte econômico a esse conceito. Enquanto todas as pessoas trans* estão vulneráveis à violência, as que não têm acesso à passabilidade certamente se inserem em um grupo ainda mais vulnerável. Disponível em: <http://transfeminismo.com/por-um-dialogo-sobre-passabilidade-visibilidade-e-protagonismo-dentro-da-comunidade-trans/ $>$. Último acesso em: 20 nov. 2015
} 
A escola insiste em assegurar um espaço de não-lugar para a população de pessoas trans*. Um não-lugar de gênero, um não-lugar institucional, um não-lugar humano. Existe um sistemático silêncio que se estende e engloba a existência de pessoas trans* na escola. Estratégias de invisibilização, como desconsiderar o nome social das pessoas trans*, expondo-as a situações diárias de constrangimento, ignorar claras situações de violência transfóbica, reproduzindo o modelo binário e normativo de gênero nos currículos, entre outros (Junqueira, 2012). A regularidade dessas práticas transforma o espaço escolar em um campo inóspito para a permanência de qualquer pessoa dotada de dissidências sexuais e de gênero, em especial das pessoas trans*.

Não existe uma estatística exata que englobe a proporção de pessoas trans* que permanecem resistindo às forças de repulsão produzidas pela escola, que evadiram da escola por conta de transfobia, quantas concluíram o ensino básico ou médio, quantas estão nas universidades, nas pósgraduações. Entretanto, as pesquisas que se preocupam em investigar a inclusão de pessoas trans* na escolar apontam uma faixa em média de 80 a $90 \%$ de pessoas trans*, em especial travestis, que evadem da escola por inúmeros motivos que giram em torno da transfobia e que, por conta disso, não concluem o ensino médio (Bohm, 2009).

Utilizo aqui pontos que dizem respeito majoritariamente às pessoas trans*; entretanto, essas forças de repulsão produzidas pela instituição da escola também atingem pessoas cis lésbicas, gays, bissexuais ou qualquer outra existência não-normativa. É preciso salientar que as organizações de movimento social que procuram dar visibilidade à especificidade da violência contra pessoas trans* ainda são muito recentes quando comparadas com as do movimento gay ou lésbico, por exemplo. Isso tem efeito direto sobre a pouca visibilidade das pessoas trans*, bem como sobre a falta de preparo da instituição da escola em ser um local acolhedor para essa população. De certa forma, entre a população LGBT, as pessoas trans* estão inseridas em situações de maior vulnerabilidade do que as outras letras da sigla. 


\section{EDUCAÇÃO A DISTÂNCIA: DESESTABILIZANDO AS RELAÇÕES DE PODER NA EDUCAÇÃO}

Fica muito claro que a escola não é um espaço acolhedor para pessoas LGBT, em especial para pessoas trans*. Embora já exista um movimento de resistência na direção de pressionar essa instituição na direção da inclusão da diversidade sexual e de gênero, existe um longo caminho até que esse espaço deixe de representar risco. A evasão escolar, exclusão do espaço familiar e a dificuldade de empregabilidade compõem um quadro de uma trajetória social cruel frequentemente acoplado às existências LGBT, em especial às pessoas trans*.

A instituição da escola se constitui como uma ferramenta disciplinar desde o projeto arquitetônico, através das suas práticas cotidianas, relações de poder, configuração das salas de aula no espaço. A escola é um local de capilarização do poder, em que os alunos são divididos em turmas ordenadas por um recorte etário, separados em grupos reconhecíveis (Foucault, 1998), operando seus currículos (Silva, 2010), fazendo funcionar um aparato normativo quem tem excelência em disciplinar e produzir corpos dóceis.

Segundo Nogueira (1996), a educação a distância surge como uma urgência da contemporaneidade globalizada. Vivemos em um mundo em que as tecnologias nos capturam desde muito cedo. Essa tecnologia se tornou uma peça fundamental no mercado, na sociabilização, no trânsito de informações, nas relações sociais, dispersando-se de tal forma que a vida sem o uso de tecnologias passa a ser vista com estranhamento. Para o autor, era apenas uma questão de tempo para que a educação acompanhasse o ritmo da inserção tecnológica.

A educação a distância surge para suprir em curto prazo a dificuldade de alcance que limitava a atuação da escola nos locais mais distantes dos centros urbanos, seja essa limitação de ordem espacial ou temporal. Essa modalidade de educação atenderia tanto pessoas que estivessem distantes fisicamente quanto as que possuíssem disponibilidade de horários incompatíveis. Outra característica da educação à distância é o caráter muito mais autônomo do alunado (Belloni, 2002). Existe uma autonomia muito maior em seguir 
o seu próprio ritmo de aprendizado ou execução de alguma tarefa. Essas características que citei até aqui tornam possível um tensionamento.

As relações de poder não podem ser pensadas como estruturas fixas, algo que possa ser reduzido a uma relação simples, reprodutível e que atue sobre todos da mesma maneira; pelo contrário, são tão mais eficientes quanto forem específicas, capilarizadas, individuais, da ordem das micropráticas (Foucault, 1998). Argumentei anteriormente que a escola ainda é um ambiente normativo, disciplinar, docilizador, policialesco, autoritário, simbólica e muitas vezes fisicamente violento; em outras palavras, um campo de exercício do poder.

Embora o poder não possa ser descrito como uma estrutura fixa, na escola ele parece estar fundamentado em certos elementos categóricos reiterados como indispensáveis à escola como a conhecemos hoje. Elementos como rotina de horário de entrada na instituição, a divisão temporal das disciplinas ao longo de cada dia na semana, recreio, horário de merenda, turmas divididas e ordenadas por ano letivo, configuração espacial, entre outros, produzem os fundamentos para uma série de relações de poder exercidas na escola. O espaço físico, por exemplo, produz subsídios para o acesso generificado ao banheiro. Nesse sentido, a educação a distância pode produzir um substancial efeito de inclusão à diversidade sexual e de gênero que a escola tradicional ainda não conseguiu.

Se a educação respondeu a uma urgência da cultura imersa na tecnologia que vivemos, a educação a distância, por sua vez, pode ser utilizada como uma ferramenta de inclusão em resposta à visibilidade que grupos a tanto tempo marginalizados assumiram atualmente. Não sugiro com isso que devemos deixar de lado todo o movimento que tenta tornar a escola um espaço acolhedor, mas não posso deixar de levar em consideração que, nesse momento, estar em um espaço escolar é uma situação que confere risco à população de gays, lésbicas, bissexuais e, em especial, à de travestis e de transexuais. 
Tive a oportunidade de entrevistar algumas pessoas LGBT sobre o assunto. De forma geral, as narrativas descrevem situações de violência vividas no espaço escolar. A Colaboradora 1, que é travesti, disse:

Eu terminei a escola no tempo certo por que eu era desaforada. Eles [colegas de turma] me xingavam um monte. Às vezes eu fingia que não estava nem aí, às vezes eu tirava umas brincadeiras pesadas com eles, briguei um monte na escola. Na medida do possível minha família me apoiava. Daí eu tive menos problemas. Mas eu fico pensando nas gurias que são mais pobres. Sei lá. É cruel pra elas.

Essa colaboradora foi aluna de educação a distância. Durante a entrevista, ela diz que nunca pensou nessa modalidade de educação como uma alternativa para prevenir a violência contra LGBT. Entretanto, concorda que para muitas o espaço da escola é um ambiente de medo e não ter que ir fisicamente a esse lugar pode ser usado como argumento de convencimento para reinserir travestis à escola. Eu acredito que não apenas travestis, mas qualquer pessoa LGBT que tenha evadido da escola por violência relacionada com sua sexualidade ou identidade de gênero pode enxergar na educação à distância uma forma mais imediata de retornar aos estudos.

A colaboradora 2, que é uma mulher trans*, alerta:

Claro que fazendo um curso a distância eu não corro o risco de apanhar na sala de aula, mas tem outros tipos de violência, né? Da vez que eu fiz uma pós a distância eles sempre erravam meu nome. Tive que reclamar um milhão de vezes pra coordenação acertar meu nome [nome social] na lista. No fim meu certificado saiu com o nome certo, pelo menos.

Especialmente no caso das pessoas trans*, não estar fisicamente presente em um local faz cair por terra um dos principais motivos de evasão escolar para essa população: a violência física. Não há o olhar fulminante dos 
professores que transmite a sensação de não pertencimento àquele lugar. Não há o caminho de ida e volta para a casa que dá espaço à vulnerabilidade. A educação a distância pode possibilitar um resultado em curto prazo, uma resposta à urgência da massiva evasão escolar que exclui LGBTs.

Claro que devemos continuar problematizando e pressionando a instituição da escola na direção de se tornar um local acolhedor para a diversidade. Permaneço acreditando que a socialização, as relações interpessoais, o diálogo com os professores e os colegas de turma, o contato crítico com uma instituição disciplinar como essa sejam experiências enriquecedoras e pedagógicas. Mas não posso ignorar o fato de que uma grande quantidade de pessoas LGBT já evadiu da escola por motivos de violência e que dificilmente voltariam a frequentar esse espaço. Essas pessoas não podem esperar, precisam de uma alternativa imediata que o ensino presencial não pode oferecer agora. Não vejo a inclusão de pessoas LGBT através da educação a distância como uma medida que esgota a problemática da violência na escola, mas sim como uma ferramenta de resgate para quem não se sente contemplado pela modalidade presencial de educação.

\section{REFERÊNCIAS}

BELLONI, Maria Luiza. Ensaio sobre a educação a distância no Brasil. Educação \& Sociedade, Brasília, v. 78, n. 1, p. 117-142, abr. 2002.

BOHM, Alessandra Maria. Os "Monstros" e a Escola: Identidade e escolaridade de sujeitos travestis. 2009. 103f. Dissertação (Mestrado) - Curso de Educação, Universidade Federal do Rio Grande do Sul: Porto Alegre, 2009.

BORRILLO, Daniel. Homofobia: história e crítica de um preconceito. Belo Horizonte: Autêntica Editora, 2010.

BUTLER, Judith. Problemas de Gênero: feminismo e subversão da identidade. Rio de Janeiro: Civilização Brasileira, 2003. 236p. (Sujeito e Histórica)

CRUZ, Elizabete Franco. Bathrooms, travestites, gender relations and differences in school's daily life. Rev. psicol. polít., São Paulo , v. 11, n. 21, jun. 2011 .Disponível em: < http://pepsic. bvsalud.org/scielo.php?script $=$ sci_arttext\&pid $=$ S1519-549X2011000100007\&lng $=$ pt\&nr $\mathrm{m}=$ iso\&tlng $=\mathrm{pt}>$. Acesso em: 20 nov. 2015. 
FOUCAULT, Michel. Vigiar e Punir: nascimento da prisão. Petrópolis: Editora Vozes, 1998.

JESUS, Jaqueline Gomes de. Identidade de gênero e políticas de afirmação identitária. In: Congresso internacional de estudos sobre a diversidade sexual e de gênero da ABEH, 6, 2012, Salvador. Anais. Salvador: 2012. p. 1-15.

JUNQUEIRA, Rogério Diniz. Pedagogia do armário e currículo em ação: heteronormatividade, heterossexismo e homofobia no cotidiano escolar. In: MILSKILCI, Richard. Discursos fora da Ordem: deslocamentos, reinvenções e direitos. São Paulo: Annablume, 2012. p. 25.

MACHADO, Paula Sandrine. O Sexo dos Anjos: Representações e práticas em torno do gerenciamento sociomédico e cotidiano da intersexualidade. 2008. 265f. Tese (Doutorado) - Curso de Antropologia Social. Universidade Federal do Rio Grande do Sul: Porto Alegre, 2008.

NOGUEIRA, Luís Lindolfo. Educação a distância: Colocar as novas tecnologias da comunicação a serviço da educação ajuda a diminuir as distâncias sociais e pode propiciar, a cada vez mais pessoas, o direito ao saber. Comunicação e Educação, São Paulo, v. 5, n. 1, p.34-39, abr. 1996.

SILVA, Tomaz Tadeu da. Documentos de Identidade: uma introdução às teorias do currículo. 3. ed. Belo Horizonte: Autêntica Editora, 2010 



\section{QUANDO AIDS, GÊNERO, SEXUALIDADE E DIREITOS HUMANOS SE ENCONTRAM NO TERRITÓRIO ESCOLAR}

Cláudio Nunes

Fernando Seffner

\section{COMBINAÇÕES EXPLOSIVAS EM SALA DE AULA}

Qualquer professor ou professora com poucos anos de docência sabe o quanto questões de gênero e sexualidade habitam a sala de aula. A criança entra na escola atualmente com seis anos de idade e cada vez mais será comum que ela siga estudando até o final do ensino médio, quando estará com idade ao redor de dezoito anos. Associado a isso, vale lembrar a ampliação do turno integral nas redes públicas, com crianças e jovens cruzando os portões escolares em torno de sete e meia da manhã, fazendo sua primeira merenda, indo para a sala de aula, depois intervalo para recreio, mais aulas, intervalo de almoço no refeitório, turno da tarde reservado para aulas, oficinas, atividades esportivas e/ou momentos de estudo individual ou em grupo, lanche ou janta ao final do dia e, algumas vezes, inclusive oportunidade para banho no vestiário da escola antes do retorno às suas casas. Ou seja, é na escola que cada vez mais meninos e meninas vão atravessar uma parte importante da etapa juvenil de suas vidas e é na escola que vão reconhecer as 
possibilidades eróticas do seu corpo, estabelecer relações de afeto, amizade, namoro, aprender a respeitar as diferenças de gênero, debater sobre as relações com equidade de gênero, conhecer e respeitar a diversidade de orientações sexuais e de modos de ser menino e menina. Coerente com isso, o tema das relações de gênero e sexualidade foi um dos escolhidos por diversos alunos do curso que gerou este livro, na ótica da Educação em Direitos Humanos.

O exercício da sexualidade, em qualquer período histórico, comportou agravos de saúde. Se hoje temos a AIDS a assombrar a vida sexual, vale lembrar que antes tivemos a sífilis e antes dela uma sucessão enorme de doenças relacionadas ao ato sexual, sem contar os problemas de saúde que podem advir da gestação, parto e puerpério. Uma abordagem adequada das relações afetivas e sexuais deve envolver esse tema, mas deve se ter cuidado em não usar a doença para assustar os sujeitos em relação à vida sexual, atitude que não produz esclarecimentos e não ajuda a ter uma vida feliz. $\mathrm{O}$ propósito deste texto é duplo: apresentar um conjunto importante de informações acerca da AIDS e dos modos de lidar com ela, a partir da experiência no município de Porto Alegre, e vincular as questões de gênero, sexualidade e AIDS com o campo da Educação em Direitos Humanos e os modos como elas podem acontecer no território escolar, dando mais segurança a professores e professoras na abordagem de tema que, reconhecemos, é altamente polêmico. Conhecer a estrutura e os programas de uma política de atenção à AIDS e doenças sexualmente transmissíveis ajuda professores e professoras a planejar estratégias pedagógicas em sintonia com os profissionais de saúde.

\section{PANORAMA DA AIDS EM PORTO ALEGRE}

Segundo o Ministério da Saúde, os primeiros casos de AIDS no Brasil foram identificados no início da década de 1980, tendo sido registrados predominantemente entre gays adultos, usuários de drogas injetáveis e hemofílicos. Passados trinta anos, o país tem como característica uma epidemia estável e concentrada em alguns subgrupos populacionais em situação de 
vulnerabilidade. A taxa de detecção de AIDS no Brasil tem apresentado estabilização nos últimos dez anos, com uma média de 20,5 casos para cada 100 mil habitantes. Também se observa estabilização da taxa na região Sul, com uma média de 31,1 casos para cada 100 mil habitantes; ou seja, mais elevada do que no restante do país. De acordo com o último Boletim Epidemiológico HIV/AIDS, publicado em 2015, foram notificados nos sistemas de monitoramento no estado do Rio Grande do Sul 757.042 casos de AIDS, acumulados de 1980 a junho de 2014, sendo 491.747 (65,0\%) no sexo masculino e 265.251 (35\%) no sexo feminino ${ }^{1}$.

A manutenção das taxas elevadas na incidência de casos de AIDS tem chamado atenção para epidemia na cidade de Porto Alegre na última década, em contraste com a queda da incidência em outros estados e capitais. O município de Porto Alegre, conforme o boletim epidemiológico de 2014², apresenta as maiores taxas de detecção de casos de AIDS do país, tendo 96,2 casos de AIDS para cada 100.000 habitantes, o que é muito superior à já referida média nacional de 20,5 casos de AIDS para cada 100 mil habitantes. Foram notificados em residentes de Porto Alegre, desde o início da epidemia, em 1983, a 30 de junho de 2015, 27.278 casos de AIDS. A razão de sexo apresentou um ápice de 13 homens para cada mulher com AIDS em 1987 e, em 2002, 1,2 casos de homens para uma mulher. Do total, 96,5\% casos foram diagnosticados em indivíduos maiores de 13 anos e 3,5\% em crianças menores de 5 anos $^{3}$. A variável categoria de exposição ao HIV de 2007 a 2014 continua evidenciando a transmissão heterossexual, com média de 55,8\% dos casos, seguida da transmissão homo/bissexual, com 13,3\% dos casos e, por fim, o uso de drogas injetáveis, que representa $3 \%$ dos casos. ${ }^{4}$

No recorte raça/cor, a distribuição da incidência dos casos de AIDS em Porto Alegre indica que a epidemia é mais pronunciada em "negros/

\footnotetext{
1 Disponível em: <http://www.aids.gov.br/system/tdf/pub/2015/90/boletim_hepatites_2015.pdf?file $=1 \&$ type $=$ n ode\&id $=90 \&$ force $=1>$. Acesso em: out. 2015.

2 Disponível em: <http://www.aids.gov.br/system/tdf/pub/2014/73/boletim_epidemiologico_hivaids_-_2014.pdf?fil $\mathrm{e}=1$ \&type $=$ node\&id $=73 \&$ force $=1>$. Acesso em: out. 2015.

3 Boletim Epidemiológico n 58/Coordenação Geral da Vigilância Epidemiológica/SMS/PMPA-agosto 2015.

4 Boletim Epidemiológico n 58/Coordenação Geral da Vigilância Epidemiológica/SMS/PMPA-agosto 2015.
} 
pardos” comparativamente aos brancos. Quando verificada a incidência por sexo, nas mulheres "negras/pardas" as taxas são mais que o dobro do que nas mulheres brancas (Boletim epidemiológico, n. 58, agosto de 2015). Em relação à faixa etária, mantém-se o maior percentual de casos na faixa etária de 30 a 39 anos, com média de 33,3\%. Verifica-se aumento nas faixas etárias de 13 a 19 anos e 20 a 29 anos e em indivíduos com mais de 60 anos, independente do sexo, na série histórica de 2007 a $2014 .^{5}$

A mortalidade dos casos de AIDS vem apresentando uma queda gradativa. Porém, Porto Alegre ainda detém taxas elevadas, sendo que apresentou 28,2 casos por 100.000 habitantes; mais do que o dobro do Rio Grande do Sul.

Para quem é docente em escola, importa saber que os jovens são hoje mais vulneráveis a infecção pelo HIV e essa deve ser questão para ser pensada na ação pedagógica. Mas também importa perceber que a epidemia de AIDS, como qualquer outro agravo de saúde, cresce entre os grupos socialmente vulneráveis, que, além dos jovens, são aqueles marcados pela cor negra ou parda, bem como os sujeitos que demonstram orientação sexual diferente da heteronormatividade. Dessa forma, já aqui podemos pensar que uma estratégia pedagógica adequada é abrir espaços para diálogo nas escolas acerca de questões de gênero e sexualidade em conexão com outros marcadores da diferença, como cor da pele, classe social e inserção familiar, de modo a orientar os alunos e alunas.

\section{AÇÕES DA SECRETARIA MUNICIPAL DE SAÚDE}

Para o enfrentamento da epidemia em Porto Alegre, a Área Técnica de DST/AIDS e Hepatites Virais da Secretaria Municipal de Saúde vem implantando diversas estratégias de prevenção, com diferencial para os acessos à testagem rápida e disponibilidade de tratamento para a redução de casos de AIDS. Os Testes Rápidos (TRs) para o HIV/AIDS são excelentes estratégias que possibilitam o acesso da população aos serviços de saúde,

5 Boletim Epidemiológico n 58/Coordenação Geral da Vigilância Epidemiológica/SMS/PMPA-agosto 2015. 
uma vez que são de fácil execução. A leitura e a interpretação são feitas em, no máximo, trinta minutos e não necessitam de estrutura de laboratório. Em Porto Alegre, todas as 141 Unidades Básicas de Saúde já têm profissionais capacitados para a execução de Testes Rápidos para o HIV, sífilis e hepatite $\mathrm{C}$, o que traduz a capilaridade e o alcance dessa ação, atingindo comunidades bastante distantes do eixo central da cidade. Segue aqui outra dica de ação para professores e professoras: a escola deve conhecer e manter uma relação de trabalho com os profissionais da unidade básica de saúde mais próxima, saber informar e referenciar.

O monitoramento dos testes rápidos realizados na Rede de Atenção Primária (RAP) tem por objetivos principais avaliar o quantitativo dos TRs efetuados mensalmente, os quais são inseridos no link criado e padronizado para essa inserção e, principalmente, acompanhar o ingresso dos pacientes diagnosticados reagentes para o vírus HIV nos serviços de saúde, bem como verificar a desejável adesão ao tratamento. Destaca-se, aqui, a importância de incentivar e acompanhar o aumento da realização dos testes rápidos na rede de atenção primária, pois é preconizada a redução da realização dos exames laboratoriais (mais onerosos e demorados) pela atual Gestão em Saúde. Dados apresentados nos últimos Relatórios de Gestão da Secretaria Municipal de Saúde já evidenciam essa tendência ${ }^{6}$. Com relação aos procedimentos realizados pelas Unidades de Saúde após o resultado reagente para o HIV, destacam-se:

- Aconselhamento;

- Solicitação de exames laboratoriais posteriores e complementares pelo médico;

- Agendamento de consulta para apresentação dos exames;

- Análise de valores de referência, que é a avaliação do exame laboratorial;

- Contagem de Células T CD4, que conferem a imunidade celular, comumente chamado apenas de CD4.

6 Disponível em: <http://proweb.procempa.com.br/pmpa/prefpoa/sms/usu_doc/rag_2014.pdf>. Acesso em: out. 2015 . 
Assim, CD4 com resultado maior que 350, o tratamento poderá ser iniciado na Unidade Básica de Saúde de referência do usuário do SUS (unidade mais próxima do local de residência), com a oferta de tratamento (medicamentos antirretrovirais - ARV). Caso o CD4 apresente resultado menor que 350, o paciente será encaminhado aos Serviços de Assistência Especializados (SAEs), para início imediato de tratamento sob os cuidados diretos de infectologista. Esse protocolo é constantemente supervisionado pela Área Técnica DST e Hepatites Virais para o monitoramento dos pacientes com resultados reagentes para o HIV e o rastreamento dos encaminhamentos dos exames laboratoriais de Contagem de Células $\mathrm{T}$ CD4. Utiliza-se o sistema AGHOS (sistema próprio da Secretaria Municipal de Saúde para a marcação de consultas SUS em todo o município) para a confirmação de presença dos pacientes nas primeiras consultas com os infectologistas, em que se dá o início efetivo do tratamento, para casos de CD4 inferior ao valor de referência 350.

Também é feito o trabalho de Educação Continuada das oito Gerências Distritais (espécie de subprefeituras exclusivamente dos serviços de saúde municipais que cobrem todo o território da cidade) através de capacitações e atualizações dos profissionais (médicos, enfermeiros, dentistas, técnicos de enfermagem, técnicos em saúde bucal, etc.), em que se ressalta a importância do acolhimento e acompanhamento dos pacientes soropositivos ao HIV para inserção precoce no tratamento, tão logo haja o diagnóstico por TRs.

\section{GALERA CURTIÇÃO}

Outra estratégia da Área Técnica de DST/AIDS e Hepatites Virais, destinada à comunidade escolar, é o Projeto "Galera Curtição". Tratase de um projeto desenvolvido pelas Secretarias Municipais de Saúde e de Educação de Porto Alegre direcionado aos jovens de 12 a 16 anos de escolas públicas municipais e estaduais de ensino fundamental. É realizada uma gincana cultural entre as escolas, desenvolvida ao longo do ano letivo, cujos objetivos são trabalhar a prevenção ao HIV e doenças sexualmente 
transmissíveis e uso abusivo de álcool e outras drogas, bem como refletir sobre gênero, sexualidade, diversidade sexual, saúde sexual e reprodutiva, racismo, violências e bullying. Esse projeto faz parte do componente II Saúde e Prevenção na Escola (SPE), do Programa Saúde na Escola (PSE).

As tarefas são divulgadas no site próprio e na página no Facebook do projeto e realizadas nas próprias escolas e comunidades. São disponibilizados materiais de apoio para a realização das tarefas, tanto no site como no Portal do Professor. O ponto alto do projeto são os programas de auditório, que acontecem no início do segundo semestre. Além disso, é utilizada a metodologia "teatro-fórum" em visitas às escolas, na qual um ator e uma atriz propõem cenas que estimulam a reflexão e o debate acerca dos diversos temas que compõem o projeto, com a participação dos alunos que se manifestam debatendo as cenas presenciadas. De 2012 a 2015 foram realizadas três edições do Galera Curtição, nas quais participaram diretamente 228 escolas, 15.000 alunos(as) e 840 professores(as). A avaliação do projeto é processual e, no final, os(as) professores(as) e estudantes são convidados a responder um questionário on-line. Nas edições de 2012 e 2014 foram destacados como pontos fortes, entre outros: apoio aos professores, tarefas criativas, ludicidade, linguagem atrativa, estímulo do trabalho coletivo e cooperação e facilitação da reflexão e papo aberto entre professores, alunos e comunidade sobre os temas propostos.

A metodologia utilizada tem propiciado a construção de conhecimentos por meio de uma linguagem jovem, incentivando a participação e o protagonismo juvenil e a atuação dos(as) estudantes como multiplicadores(as) de conhecimentos e estratégias de prevenção do HIV, articuladas com a compreensão dos marcadores sociais das diferenças. $\mathrm{O}$ desafio posto é a inclusão dos temas (gênero, orientação sexual, sexualidade, diversidade, racismo, etc.) no currículo e a apropriação desses por parte dos professores no sentido dessas discussões complementarem, ainda que transversalmente, as rotinas educacionais nas escolas. Dentro do quadro de Educação em Direitos Humanos que estamos trabalhando, sugere-se que as escolas e os serviços de saúde trabalhem em comum acordo no sentido de informar, educar e respeitar a diversidade de orientação sexual e de gênero, 
os pertencimentos religiosos e os valores familiares, mas sem deixar de mostrar que a abordagem em saúde é importante para garantir o acesso seguro dos jovens ao ingresso na vida erótica e sexual.

\section{PROGRAMA NASCER}

Este programa foi instituído pelo Ministério da Saúde através da portaria n ${ }^{\text {o } 2104 / G M ~ d e ~ 19 / 11 / 2002, ~ c o m ~ o ~ o b j e t i v o ~ d e ~ r e d u z i r ~ a ~ t r a n s m i s s a ̃ o ~ v e r t i c a l ~}$ do HIV e a morbimortalidade associada à sífilis congênita. A transmissão vertical do HIV ocorre pela passagem do vírus da mãe para o bebê durante a gestação, durante o parto ou através da amamentação. Sem qualquer ação profilática, o risco de que isso aconteça é de 25\% a 30\%. Se aplicadas todas as medidas preconizadas, a taxa de transmissão vertical do HIV é reduzida para níveis inferiores a $2 \%{ }^{7}$. Visando a essa redução, o município de Porto Alegre vem implementando as ações junto à Rede de Atenção Primária, bem como orientando o cuidado compartilhado das crianças expostas ao vírus HIV. Destacamos o monitoramento da gestante HIV da saída da atenção básica até o pré-natal HIV através de acompanhamento mensal, bem como o acompanhamento de gestante com teste rápido de sífilis reagente.

As crianças recém-nascidas de gestantes soropositivas para o HIV são inscritas no Nascer através de um link e a partir deste cadastramento têm direito ao recebimento mensal de fórmulas lácteas em suas Unidades Básicas de Saúde de referência até um ano de vida, para evitar assim a transmissão do HIV via amamentação. Nesse contexto, a Secretaria Municipal de Saúde trabalha com as instituições - maternidades públicas, privadas e conveniadas - no que se refere à distribuição mensal de insumos para prevenção da transmissão vertical mãe-bebê (antirretrovirais, fórmulas lácteas, testes rápidos e inibidores de lactação). Estima-se que, com essas intervenções, ocorra uma redução na taxa de transmissão vertical do HIV.

O sucesso do programa depende da responsabilidade compartilhada entre os diversos atores participantes, destacando a importância da adesão

7 Ministério da Saúde - Transmissão Vertical do HIV e Sífilis: Estratégias para Redução e Eliminação, 2014. 
das maternidades e, principalmente, das equipes de saúde pela ação direta realizada na prestação de serviços de saúde de qualidade e pela capacidade de promover mudanças sociais nas relações de cuidado entre mães e recém-nascidos. Em Porto Alegre, o programa criou também o Comitê de Transmissão Vertical do HIV/AIDS, coordenado pela Área Técnica DST/ AIDS e Hepatites Virais, que se reúne mensalmente com a presença de representantes das maternidades (públicas, privadas e conveniadas) e de diversos serviços de saúde municipais, em que são debatidos os casos em que, por algum motivo, a gestante não teve acesso à profilaxia adequada e em tempo hábil - o que poderia ter garantido a não infecção pelo HIV ao recém-nascido. Através das apresentações e discussões sobre esses casos, os representantes dos serviços têm subsídios para fortalecer os protocolos de conduta editados pelo Ministério da Saúde, ajudando a estruturar essa rede protetiva às mães gestantes e aos bebês.

Vale aqui ressaltar que a preocupação com a gravidez jovem é outro ponto de atenção para a rede escolar. Dessa forma, estreitando a relação de trabalho com as unidades básicas de saúde, é possível educar e informar sobre o tema. Sabemos como é polêmica a discussão acerca do uso de preservativos tanto para a AIDS quanto para a gravidez, a depender das vinculações familiares e religiosas. A escola deve respeitar esses pertencimentos, mas inserir o cuidado com a gravidez na pauta da Educação em Direitos Humanos e fornecer informações adequadas do ponto de vista científico e técnico.

\section{COMITÊ DE MORTALIDADE POR AIDS DE PORTO ALEGRE}

Para contribuir no enfrentamento da epidemia de HIV/AIDS foi criado, em novembro de 2011, o Comitê de Mortalidade por AIDS de Porto Alegre. O objetivo é estimular a investigação dos óbitos por AIDS no município e contribuir para o conhecimento sobre os indicadores dos óbitos relacionados à AIDS, suas causas e os fatores de risco associados. Esse Comitê também se reúne mensalmente e tem a coordenação da Área Técnica DST AIDS e Hepatites Virais. Como o Comitê de Transmissão 
Vertical, inclui a participação de representantes de diversas instituições de saúde do município, do SUS e privadas. Há também a representação do Ministério da Saúde nas reuniões. A necessidade da criação do comitê se deve ao fato de Porto Alegre ocupar o primeiro lugar no ranking das cidades com maior número de casos e com maior número de óbitos do país.

A análise parcial dos dados, de 2011 até 2015, evidenciou que a maioria dos óbitos é do sexo masculino, com média de idade de 44 anos, grau de escolaridade bastante baixo e usuários de drogas ilícitas, juntamente com álcool e cigarro. A transmissão sexual foi a via mais frequente. Lembramos que Porto Alegre apresenta coeficiente de mortalidade de 23,4 óbitos/100mil habitantes, o mais alto do país. Assim, a criação do Comitê de Mortalidade por AIDS é uma estratégia relevante de investigação e vigilância epidemiológica. O trabalho do Comitê é atuante para poder concluir efetiva e definitivamente sobre essa enorme diferença epidemiológica entre o município de Porto Alegre e todos os demais municípios do Brasil. Através do estudo dos prontuários de pacientes que vieram a óbito por decorrência da AIDS, todos os atores envolvidos analisam e discutem medidas profiláticas que muito provavelmente poderiam ter revertido a condição letal da infecção, desde que tomadas em tempo hábil.

Esse é um tópico em que se verifica a diferença que faz a progressão nos estudos e escolaridade, pois temos uma persistente vinculação entre não conseguir se vincular e proceder ao tratamento, mesmo com a oferta de medicação na rede de saúde, e ter nível baixo de escolaridade. Voltamos ao que se afirmou no início do texto: crianças e jovens cada vez mais vão passar a fase de descoberta das possibilidades eróticas de seus corpos durante a trajetória escolar. E quando professores e professoras insistem na continuidade dos estudos, podem acrescentar que não se estuda apenas para ter uma profissão na vida, mas que existem conexões importantes e positivas entre um elevado grau de estudo e a possibilidade de manter o tratamento a AIDS, como acima se mostrou, mas também com os cuidados em relação ao tabagismo, uso e abuso de álcool e outras drogas, doenças alimentares e do coração. Dessa forma, amplia-se a compreensão de que estudar faz bem 
à vida em geral e não apenas a possibilidade de obtenção de um trabalho ou seguimento de uma carreira profissional.

\section{DESCENTRALIZAÇÃO E ATENDIMENTO COMPARTILHADO DE PACIENTES COM HIV/AIDS EM PORTO ALEGRE}

A descentralização das políticas e ações em HIV/AIDS é um dos maiores desafios na assistência das Pessoas Vivendo com HIV/AIDS (PVHA) no município de Porto Alegre. Uma das estratégias para o enfrentamento da epidemia de HIV/AIDS utilizada pela atual gestão da Secretaria Municipal de Saúde é a educação continuada em manejo clínico como dispositivo para a descentralização dos pacientes assintomáticos e estáveis na Atenção Primária à Saúde (APS). O objetivo dessa capacitação é sensibilizar os médicos da rede de atenção à saúde do Município de Porto Alegre para o manejo clínico de pessoas vivendo com HIV/AIDS. A capacitação é dividida em duas etapas: a primeira etapa desenvolve-se através de aulas expositivas ministradas por médicos infectologistas e médicos treinados em atendimento de pessoas vivendo com HIV/AIDS e estudos dirigidos em manejo clínico. Na segunda etapa, são realizados atendimentos de pacientes em Serviços de Assistência Especializada (SAEs) e APS. Já foram capacitados 114 profissionais médicos (38,38\%) de 97 serviços da atenção primária, representando 46,63\% dos serviços capacitados, sendo eles referentes a: 26 unidades básicas de saúde; um consultório de rua; uma equipe de saúde indígena e 69 unidades básicas de saúde da família.

O trabalho realizado até setembro de 2015 atingiu quase a metade dos serviços de rede de atenção primária em saúde, faltando ainda 53,37\%. Essa primeira metade, entretanto, já possibilitou o início da descentralização do atendimento sob matriciamento. Como esse processo de capacitação é permanente, a etapa de pós-manejo clínico já está realizando round de estudos de caso nas oito gerências distritais e matriciamento em serviço, visando ao suporte na rede básica através de reflexões sobre a realidade local e tensionamento nas novas formas de processo de trabalho inseridos dentro 
da linha de cuidado estabelecida pela Cooperação Interfederativa; ou seja, os esforços conjuntos da Secretaria Municipal de Saúde Porto Alegre, da Secretaria Estadual de Saúde e do Ministério da Saúde, estabelecidos para gerenciar a situação da epidemia na região metropolitana de Porto Alegre. De modo concreto, isso significa que em cada unidade básica de saúde teremos profissionais capacitados a cuidar de pessoas vivendo com AIDS e com isso teremos também, mais próximos das escolas, unidades de saúde com profissionais qualificados para conversar sobre doenças sexualmente transmissíveis, modos de infecção e estratégias de cuidado.

\section{PROTOCOLO DE AGENDAMENTO E REGULAÇÃO DE PACIENTES COM DOENÇAS INFECCIOSAS}

O protocolo descreve os critérios estabelecidos para a regulação de pacientes adultos com Doenças Infecciosas e Parasitárias da rede de saúde do Município de Porto Alegre. Para a maioria dos agravos, o encaminhamento é direcionado para infectologia adulto, infectologia HIV adulto e pediátrico, gastro hepatites virais e lipodistrofia, efeito colateral da terapia antirretroviral que altera a distribuição de gordura do organismo com concentração de gordura na barriga, costas, pescoço e nuca e perda de gordura nos braços, pernas, nádegas e face e que acarreta também alterações metabólicas como o aumento do colesterol e dos triglicérides, elevando o risco de problemas cardíacos.

No contexto da infecção pelo HIV/AIDS, respeitando-se a linha de cuidado em implantação pela Área Técnica quando o diagnóstico é feito na rede de Atenção Primária em Saúde (APS), os pacientes acometidos por HIV/AIDS (PVHA pessoas vivendo com HIV/AIDS) poderão ter seu acompanhamento feito pela própria unidade na APS. Além disso, os pacientes considerados estáveis, pertencentes aos Serviços de Assistência Especializada (SAEs), ambulatórios ou enfermarias de hospitais podem ter seu atendimento compartilhado na APS, quer seja para o tratamento de outras enfermidades ou para acompanhamento de seu tratamento antirretroviral. 
Quando há necessidade de exames mais complexos, em nível ambulatorial, dada a complexidade do paciente ou por não preencher critérios para atendimento na rede de atenção primária em saúde, a unidade básica de saúde deverá solicitar agendamento para a subespecialidade infectologia HIV adulto ou pediátrico, se for o caso. Os critérios de alta prioridade HIV/AIDS também são apresentados nesse documento. Pacientes com lipodistrofia podem ser agendados para lipodistrofia HIV para avaliação de tratamento cirúrgico. Pacientes com HIV/AIDS e que apresentam outras Doenças Sexualmente Transmissíveis (DSTs), como sífilis e uretrites, quando indicada abordagem etiológica, devem ser encaminhados ao especialista dermatologista.

Pacientes com hepatites virais são encaminhados para a subespecialidade gastro-hepatites virais; pacientes coinfectados com HIV e hepatites poderão também ser acompanhados para início de tratamento das hepatites no SAE Hepatites. Para que o agendamento ocorra apropriadamente é fundamental que a atenção primária em saúde, feita em unidade básica de saúde ou em unidade de saúde da família, solicite inserção dos pacientes no AGHOS a partir do CID conforme os critérios, observações e CIDs apresentados dentro do documento.

A otimização da assistência inclui a ideia do "paciente certo no lugar certo”, ou seja, a utilização da rede de saúde pelo usuário conforme o nível de complexidade necessário para a sua condição de saúde no momento. Desse modo, é fundamental a clareza tanto das necessidades de saúde relacionadas à prevenção e ao tratamento das doenças infecciosas mais prevalentes no município, das particularidades dos pacientes, assim como da logística, dos fluxos, dos recursos humanos e materiais de toda a rede. O protocolo apresenta as necessidades e a rede disponível para o atendimento e para a atenção dessas necessidades das pessoas acometidas por doenças infecciosas do município. Em um segundo momento, os fluxos e encaminhamentos de agendamentos e de regulação desses pacientes são detalhados por especialidade e subespecialidade, por nível de complexidade e por local de atendimento. 

DIVERSIDADE

Apesar da sistemática omissão dos boletins epidemiológicos brasileiros, é sabido que a população de travestis e transexuais apresenta as maiores taxas de incidência de HIV e de mortalidade a ele relacionadas. No banco de dados em Porto Alegre, há a limitação formal da impossibilidade de categorizar essa população no sistema de notificação. Muito provavelmente essas populações podem estar enquadradas na categoria HSHs (homens que fazem sexo com homens), mas até o presente não temos dados referentes a elas. A pesquisa de Magnor Müller (2007) aponta fatores como vulnerabilidade, exclusão social, desinformação quanto à importância da prevenção e, em casos reagentes para o HIV, a quase nula adesão ao tratamento, quando não a sua completa interrupção, devido a dura rotina de travestis e transexuais na relação com o SUS municipal. Nesse quadro adverso, em que a maioria das travestis enfrenta as ruas e suas violências (clientes, comunidade no entorno, policiais), cotidianamente para a prática da prostituição, como única forma de sobrevivência, essa vulnerabilidade é associada à maior infecção pelo HIV.

Para atender essa população nas suas condições singulares, foi criado, em 2014, em Porto Alegre, o projeto "Garantia de Acesso - atendimento à diversidade”, uma capacitação no próprio serviço, em que são convocados todos os trabalhadores da unidade (porteiros, servidores de limpeza, auxiliares de enfermagem, técnicos, enfermeiros, dentistas, médicos) para a atividade. Trata-se de uma experiência inédita no contexto nacional, em que uma atriz encarna uma travesti que busca uma unidade básica de saúde para seu fictício atendimento. A unidade está sem atendimentos externos naquele horário, pois aguarda uma capacitação a ser realizada pela Área Técnica DST/AIDS. A "travesti" - na realidade, uma performance profissional da atriz - tenta acessar a unidade reclamando alguma moléstia (náuseas, vômito, coceiras, febre, diarreia) para buscar atendimento. Ressalte-se que sempre técnicos da área técnica acompanham essa performance, observando à distância, nas imediações da unidade, sem qualquer intervenção enquanto ocorre a cena. Passados em média 15 minutos, há sempre duas situações: ou a "travesti” é 
acolhida, tem ouvidas as suas queixas e recebe um encaminhamento, ainda que seja para voltar em outro dia, ou tem negado o atendimento, com a justificativa que não há profissionais disponíveis para o acolhimento naquele momento em razão da atividade de capacitação. Após o impacto da presença da "travesti" na unidade e o sucesso ou não de busca por atendimento, os técnicos entram na unidade, se apresentam enquanto tais e, de pronto, convidam a "travesti" para acompanhá-los na capacitação. A partir daí, ocorre uma apresentação formal entre todos os presentes, inclusive da "travesti", e começa uma discussão de cerca de uma hora e meia sobre as dificuldades do atendimento a travestis e transexuais no SUS municipal, em que, invariavelmente são ouvidos relatos quanto à dificuldade de uso do nome social por parte dos servidores, desconhecimento da portaria municipal que institui tal procedimento, ideias equivocadas quanto a gênero e orientação sexual; momentos em que muitas vezes preconceitos, nem sempre tão velados, praticados contra essa população aparecem.

Após esse debate, já no final da capacitação, a atriz é convidada a se "desmontar" e se apresenta como mulher e atriz, retirando cuidadosamente sua peruca e maquiagem. Mediante a surpresa da revelação, todos os servidores comentam sobre a "pegadinha". Nesses momentos, os técnicos da área técnica reforçam os alarmantes índices do HIV em nossa cidade, com vulnerabilidade maior justamente na população de travestis e transexuais, que sofrem com o despreparo dos serviços em acolhêlas, tratá-las e orientá-las em situações que dizem respeito a sua saúde, suas particularidades e os direitos de serem acolhidas e bem tratadas como qualquer outro usuário do SUS.

A estratégia de ação acima mostra como são efetivos os recursos da dramatização e do teatro, que podem também ser utilizados nas escolas para mostrar as difíceis condições de convívio com as diferenças de gênero e sexualidade. 


\section{CRUZAMENTOS ENTRE SAÚDE, EDUCAÇÃO E DIREITOS HUMANOS}

A escola deve se valer das parcerias com as unidades básicas de saúde, com os programas de saúde que existem em sua localidade, para auxiliar no processo de informação e educação acerca das doenças sexualmente transmissíveis. Sabemos dos conflitos entre as orientações familiares, orientações das religiões e orientações da área da saúde em particular nessas doenças que são resultado da vida sexual. Entretanto, de modo respeitoso e em sintonia com os conhecimentos científicos e com os referenciais de direitos humanos, a escola deve se afirmar como um local para conhecimento e aconselhamento. Vale lembrar que a escola, como também o posto de saúde, são espaços públicos, e sua tarefa é ensinar o respeito pela diversidade de gênero e de sexualidade, bem como assegurar que todos tenham acesso ao cuidado em saúde. Certamente a escola sozinha irá enfrentar muitos problemas para abordar esses temas, mas em parceria com os órgãos de saúde pública, bem como com as estruturas de direitos humanos, como unidades do ministério público, ela poderá se tornar um local de referência para a informação e educação em saúde sexual.

\section{REFERÊNCIAS}

BRASIL. Departamento de DST, Aids e Hepatites Virais. Boletim Epidemiológico de Hepatites Virais - 2014. Disponível em: < http:/www.aids.gov.br/system/tdf/pub/2014/73/boletim_epidemiologico_hivaids_-_2014.pdf?file $=1 \&$ type $=$ node\&id $=73 \&$ force $=1>$. Acesso em: out. 2015.

BRASIL. Departamento de DST, Aids e Hepatites Virais. Boletim Epidemiológico de Hepatites Virais - 2015. Disponível em: <http://www.aids.gov.br/system/tdf/pub/2015/90/boletim_hepatites_2015.pdf?file $=1 \&$ type $=$ node\&id $=90 \&$ force $=1>$. Acesso em: out. 2015 .

BRASIL. Prefeitura Municipal de Porto Alegre. Plano de Enfrentamento da epidemia de HIV/AIDS em Porto Alegre. Secretaria Municipal de Saúde e Programa das Nações Unidas para o Desenvolvimento/PNUD-Brasil, 2013.

MÜLLER, M. I. Os médicos nunca me tocaram um dedo! Eu cansei daquele posto!: a percepção das travestis quanto ao atendimento em saúde. Porto Alegre: Universidade Federal do Rio Grande do Sul, 2007. 


\section{RESUMOS DOS TRABALHOS FINAIS DOS ALUNOS}

\section{POLO: PORTO ALEGRE}

Aluno(a): Gilberto Puntel

Escola: Escola Estadual Nossa Senhora de Fátima

\section{Título do trabalho: Caminhos a percorrer}

Resumo:

A atividade planejada foi a organização de materiais didáticos para tradução ao sistema do alfabeto braile e sensibilização das pessoas à necessidade de sinalizadores horizontais no prédio da escola, bem como a alteração da aclividade da rampa que dá acesso ao segundo piso. Essa ação foi escolhida em razão de a escola possuir um aluno cego e não dispor de material didático traduzido para o braile e pelas condições de acessibilidade da escola, pois a mesma possui muitos degraus com rampas pouco acessíveis. O principal objetivo foi a obtenção de material traduzido para o braile; objetivo este já atingido. No entanto, a situação de acessibilidade e sinalização dependerá do investimento do governo do estado, para o qual se aguarda disponibilização de recursos. 
Aluno(a): laraci de Souza Silva

Escola: Escola Municipal de Ensino Fundamental Nossa Sra. do Carmo

\section{Título do trabalho: As linguagens como instrumento desencadeador do tema da diferença socioeconômica em uma turma de jardim B - João e Maria}

Resumo:

Vivemos novos tempos nos quais identificamos no cotidiano escolar "uma criança de diferentes infâncias" (Dornelles, 2007) e, talvez, o mais interessante seja saber que esses sujeitos surgiram na década de 1990 com a era tecnológica, a mídia e outros fatores socioculturais. Diante do exposto, vamos nos ater à infância pobre na periferia, partindo do marcador social de diferença socioeconômica em vista da nossa realidade e de termos vivenciado uma situação de discriminação dessa natureza no nosso grupo de crianças da educação infantil (crianças de uma turma de Jardim B, do turno vespertino, da EMEF Nossa Senhora do Carmo, localizada na periferia de Porto Alegre). É verdade que o tema em questão não é, infelizmente, novidade para quem convive nesse contexto. Entretanto, pretendemos aqui dar a devida visibilidade ao assunto, pois temos nos preocupado com uma educação conteudista há muito tempo e, apenas há cerca de 20 anos, estamos revendo nossos conceitos, nossa prática pedagógica e nossos valores na educação, como podemos constatar no texto de lei da LDB - Lei 9394/ 96 - Lei de Diretrizes e Bases da Educação Nacional (MEC), quando esta menciona, em seu Art. $2^{\circ}$ a finalidade da educação nacional: "A educação, dever da família e do Estado, inspirada nos princípios de liberdade e nos ideais de solidariedade humana, tem por finalidade o pleno desenvolvimento do educando, seu preparo para o exercício da cidadania e sua qualificação para o trabalho". Para tanto, nos valeremos das teorias de Freire, Dornelles, Sarmento, Parode, Gardner e Goleman, a fim de darmos fundamentação teórica ao processo de execução da proposta; uma proposta que será 
articulada progressivamente com as crianças, considerando-as em sua singularidade e subjetividade enquanto produtoras de cultura (Sarmento, 2007), logo, capazes de atuarem socialmente pelos seus direitos.

Aluno(a): Jairo Adilson Stangherlin

Escola: Escola Municipal de Ensino Fundamental Victor Issler

\section{Título do trabalho: $\mathbf{O}$ direito de jogar futebol}

Resumo:

Introdução: André é um menino que nasceu com agenesia de pés e mãos, mas adora jogar futebol, tendo treinado e participado de jogos nos últimos anos. Á medida que cresce, aumentam as dificuldades e diminui sua participação, uma vez que o seu direito de jogar vai sendo burlado pelo crescimento das diferenças entre ele e os colegas. Assim propusemos fazer a mediação para tornar sua participação mais justa.

Objetivos:

- Melhorar a participação de André nos treinos e jogos;

- Usar a mediação para resolver os conflitos no jogo.

Metodologia: A metodologia usada será a mediação de conflitos.

Referencial teórico: $\mathrm{O}$ esporte rompe várias barreiras para a pessoa com deficiência. É uma forma de reabilitação física e psicológica que, além de ajudar a vencer o preconceito, mostra à sociedade que sua vida pode ser ativa, competitiva e autônoma.

Desenvolvimento: a proposta de intervenção usou a mediação para tornar as adaptações feitas nos jogos mais justas para a participação do André nos jogos e treinos.

Resultados obtidos: Ao longo dos treinos os outros alunos agem com André como um jogador de menor habilidade, não passando a bola. Somente com a mediação e intervenção, eles passam a bola ou deixam que cobre faltas, pois, na ânsia de vencer o jogo, eles agem sem pensar nos outros. 
Conclusão: A vida do deficiente físico no futebol é complicada, pois a visão que impera é de vencer a qualquer custo e não a do jogar com o outro; dessa forma as diferenças vão aumentando e o diferente vai sendo excluído do sistema.

Referência: Declaração Universal dos Direitos Humanos; Cartilha IBDD dos direitos da pessoa com deficiência.

Aluno(a): Leonardo Rocha de Almeida

Escola: Escola Municipal de Ensino Fundamental Inácio de Quadros (Guaíba/RS)

\section{Título do trabalho: $\mathbf{O}$ gênero nas brincadeiras infantis: as músicas de pular corda}

\section{Resumo:}

Durante minhas atividades junto às turmas de Educação Infantil e Ciclo de Alfabetização, tenho me deparado com a recorrência do debate sobre gênero. Isso se dá pelo fato de eu ser visto pela sociedade como homem e, a partir dessa visão, um "ser estranho" às classes que trabalham com crianças pequenas. Dessa forma, sempre chamou atenção das crianças quando eu brincava com elas das mais diversas atividades, como cirandas, pular corda, dançar, etc. A partir da experiência, fui percebendo como as brincadeiras infantis carregam estereótipos de gênero e escolhi como atividade final do curso trabalhar com o pular corda. Foi realizado junto às crianças do $1^{\circ}$ ano do ensino fundamental da turma em que sou docente um debate sobre brincadeiras que estes consideravam de meninos e brincadeiras que eles consideravam de meninas. Partimos das falas e fomos brincar de pular corda, a brincadeira mais votada pelos alunos. Cantamos as músicas e eu, enquanto professor, percebi o caráter domesticador das mesmas por incentivar o casamento e a escolha de namorados para as meninas. Durante o tempo de brincadeira, outra turma se juntou para pular corda e os alunos puderam interagir. Ao final, voltamos para a sala e discutimos novamente sobre o 
que havia acontecido, se os alunos haviam gostado e se algum menino tinha virado menina. Concluímos que não era a brincadeira, ou o que a gente gosta de fazer, que nos transforma em menino ou menina. Realizamos assim uma atividade voltada para a alfabetização como forma de síntese do trabalho para expor aos pais nos corredores da escola. Enquanto professor, percebi a importância de trazer situações cotidianas a uma nova perspectiva, como foi o caso de pensar essas músicas que estão tão inseridas no cotidiano escolar, podendo assim problematizar junto aos educandos e proporcionar novas possibilidades de interação no mundo.

Aluno(a): Leticia Svoboda

Escola: Escola Estadual Gen. Daltro Filho

\section{Título do trabalho: Somos todos iguais nas diferenças}

Resumo:

Realizei a intervenção com uma turma de 16 crianças de 7 a 8 anos do $2^{\circ}$ ano do ensino fundamental de uma escola pública da rede estadual de Porto Alegre. O objetivo era sensibilizar as crianças sobre as diferenças, apresentando através da literatura infantil a realidade das pessoas com necessidades especiais; incentivando um novo olhar sobre a diversidade que promova o resgate da cidadania, da solidariedade e da inclusão, através da aceitação pessoal e social das pessoas, bem como o respeito às diferenças e o senso de justiça através do diálogo. Iniciei com a leitura Na minha escola todo mundo é igual e fiz duas perguntas: "O que vocês acham que é ser igual?" e “O que nos falou a história?”. Várias respostas surgiram. Muitas propostas puderam ser realizadas para sensibilizar as crianças, como painel com recortes mostrando as diferenças entre as pessoas, com olhos vendados tentar descobrir objetos através do tato, falar sobre LIBRAS e braile, entre outras. Estou satisfeita com o desenvolvimento do projeto até aqui, pois percebo que as crianças são abertas a novas experiências e não fazem distinções entre si mesmas. Aceitar as diferenças é primordial para estabelecer a convivência 
212 e o desenvolvimento das relações humanas, afinal somos todos diferentes uns dos outros, mas com os mesmos direitos.

Aluno(a): Olga Madalena Boelter

Escola: Escola Estadual de Ensino Fundamental Dr. Oswaldo Aranha

\section{Título do trabalho: Racismo? Preconceito? Que feio!}

Resumo:

Como professora de História, constantemente trabalho temas relacionados à história da África e dos direitos humanos. A proposta de intervenção pedagógica partiu de uma situação de violação de direitos humanos, quando um aluno se referiu a uma colega com uma palavra ofensiva e racista. Iniciando os trabalhos com os vídeos do projeto A Cor da Cultura, os alunos foram provocados à seguinte reflexão: se todos somos iguais, por que o preconceito? E como cor, cada um tem a sua, foram convidados a colorir os desenhos de menino/menina de acordo com seu tom de pele, utilizando gizes de cera da coleção Pintkor (Korale/Uniafro), com a intenção de desconstruir a dicotomia preto/branco. A ideia é seguir inserindo o tema dentro da disciplina, culminando em uma saída de campo, ao final do ano, no "Percurso Territórios Negros: afro-brasileiros em Porto Alegre".

Aluno(a): Priscila Vieira Bastos

Escola: Escola Estadual de Ensino Fundamental Vila Jardim Renascença

\section{Título do trabalho: Cultura do estupro}

Resumo:

Busquei abordar primeiramente o que os alunos entendiam por estupro, apresentei o conceito e posteriormente trabalhei um pouco a Lei 
Maria da Penha. Após, realizei uma reflexão com os alunos a respeito dos rótulos sociais que são impostos às mulheres ao longo das décadas, em situações como a utilização de bebida alcoólica, uso de minissaia ou roupas justas, batons de tons fortes, etc. Contudo, o mais impressionante foi que tanto os meninos como as meninas acreditam que a mulher que bebe não tem direito algum sobre seu próprio corpo, diferente do homem; mesmo com pouca idade os educandos demonstraram um posicionamento voltado para o patriarcalismo. Obviamente suas identidades estão em construção e no presente momento o que é passado como correto pela família é o que lhes parece ser a única via de pensamento. Observei que as meninas achavam realmente que o batom vermelho provoca os meninos a as beijarem e que se isso acontecer de modo forçado é considerado normal, já que elas os instigam a este fato. Por fim, procurei fazer com que eles refletissem que todas as mulheres podem sair para a rua de minissaia ou com saia longa e que elas devem ser tratadas da mesma forma respeitosa, pois não é uma vestimenta ou maquiagem que pode "rotular alguém”.

Aluno(a): Taís Palácios Fraga Uema

Escola: Escola Estadual de Ensino Médio Orieta

\section{Título do trabalho: Escola, local de aprendizagens e conflitos}

Resumo:

O curso de Direitos Humanos na Educação me deu subsídios para trabalhar questões que envolviam etnia e preconceito em sala de aula. Procurei desenvolver atividades em que os alunos pudessem se perceber como diferentes na cor e nas características físicas, mas que isso não os diferenciava nos seus direitos e obrigações. Por serem alunos do $4^{\circ}$ ano do ensino fundamental, busquei através do lúdico desenvolver nesses alunos uma visão social humana e o respeito ao próximo e à diversidade. Para desenvolver este trabalho, utilizei os recursos que a escola oferecia, como vídeos, músicas e textos, o que facilitou na hora de prender a atenção dos 
alunos. Ao final de cada aula fazíamos a "roda da reflexão", quando eles ficavam livres para falar se já haviam sofrido algum tipo de preconceito, como reagiram e qual a atitude que tomariam se fosse hoje. A partir dessas atividades, os alunos iniciaram um processo de conscientização sobre seus atos, direitos, deveres e respeito ao próximo.

Aluno(a): Vania Paiva Golgo

Escola: Escola Estadual de Ensino Fundamental Aurélio Reis

\section{Título do trabalho: Xô Preconceito! Racismo, tô fora!}

\section{Resumo:}

Apresento uma proposta de intervenção em algumas das situações nas quais diagnostiquei uma possível violação dos direitos humanos. O preconceito, pertinente ao racismo e às formas ofensivas das brincadeiras racistas que os alunos utilizam no ambiente escolar, foi o motivo para a escolha de uma prática do diálogo e do perguntar restaurativo. São situações conflituosas vivenciadas no dia a dia, depreciando o funcionamento de toda uma rotina escolar. Sendo assim, essa abordagem objetiva trabalhar com práticas restaurativas no gerenciamento desses conflitos. Nessa perspectiva, buscaremos uma abordagem por meio de uma sequência de diálogos e intervenções no aprender a respeitar e no exercício da reflexão e da cooperação. Apresentamos o perguntar restaurativo, elaborado no Guia Prático para Educadores (2014): o que aconteceu? Quem foi afetado ou sofreu algum dano? Como você acha que a vítima se sente? Quais as soluções que podem beneficiar cada um dos envolvidos? A intervenção desenvolvida na escola foi bastante complicada, pois estávamos entrando em férias e precisaríamos de mais tempo e espaço físico, além de pessoal capacitado para o desenvolvimento da proposta. Logo, as dificuldades foram muitas. Acrescenta-se a isso que práticas restaurativas aplicadas no contexto escolar guiam as pessoas para lidar com conflitos de forma diferenciada e comprometida, levando o aluno à reflexão, responsabilização e restauração 
dos danos causados. Sendo assim, destacaria Santos (2014, p. 2) quando aborda a respeito dos conflitos: "Um conflito bem administrado pode servir para modificar comportamentos, tanto dos envolvidos, como de outros atores ao redor deles". Vale a reflexão!

\section{POLO: SANTO ANTÔNIO DA PATRULHA}

Aluno(a): Ariana Souza Cavalheiro

Escola: Escola Municipal de Ensino Fundamental Michigan

\section{Título do trabalho: Discussões acerca das relações étnico raciais $\mathrm{e}$ a diversidade com o público infantil}

Resumo:

O objetivo deste relatório é contar um pouco das atividades que se efetivaram na escola onde trabalho sobre os temas raça/cor/etnia, a fim de intervir sobre algumas práticas de racismo, violência, discriminação e preconceito que acontecem dentro da escola. A relevância dessa intervenção se dá pela falta de discussão e pelas atitudes que afirmam o preconceito com as crianças negras, seja pela cor de sua pele, pelo seu cabelo ou pela sua condição social. Dialogar e discutir sobre a importância de tais ações afirmativas trabalhadas com o público infantil acerca da diversidade, suas etnias e as origens afro-brasileiras torna-se extremamente importante para que elas percebam e respeitem a singularidade de cada um. Essa intervenção aconteceu a partiu de uma pesquisa apresentada pela mídia no mês de novembro de 2013, a qual apresentava a concepção das crianças em faixa etária entre 4 e 5 anos, sobre as bonecas "branca e negra". Nesse sentido, irei deter-me em apresentar algumas discussões que estão entrelaçadas a esse discurso, destacando alguns pontos que nos levam desde pequenos a 
assumir outra identidade e ao não reconhecimento de uma identidade negra. Uma verdadeira chuva de notícias, informações e matérias são realizadas somente no mês de novembro, mês em que se comemora a Consciência Negra. Assim, as discussões que precisam estar dentro do espaço da escola e da sala de aula só aparecem quando esse mês se aproxima, esquecendo que milhares de crianças, professores(as) e funcionários(as) negros fazem parte desse ambiente. Mas, entre essas inúmeras matérias, a que mais me intrigou foi uma pesquisa realizada com crianças, de faixa etária entre 4 e 5 anos, da educação infantil de uma escola de periferia da região de Porto Alegre. Vale pensar que nesta idade em que se encontram as crianças elas não possuem um contato maior com discussões, mesmo que esses assuntos possam ser tratados através de projetos. Então, penso que a proposta de se trabalhar e apresentar uma boneca negra para as crianças em fase pré-escolar irá auxiliar na construção da sua identidade enquanto afrodescendente. É como se vissem em um espelho sua imagem refletida, onde suas características também fossem representadas por esse brinquedo tão cobiçado.

Aluno(a): Claudia Emi Yoshida

Escola: Colégio Estadual Deoclécio Ferrugem

\section{Título do trabalho: A Iniciação Científica como estratégia de intervenção pedagógica}

Resumo:

Como única escola de ensino médio da cidade, atendemos a todos os jovens de diferentes classes sociais. Aqueles que vão para o turno da noite precisam trabalhar, diferente dos que estudam de manhã e, aparentemente, têm maior apoio da família nos estudos e não trabalham; por isso, há o entendimento de que à noite estudam os jovens de menor poder aquisitivo. É unânime a fala dos professores de que o turno da manhã é completamente diferente do da noite. Dizem que os alunos da noite não têm interesse pelas atividades, não fazem os trabalhos de pesquisa nem os estudos em casa. Não 
são observadas, no entanto, as dificuldades que esses jovens enfrentam, tanto sociais, como psicológicas ou familiares. Quando as atividades não fazem sentido para a realidade do estudante, acontece o desinteresse. Isso indica que eles têm deixado de ser atendidos nas suas necessidades e especificidades por serem diferentes daquele ideal de estudante do imaginário da maioria dos professores. É importante buscarmos alternativas pedagógicas que visem atendê-los quando pensamos que a escola é para todos. A escola precisa se dar conta de que temos grupos heterogêneos e que as metodologias não funcionam quando padronizadas. Trabalhar com Iniciação Científica, em que existe investigação de uma curiosidade genuína do aluno, pode fazer com que ele se interesse pelas atividades, porque observará que seu trabalho responderá a uma questão que ele considera relevante. Isso pode movê-lo de forma a se organizar, desenvolver senso crítico e autonomia, participar mais das aulas, ter interesse em aprender, trocar experiências com os colegas e professores, responder às solicitações dos professores e tornar-se, de fato, um estudante. O resultado do trabalho com esses jovens não foi diferente, porém em proporção menor do que com os do turno da manhã. Eles se interessaram em desenvolver a atividade proposta e se envolveram com o trabalho satisfatoriamente, confirmando a teoria de que atividades específicas que visem atender às especificidades dessa juventude são eficientes para favorecer o processo de ensino e aprendizagem.

Aluno(a): Claudia Plá Nogueira

Escola: Escola Municipal de Ensino Fundamental Getúlio Vargas

\section{Título do trabalho: Somos todos diferentes}

\section{Resumo:}

Todos os caminhos da educação levam ao trabalho com a diversidade e, para tal, precisamos desmitificar esse universo de diversidade e construir valores junto aos alunos. Pretendeu-se, através deste estudo, trazer o debate sobre gênero à escola, propondo a ampliação dos horizontes dos alunos e 
proporcionando a discussão e o entendimento de que todos somos diferentes, buscando o relacionamento dos alunos livres de atitudes e pensamentos preconceituosos. Buscando conhecer o grupo de alunos e tencionar a problemática entre os alunos da turma 53 da Escola Municipal de Ensino Fundamental Getúlio Vargas, em Cachoeirinha, se iniciou o trabalho com a leitura do livro Chega de rosa, da autora Nathalie Hense. Após, foi solicitado que os alunos fizessem um reconto oral da história, quando se encorajou a participação de todos, colocando aspectos que mais lhe chamaram a atenção. Em seguida, foi feita a brincadeira do "saco surpresa": cada um deveria retirar do saco um brinquedo sem poder escolher, ler a pergunta que estava colada ao mesmo e respondê-la com a ajuda dos colegas. Todas as perguntas tinham um cunho desafiador no sentido de fazê-los refletir sobre suas concepções e problematizar cada situação exposta. Todas as conclusões finais dos alunos, a partir de cada questão, foram anotadas em um grande cartaz que simbolizou a concepção dos alunos frente à relação proposta. A partir da atividade com a turma, foi possível sugerir à escola e à professora que incorporem o debate das questões abordadas no trabalho durante as aulas, assim como atividades que estimulem a cooperação e a colaboração entre os alunos. Afinal, a fim de que possamos desenvolver uma cultura democrática e colaborativa, temos que viabilizar a construção de novas relações entre homens e mulheres através dos princípios de justiça e igualdade entre todos.

Aluno(a): Janaina Peixoto de Freitas e José Carlos Ferrari Júnior

Escola: Escola Municipal de Ensino Fundamental São Pedro

\section{Título do trabalho: 0 Rio Grande do Sul também é terra de batuque, griô, turbante e Lupicinio Rodrigues}

Resumo:

No Brasil, a educação antirracista é direito de todos; porém, como se dá esse direito é uma outra história bem diferente. No estado do Rio Grande 
do Sul, a situação é a mesma. Nesse sentido, junto a uma turma de $5^{\circ}$ ano da Escola Municipal de Ensino Fundamental São Pedro, promovemos uma oficina que suscitasse questionamentos referentes à invisibilidade do negro, materializado pelos livros didáticos de Geografia e História do Rio Grande do Sul. O objetivo da realização dessa atividade foi resgatar e valorizar o papel do negro na formação histórica, espacial, social, econômica e cultural do estado e discutir com os alunos o que vem a ser racismo institucional. Dentro dessa perspectiva realizamos três encontros, perpassando desde a relação Brasil X África, o papel do negro na formação econômica, social e cultural do Estado, a visibilidade de personalidades, festas e aspectos culturais relevantes para a história do Estado até a reflexão de como o negro é tratado nos livros didáticos. O planejamento da atividade aconteceu nos momentos destinados ao planejamento individual de cada professor, impossibilitando, às vezes, que professores pudessem discutir em conjunto detalhes da oficina, sendo, sem dúvida, a principal dificuldade a falta de tempo para planejar as atividades. Porém, os resultados foram bem interessantes. Os alunos desenvolveram reflexões bastante instigantes em relação ao cotidiano urbano, como questionamentos em relação à forma como os livros mostram os imigrantes europeus em festas e os negros não, sabendo, por exemplo, que só em Porto Alegre temos festas importantes como a de Ogum no bairro Ipanema, de Iemanjá no Lago Guaíba e o Carnaval e nada disso é relatado nos livros. Penso que foi bem proveitosa a atividade; para o segundo semestre, iremos pensá-la e qualificá-la com professores de História, Geografia, Língua Portuguesa, Artes e Educação Física, nas turmas dos $6^{\circ}$ anos, nas quais temos várias situações de práticas de racismos. 
Aluno(a): Karen Graziela Weber Machado

Escola: Escola Municipal de Ensino Fundamental Arthur Ostermann

\section{Título do trabalho: A inclusão escolar de alunos com deficiências}

\section{Resumo:}

O presente estudo refere-se a uma proposta de intervenção desenvolvida em uma turma de $4^{\circ}$ ano do ensino fundamental de uma escola da Rede Pública Municipal de São Leopoldo, devido ao fato do grupo de alunos isolarem uma colega deficiente física no momento do desenvolvimento das atividades propostas. A Constituição Federal diz no Art. 205 que "[A] educação, direito de todos e dever do Estado e da família, será promovida e incentivada com a colaboração da sociedade, visando ao pleno desenvolvimento da pessoa, seu preparo para o exercício da cidadania e sua qualificação para o trabalho”. Segundo Santos $(2015$, p. 1), “[...] a educação é compreendida hoje como um direito humano universal, motivo pelo qual o acesso à escolaridade é um dever de todos os Estados de oferecerem às suas populações". Por outro lado, os educadores têm se deparado com mudanças no perfil do alunado, pois é cada vez mais frequente a presença de estudantes que destoam dos demais em razão de algum marcador social de diferença. Foram trabalhadas na aula questões relacionadas às deficiências, de forma a proporcionar a reflexão dos alunos sobre a importância da inclusão de pessoas com deficiência na escola e de respeitar as diferenças, sendo que a pluralidade favorece que aprendamos uns com os outros independentemente das nossas características peculiares. Nessa aula os educandos demonstraram-se empenhados e motivados em realizar as tarefas solicitadas. Esses reconheceram, através de reflexões individuais e coletivas, a importância de todos os alunos valorizarem e respeitarem as diferenças existentes entre eles para terem uma boa convivência e participarem das atividades propostas, sendo esse um direito de cada um deles. Portanto, a escola deve contribuir significativamente para o desenvolvimento integral 
de cada educando, que precisa ser orientado a respeitar as diferenças existentes entre as pessoas, contribuindo assim para uma sociedade digna e democrática.

Aluno(a): Luciane de Oliveira Machado

Escola: Escola Municipal de Ensino Fundamental Judith Macedo de Araújo

\section{Título do trabalho: Direitos humanos e as relações étnico- raciais - Dia internacional contra a discriminação racial}

Resumo:

A atual sociedade e a escola passam por vários processos de discriminação racial. Esse tema e as situações vivenciadas muitas vezes não são colocados para discussão na sociedade, tampouco pela escola; porém, a turma B22 da Escola Municipal de Ensino Fundamental Judith Macedo de Araújo teve muitas oportunidades de ter o saber sobre o processo histórico da população negra através da troca de conhecimentos, experiências e também intervenções em razão da discriminação racial ocorrida dentro da escola. A atividade desenvolvida no mês de março foi sobre o Dia Internacional Contra a Discriminação Racial. Iniciei a aula dizendo-lhes que a partir daquele momento estavam proibidos de irem ao banheiro, tomar água e não queria saber da opinião dos alunos, pois quem manda na sala de aula é o professor. Os alunos ficaram surpresos com a imposição, questionaram a atitude e queriam uma explicação. Disse-lhes que a explicação estava embaixo de suas cadeiras; nelas, havia um texto que explicava: "O Dia Internacional de Luta pela Eliminação da Discriminação Racial foi criado pela Organização das Nações Unidas (ONU) e celebra-se em 21 de março em referência ao Massacre de Sharpevill”. Houve leitura e discussão do texto, bem como sobre o direito de ir e vir na sociedade, na comunidade em que residem, preconceitos e discriminações vivenciadas, direitos enquanto cidadãos e cidadãos negros (Políticas Públicas de reparação) e maneiras de convivência, 
respeitando a diversidade étnico-racial. Os alunos, em grupo, construíram cartazes com dizeres de respeito às diferenças étnico-raciais e os expuseram nos murais da escola.

Aluno(a): Marilia de Souza Negreiros

Escola: Escola Municipal de Educação Infantil Peixinho Dourado

\section{Título do trabalho: Sensibilização infantil: ludicidade e deficiência}

Resumo:

A proposta de intervenção foi programada para acontecer numa escola municipal de educação infantil com o tema ludicidade e deficiência. A Educação em Direitos Humanos vem ao encontro de capacitar o cidadão frente aos seus direitos desde a educação básica. O intuito do trabalho era que os alunos soubessem que somos todos diferentes e alguns precisam de outras formas de se locomover ou comunicar, mas todos devemos brincar juntos. Vivências, jogos, vídeos e contação de histórias são práticas educacionais que utilizamos para viabilizar a informação e são uma teoria do conhecimento posta em ação (Freire, 1996). O mobilizador da aprendizagem buscou integrar o deficiente e as crianças com a contação de histórias por uma adolescente cega a partir de livro escrito em braille, seguido das atividades com caixa, tapete e jogo da memória, todos táteis. Encerramos com a assistência a um vídeo e, posteriormente, uma discussão a respeito das diferenças, reforçando que todos são capazes, cada um com suas peculiaridades. O segundo turno iniciou com a contação de histórias. Em seguida, o mestre e telefone sem fio foram escolhidos para brincar com as crianças. Finalizamos com um vídeo apresentando a Língua Brasileira de Sinais como forma de comunicação. Com crianças, a forma de intervir deve se basear no lúdico. Rizzo (2001, p. 40) relata que “[...] A atividade lúdica pode ser, portanto, um eficiente recurso aliado do educador, interessado no desenvolvimento da inteligência de seus alunos, quando mobiliza sua 
ação intelectual [...]". Portanto, usando as mais diversas formas que estão disponíveis e que podemos criar em benefício da qualidade educacional, seremos formadores de opinião e de cidadãos sensíveis às necessidades de cada um. Se somos todos diferentes, temos que nos respeitarmos, e cada um auxiliar na dificuldade do outro. A proposta não foi colocada em prática devido às férias escolares.

\section{Aluno(a): Natália Vieira de Souza Silvã \\ Escola: Escola Fundamental La Salle Sapucaia e Escola Estadual de Ensino Fundamental Professora Silvânia Regina Ávila Alves}

\section{Título do trabalho: Direitos humanos para tod@s}

Resumo:

Os direitos humanos têm como finalidade a proteção e garantia da dignidade do ser humano, abrangendo todos os cidadãos. Sabemos que o nosso país já teve vários avanços, uma vez que tivemos cidadãos que lutaram por diferentes grupos na busca por equidade. O projeto Direitos humanos para tod@s surgiu a partir de conversas com os educandos de duas escolas da comunidade em que sou educadora. As atividades inicialmente partiram de observações e levantamento de hipóteses, imagens, vídeos, dinâmicas de grupos; com essas atividades intervimos no contexto escolar, levando os educandos a refletir sobre as violações dos direitos humanos. Juntos, educandos e educadores pensaram em ações coletivas para mudar a realidade da atual sociedade em relação ao tema direitos humanos. Partindo da realidade dos educandos, tivemos oportunidade de debater sobre as temáticas cor, raça e etnia, buscando a valorização das pessoas que fazem parte da nossa sociedade. Refletimos sobre os direitos humanos no contexto escolar, levando os educandos a pensar nas violações dos mesmos em diferentes contextos sociais, ou seja, na escola ou em qualquer lugar na nossa sociedade. Com o Projeto Direitos humanos para tod@s repensamos valores, objetivos e características que são importantes para o que vivemos 
e desejamos viver. Portanto, quando levamos para o contexto educacional assuntos diversificados como os direitos humanos, ampliamos o olhar do nosso educando, permitindo que o mesmo seja protagonista das ações da sociedade. Os educandos tiveram a oportunidade de dar opiniões e ideias, colocando-as em prática em suas atitudes do dia a dia.

Aluno(a): Priscila Estanislau

Polo Santo Antônio

\section{Título do trabalho: Conhecendo os direitos humanos}

Resumo:

O trabalho de conclusão de curso consistiu em um projeto de conscientização dos direitos fundamentais dos seres humanos. A proposta tem como foco a abordagem dos direitos humanos, respeito às diferenças e tudo que norteia o preconceito e a discriminação, com ligação a cidadania, deveres e direitos previstos na Constituição Federal e democracia, com ligação a resolução de conflitos e mediação. O objetivo é demonstrar aos alunos, através das atividades propostas, as desvantagens que o preconceito gera. O estímulo para que os alunos tenham a capacidade de identificar quando algum crime de discriminação está sendo praticado e, ao perceberem tal violação, saberem como agir. A partir desse conhecimento, qualquer projeto referente a respeito ao próximo, cidadania, mediação terá facilidade em sua aplicabilidade. 
Aluno(a): Rochele Jesus de Oliveira

Trabalho realizado em função da violação dos direitos de uma criança com necessidade especial, não em ambiente escolar.

\section{Título do trabalho: Todas as escolas são para todos os alunos}

Resumo:

O marcador social escolhido por mim é deficiência; então, venho falar de um ex-aluno da minha escola que tem paralisia cerebral e vem lutando por uma vaga no ensino regular. A escola, ou melhor, o estado, não disponibiliza uma monitora para atender esse aluno. Acho que isso é uma violação dos direitos dessa criança de querer estudar e não ser aceita por essa escola do estado. Onde está nossa dignidade de pessoa humana, nosso direito à vida? Como estão levando em consideração nossas necessidades especiais no planejamento econômico e social e onde está nossa igualdade de oportunidades? Somos uma população muito grande em todos os países do mundo para continuarmos ignorados e esquecidos por décadas e décadas, sendo vítimas silenciosas das violações dos direitos humanos. São vítimas de violações aqueles que estão privados de sua liberdade e também aqueles que não têm acesso à educação por não contarem com meios adequados de comunicação ou facilidades de acesso ao meio físico. As pessoas deficientes e/ou com necessidades especiais continuam entendendo que os seus direitos são desrespeitados e que estão assegurados apenas no papel. Então, pensei em fazer uma campanha virtual de mobilização através de cartazes para ajudar essa criança a ser um aluno incluso nesse meio, pois assim acho que seria uma campanha mais efetiva e simples de desenvolver, mas que iria tocar o coração e a consciência de cada cidadão. Para atingir os objetivos, ou seja, neutralizar ou eliminar o preconceito contra a pessoa com deficiência, devemos desenvolver ações fundamentais de conscientização, promovendo uma maior reflexão de comportamento nas pessoas em geral. 
Aluno(a): Taís Barbosa Rodrigues

Escola: Escola Municipal de Ensino Fundamental José de Anchieta

\section{Título do trabalho: Direitos humanos e cidadania no contexto escolar}

Resumo:

O presente estudo refere-se a uma proposta de intervenção desenvolvida em uma turma do $4^{\circ}$ ano na Escola Municipal de Ensino Fundamental de Santo Antônio da Patrulha, por ser uma turma que entra em conflito diariamente devido às diferenças entre os perfis de educandos, entre identidades. É importante reconhecer a necessidade de desenvolver atividades em que os alunos possam refletir sobre suas atitudes frente aos demais colegas e professores. Santos (2015, p. 1) destaca que "[e]m razão disso, os educadores têm se deparado com mudanças no perfil do alunado: é cada vez mais frequente a presença de estudantes que destoam dos demais em razão de algum marcador social de diferença". O objetivo foi proporcionar atividades e momentos de interação em que os educandos conheçam o Estatuto da Criança e Adolescente (ECA), bem como o Estatuto do Idoso. As seguintes atividades foram realizadas no momento da intervenção: pesquisa familiar; hora do conto; dinâmica; vídeo; construção de cartaz e de vídeo através dos desenhos. Os alunos não conheciam o ECA e o Estatuto do Idoso. No primeiro momento, os alunos selecionaram os colegas para ficar no grupo. Mas, com o decorrer da aula, mudaram de atitude e foram muito participativos, relacionando as rotinas familiares com a rotina escolar. Sendo assim, reconheço que no espaço escolar as crianças devem sempre ser incentivadas a respeitar o próximo. Santos (2015, p.4) diz que "[a] escola não transmite apenas conhecimento intelectual; também ensina a convivência coletiva". Os alunos conheceram o ECA e o Estatuto do Idoso, reconhecendo e valorizando seus direitos e deveres enquanto estudante, amigo, colega, filho, criança e adolescente. 
Aluno(a): Debora Velho Cunchertt

Escola: Escola Municipal de Ensino Fundamental Getúlio Dornelles Vargas

\section{Título do trabalho: Fazendo arte na escola com Romero Britto}

Resumo:

A atividade proposta foi a reprodução de painéis das obras do artista Romero Britto, pois sou professora de Artes em uma escola municipal onde o desrespeito entre os alunos era muito grande. Há turmas em que existem alunos portadores de deficiência, algo que me chamou a atenção, pois em todas elas existem um ou mais alunos com necessidades especiais, os quais sempre eram deixados de fora das atividades pelos colegas. Inicialmente, portanto, os trabalhos em grupos eram difíceis de ser realizados, pois os alunos especiais nunca eram escolhidos. Quando comecei com o projeto, havia muita resistência por parte dos alunos para a inclusão de seus colegas nos grupos, mas uma das condições era que todos deveriam participar, não poderia ficar ninguém sem grupo. O trabalho começou e diziam que não iriam conseguir, que era muito difícil, mas depois da segunda semana o resultado começou a aparecer, quando conseguiram visualizar o desenho completo; mesmo sem pintar, ficaram impressionados com o que haviam reproduzido. Após o trabalho terminado, ficaram encantados, os painéis ficaram lindos, então falei com a coordenação da escola e coloquei-os em exposição. Os alunos ficaram muito orgulhosos de seus trabalhos e conseguiram entender que não é por sermos diferentes que não somos capazes de realizar o que os outros fazem. Consegui atingir os meus objetivos com essa atividade, mesmo sabendo que ainda existe muito trabalho para ser realizado com as turmas. Pude perceber que durante a construção do painel os alunos conseguiram conversar, trocar ideias sobre como iria ficar melhor e, o que achei mais 
importante, conseguiram ouvir seus colegas sem brigas ou críticas. Tenho certeza de que aos pouquinhos vamos conseguindo mostrar para eles que respeito é algo que devemos ter por todos se quisermos que nos respeitem de volta.

Aluno(a): Delezia Teresinha Martins Da Luz

Escola: Escola Municipal de Ensino Fundamental Engenheiro joão Magalhães

\section{Título do trabalho: Possível intervenção em violação de direitos humanos}

Resumo:

A proposta planejada teve como objetivo principal apresentar as dificuldades e os preconceitos referentes às pessoas que vêm do interior do município de São Francisco de Paula. São ações que contrariam a educação e violam os direitos humanos dentro do contexto escolar. Os marcadores sociais escolhidos foram raça, cor e etnia. Neste trabalho, foram relatadas experiências vivenciadas em uma aula de estágio, na disciplina de Ensino Religioso, com uma turma de quinto ano do ensino fundamental na Escola Eng $^{\circ}$ João Magalhães, situada na sede, em São Francisco de Paula. Nela há vinte e quatro alunos com idades variando de dez a dezesseis anos, a maioria vinda do bairro local e outros vindos do interior deste município, com realidades bem diferentes entre si. Diante de toda a experiência compartilhada, ficou na sala e na escola a pergunta que atenta para o autoconhecimento e questiona a falta de sensibilidade, pois os colegas de classe que diferem na fala e vestimentas são produtores rurais, responsáveis, de certa forma, pelo abastecimento de hortifrúti em nossas mesas. Essa agressão verbal seria um sentimento de desconforto e inquietude diante de trabalhadores que se apresentam com a mesma faixa etária dos demais em sala de aula. Essa visão de descontentamento seria uma falta de preparação, já no âmbito familiar. Com muito diálogo, foi possível estabelecer o respeito, aceitando o colega 
com sua origem. Foi possível mostrar as diferenças culturais e partir para momentos de espaço para socialização de suas angústias e dúvidas. A partir do diálogo, foi construída uma base para o respeito a cada um, com suas especificidades.

Aluno(a): Jesica Hencke

Escola: Instituto Estadual de Educação Assis Brasil

\section{Título do trabalho: A complexa construção de gênero no âmbito escolar}

Resumo:

A atividade planejada envolveu um processo de autoanálise e compreensão etimológica dos termos gênero e identidade de gênero, perpassando por um processo de análise do espaço intraescolar com a pretensão de evidenciar como são percebidas as atitudes que refletem o preconceito e a discriminação sexual dentro do âmbito escolar. A análise foi feita a partir de um levantamento de impressões, descrições de cenas e conhecimentos prévios, relacionando-os com o Artigo $2^{\circ}$ da Declaração Universal dos Direitos Humanos. Pode-se destacar que falar de sexualidades no âmbito escolar é uma tarefa espinhosa, visto que envolve uma gama de preconceitos que ocasionam constrangimento para quem é vítima dessas ações. A atividade foi planejada para uma turma de $9^{\circ}$ ano do ensino fundamental numa escola estadual do município de Pelotas. Esse processo investigativo envolveu observação e escuta atenta. Debater gênero, sexualidade e diferenças numa esfera cultural contribui para o rompimento com a ótica da intolerância em busca de respeito, solidariedade e equidade de direitos e oportunidades; sabe-se que as potencialidades de um ser humano não se medem por sua orientação ou preferência sexual. Além do mais, a aprendizagem imersa em grupos heterogêneos contribui para uma compreensão ampla e multifocal das facetas que configuram o ser humano e sua vivência em sociedade e possibilita desmistificar pré- 
conceitos e concepções moralistas. Deflagrar as mazelas de uma educação que foca a sexualidade como fator biológico propenso ao adoecimento é o primeiro passo para pensá-la como construção social e cultural. Objetivouse perceber, no espaço da sala de aula, se há discriminação e obstrução dos direitos humanos em relação à identidade de gênero de cada estudante, além de observar o contexto escolar, registrar cenas que demarcam relações de gênero tornando-as conteúdo de análise e revalidação curricular. De forma metodológica, valeu-se da observação participante do contexto escolar; estudo de temas geradores, tais como gênero, identidade de gênero e sexualidade num processo interativo e dialógico.

Aluno(a): Luzia Santos

Escola: Escola Olímpio Soares Pinto

\section{Título do trabalho: Direitos humanos, gênero e preconceito racial}

Resumo:

Desenvolvi o meu trabalho sobre gênero. Apliquei a tarefa em uma turma de terceiro ano, na qual realizamos atividades sobre este tema e sobre preconceito racial, pois a turma apresentava muitos sintomas em relação a esse assunto. Usei o texto As borboletas, de Vinícius de Moraes; construímos borboletas com as mãos e usamos cores diferentes; após, juntamos as mãos, pintamos com têmperas e anexamos em um cartaz, para construirmos um texto sobre o respeito às diferenças. Assim, todos escreveram frases. Usei também a música do Patati e Patatá, Diferentes, e dramatizamos. 
Aluno(a): Marisa dos Reis Costa de Azevedo

Escola: Escola Estadual de Ensino Fundamental Monsenhor Armando Teixeira

\section{Título do trabalho: Marcador social das diferenças}

Resumo:

A partir do surgimento da violação de um dos direitos humanos (questão relacionada ao racismo), houve a intervenção do professor, conduzindo, através do diálogo, a uma percepção de que somos todos iguais e de que a construção do mundo e das belezas que há nele se dá devido às diferenças das etnias, isto é, diferentes culturas percebidas no mundo inteiro. Trabalhei leituras de diversos contos africanos, fazendo a interpretação, mostrando a eles o valor e a beleza da cultura negra, estabelecendo relações com o cotidiano. É com essas diferenças raciais que surgem as possibilidades de construções de conhecimentos diversos, na arte, na música, na religião, na literatura, na medicina, na dança, entre outras, e assim fui tecendo as minhas aulas, incluindo a leitura de contos africanos que ressaltam a beleza da cultura negra, mostrando os costumes, as crenças, os ritmos musicais inclusos na cultura brasileira. Concluímos o trabalho através de uma reflexão de que devemos olhar o outro, percebendo, notando e observando não as diferenças de cor de pele, mas sim os saberes diferentes que cada um pode trocar e agregar aos nossos conhecimentos. Com isso, percebemos que esses "diferentes saberes" existem em cada um, no preto, no branco e no índio, que, somando, trocando e agregando, constroem novos saberes e conhecimentos e que o importante é saber que, independentemente das diferenças, é preciso manter cordialidade e respeito em relação a tudo o que é diferente. 
Aluno(a): Natacha Scheffer

Escola: Escola Municipal de Ensino Fundamental João Antonio Satte

\section{Título do trabalho: Diversidade na sala de aula: vivências cotidianas}

Resumo:

O trabalho foi realizado com o intuito de refletir, conscientizar e valorizar o respeito às diferenças. Teve como objetivo levar os educandos a conhecer e respeitar as diferentes origens étnicas, percebendo o valor da sua própria história e o resgate da autoestima. Foram realizadas atividades de contação de histórias, discussão sobre a temática escolhida e produção de material. Observou-se nas discussões dos pequenos grupos que os alunos não utilizaram termos pejorativos ou realizaram brincadeiras que tivessem teor agressivo no que se refere às questões étnico-raciais. A construção identitária dos sujeitos é um processo que decorre de uma produção cultural, na qual a vivência das diferenças é constitutiva, e a marcação social da diferença é repleta de ações de inclusão e exclusão, de demarcação sobre quem pertence a determinado grupo e quem não pertence. Pensando nesse processo, vivenciar e confrontar diferenças no microcosmo da sala de aula é a possibilidade de se enxergar e enxergar aos outros em um ambiente no qual a mediação dos conflitos emergentes confere aos sujeitos alternativas de resolução dentro de um ambiente educativo e protetor. Não é possível, ainda, verificar se o projeto de intervenção de fato eliminará ou diminuirá as situações observadas inicialmente; mas a reflexão consistente que se estabeleceu a partir deste trabalho com certeza interferirá positivamente nas relações estabelecidas no ambiente escolar. 
Aluno(a): Quellen Rodrigues da Silva

\section{Título do trabalho: Intolerância Religiosa - A importância de trabalhar ensino religioso nas escolas}

Resumo:

Este foi o marcador que escolhi para a finalização do curso de Educação em Direitos Humanos EAD, por ser um assunto intrigante e por gerar diversos casos de preconceito e intolerância, violando assim os direitos humanos.

No decorrer do curso, analisando alguns casos, impressionei-me com um caso em especifico, ocorrido em uma cidade em que trabalhei, onde o professor teve seu contrato cancelado ao falar sobre "Umbanda" quando trabalhava religiões em sua turma. Existe um preconceito explícito de pais, alunos e até mesmo colegas professores sobre tal assunto. Sendo assim, com a proposta final de elaborar uma intervenção, dentro do contexto escolar, resolvi fazer uma pesquisa na escola em que eu trabalho, para concluir se os mesmos demonstram interesse e importância em ensino religioso nas escolas.

Esta pesquisa foi realizada em uma escola municipal de educação infantil.

A pesquisa foi feita com 10 questões, onde se revelou que três entrevistados eram evangélicos, um agnóstico, e um católico não praticante e atualmente espírita. Todos concordaram que existe importância em conhecer as religiões, mas que não se sentem a vontade de trabalhar religiosidade.

Enfim, ficou claro que apenas com essa simples entrevista, encontramos diferentes seguimentos religiosos em um ambiente escolar, e que os professores se sentem perdidos e acabam trabalhando ensino religioso, apenas direcionando a valores sociais. 
Aluno(a): Regina Mariza Martins Bosquetti

Escola: Colégio Estadual José de Alencar - CEJA

\section{Título do trabalho: Marcador social de diferença: pertencimento regional.}

Resumo:

Trabalhei em sala de aula com a abordagem do texto Pechada, de Luís Fernando Veríssimo, a partir do qual os alunos, através da leitura e interpretação, mais incentivo e dinâmica, refletiram sobre suas atitudes e falta de entendimento das relações sociais na escola. Entre tantas situações identificadas em sala de aula, uma que parecia brincadeira mas que por ser repetitiva fugiu a essa regra é que os alunos riam e imitavam as falas dos novos colegas, a pronúncia forte da vogal "e" no final das palavras, expressões como "te aquieta"; o que estava deixando os alunos sem jeito e desconfortáveis. Antes da leitura do texto, questionei os alunos: falamos a mesma língua no Brasil inteiro? Vocês conhecem ou já falaram com pessoas que falam diferente? Como vocês percebem que uma pessoa é de outra região ou estado? Como vocês agiriam se alguém não entendesse o que você fala? No início, alguns alunos não estavam muito à vontade e perguntaram para que se apresentar se todos já se conheciam; expliquei que tinham novos colegas e seria diferente cada um apresentar o colega, poderiam conversar mais de perto e descobrir novas informações que não sabiam. Após a conversa, foram realizadas as atividades de apresentação e motivação envolvendo o grande grupo; eles foram percebendo, através da socialização das ideias, que todos tinham o mesmo direito de falar o que pensavam, porém tinham limites que não poderiam ultrapassar, porque estavam faltando com o respeito com o colega. O restante da aula foi tranquilo, todos participaram demonstrando interesse. 
Aluno(a): Rudinei Silva dos Santos

Escola: Colégio Guianuba

\section{Título do trabalho: Sentindo na pele a inclusão escolar}

Resumo:

A atividade foi desenvolvida com alunos do primeiro ano do ensino médio, em que eles trabalharam e refletiram sobre os direitos das pessoas portadoras de necessidades físicas. A aula foi de caráter dialógico e expositivo, tendo como principais recursos a sala de aula, os corredores e demais dependências da escola. A turma foi dividida em trios e foi solicitado que cada um desses trios representasse um tipo de necessidade física pré-estabelecida; enquanto um faria o papel do portador, outro o ajudaria e o último faria anotações. Depois de certo tempo de deslocamento pelas dependências escola, eles foram reunidos para discutir as anotações. Cada grupo mostrou as dificuldades enfrentadas, os preconceitos e constrangimentos sofridos por essas pessoas. Constatou-se então que a escola não estava totalmente preparada para a acessibilidade e acolhimento dessas pessoas. Em consenso com a turma, redigimos um relatório, descrevendo o que encontramos e o que poderia ser feito para garantir o direito de acessibilidade às pessoas portadoras de necessidades físicas. A avaliação final desse plano de aula se deu avaliando a participação de todos durante o processo de realização das atividades, bem como o interesse de cada indivíduo no processo de compreensão dos direitos humanos vivenciados durante a atividade. A coordenação da escola foi convidada a participar da exposição do relatório e escutar os depoimentos dos alunos que fizeram o papel da pessoa deficiente. Essa aula foi muito produtiva, pois constatamos que algumas pequenas melhorias já fariam uma grande diferença na qualidade de vida dessas pessoas e que muito ainda tinha que ser feito. Essa atividade foi de cunho pedagógico e inclusivo e não foi objeto de imitação de algum caso real que por ventura existia em nossa escola ou com o intuito de expor qualquer pessoa a algum constrangimento. 
Aluno(a): Silvana Castilhos Steyer

Escola: Escola Estadual de Ensino Fundamental Monsenhor Armando Teixeira

\section{Título do trabalho: Combatendo o machismo na escola}

Resumo:

O marcador de diferença escolhido para o desenvolvimento do projeto foi "gênero", por considerar que a escola inicie esse processo de sensibilização em relação às questões sexistas através de trabalhos e projetos que combatam a prática do machismo. Trabalhos como esse podem e devem ser desenvolvidos desde a educação infantil, período em que as crianças estão construindo conceitos e hipóteses no que se refere ao conhecimento e às relações sociais e culturais, ou seja, num processo cognitivo e afetivo. A escola escolhida foi uma escola pública de São Francisco de Paula; ela possui uma clientela de alunos distribuídos na educação infantil, anos iniciais e finais do ensino fundamental. $\mathrm{Na}$ educação infantil, 20 alunos vão à escola no turno da tarde. As atividades extraclasse, como Informática, Educação Física e Biblioteca são desenvolvidas em espaços próprios para tal. O projeto foi desenvolvido a partir de uma história infantil, com o objetivo de estimular as crianças à sensibilidade em relação à temática do gênero. A história, reproduzida no datashow, foi Príncipe Cinderelo, de Babette Cole. Ela foi apresentada às crianças fazendo todas as pausas necessárias para que as mesmas refletissem em relação aos acontecimentos. Em seguida, relembramos a história da Cinderela, para que fizessem algumas relações com a do Príncipe Cinderelo. Algumas questões foram propostas para o debate: será que os homens podem fazer as tarefas de casa, como lavar a louça, arrumar as camas e estender as roupas? As mulheres (princesas) podem escolher seus maridos e companheiros? As crianças expuseram suas ideias, suas vivências de casa e de como percebem essas relações na família. Durante o desenvolvimento da atividade, as crianças ficaram muito à vontade para responder os questionamentos. Foi possível perceber algumas formas de preconceito na fala das crianças em relação à questão de gênero. Todas foram 
enfáticas em afirmar que os pais ajudam as mães nas tarefas de casa, como se essas atividades fossem "naturalmente" designadas às mulheres.

Aluno(a): Vera Lúcia Carneiro Fucks

Escola: Escola Família Agrícola da Serra Gaúcha - EFASERRA

\section{Título do trabalho: Educação do campo: refletindo sobre identidade e conflitos geracionais}

Resumo:

Pretende-se, neste trabalho, propor aos alunos do $1^{\circ}$ ano do ensino médio do curso Técnico em Agropecuária a reflexão sobre os temas identidade e diversidade geracional, analisando, interpretando e reconhecendo as singularidades, os desafios e as conquistas da população que vive no campo. As atividades planejadas para trabalhar os temas seguem a pedagogia da alternância, método de estudo adotado pela escola; ou seja, os alunos ficam uma semana em casa e uma semana na escola. O planejamento foi realizado junto com professor Arnaldo Poletto e foi dividido em cinco momentos. Primeiro, uma técnica de apresentação, refletindo o conceito de identidade e diversidade geracional (o aluno é provocado a refletir quem é; quem poderá ser; do que gosta; de quem gosta). Segundo, o momento de escuta de cada um dos alunos, a partir das informações e percepções trazidas. Terceiro, a abordagem dos conceitos trabalhados - identidade, diferença, jovem-adulto (urbano-rural), idoso (urbano-rural) - contextualizados com a legislação (Estatutos da Criança e do Adolescente e do Idoso) e com a apresentação dos alunos. Quarto, pesquisa e registro junto às suas comunidades rurais. Por último, houve o compartilhamento e a análise dos dados pesquisados, tendo como questionamento orientador as perguntas: pensando na vida do campo, no contexto em que vivem vocês, viviam os seus pais, os seus avós, quais as principais mudanças que vocês percebem do homem/mulher/ jovem do campo com relação a identidade com a terra? O que provocou/ provoca essas mudanças? A escolha do trabalho se justifica pelos sentimentos 
demonstrados pelo aluno/jovem agricultor, desencadeados pelo "conflito geracional". O objetivo principal do trabalho é provocar no aluno(a) a reflexão do eu, da família e da terra, reconhecendo-se nesse meio. Este trabalho está em desenvolvimento; os resultados parciais demonstram que o corpo docente da escola valoriza e apoia as atividades que envolvem a reflexão de atitudes, conceitos e valores dentro da temática de direitos humanos.

4. POLO: SAPUCAIA

Aluno(a): Amarildo Augusto Veiga

Escola: Escola Municipal de Ensino Fundamental José Loureiro da Silva

\section{Título do trabalho: Eu não quero que me tolerem, eu quero que me respeitem!}

Resumo:

O presente trabalho foi realizado como pré-requisito para a conclusão do Curso de Extensão da UFRGS de Educação em Direitos Humanos - Edição de 2015/01. Pretendeu-se abordar as relações étnico-raciais no ambiente escolar a partir da necessidade de ampliar o combate ao racismo. O trabalho foi realizado por meio de atividades práticas em sala de aula na Escola Municipal de Ensino Fundamental José Loureiro da Silva, em Porto Alegre, ao longo do mês de julho de 2015. Foram utilizados recursos de filmes e documentários em DVD; sala de informática para pesquisa na internet e aula expositiva dialogada com elaboração de cartazes. Na primeira semana, realizamos a exibição do documentário A Cor da Cultura Mojubá. A partir dos programas, iniciamos um debate sobre as expressões da cultura africana. Questionou-se a perseguição 
que sofrem as religiões de origem africana e o fundamentalismo religioso das religiões neopentecostais, que afirmam que as religiões de origem africana não são religiões e sim seitas. Na terceira semana foram realizados trabalhos com desenhos e recortes de revistas para a elaboração de cartazes sobre a questão racial. Pretende-se dar continuidade com a visita dos Educadores do Quilombo do Sopapo. Percebe-se a partir deste trabalho que há um longo e árduo caminho para avançarmos no combate às discriminações e ao racismo. A escola é um ambiente privilegiado, pois todas as crianças passam por ela e serão elas os adultos e adultas do futuro próximo. Por isso, cabe às professoras e aos professores a militância cotidiana, com vistas a um futuro mais digno e menos excludente; enfim, um mundo no qual os direitos e garantias fundamentais e individuais dos seres humanos sejam respeitados.

Aluno(a): Brasinicia Tereza Tápia

Escola: Escola de Ensino Fundamental América

\section{Título do trabalho: Educação em Direitos Humanos}

\section{Resumo:}

A cultura da violência presente em diversas comunidades escolares requer uma ação continuada de esforços para que seja, aos poucos, abolida. A identificação e a intervenção ao bullying são medidas necessárias para que seus efeitos sejam evitados e/ou minimizados. As crianças ou adolescentes que sofrem bullying podem se tornar adultos com sentimentos negativos e baixa autoestima. Elas tendem a adquirir sérios problemas de relacionamento, podendo, inclusive, contrair comportamento agressivo. Os atos de bullying ferem princípios constitucionais de respeito à dignidade da pessoa humana e o Código Civil. Diante da importância do tema, propôs-se um diálogo sobre a temática explorada com a turma B12, $2^{\circ}$ ciclo do ensino fundamental da Escola de Ensino Fundamental América, em Porto Alegre. Partindo da afirmação de diversos autores de que a violência doméstica se reflete na escola muitas vezes na forma de bullying e com o objetivo de minimizar comportamentos 
inadequados, tais como apelidos e discriminação através do diálogo, procuramos conscientizar os alunos da responsabilidade e do envolvimento de cada um no processo de aprimorar os relacionamentos intra e interpessoais do grupo. Durante as atividades propostas, os alunos demonstraram interesse e relataram inúmeras situações em que haviam sofrido e até mesmo provocado bullying. É interessante oportunizar as crianças a falar de si mesmas, ajudálas a tomar consciência de sua existência e construir suas representações. Tognetta (2004) esclarece que as crianças quando falam têm a possibilidade de ressignificar os sentimentos e emoções presentes em si e, comunicando aos outros, ou mesmo à professora ou aos pais, têm possibilidades de autocontrole e autoconhecimento. Assim, é necessário que o professor incentive o diálogo em suas aulas. Essas manifestações dão às aulas um clima de respeito mútuo, fazendo com que os alunos entendam a importância de respeitar o colega e de dialogar ao invés de ofender e brigar; isso é fundamental.

Aluno(a): Cristina Lima Hofer

Escola: Colégio La Salle

\section{Título do trabalho: Marcador de diferença raça/etnia}

\section{Resumo:}

No que se refere ao processo de marcação social da diferença, é preciso salientar que há sempre ações de inclusão e exclusão, ou seja, de demarcação sobre quem pertence a determinado grupo e quem não pertence. Essa classificação ou distinção também indica hierarquias, como relações de poder e atribuição de valores aos diferentes grupos classificados (Carlos, 2015). O marcador de diferença raça/etnia identifica um povo pela cor da pele, seu cabelo, cor dos olhos, música e cultura, podendo assim identificar e excluir indivíduos da sociedade. Essa exclusão pode ser identificada na sociedade na forma de injúrias, na forma de impedir acessos a clubes recreativos, na desigualdade salarial e na falta de acesso e permanência em escolas, gerando assim impacto social e econômico. No Brasil, as lutas pelo reconhecimento 
e pela cidadania da raça negra tiveram início já no tempo da escravidão, que durou desde o "descobrimento" do país por Portugal, no ano de 1500, até o século passado, com a chamada "abolição" (Tramonte). Ao analisarmos três séculos da história, desde a chegada dos negros como escravos no Brasil até os dias atuais, podemos considerar sim que o preconceito com a raça negra é uma construção cultural e histórica da sociedade brasileira, através de atos de marginalização e exclusão. De um modo geral, os negros foram privados ou tiveram dificuldade de acesso ao emprego, à moradia, à educação, à saúde, à participação política; enfim, ao exercício pleno da cidadania. Esses processos de desigualdades e violações dos direitos humanos da raça negra geraram impactos na construção e manutenção da identidade destes e cabe ao cidadão nos dias atuais refletir sobre esses processos de constituição e formação de identidades e diferenças geradas pelos marcadores sociais ainda existentes. A criação de leis específicas com o intuito de diminuir a exclusão e a marginalização da raça negra na sociedade brasileira vem confirmar as desigualdades e as violações dos direitos humanos desses indivíduos. A educação tem sido fomentada como ferramenta para diminuição das desigualdades sociais, tanto como disseminadora de conhecimento a sociedade em geral, como potencializadora e emponderadora desse grupo de indivíduos.

Aluno(a): Dalvana Silva da Gama

Escola: Trabalho de pesquisa teórica, para subsidiar ações em escola.

\section{Título do trabalho: Escolas e alunos gaúchos dão lição de direitos humanos}

Resumo:

Com a crescente migração de haitianos para o Brasil, temos também o aumento das denúncias de preconceito contra esses imigrantes. Devido a essas atitudes discriminatórias, surgiu a preocupação quanto aos direitos dos pequenos haitianos que vêm ao Brasil acompanhando seus pais. Assim, 
este trabalho busca verificar, com base no Artigo 26 da Declaração Universal dos Direitos Humanos, se o direito à educação está sendo assegurado aos filhos desses imigrantes nas escolas da região metropolitana de Porto Alegre. Inicialmente foi bastante difícil encontrar escolas com alunos haitianos, já que a maioria dos imigrantes são homens e deixam suas famílias no Haiti. Foram encontradas duas escolas na região metropolitana de Porto Alegre: uma possuía duas alunas no ano de 2014, hoje residentes em Brasília, uma matriculada no $1^{\circ}$ ano e outra no $2^{\circ}$ ano, por já ter sido alfabetizada em francês; a outra escola tem quatro alunas haitianas, duas com 10 anos de idade e matriculadas no $4^{\circ}$ ano, uma de 7 e outra de 9 anos, ambas no $3^{\circ}$ ano. Essas escolas relatam projetos de integração sociocultural e programas de auxilio aos estudantes para o desenvolvimento das linguagens oral e escrita em Língua Portuguesa e destacam que os demais alunos não demonstram qualquer atitude de preconceito, mas sim grande atração por essas colegas que falam outra língua e vêm de um lugar tão distante e desconhecido pela maioria, tornando as alunas haitianas muito populares nas escolas onde estudam. Assim, apesar da dificuldade em encontrar escolas com alunos haitianos, as poucas escolas encontradas dão uma verdadeira lição de direitos humanos, tanto por parte da administração escolar como pelos alunos brasileiros, que recebem sem restrições esses imigrantes que vêm ao nosso país em busca de uma melhor qualidade de vida.

Aluno(a): Debora Costa De Borba Silva

Escola: Escola de Ensino Médio Santa Isabel - Viamão

\section{Título do trabalho: Diversidade e relações étnico-raciais}

\section{Resumo:}

Temos uma necessidade básica no convívio social: partilhar, ou melhor, compartilhar experiências. Assim, mostra-se a diversidade de todos os modos e lugares: cultual, étnico-racial, e com isso o homem deverá ser capaz de se relacionar com todos. Os temas discutidos com os alunos foram 
sobre raça, racismo, etnicidade, cultura afro-brasileira, políticas de ações afirmativas e diversidade cultural. Foi feita uma roda para a discussão e, com base nas falas, foi verificado se alguém, em algum momento da sua vida, sofreu violação dos direitos humanos. Relato dos discentes: sim, já sofreram alguma violação. Debatemos os artigos dos Direitos Humanos e da Constituição Federal. Conforme o Art. 5 , somos todos iguais perante a lei. Sim, somos, pois é uma garantia de direitos individuais e coletivos porque vivemos em uma democracia igualitária. A Declaração Universal dos Direitos Humanos, Artigo $2^{\circ}$, diz que "todo o homem tem capacidade para gozar os direitos e as liberdades estabelecidos nesta Declaração sem distinção de qualquer espécie, seja de raça, cor, sexo, língua, religião, opinião política ou de outra natureza, origem nacional ou social, riqueza, nascimento, ou qualquer outra condição". Em suma, é necessário que conheçamos a diversidade da sala para que possamos compartilhar informações e, assim, as diferenças devem ser respeitadas por todos. É uma tarefa para todos, crianças, jovens e adultos, a partir de princípios coerentes com a dignidade humana e com a intenção explícita de promover a cidadania pautada na democracia, na justiça, na igualdade, na equidade e na participação ativa de todos os membros da sociedade nas decisões sobre seus rumos.

Aluno(a): Fernanda Maciel da Silveira

Escola: Escola Estadual de Ensino Fundamental de Sapucaia do Sul

\section{Título do trabalho: A rua e a vulnerabilidade social}

Resumo:

O plano de aula foi executado com a finalidade de chamar a atenção dos alunos para a questão da vulnerabilidade social. A atividade foi planejada para cinco períodos de Ensino Religioso e Língua Portuguesa em que os alunos teriam de ler a crônica De quem são os meninos de rua?, de Marina Colasanti, para produzir uma narrativa e realizar um debate do qual sairia uma proposta de intervenção social. A produção textual 
consistia em uma narrativa em que o aluno deveria contar a história de um jovem que vai morar na rua devido a um problema muito sério em sua casa. Analisando os textos, verifiquei que muitos escreveram sobre crianças e adolescentes que fugiram de sua residência porque apanhavam dos pais, sofriam abuso sexual, usavam drogas, não tinham apoio familiar, etc. No outro dia, a crônica foi debatida tendo em vista a Declaração Universal dos Direitos do Homem, as experiências que os alunos tiveram na escrita do texto e o que eles pensam sobre o assunto. Surgiram muitas ideias e questionamentos que levaram à sensibilização do grupo quanto às desigualdades sociais e a nossa responsabilidade, como membros da sociedade, pelas injustiças. No meio da conversa, um dos alunos teve a ideia de ajudar as pessoas que ficaram desabrigadas devido à enchente que assolou a região metropolitana e a proposta foi aceita pela maioria. Combinamos que, no dia seguinte, eles trariam mantimentos, os quais eu levaria ao ginásio onde estes estavam sendo organizados e distribuídos, o que, de fato, foi feito. Além disso, alguns foram voluntários, colaborando a tarde inteira na organização dos itens doados. No entanto, mais importante do que a decisão deles em ajudar as pessoas atingidas por esse desastre foi a sua sensibilização, a empatia e a real preocupação com o outro.

Aluno(a): Giovana Augusta Gross Campos

Escola: Unidade do CRAS Centro de Referência em Assistência Social

\section{Título do trabalho: Violência, medo e amor}

Resumo:

Visando contribuir com as reflexões obtidas sobre gênero na educação de Direitos Humanos ao longo do curso, busquei um local onde encontrasse um público-alvo que necessitasse discutir e debater esse assunto, com a intenção de ajudar de alguma forma mulheres carentes de informações, conhecimentos e, principalmente, amor próprio. O objetivo foi levar até as mulheres menos esclarecidas informações sobre a legislação 
de proteção a mulher, a Lei Maria da Penha, a fim de orientar que elas possam mudar a realidade em que se encontram. Reunidas em um Centro de Referência de Assistência Social na cidade de Sapucaia do Sul, fizemos um círculo e, em uma breve apresentação, cada uma expôs o que quis sobre sua vida. Após, expliquei a importância dos direitos humanos de forma simplificada e explanei sobre a Lei Maria da Penha. Logo em seguida, iniciaram-se os relatos e houve uma troca de experiências entre as participantes. $\mathrm{O}$ encontro com as participantes e a dinâmica usada enriqueceram a proposta da atividade aplicada. A participação de cada uma encorajou a próxima a realizar seu relato e questionar as dúvidas pertinentes, sem medo e sem receio. Após o trabalho, pôde-se perceber a reflexão nos posicionamentos e relatos de cada uma delas. Percebi que a maioria já conhecia a Lei Maria da Penha, mas acabava aceitando sua situação por medo de perder seus parceiros ou mesmo por pensarem que é tudo normal, que foi assim com a avó, é assim com a mãe e deve ser assim com elas também.

Aluno(a): Nilda Franchi

Escola: Escola Estadual de Ensino Médio Cristo Rei

\section{Título do trabalho: Direitos humanos: a mulher e o mercado de trabalho}

Resumo:

A Declaração Universal dos Direitos Humanos afirma que "todas as pessoas nascem livre e iguais em dignidade e em direitos", independente de sexo, raça, crença, cor, posição econômica, opção sexual, religiosa ou política de seu povo. Entretanto, a consciência de tais valores se perdeu e suas violações se infiltraram no campo dos direitos civis, políticos, econômicos e sociais, agravando a violência e a intolerância nesses âmbitos. Na esfera do Direito do Trabalho, as mulheres continuam sofrendo muitas formas de exclusão e violência que refletem o imaginário social. Tal dominação 
estabelece e internaliza como legítimo e natural o lugar estabelecido para a mulher, para mãe e para a trabalhadora, velando a questão de gênero. Assim, sua inserção nos espaços públicos rompeu com esse sentido tradicional. Destarte, esse estudo desvelou que essa figura, tornada invisível pelo mercado de trabalho e esferas produtivas, convive com problemas como a inferioridade salarial, o não reconhecimento laboral ou intelectual, a dupla jornada de trabalho, os assédios e, na maioria das vezes, as piores áreas de trabalho. A partir de um questionário aplicado, foi possível comprovar ou refutar algumas hipóteses da pesquisa: 47\% dos respondentes têm conhecimento de que alguma mulher de seu meio social sofreu assédio moral/sexual no ambiente de trabalho; $16 \%$ deles têm notícia de que alguma mulher foi impedida ou teve sua licença maternidade afetada de alguma forma; 34\% das mulheres/mães são as únicas responsáveis pelos afazeres da casa. Sobre a disparidade salarial entre os gêneros, 53\% dos entrevistados concordam que esse fenômeno exista; os outros 37\% têm o fato como um mito. Asseveramos que, enquanto não forem mudadas as relações dentro da família, ou da sociedade, não mudarão outras relações, posto que a ideia de sua criação seja denominada pelo poder masculino.

Aluno(a): Patrícia Glaeser de Souza

Escola: Escola Municipal de Ensino Fundamental São João Batista

\section{Título do trabalho: Inclusão e diversidade}

Resumo:

A construção de uma sociedade inclusiva pressupõe o respeito e a valorização da diversidade, o direito de igualdade de oportunidades e a garantia da dignidade e dos direitos humanos. Entende-se por inclusão o acesso de todos ao espaço comum da vida em sociedade; sociedade esta que deve estar orientada por relações de acolhimento à diversidade humana, de aceitação das diferenças individuais e de esforço coletivo na equiparação de oportunidades de desenvolvimento. O objetivo geral deste trabalho é 
conscientizar os alunos a respeito da inclusão e diversidade. Entre os objetivos específicos, estão: oportunizar ao aluno o desenvolvimento da autonomia e da responsabilidade; possibilitar reflexões éticas e valores morais; reconhecer direitos e deveres; refletir sobre suas ações na convivência social; resgatar a autoestima; perceber-se como membro importante na sociedade; respeitar e compreender as diferenças em suas várias dimensões e formar cidadãos críticos e reflexivos. Em uma turma de $2^{\circ}$ ano, ficamos em roda e fiz a leitura do livro $O$ Emaranhado da Maçaroca, que aborda a infância e a percepção de mundo de um deficiente visual por meio da história de dois meninos que se conhecem por acaso e se tornam amigos; além da amizade, nasce também uma relação de troca e respeito. Os alunos prestaram atenção e gostaram muito da história. Quando terminei de ler, já vários alunos haviam pedido a vez para falar. Eles relataram o que entenderam e após dialogamos sobre outras deficiências, como a surdez, deficiência mental, deficiência física, síndrome de down e autismo. Os alunos contaram situações que vivenciam em suas famílias e entre amigos; todos assistiam aos relatos com muito interesse. Eles perceberam com essa troca de experiências que todos nós somos diferentes e precisamos respeitar todos os seres humanos. Eles realizaram desenhos sobre o que tínhamos trabalhado na sala de aula.

Aluno(a): Raphael Vieira Medeiros

\section{Título do trabalho: A justiça ao alcance de todos}

Resumo:

O Juizado Especial Cível foi idealizado como forma de inclusão ao judiciário para as pessoas de baixa renda, tornando assim acessível o ingresso para a população carente, que até então era excluída desse processo. Dessa forma, a criação do juizado foi norteada a partir de critérios para tornar mais simples esse acesso ao judiciário. Por esta razão, foram estabelecidos os princípios norteadores do Juizado Especial Cível, que são: oralidade, simplicidade, informalidade, economia processual e celeridade. Outro fator importante se refere ao seu ingresso, que é gratuito, com o intuito de, sempre 
que possível, buscar a conciliação entre as partes. Muito embora haja esta gratuidade, a mesma preponderará até a sentença de primeiro grau. Após, o indivíduo deverá comprovar ausência de provimentos para interposição de recurso. O valor da causa da ação não pode ultrapassar 40 saláriosmínimos. Nas causas de até 20 salários-mínimos, não há a necessidade de contratação de advogado. As ações que tramitam no Juizado são aquelas que geram danos de ordem patrimonial e/ou moral, seja por cobrança devida ou indevida de dívida, por acidente de trânsito, por compra de um produto com defeito, entre outras. Entretanto, não podem ingressar no Juizado Especial Cível as causas de natureza alimentar, falimentar, fiscal e de interesse da Fazenda Pública, e também as relativas a acidentes de trabalho e ao estado e capacidade das pessoas. Diante de tais características, o Juizado Especial Cível destina-se, portanto, a tornar a justiça acessível a todos, sendo que a melhor forma de inclusão é primeiramente ouvir, para assim identificar qualquer desequilíbrio e somente a partir disso buscar uma solução para restaurar um equilíbrio social.

Aluno(a): Roberta Borges Morch

Escola: Escola Municipal de Ensino Fundamental Aurialicia Chaxim Bez

\section{Título do trabalho: Projeto Bolsa Amarela: menino pode? E menina não pode?}

Resumo:

O livro A bolsa amarela conta uma história atraente e sugestiva, mas também mostra a realidade de muitas famílias com problemas financeiros e muitos filhos. A leitura possibilita a criança a criar fantasias e assim permite melhorar o convívio social e afetivo na família, dada a diversidade de personagens e suas situações cotidianas. O livro abre espaços para a criança expressar seus sentimentos, frustrações, alegrias, esperanças, etc., e mostra situações do cotidiano nas quais discussões sobre a diversidade de gênero aparecem muitas vezes de forma machista. Foram analisadas e discutidas 
falas do livro. Esse projeto ajudou a trabalhar com a turma a questão de gênero: o que é coisa de menino ou de menina? Será que menina pode fazer de tudo ou só o menino? Esse trabalho foi importante, pois havia meninas que gostavam de jogar bola e os meninos não deixavam. Hoje, todos jogam futebol em times mistos. Algumas falas das crianças eram bem significativas (podendo virar mais tarde preconceito), porém hoje elas já se conscientizam de que a mulher pode "ser o chefe da casa".

Aluno(a): Silvana Silva da Silveira

Escola: Escola Municipal de Ensino Fundamental Vanessa Ceconet

\section{Título do trabalho: Os pequenos dando o exemplo}

Resumo:

Mesmo nos dias atuais, com o acentuado trabalho realizado em prol do término do preconceito e com leis sendo sancionadas para proteger os grupos que sofrem com a desigualdade social, é comum, ainda, atitudes preconceituosas sendo observadas como normais. A escola é o cenário social onde vivenciamos as mais diferentes situações de práticas de marcadores sociais da diferença, sendo o racismo muito comum. Na escola onde trabalho, presenciei um aluno do primeiro ano do ensino fundamental negarse a sentar ao lado de um colega da mesma turma, negro. Relatei o fato à professora titular da turma, que me disse já ter percebido algumas atitudes semelhantes em sala de aula. Para minha intervenção, planejei atividades visando motivar os pequenos através do lúdico e incentivar o respeito pelas diferenças. Iniciei com a apresentação do vídeo $O$ cabelo de Zedi. Este pequeno filme mostra a insatisfação de um menino negro com seu cabelo. A segunda parte do trabalho foi realizada com a apresentação de slides contando a história $O$ segredo da caixa vermelha. Dentro da caixa havia um espelho e foi possível desenvolver a identidade social/pessoal e o conceito de que todos são diferentes. A terceira atividade foi com o livro Menina bonita do laço de fita. Acharam muita graça a cada história que a menina usava para justificar 
a sua cor pretinha. Os alunos demonstraram interesse em falar sobre o assunto; todos queriam relatar o seu entendimento. Uma intervenção bemsucedida de um conflito no âmbito escolar depende de um trabalho diário e constante. Cabe à escola, formadora de opiniões, oportunizar momentos de reflexão, compreensão e diálogo para que os alunos possam expressar o que pensam, respeitando a opinião do outro.

Aluno(a): Vivian Castilhos Pires

Escola: Colégio Municipal de Ensino Básico Dulce Moraes

\section{Título do trabalho: Deficiências}

\section{Resumo:}

Esse tema que escolhi foi para conscientizar os alunos de que existem pessoas com deficiência também na escola e que todos possuem os mesmo direito e deveres perante a sociedade, a fim de possibilitar a integração e socialização de todas as crianças sem distinção de etnia, deficiências, gêneros, etc., em um mesmo âmbito escolar. Com os alunos, trabalhei os vídeos Cuerdas e Meu tênis, abordei a existência de vários tipos de deficiência e fizemos debates explicando que devemos respeitar as diferenças. Os alunos obtiveram ótimos resultados durante a aula; cada um fez seu relato sobre os vídeos que assistiu, suas ideias e dúvidas e também muitas críticas com relação ao preconceito. Cuerdas conta a história de Maria, uma menina que vive em um orfanato e que criou uma ligação muito especial com um colega de classe que tem paralisia cerebral. Igualdade, solidariedade, amizade e amor, sentimentos que muitas vezes não são encarados com a seriedade com que deveriam. Meu tênis mostra como nós nunca estamos satisfeitos com o que temos e às vezes julgamos o próximo precipitadamente, sem saber os problemas que as outras pessoas também enfrentam, apesar das aparências. Nós, educadores, precisamos nos engajar na questão social e política, percebendo as possibilidades da ação social e cultural na luta pela transformação das estruturas opressivas das sociedades classista. 


\section{Alessandra Maria Bohm}

Mestre em Educação pelo Programa de Pós-Graduação em Educação da UFRGS, Bacharel em Psicopedagogia Clínica e Institucional pela Pontifícia Universidade Católica do Rio Grande do Sul/PUCRS.

\section{Amilton Gustavo da Silva Passos}

Licenciado em Biologia pela UFS, Doutorando em Educação no Programa de Pós-Graduação em Educação da UFRGS, linha de pesquisa Educação, Sexualidade e Relações de Gênero.

\section{Cláudio Nunes}

Doutor em Educação, Mestre em Ciências do Movimento Humano, assessor técnico da Área Técnica DST/AIDS e Hepatites Virais da Secretaria Municipal de Saúde/Porto Alegre. Currículo on-line disponível em: < http:// lattes.cnpq.br/691999408598556>.

\section{Denise Dourado Dora}

Ouvidora-Geral da Defensoria Pública do Estado (DPE) do Rio Grande do Sul, para o biênio 2015-2017. Integrante da Ong Themis Gênero e Justiça. 
Doutoranda em Sociologia pela UFRGS. Mestre em Ciências Criminais pela PUCRS. Bacharel em Direito pela FURG. Professora Assistente da Universidade Federal do Rio Grande/FURG. E-mail para contato: elisacelmer@hotmail.com.

\section{Fabiane Simioni}

Doutora em Direito (UFRGS), professora e pesquisadora na Universidade Federal do Rio Grande (FURG). Pesquisadora vinculada à Rede de Estudos Avançados em Direitos Humanos, do Instituto LatinoAmericano de Estudos Avançados (ILEA/UFRGS).

\section{Fernando Seffner (Organizador)}

Professor do Programa de Pós-Graduação em Educação da UFRGS e coordenador da Rede de Estudos Avançados em Direitos Humanos: diferenças culturais e gramáticas do reconhecimento do Instituto LatinoAmericano de Estudos Avançados ILEA/UFRGS.

\section{Paula Pinhal de Carlos}

Professora permanente do Mestrado em Direito e professora colaboradora do Programa de Pós-graduação em Memória Social e Bens Culturais do UNILASALLE. Professora da graduação em Direito do Uniritter. Doutora em Ciências Humanas pela UFSC e Mestra em Direito e Bacharela em Ciências Jurídicas e Sociais pela UNISINOS. 
Doutor em filosofia (UNISINOS), professor de filosofia no Instituto Berthier (IFIBE, Passo Fundo, RS), membro do Grupo de Estudo e Pesquisa sobre Educação em Direitos Humanos, presidente do Conselho Estadual de Direitos Humanos do Rio Grande do Sul.

Renan Bulsing dos Santos (Organizador)

Graduado em Ciências Jurídicas e Sociais pela Universidade Federal de Santa Maria, bacharel em Ciências Sociais e mestre em Antropologia Social pela Universidade Federal do Rio Grande do Sul. Um dos fundadores da Rede de Estudos Avançados em Direitos Humanos do Instituto LatinoAmericano de Estudos Avançados (ILEA) da Universidade Federal do Rio Grande do Sul.

Rochele Fellini Fachinetto (Organizadora)

Professora Adjunta do Departamento de Sociologia e do Programa de Pós-Graduação em Sociologia da UFRGS e coordenadora da edição 2014 do Curso Educação em Direitos Humanos em regime EAD ofertado em parceria com Ministério da Educação/Secretaria de Educação Continuada, Alfabetização, Diversidade e Inclusão/UFRGS. Mestre e Doutora em Sociologia pela UFRGS. Pesquisadora do Grupo de Pesquisa Violência e Cidadania/UFRGS.

\section{Rúbia Aparecida Cidade Borges}

Professora de Geografia na Secretaria de Educação de Porto Alegre, educadora selecionada ao Prêmio Educador Nota 10 da Fundação Victor Civita em 2014. 
